DANIEL GUSTAVO FALCÃO PIMENTEL DOS REIS

\title{
O ATIVISMO JUDICIAL NO BRASIL: O CASO DA VERTICALIZAÇÃO
}

\author{
TESE DE DOUTORADO
}

ORIENTADOR: PROFESSOR ASSOCIADO RUBENS BEÇAK

UNIVERSIDADE DE SÃO PAULO

FACULDADE DE DIREITO

SÃo PAULO

2014 
DANIEL GUSTAVO FALCÃO PIMENTEL DOS REIS

\title{
O ATIVISMO JUDICIAL NO BRASIL: O CASO DA VERTICALIZAÇÃO
}

\author{
Tese de Doutorado apresentada \\ no Programa de Pós-Graduação \\ Stricto Sensu da Faculdade de \\ Direito da Universidade de São \\ Paulo, como requisito parcial \\ para a obtenção do título de \\ Doutor em Direito do Estado, \\ sob a orientação do Professor \\ Associado Rubens Beçak.
}

UNIVERSIDADE DE SÃO PAULO

FACULDADE DE DIREITO

SÃO PAULO

2014 
NOME: Daniel Gustavo Falcão Pimentel dos Reis

Título: O ativismo judicial no Brasil: 0 caso da verticalização

Tese de Doutorado apresentada no Programa de Pós-Graduação Stricto Sensu da Faculdade de Direito da Universidade de São Paulo, como requisito parcial para a obtenção do título de Doutor em Direito do Estado, sob a orientação do Professor Associado Rubens Beçak.

Aprovado em:

BANCA EXAMINADORA

Prof. Associado Rubens Beçak

Julgamento:

Prof. Dr.

Julgamento:

Prof. Dr.

Julgamento:

Prof. Dr.

Julgamento:

Prof. Dr.

Julgamento:
Instituição: Faculdade de Direito da Universidade de São Paulo

Assinatura:

Instituição:

Assinatura:

Instituição:

Assinatura:

Instituição:

Assinatura:

Instituição:

Assinatura: 
Ao meu pai, José Lúcio dos Reis Neto, que nos deixou no meio desta caminhada, restando apenas 0 imenso carinho, os grandes ensinamentos $e$ a eterna saudade. 


\section{AGRADECIMENTOS}

Meu primeiro agradecimento deve ser dirigido ao meu orientador, Professor Rubens Beçak, que, em todo o momento, fez o possível para apoiar esta pesquisa, além de sempre compreender minhas dificuldades em conciliar a Pós-Graduação e minha carreira profissional.

À Professora Monica Herman Salem Caggiano, por seu enorme carinho e generosidade. Tenho muita sorte em ter sido aluno dela na Graduação, no Mestrado, no Doutorado e também na Especialização. Tive o imenso privilégio de tê-la como arguidora nas minhas bancas de qualificação no Mestrado e no Doutorado. Por fim, tive a honra de fazer parte de grupos de estudo sob seu comando, bem como de ter sido convidado por ela a participar de obras publicadas com enfoque nas minhas duas maiores paixões acadêmicas: o Direito Constitucional e o Direito Eleitoral.

Ao Professor Cláudio Lembo, agradeço as lições inesquecíveis aprendidas nas aulas da Pós-Graduação e também na minha banca de qualificação, lições estas tão úteis para a consecução deste trabalho.

À Ministra Nancy Andrighi, pelo carinho, compreensão e pela confiança no meu esforço e escasso talento, que resultaram numa excelente convivência profissional no Superior Tribunal de Justiça e em novas oportunidades profissionais e acadêmicas em Brasília.

À Secretária-Executiva da Secretaria de Assuntos Estratégicos da Presidência da República, Suzana 
Dieckmann Jeolás e Jeolás, por ter me concedido uma oportunidade ímpar de conhecer os meandros do órgão mais importante da República.

Aos meus amigos Érico Pilatti, Hector Rodrigo Ferraz, Maira Yuriko Rocha Miura Pontieri, Eduardo Pontieri, Gláucia Assalin Nogueira, Roberto Gazarini Dutra, Cláudio Castelo de Campos Pereira, Pythagoras Lopes de Carvalho Neto, Gustavo Mathias Alves Pinto, Felippe Nogueira Monteiro e Giacomo Cenci, pela amizade, pelo carinho, pelos momentos bons e pela enorme força nos dias ruins que, infelizmente, a vida por vezes nos traz.

Aos meus amigos Ana Paula Fuliaro, Carolina Dalla Pacce, Alexandre Sanson e Ricardo "Macau" Victalino de Oliveira, não só pela amizade, mas também por dividirem as angústias de um aluno de Pós-Graduação.

Às minhas amigas Karine Barros, Denise Torres Araújo e à minha tia Vânia de Araújo Pereira, por me ajudarem tanto no desafio de encarar a aridez, literal e figurada, de viver na nossa Capital Federal.

Ao meu "Docinho", Ana Carolina Cavalcanti de Albuquerque, por ter me dado tanto carinho e compreensão nessa trajetória tão difícil. Reconheço desde já que sua ajuda, como "provocadora" e revisora, foi essencial para a conclusão deste trabalho. Sem você ao meu lado, ele não existiria.

Ao meu "eterno bebezinho", minha irmãzinha Sarah, por ser minha companhia amiga desde 1988 . 
À minha mãe, Regina, simplesmente por tudo. Minhas parcas qualidades são devidas a você, a melhor mãe do mundo.

Por fim, aproveito o ensejo para homenagear, mesmo que tardiamente, José Lúcio dos Reis Neto. Honesto, trabalhador, generoso, extremamente dedicado à família e aos amigos, Papai nos deixou muito cedo, de modo absolutamente surpreendente. Todos os que conheciam sabiam do quanto ele amava a vida e a aproveitava intensamente, sempre ao lado de quem ele amava. Só nos resta aqui a saudade e o cumprimento de seu legado, recheado de excelentes lições de como devemos fazer para alcançar o sucesso pessoal, familiar e profissional. Deus o levou cedo sim, mas porque quer que ao seu lado fiquem as pessoas de enorme coração e bondade. Era o caso do meu pai. 
"At the same time, the candid citizen must confess that if the policy of the Government upon vital questions affecting the whole people is to be irrevocably fixed by decisions of the supreme court, the instant they are made in ordinary litigation between parties in personal actions the people will have ceased to be their own rulers, having to that extent practically resigned their Government into the hands of that eminent tribunal."

Abraham Lincoln

"[The judiciary is] the least dangerous branch of our government." Alexander M. Bickel 


\section{RESUMO}

REIS, Daniel Gustavo Falcão Pimentel dos. O ativismo judicial no Brasil: o caso da verticalização. 2014. 306 f. Tese (doutorado). Faculdade de Direito da Universidade de São Paulo, São Paulo, 2014.

Desde a promulgação da atual Constituição da República Federativa do Brasil, em cinco de outubro de 1988, percebese que o fenômeno do ativismo judicial tem ganhado força nos Tribunais brasileiros nos mais variados assuntos, entre eles o direito político-eleitoral. Este trabalho visa a evidenciar este fenômeno no Brasil, mais precisamente por meio do estudo pormenorizado do caso da verticalização das coligações partidárias. A atuação do Tribunal Superior Eleitoral, em fevereiro de 2002, a respeito da verticalização provocou o debate sobre o ativismo judicial na Imprensa, no Congresso Nacional e também entre juristas e cientistas políticos. A manutenção da interpretação do TSE pelo Supremo Tribunal Federal, por duas vezes, só veio a arregimentar ainda mais discussões sobre o tema. Houve movimentação por parte do Legislativo e de Partidos Políticos no sentido de extirpar definitivamente tal interpretação judicial do ordenamento jurídico brasileiro. Assim sendo, este trabalho compõe-se de análises sobre decisões de tribunais superiores (TSE e STF) em que o fenômeno do ativismo judicial foi identificado. De modo a contextualizar dogmaticamente a análise das decisões, serão abordados aspectos constitucionais e legais concernentes à Justiça Eleitoral, demonstrando como as decisões sobre a verticalização ultrapassaram a competência judicial sobre a matéria. Para contextualizar as decisões analisadas na jurisprudência dos tribunais superiores, serão retomados os julgamentos proferidos pelo Tribunal Superior Eleitoral e pelo Supremo Tribunal Federal em fidelidade partidária, regras de propaganda eleitoral, requisitos de elegibilidade (certidão de quitação eleitoral) e número de vereadores em cada município brasileiro. Por fim, a análise das decisões dos tribunais superiores a respeito da verticalização será contraposta aos limites legais e constitucionais previamente estudados, evidenciando, assim, o fenômeno do ativismo judicial no direito eleitoral.

Palavras-chave: Ativismo Judicial, Verticalização, Coligações Partidárias, Tribunal Superior Eleitoral, Supremo Tribunal Federal, Partido Político, Campanha Eleitoral. 


\section{ABSTRACT}

REIS, Daniel Gustavo Falcão Pimentel dos. The judicial activism in Brazil: the verticalization case. 2014. 306 f. Tese (doutorado). Faculdade de Direito da Universidade de São Paulo, São Paulo, 2014.

Since the promulgation of the Constitution of the Federative Republic of Brazil, in October 5, 1988, the (phenomenon known as) judicial activism has built-up in strength on the Brazilian courts, being discussed in many cases, including those related to Election Law. This thesis intends to demonstrate this phenomenon occurrence in Brazil, more specifically by studying the case of vertical party coalitions. The performance of the Superior Electoral Court concerning the verticalization, in February 2002, raised the debate on judicial activism on the press, the Congress and also among jurists and political scientists. The preservation of the Superior Electoral Court's interpretation by the Supreme Federal Court has raised even more debates on the subject. Furthermore, the Legislative Power and some political parties also tried to exclude this judicial interpretation from the Brazilian legal system. Thus, this thesis consists on the analysis of superior courts' decisions in which the phenomenon has occurred. Focusing on the its dogmatic contextualization, constitutional and legal aspects of the Electoral Justice will be discussed, demonstrating how the decisions on verticalization exceed the jurisdiction on that matter. To contextualize the decisions with the superior courts' jurisprudence, the rulings of supreme Federal Court and the Superior Electoral Court on party loyalty, campaign advertising, elegibility, and the maximum number of deputies in each Brazilian municipality will be examined. Finally, the analysis of the superior courts' decisions concerning the verticalization will be faced in opposition to the legal and constitutional limits previously examined, demonstrating the existence of the judicial activism phenomenon on the Election Law.

Keywords: Judicial Activism, Verticalization, Party Coalitions, the Superior Electoral Court, The Supreme Federal Court, Political Parties, Political Campaign. 


\section{RIASSUNTO}

REIS, Daniel Gustavo Falcão Pimentel dos. L'attivismo giudiziario in Brasile: il caso dela verticalizzazione. 2014. 306 f. Tese (doutorado). Faculdade de Direito da Universidade de São Paulo, São Paulo, 2014

Sin dalla promulgazione dell'attuale Costituzione della Repubblica Federale del Brasile, il 5 ottobre 1988, si costata come il fenomeno dell'attivismo giudiziario abbia guadagnato forza nei Tribunali brasiliani nelle più diverse aree, tra le quali quella del diritto elettorale. Il presente elaborato si propone di mettere in luce questo fenomeno in Brasile, in special modo tramite lo studio dettagliato della verticalizzazione delle coalizioni tra partiti. L'azione del Tribunale Superiore Elettorale riguardo alla verticalizzazione, nel febbraio del 2002, ha provocato un dibattito sull'attivismo giudiziario nei mass media, nel Congresso Nazionale e tra giuristi e politologi. La conferma, da parte del supremo Tribunale Federale, dell'interpretazione del TSE, per ben due volte, ha sollevato ulteriori discussioni sul tema. Vi è stata una movimentazione da parte del potere legislativo e dei partiti politici al fine di estirpare definitivamente tale interpretazione giurisprudenziale dall'ordinamento giuridico brasiliano. Di fronte a questo quadro, il presente elaborato è composto dall'analisi delle decisioni dei tribunali superiori (TSE e STF) in cui si è colto il fenomeno dell'attivismo giudiziario. Al fine di contestualizzare dogmaticamente l'analisi delle decisioni, saranno trattati aspetti costituzionali e legali concernenti la Giustizia Elettorale, dimostrando come le decisioni sulla verticalizzazione hanno violato la competenza giurisdizionale in materia. Allo scopo di contestualizzare le decisioni analizzate all'interno della giurisprudenza dei tribunali superiori, saranno riprese le sentenze emesse dal Tribunale Superiore Elettorale e dal Supremo Tribunale Federale a riguardo della fedeltà partitica, delle norme che regolano la campagna elettorale, dei requisiti di eleggibilità (certificato di "quitação eleitoral") e del numero di consiglieri municipali in ogni comune brasiliano. Infine, l'analisi delle decisioni dei tribunali superiori sulla verticalizzazione verrà contrapposta ai limiti legali e costiturionali studiati in precedenza, evidenziando, in questo modo, il fenomeno dell'attivismo giudiziario nell'ambito del diritto elettorale.

Parole chiave: attivismo giudiziario, verticalizuazione, coalizioni parttitiche, Tribunale superiore Elettorale, Supremo Tribunale Federale, Partito Politico, Campagna Elettorale. 


\section{SIGLÁRIO}

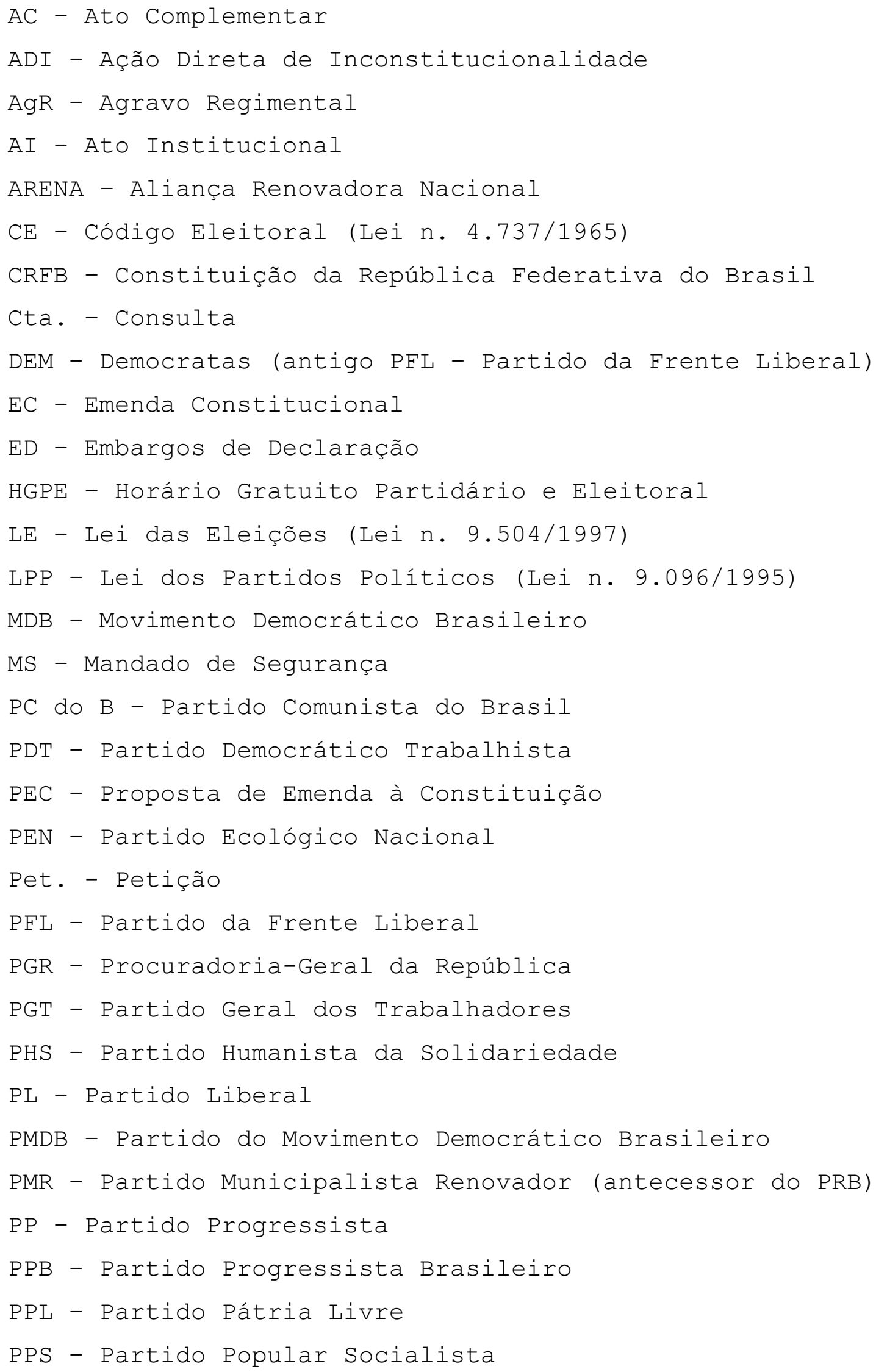




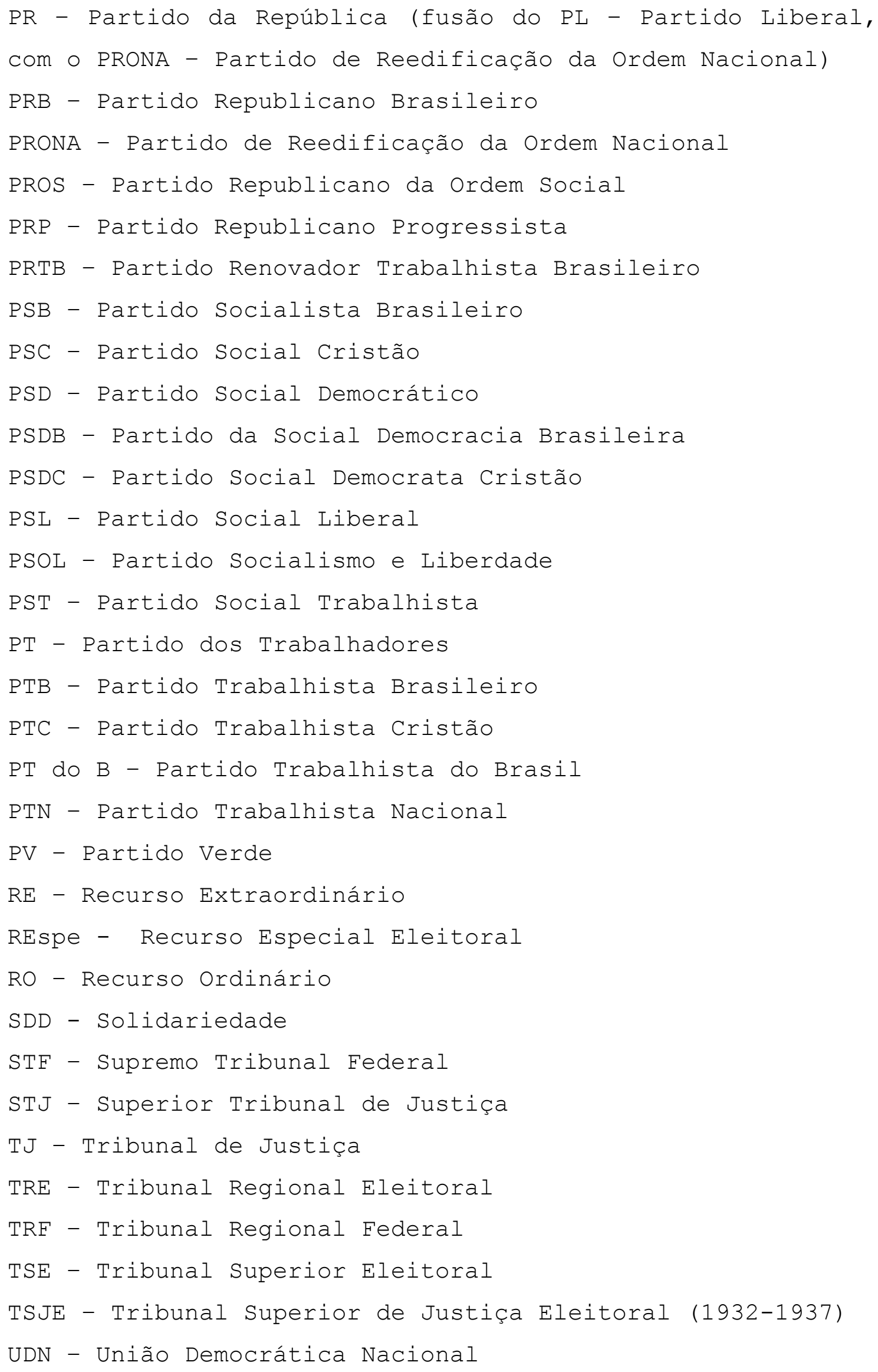




\section{SUMÁRIO}

1. INTRODUÇ̃̃o . . . . . . . . . . . . . . . . . . . 17

1.1. Verticalização: um caso de ativismo judicial .... 17

1.2. Coligações no sistema partidário brasileiro. .... 22

1.3. Síntese sobre o caso da verticalização .......... 28

1.4. Contribuição original à ciência jurídica brasileira

1.5. Método de estudo e de análise de decisões.......40

2. O Fenômeno do Ativismo Judicial no Brasil.........42

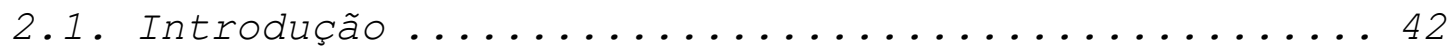

2.2. Histórico do fenômeno. Conceituação de ativismo

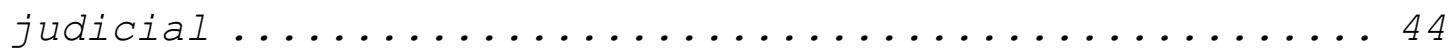

2.3: Ativismo judicial e Judicialização da Política. . 52

2.4. Causas do surgimento do fenômeno do ativismo

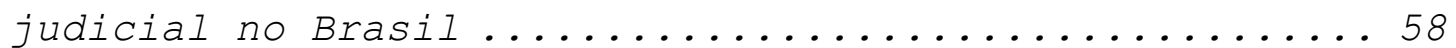

2.5. Ativismo judicial: análise de casos .......... 62

2.5.1. Proibição do uso de imagens externas na

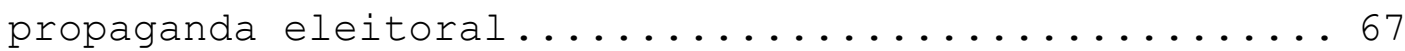

2.5.2. Proporcionalidade entre o número de cadeiras nas

Câmaras Municipais e a população do Município....... 75

3. JUSTIÇA ELEITORAL BRASILEIRA.............. 93

3.1. Evolução Constitucional ................... 94

3.2. Constituição de 1988: órgãos e competência

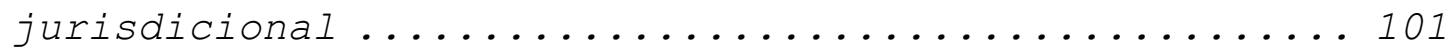

3.3. Competências Consultiva e Regulamentar: o art. 23, incisos IX e XII, do Código Eleitoral .............. 112 3.4. O fenômeno do ativismo judicial e a implantação da reforma política pelo Poder Judiciário ........................... 17

3.4.1. Fidelidade Partidária (2007) ............. 120

3.4.2. Conceito de quitação eleitoral (2008 e 2012) . 156

4. Caso concreto: a Verticalização das coligações

partidárias ........................... 174

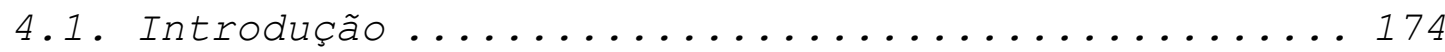


4.2. Regime normativo das coligações partidárias no

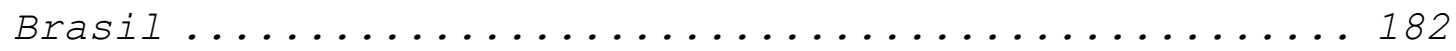

4.2.1. Lei das Eleições (Lei n. 9.504/97) ......... 182

4.2.2. Resolução n. $20.126 / 98$ do TSE (Consulta n. 382)

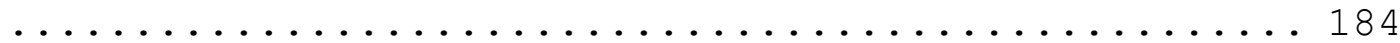

4.3. Resolução 21.002 do TSE (Consulta n. 715): criação

interpretativa da Verticalização ................ 190

4.3.1. Argumentos pró-verticalização............. 191

4.3.1.1. Caráter nacional dos partidos políticos .. 192

4.3.1.2. Assimetria das Coligações ............ 196

4.3.1.3. Conceito de "parâmetro inafastável" e a

Teoria dos Conjuntos Circunscricionais ......... 197

4.3.1.4. Incoerência no Horário Eleitoral Gratuito 200

4.3.1.5. Possíveis Benesses da Verticalização ao

Sistema Político-Eleitoral Brasileiro .......... 202

4.3.2. Argumentos contra a verticalização......... 203

4.3.2.1. Conceito de Circunscrição Eleitoral ..... 203

4.3.2.2. Princípio da Anterioridade Eleitoral .... 205

4.3.2.3. Autonomia constitucional dos Partidos

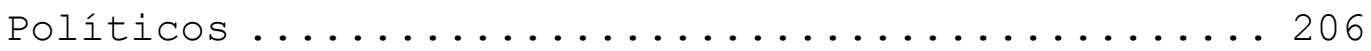

4.4. Consultas formuladas ao Tribunal Superior Eleitoral

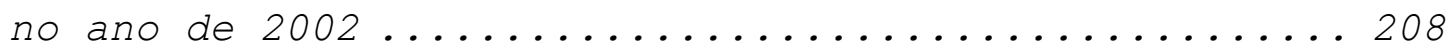

4.4.1 "Afrouxamento" da Verticalização: Resoluções TSE

n. 21.045, 21.046, 21.047, 21.048 e 21.049.......209

4.5. Ações Diretas de Inconstitucionalidade n. $2.626 \mathrm{e}$

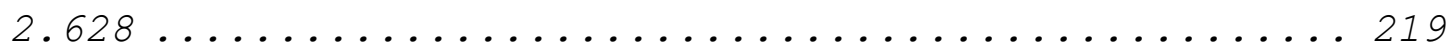

4.5.1. Inexistência do controle de constitucionalidade concentrado da função normativa/regulamentar da Justiça

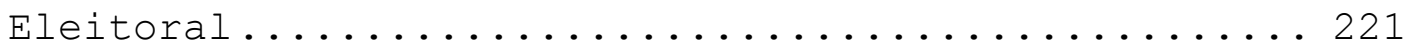

4.5.2. Argumentação contrária à Verticalização..... 225

4.6. Reação Legislativa: a Proposta de Emenda

Constitucional n. $548 / 2002 \ldots \ldots \ldots \ldots \ldots \ldots \ldots \ldots \ldots$

4.7. Consultas formuladas ao Tribunal Superior Eleitoral

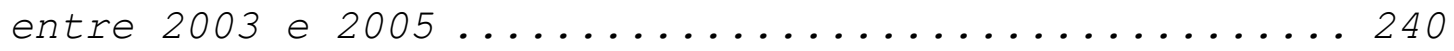

4.8. Resolução n. 22.161 do TSE (Consulta n. 1.185): a

confirmação da Verticalização para as eleições de 2006243

4.9. Ação Direta de Inconstitucionalidade n. 3.685 ... 249

4.9.1. Princípio da Anterioridade Eleitoral....... 250

4.9.2. Argumentação contrária à Verticalização..... 261

4.10. Consultas formuladas ao Tribunal Superior Eleitoral

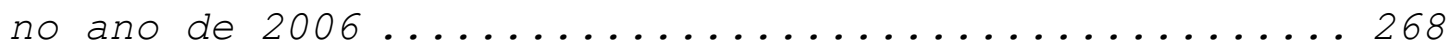


4.10.1. "Enrijecimento" da Verticalização: a Resolução

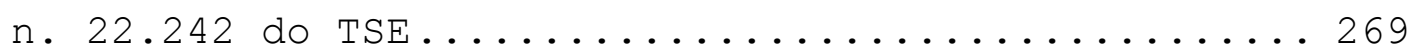

4.10.2. Novo "afrouxamento" da Verticalização: as

Resoluções n. 22.244 e 22.248 do TSE.............273

4.11. Resolução n. 23.200 do TSE (Consulta n. 1.735): o

reconhecimento do fim da Verticalização .......... 277

4.12. Análise das decisões sobre a verticalização das

coligações partidárias sob a ótica do fenômeno do

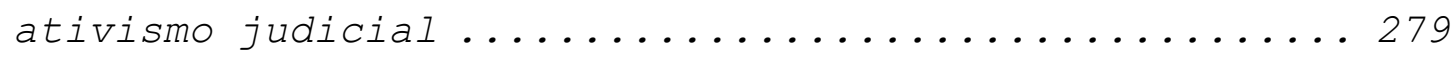

5. Considerações finais ................... 288

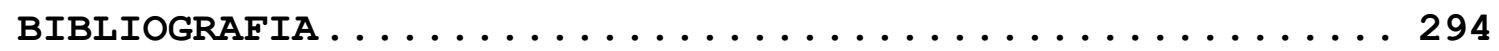




\section{INTRODUÇÃO}

\subsection{Verticalização: um caso de ativismo judicial}

A legislação político-eleitoral

brasileira caracterizava-se pelo pouco tempo de vigência. Um ano antes de cada eleição, o Congresso Nacional se incumbia de aprovar uma nova lei com o objetivo de reger as eleições seguintes, fazendo com que a cada dois anos o país tivesse uma nova regulamentação do processo eleitoral ${ }^{1}$.

A notória instabilidade normativa no campo político-eleitoral do Brasil ${ }^{2}$ começou a se encerrar na década de 1990. A promulgação da Lei dos Partidos Políticos (Lei n. 9.096) e, em 1997, a entrada em vigor da Lei das Eleições (Lei n. 9.504), produzida pelo Congresso, e concebida para ser a lei definitiva sobre o processo eleitoral brasileiro modificaram esse contexto histórico ${ }^{3}$.

Mesmo com a vigência da Lei das Eleições desde o pleito de 1998, o tema da reforma política

\footnotetext{
1 VIEIRA, Tarcisio. "Experiencias nacionales representativas: Brasil". In: ZovATTO, Daniel et.all (coord.). Dinero y contienda politicoelectoral: reto de la democracia. México: Fondo de Cultura Económica, 2003, p. 426.

2 Luiz Carlos dos Santos Gonçalves classifica a legislação eleitoral como "caótica". O autor usa o Código Eleitoral (Lei 4.737/65) como exemplo: "O Código Eleitoral (CE) de 1965, que regulamentou as eleições num momento de ausência de democracia, trai sua origem no excessivo detalhamento e em seu furor organizatório e sancionatório. (...) É um diploma no qual as diversas funções da Justiça Eleitoral administrativa, normativa e judicial - são confundidas e misturadas, sem método nem aviso". ("Sugestões para a reforma do direito eleitoral", In: Revista do Advogado, ano XXX, n. 109, agosto de 2010, p. 62 ).

${ }^{3}$ A evolução histórica da legislação político-eleitoral brasileira pode ser conferida em artigo assinado por Cláudio Lembo: "Cronologia básica do direito eleitoral brasileiro". In: CAGGIANO, Monica Herman Salem; LEMBO, Cláudio (coords.). O voto nas Américas. Barueri: Manole, 2008, p. $73-106$.
} 
continuou na pauta do Legislativo do Poder Executivo, perseverando também como uma das principais preocupações dos estudiosos e dos agentes políticos brasileiros.

$\mathrm{Na}$ verdade, desde a promulgação da Constituição Federal de 1988, discute-se tanto no Congresso como nos meios acadêmicos qual seria a melhor fórmula para reformar o sistema político-eleitoral brasileiro ${ }^{4}$.

Há diversas propostas apresentadas no Congresso Nacional e também nos meios acadêmicos. Entre essas mudanças propostas, destacam-se a fidelidade partidária; a adoção da cláusula de desempenho (ou de barreiral; alterações no sistema proporcional; ajustes nas regras do financiamento da política, apontado por muitos como a verdadeira panaceia ${ }^{5}$ da reforma política e, por fim, alterações no sistema partidário brasileiro. Na prática, a Lei das Eleições e a Lei dos Partidos Políticos sofreram apenas mudanças pontuais.

Nesse contexto, pôde-se observar nestes últimos anos um interessante fenômeno que será o foco

\footnotetext{
4 É imperioso reconhecer o avanço institucional que o Brasil sofreu desde a promulgação da Constituição de 1988. Mesmo havendo crises econômicas, sociais e políticas graves neste período, houve avanços notáveis nestes mesmos campos. A questão da reforma política é premente, mas não deve-se reconhecer que, diante do espectro do período militar, o Estado Democrático de Direito vem prevalecendo. Corrobora com esta análise Luís Roberto Barroso, que declara: "A Constituição de 1988 foi o rito de passagem para a maturidade institucional brasileira. Nos últimos vinte anos, superamos todos os ciclos do atraso: eleições periódicas, Presidentes cumprindo seus mandatos ou sendo substituídos na forma constitucionalmente prevista, Congresso Nacional em funcionamento sem interrupções, Judiciário atuante e Forças Armadas fora da política. Só quem não soube sombra não reconhece a luz". "Vinte anos da constituição de 1988: a reconstrução democrática do Brasil". In: Revista de Informação Legislativa, ano 45, n. 179, jul./set. 2008, p. 30 .

5 ROdRIGUES, Fernando. Políticos do Brasil. São Paulo: Publifolha, 2006 . p. 159 .
} 
desse trabalho: algumas das principais mudanças ocorridas no ordenamento jurídico brasileiro, no que concerne ao sistema partidário-eleitoral, foram promovidas não pelo Poder Legislativo, mas sim pelo Poder Judiciário.

O Tribunal Superior Eleitoral (TSE) e o Supremo Tribunal Federal (STF) já decidiram diversas questões no âmbito do sistema partidário-eleitoral brasileiro em toda sua história e, após a Constituição de 1988, os dois tribunais continuaram a se debruçar sobre assuntos ligados ao tema.

Pode-se destacar, entre outras decisões, (i) o acórdão que vetou a existência de candidaturas natas no ordenamento jurídico brasileiro; (ii) a decisão que determinou pormenorizadamente o número de vereadores em cada município brasileiro em respeito ao respectivo número de eleitores; (iii) a determinação de que o mandato, proporcional ou majoritário, pertence ao partido político e não ao candidato eleito, o que diminuiu a frequência do fenômeno conhecido como "infidelidade partidária"; (iv) a inconstitucionalidade da cláusula de barreira prevista na Lei dos Partidos Políticos; e (v) a aplicação do princípio da coerência das coligações partidárias (verticalização) .

Este trabalho se propõe a analisar com profundidade as decisões a respeito da verticalização das coligações partidárias. Essa decisão, exarada pelo Judiciário, alterou intensamente o sistema políticopartidário com relação à liberdade e à autonomia dos partidos políticos. Cabe ressaltar também que a Consulta sobre a verticalização das coligações, decidida no início de 2002, foi um verdadeiro leading case do novo papel da Justiça Eleitoral e, por consequência, também o STF, 
quanto ao tratamento dos casos abstratos trazidos à sua apreciação .

Ao pronunciar-se sobre a verticalização, - Tribunal Superior Eleitoral (TSE), em decisão posteriormente confirmada pelo Supremo Tribunal Federal (STF), trouxe uma nova interpretação ao funcionamento das coligações partidárias nas eleições gerais brasileiras (distritais, estaduais e nacional).

A nova regra, que ficou popularmente conhecida como verticalização, consistia na vigência do princípio da coerência das coligações partidárias. Os partidos coligados na eleição nacional (presidência da República) não poderiam se coligar com nenhuma agremiação adversária na corrida ao Planalto nas eleições estaduais.

A verticalização vigeu nas eleições gerais de 2002 e 2006, sendo uma regra determinante para o "quebra-cabeça" partidário nestes escrutínios, visto que mudou completamente as regras até então vigentes para a formação de alianças partidárias no âmbito nacional e estadual.

O fato de O TSE e O STF se debruçarem frequentemente sobre questões fulcrais do direito político-eleitoral brasileiro demonstra que a análise destas decisões deve ser feita sob uma diferente perspectiva: o fenômeno do ativismo judicial.

$$
\text { Este fenômeno está cada vez mais }
$$
presente nos países democráticos, e no Brasil não é diferente. Diariamente, pode-se perceber a prolação de decisões judiciais nas quais os magistrados são acusados 
de extrapolarem os limites legais e constitucionais impostos às suas funções. Nota-se esse fenômeno em litígios envolvendo questões materiais envolvendo saúde, educação e adoção de políticas públicas. Na seara política-eleitoral, o fenômeno também pode ser percebido.

Esta tese irá demonstrar, conforme se poderá ver a seguir, um caso de ativismo judicial. O TSE, quando da apreciação da verticalização, exacerbou em sua função normativa/regulamentar prevista no art. 23, IX, do Código Eleitoral e, na prática, legislou sobre o tema. A exacerbação cometida pelo TSE foi referendada pelo STF por duas vezes.

Diante deste quadro, este trabalho conterá o estudo do fenômeno chamado ativismo judicial no Brasil. O tema escolhido nos força a lidar com uma especificidade da Justiça Eleitoral. A ela foi conferida a peculiaridade de ser o único ramo judiciário brasileiro com competência de regulamentar as normas legislativas eleitorais brasileiras, exercendo essa função regulamentar também por meio de consultas formuladas por autoridades federais como, por exemplo, parlamentares federais e dirigentes partidários. No uso de sua competência regulamentar, a Justiça Eleitoral também se excede e, por consequência, enfraquece o Poder Legislativo.

Este trabalho focará os julgamentos concernentes à questão da verticalização das coligações partidárias. A avaliação dos casos estudados não pode ser feita sem que se leve em consideração o contexto político das alianças partidárias no Brasil. Assim sendo, é necessário que se trace um rápido panorama da sistemática partidária no Brasil. 


\subsection{Coligações no sistema partidário brasileiro.}

Os partidos políticos, indubitavelmente, são instituições de grande relevo. Não só na sociedade brasileira, mas também têm destaque no texto constitucional vigente no ordenamento jurídico brasileiro, visto que há um capítulo exclusivo para eles na Constituição.

A principal função do partido político em um Estado democrático de direito como o brasileiro é, segundo Gilmar Mendes, exercer uma função de mediação entre o povo e o Estado no processo de formação da vontade política, especialmente no que concerne ao processo eleitoral ${ }^{6}$.

Nas palavras de José Afonso da Silva, o partido político "é uma forma de agremiação de um grupo social que se propõe organizar, coordenar e instrumentar a vontade popular com o fim de assumir o poder para realizar seu programa de governo ${ }^{7 \prime \prime}$.

Diante de tamanha importância, o sistema partidário brasileiro também se tornou alvo de debates tanto no meio acadêmico como no meio político, alvo este incluído no tema da reforma política onipresente no Congresso Nacional e também nas campanhas presidenciais de 2010 .

Quanto à avaliação do sistema partidário brasileiro atual, há na doutrina duas posições antagônicas. A primeira, mais tradicional, é a de que os

6 Cf. MENDES, Gilmar; BRANCO, Paulo Gustavo Gonet. Curso de direito constitucional. São Paulo: Saraiva, $8^{a}$ ed. rev. e atual, 2013, p. 764. 7 AFONSO DA SILVA, José. Curso de direito constitucional positivo. São Paulo: Malheiros, $33^{\mathrm{a}} \mathrm{ed}$. rev. e atual., 2010, p. 394. 
partidos no Brasil são muito frágeis, pouco desenvolvidos, possuem vida efêmera na maior parte das vezes e mantêm laços muito fracos com a sociedade. Scott Mainwaring pondera que em comparação com o nível brasileiro de desenvolvimento econômico, o Brasil é um caso único de subdesenvolvimento partidário no mundo ${ }^{8}$.

Essa alegada fragilidade teria como base, em primeiro lugar, o fato de que antes do regime militar, os partidos políticos já não eram fortes. Graças às radicais mudanças sofridas nos sistemas partidários brasileiros ${ }^{9}$, não foram criados os laços fortes entre as agremiações e a sociedade; tanto que, nos últimos anos do regime militar, após o início da distensão política iniciada pelo General Ernesto Geisel (1974-1979), houve a criação de vários novos partidos, sendo que nenhum deles tinha qualquer vinculação com aqueles existentes no período democrático de 1945 a $1964^{10}$.

Ademais, conforme avaliação dessa primeira corrente, o personalismo impera nas agremiações partidárias. Com estruturas internas pouco democráticas, os partidos muitas vezes são dominados por pequenos grupos

\footnotetext{
8 MAINWARING, Scott. "Brazil: weak parties, feckless democracy". In: MAINWARING, Scott; SCULLY, Timothy R.. Building democratic institutions: party systems in Latin America. Stanford: Stanford University Press, 1995, p. 354.

9 No Império (1822-1889), vigia o sistema bipartidário. Até o advento do Estado Novo (1937), o período republicano caracterizou-se pela inexistência de um partido de caráter nacional, existindo então somente partidos regionais. Entre 1937 e 1945, era vedada a existência de partidos e o Congresso Nacional permaneceu fechado. Já no período democrático de 1945 a 1964, existiu um multipartidarismo, com destaque à UDN, ao PTB e ao PSD. Por fim, no Regime Militar (1964-1985), na maior parte do tempo houve um sistema bipartidário, que redundou na redemocratização em um novo sistema multipartidário.

10 Em outros países da América Latina, diferentemente do Brasil, após o fim dos regimes militares, os sistemas partidários democráticos eram cópias dos sistemas vigentes antes dos golpes, ou seja, os partidos que foram extintos pelos militares foram refundados, com as mesmas denominações, características e ideologia.
} 
que tomam as decisões em conformidade com os seus interesses políticos pessoais.

Assim, os partidos, muitas vezes, são classificados, por essa corrente, como pragmáticos e personalistas. Pragmáticos, porque fazem alianças pensando somente em ganhos político-eleitorais, deixando de lado características ideológicas. Personalistas, porque seus líderes dominam a estrutura interna, deixando pouco espaço para as vozes dissonantes. Não só os acadêmicos, mas também a sociedade em geral avaliam os partidos políticos desse modo.

Esse diagnóstico é ainda mais acentuado pelas regras do sistema eleitoral brasileiro. Em uma campanha proporcional (Câmara dos Deputados, Assembleias Legislativas e Câmaras Municipais), os partidos, na verdade, possuem dupla finalidade: (i) dar o status de elegibilidade ao candidato ${ }^{11}$; (ii) ceder algum tempo no rádio e na televisão ao candidato.

Neste contexto, as campanhas têm um caráter individual. Os candidatos lutam sozinhos por votos e arrecadam dinheiro para suas campanhas também individualmente ${ }^{12}$. Maria D'Alva Gil Kinzo corrobora com essa opinião, defendendo que o quadro partidário

11 Como para ser candidato (e possivelmente ser eleito) o cidadão deve ser obrigatoriamente filiado a um partido político, ao menos neste momento a agremiação tem alguma força perante os candidatos, já que sem a legenda (portanto, sem a aprovação de seu nome na Convenção partidária, ele não poderá concorrer a qualquer cargo público.

12 As campanhas para os cargos proporcionais são individuais no Brasil principalmente, conforme já visto anteriormente, pelo fato de que o sistema configura como principais adversários de um postulante os seus companheiros de partido ou coligação. Assim, evidentemente que quase nenhum candidato terá o interesse de gastar seus parcos recursos ou seu curto tempo de campanha ajudando outro companheiro de partido. A estrutura de campanha também é individual, autônoma. É o candidato e seus assessores que controlam os recursos e as aplicações destes, com raríssima influência da máquina partidária. 
caracteriza-se por sua mutabilidade, fragilidade e fragmentação, no qual a existência de muitas agremiações com representação na Câmara dos Deputados, e a constante migração de parlamentares de um partido para outro são sintomas dessa fraqueza partidária brasileira ${ }^{13}$.

A segunda corrente de estudos avalia o sistema partidário brasileiro de modo oposto, menos pessimista. Carlos Ranulfo Melo, por exemplo, assevera que um dos fatores para que o sistema partidário brasileiro seja tão fragmentado decorra do fato de que o federalismo brasileiro enseja o desenvolvimento de partidos médios (fortes em alguns estados, praticamente inexistentes em outros). Estes partidos, ao chegarem ao Congresso Nacional, têm certa relevância no processo decisório, dificultando a governabilidade.

As eleições presidenciais ocorridas em 1994, 1998, 2002 e 2006, segundo Ranulfo Melo, estruturaram o sistema partidário em torno de dois pontos de referência. O primeiro, situado mais à esquerda, liderado pelo PT; o outro, mais à direita, caracterizado pela aliança $\mathrm{PSDB} / \mathrm{DEM}^{14}$.

Esta polarização nas eleições presidenciais foi positiva para o fortalecimento dos partidos, pois como a legislação brasileira proíbe a existência de candidaturas independentes (ou seja, só será candidato quem for filiado a algum partido), desde 1989

13 Cf. KINZO, Maria D'Alva Gil. Radiografia do quadro partidário brasileiro. Rio de Janeiro: Fundação Konrad Adenauer, 1993, p. 25.

14 Kinzo, ao contrário, crê que os partidos apresentam um baixo grau de institucionalização, eis que constatou que são escassas as informações que os partidos detêm sobre sua própria estrutura organizativa, além de uma notória dificuldade deles em serem bem organizados em todos os entes da federação, diante do imenso território brasileiro. 
não houve qualquer outsider com chance de vitória rumo ao Planalto.

Os partidos assumiram o controle das disputas, fazendo com que políticos de caráter notoriamente apartidário tenham que se submeter aos partidos ${ }^{15}$.

Este fato é novidade na América Latina. Em outros países, mesmo aqueles com sistemas partidários mais enraizados na sociedade, pode-se perceber que lideranças carismáticas passam por cima de seus partidos e implantam políticas que desestruturam o sistema partidário, como ocorreu na Venezuela de Hugo Chávez e na Argentina pós-Néstor Kirchner.

No Brasil, os partidos controlam cada vez mais o processo decisório congressual por meio do Colégio de Líderes, neutralizando assim a tendência de legisladores atuarem de modo apenas personalista. O acesso ao Fundo Partidário e ao Horário Eleitoral Gratuito também fortaleceu os partidos.

Apesar da evolução, Ranulfo Melo detecta também a continuidade de coligações eleitorais e políticas no Congresso sem quaisquer motivações ideológicas, como os

15 Jairo Nicolau menciona outros aspectos importantes sobre o fortalecimento dos partidos com as eleições presidenciais, especialmente sobre o PT e O PSDB. Além dos dois terem sido os únicos a lançarem candidatos em todas as eleições desde o fim do Regime Militar, Nicolau afirma que em cada eleição os partidos são obrigados a mobilizarem seus técnicos para a elaboração de um programa de governo, tarefa esta que tem como consequência a necessidade de que o partido seja obrigado a apresentar uma convergência mínima em termos programáticos, o que fez como que estes dois partidos se tornassem os mais programáticos entre os maiores partidos brasileiros (Jairo Nicolau. "Notas sobre as eleições de 2002 e o sistema partidário brasileiro". In: HOFMEISTER, Wilhelm (org.). Cadernos Adenauer: eleições e partidos. Ano IV, n. 01, 2003, p. 15). 
vários partidos conservadores que apoiaram o governo Lula e continuar a apoiar o governo petista de Dilma Rousseff.

Ademais, dificuldades assolam todas as grandes siglas. A fragilidade do PT pós-mensalão, do DEM pós-2002 (houve o falecimento de seu principal líder, além da posterior troca de nomenclatura), do PSDB (que não encontrou, na prática, seu espaço no espectro político brasileiro na oposição ao governo federal) e do PMDB (que está cada vez mais forte, mas não tem um nome capaz de concorrer ao Planalto, restando somente aliar-se ao PT ou ao PSDB) é patente ${ }^{16}$.

Diante desse quadro, a decisão que trouxe à baila a verticalização embaralhou ainda mais o cenário partidário brasileiro. Em fevereiro de 2002, em pleno período pré-eleitoral, com as candidaturas presidenciais e para governador de Estado sendo debatidas e apresentadas, O TSE deu nova interpretação às possibilidades de coligações partidárias, restringindo-as de forma abrupta.

Assim sendo, a análise do sistema partidário brasileiro é fundamental para se entender todo o contexto que gerou a interpretação do TSE que criou a verticalização.

16 Cf. MELo, Carlos Ranulfo. "Nem tanto ao mar, nem tanto a terra: elementos para uma análise do sistema partidário brasileiro". In: MELO, Carlos Ranulfo; SAEZ, Manuel Alcántara(orgs.). A democracia brasileira: balanços e perspectivas para o século 21 . Belo Horizonte: Editora UFMG, 2007, pp. 267-302. 


\subsection{Síntese sobre o caso da verticalização}

Feito o exame sobre o sistema partidário brasileiro, passa-se a explicar brevemente o histórico do caso da verticalização. O estudo das decisões exaradas pelo STF e pelo TSE sobre o tema servirá para demonstrar a atuação ativista por parte destas Cortes. Referidas decisões alteraram profundamente 0 quadro partidárioeleitoral brasileiro nas eleições gerais de 2002 e 2006. Explicaremos brevemente o caso.

o conjunto de decisões a ser analisado trata da vigência do princípio da coerência das alianças partidárias, conhecida popularmente como "verticalização". Tal princípio veio à tona após decisão do TSE tomada em sede de Consulta realizada por deputados federais do Partido Democrático Trabalhista (PDT) e depois confirmada pela Suprema Corte.

A verticalização consistiu na obrigação de um partido participante de coligação em âmbito nacional (ou seja, eleição para a presidência da República) não formar aliança em nenhuma eleição estadual com outra agremiação que fosse sua adversária na eleição nacional.

Para um melhor entendimento, basta usar como exemplo as coligações formadas nas eleições gerais de 2002: O PT coligou-se com o então PL para eleger Luiz Inácio Lula da Silva para à Presidência. Assim, tanto O PT como O PL poderiam coligar-se nos estados ou lançar candidaturas próprias aos respectivos governos estaduais, mas jamais formarem aliança com o PSDB ou com o PMDB, que se coligaram na tentativa de eleger José Serra ao cargo de chefe do Poder Executivo Federal. 
No entanto, caso um partido decidisse não participar da eleição nacional (ou seja, a agremiação não lançasse candidatura própria ou participasse de qualquer coligação), este partido estaria livre para formar alianças com quaisquer partidos em qualquer estado. Foi o que ocorreu com o antigo PFL (hoje Democratas) em 2002 e com o PMDB na eleição de 2006.

o principal objetivo da verticalização, na ótica dos Ministros do TSE, em fevereiro de 2002, era enfatizar o caráter nacional dos partidos políticos, impedindo que as agremiações fizessem coligações consideradas incoerentes em comparação à aliança formada no âmbito nacional ${ }^{17}$.

Contudo, mesmo com o ajuizamento de ações diretas de inconstitucionalidade no Supremo Tribunal Federal $(\mathrm{STF})^{18}$ e com uma Proposta de Emenda Constitucional (PEC) com o escopo de acabar com esse princípio, a verticalização vigeu no pleito de 2002 .

Em 2005 houve uma tentativa parlamentar de reagir à decisão da Justiça Eleitoral, sob a forma de votação da Proposta de Emenda Constitucional n ${ }^{\circ} 548$, de 2002 (PEC n. 548/2002). Apesar da intensa pressão dos partidos e dos próprios congressistas, a PEC que revogava a interpretação do TSE sobre a verticalização não foi aprovada até tempo limite previsto no art. 16 da

\footnotetext{
17 Cf. REIS, Daniel Gustavo Falcão Pimentel dos. Verticalização das coligações partidárias: melhor caminho para a coerência políticoeleitoral? Disponível em: http://www.sbdp.org.br/artigos_ver.php?idConteudo=42. Acesso em 11 . 10. 2010 .

18 ADI n. 2.626/DF, rel. Min. Sydney Sanches, rel. para acórdão Min. Ellen Gracie, j. 18.04.2002; ADI n. 2.628/DF, rel. Min. Sydney Sanches, rel. para acórdão Min. Ellen Gracie, j. 18.04.2002.
} 
Constituição para que a norma tivesse eficácia já nas eleições de outubro de 2006.

Em fevereiro de 2006, após nova consulta ${ }^{19}$, O TSE reafirmou que a verticalização continuava a viger. Em seguida da decisão do tribunal eleitoral, o Congresso Nacional, promulgou a PEC proposta em 2002 e aprovada definitivamente poucos dias antes. A PEC n. 548/2002 tornou-se a Emenda Constitucional nº 52 (EC n. 52/2006), promulgada em oito de março, com a pretensão de retirar a "verticalização" do sistema jurídico brasileiro já nas eleições que ocorreram em outubro de 2006.

O Conselho Federal da Ordem dos Advogados do Brasil, inconformado com a promulgação da nova norma constitucional, promoveu ação direta de inconstitucionalidade perante $0 \mathrm{STF}^{20}$, alegando desrespeito ao princípio constitucional da anualidade eleitoral. o art. 16 da Constituição determina que nenhuma nova lei que alterar o processo eleitoral será aplicada à eleição que ocorrem em até um ano da data de sua vigência.

Em decisão proferida em 22 de março de 2006, O plenário do STF decidiu que a verticalização vigeria para as eleições de 2006, já que a EC nº 52/2006 atentou contra a anterioridade eleitoral, ou seja, por ter sido aprovada e promulgada já em 2006, quando o prazo máximo era um ano antes da realização do pleito de outubro de 2006 .

19 Consulta n. 1.185/DF, Resolução TSE n. 22.161, rel. Min. Marco Aurélio, rel. para resolução Min. Caputo Bastos, j. 03.03.2006.

$20 \mathrm{ADI}$ n. 3.685/DF, rel. Min. Ellen Gracie, j. 22.03.2006. 
A Ação Direta de Inconstitucionalidade $n^{\circ}$. 3.685 foi julgada procedente ${ }^{21}$ por maioria de votos, sendo vencidos os Ministros Marco Aurélio e Sepúlveda Pertence.

Houve inúmeras críticas ao princípio da coerência nas coligações partidárias implantado pelo TSE por meio da Resolução n. 20.993, após decisão proferida na Consulta n. 715/DF - Resolução TSE n. 21.002, de 26 de fevereiro de 2002, relatado pelo Ministro Garcia Vieira.

Mônica Herman Salem Caggiano, por exemplo, argumenta que a verticalização força as eleições presidenciais seguirem o que ocorre no Estado de São Paulo, ou seja, uma bipolarização PT-PSDB, fato que não ocorre em parte dos estados brasileiros. Outra alegação de Caggiano recai no fato de que a aprovação da resolução emitida pelo TSE ocorreu em fevereiro de 2002, portanto, menos de um ano para as eleições gerais de seis de outubro daquele $a^{22}$. Nesse mesmo sentido, já nos manifestamos anteriormente:

\footnotetext{
21 Pode-se selecionar um trecho do voto do Ministro Carlos Brito como espécie de resumo da argumentação da maioria dos ministros que votaram a favor da vigência da "verticalização" nas coligações de 2006: "Sendo a eleição para cargos eminentemente políticos um momento do processo eleitoral que tem tudo a ver com a concreção de excelsos valores constitucionais (soberania popular, pluralismo político, elegibilidade, Justiça Eleitoral, Federação, e o princípio mesmo da separação dos poderes), envolvendo, além do mais, protagonistas públicos e privados que a própria Constituição Federal se encarregou de nominar e prestigiar de modo exponencial (eleitores, candidatos, partidos políticos, magistrados), era preciso assegurar a esses protagonistas e àqueles valores um certo período de fixidez legislativa. Um espaço de tempo imune a alterações do quadro normativo da pugna eleitoral, até porque a modificação de tais regras no próprio ano de implemento de uma eleição geral fica mais bem exposta a riscos - volta-se a dizer - de precipitação e casuísmo. Precipitação e casuísmo, no sentido que, na efervescência emocional de um ano já destinado à realização de um pleito geral, as leis já tendem a se orientar por critérios que passam ao largo de uma maturada reflexão". 22 Cf. CAGGIANO, Monica Herman Salem. "Coligações partidárias: verticalizar ou não-verticalizar?". In: Revista da Faculdade de Direito da Universidade de São Paulo, v. 100, 2005, pp. 201- 207.
} 
"Ademais, houve também o desrespeito ao princípio da anualidade eleitoral e ao princípio da segurança jurídica no advento da "verticalização", em 2002: a decisão do TSE que modificou os paradigmas das coligações partidárias veio à tona em fevereiro de 2002, portanto, após setembro de 2001, em clara ofensa à anualidade eleitoral prevista no art. 16 da Constituição. Já a segurança jurídica não foi efetiva, pois os partidos até então poderiam se coligar com quem preferissem, e pouco tempo antes da eleição, o Judiciário interveio e determinou novas regras para as $\operatorname{alianças}^{23} "$

Em 2006, como visto, com a verticalização em vigor, O STF determinou que a EC n. 52/2006 não vigeria nas eleições de outubro de 2006. A emenda, se vigesse, atingiria também a segurança jurídica. Com a decisão do STF, evitou-se mais uma vez a prevalência da pressa e dos interesses de inúmeros políticos sobre a vigência da segurança jurídica e do devido processo legal eleitoral, pois os eleitores, os candidatos e a própria Justiça seriam prejudicadas se a EC $\mathrm{n}^{\circ}$. 52/2006 vigorasse já em outubro de $2006^{24}$.

Alegou-se, contra essa crítica, que, na decisão sobre a verticalização, não se tratou de assunto que tange ao processo eleitoral, conforme preceitua o princípio constitucional da anterioridade eleitoral, mas sim um princípio que afeta tão somente os partidos políticos.

O STF arrazoou que qualquer assunto que diga respeito a mudanças na correlação de forças ou nas

\footnotetext{
23 REIS, Daniel Gustavo Falcão Pimentel dos; MACEDo, Rafael Rocha de. "Os partidos políticos e as campanhas eleitorais brasileiras: sistema normativo, propostas de reforma legislativa e as recentes decisões do Supremo Tribunal Federal". In: CAGGIANO, Monica Herman Salem (org.), Comportamento eleitoral, Barueri, Manole, 2010, p. 179.

${ }^{24}$ Cabe lembrar que a anterioridade eleitoral foi instituída justamente para que regras eleitorais não tivessem caráter casuístico e para que também não fossem aprovadas de "supetão", prejudicando os interessados (ou seja, todos os cidadãos) com regras precipitadas e aprovadas pouco tempo antes dos pleitos, com grandes chances de existirem para beneficiar certo grupo ou partido político.
} 
regras de competitividade eleitoral se refere ao processo eleitoral. Portanto, a supressão da verticalização das alianças partidárias nesse momento, conforme dispunha a EC n. 52/2006, afetaria sim o princípio da anterioridade eleitoral, por se tratar de tópico que faz parte do processo eleitoral. O argumento é, por conseguinte, cabível também contra decisão da Justiça Eleitoral.

Ademais, apontou-se que 0 Poder Judiciário, por meio do TSE e do STF, promoveu uma ingerência contra a autonomia partidária, assegurada constitucionalmente (art. 17), já que a verticalização impedia que os partidos se coligassem com quem quisessem.

Outra crítica, essa no campo político, diz respeito à artificialidade das coligações formadas nos Estados diante da definição da coligação que concorrerá à eleição presidencial.

Lembrou-se inclusive da regra vigente nas eleições de 1982, o chamado voto vinculado, que funcionava da seguinte maneira: os votos para todos os cargos disputados no pleito (governador, deputado federal, senador, deputado estadual e em algumas cidades vereador) deveriam ser para o mesmo partido, inexistindo possibilidade de voto em candidatos de outras agremiações.

Foram lançadas, por fim, críticas sobre uma possível atuação indevida do Judiciário no processo eleitoral. O Poder Judiciário estaria tomando uma postura ativista, pois é de competência do Congresso Nacional legislar sobre o sistema político-eleitoral. Esta tese dará consistência a essas críticas em específico, analisando as decisões sobre a verticalização. 
Cabe ressaltar que, no entendimento do TSE e do STF nas decisões proferidas em 2002 e 2006, o princípio da coerência nas coligações partidárias já existia no ordenamento jurídico brasileiro antes da consulta apresentada pelos deputados do PDT, assim como no caso da fidelidade partidária. O TSE, ao emitir a contestada resolução, teria proferido somente uma nova interpretação sobre a possibilidade de alianças partidárias, inclusive regulamentando o tema.

Ao instituir a verticalização, pareceu que a intenção do TSE foi a de garantir a coerência ideológica das coligações partidárias. Até 1998, realmente era muito comum que partidos rivais no âmbito nacional formassem coligações em alguns estados com o objetivo de vencer adversários comuns.

O fato, porém, é que tanto em 2002 como nas eleições de 2006 puderam-se acompanhar em muitos estados coligações falsas, onde rivais estavam "unidos" somente porque seus partidos pactuaram alianças no âmbito nacional. As alianças no âmbito estadual quase sempre seguem a lógica exclusivamente daquele estado, e não a lógica nacional.

Mesmo reconhecendo a boa intenção do TSE em garantir maior coerência ideológica nas coligações partidárias, é forçoso reconhecer que a Corte exacerbou sua função regulamentar, incidindo, conforme será defendido neste trabalho, em atividade ativista.

Após esse estudo, o passo seguinte será esgotar toda a doutrina existente sobre o tema para 
entender a reação existente no meio acadêmico (tanto no campo do Direito como também na Ciência Política) e, por fim, estudar todos os votos emitidos nas respectivas decisões, esmiuçando assim os argumentos que justificaram tal decisão.

\subsection{Contribuição original à ciência jurídica brasileira}

O tema da reforma política é bastante amplo e vem sendo debatido por juristas, cientistas políticos, jornalistas especializados na cobertura dos fatos da política brasileira e também pela sociedade desde o advento da Constituição de 1988 .

Nesse contexto, este trabalho traz estudo de fundamental importância no que toca à evolução histórica do sistema partidário-eleitoral brasileiro. Uma reconstrução desse período de debates acerca da coerência nas alianças partidárias e, especialmente, a atuação do Poder Judiciário servirá para que se possam entender os parâmetros e contextos vividos pela sociedade brasileira durante a consolidação do sistema de alianças partidárias. Esse contexto nos conduziu ao sistema partidário que temos hoje, seja ele criticado ou não.

O presente trabalho se beneficiará da limitação temporal do debate. Examinará as principais decisões exaradas pelo Tribunal Superior Eleitoral e pelo Supremo Tribunal Federal no que toca ao sistema partidárioeleitoral brasileiro, em especial no caso da verticalização das coligações partidárias, porque a compreensão da atuação do Judiciário nesse caso temporalmente balizado permite um avanço na avaliação do fenômeno do ativismo judicial na Justiça Eleitoral brasileira por meio de sua função 
normativa/regulamentar. Do mesmo modo, é forçoso reconhecer que todas as decisões exaradas pelo STF e pelo TSE sobre o tema são de suma importância para o entendimento do regime normativo que vigeu nas eleições de 2002 e 2006.

Essas decisões foram notoriamente significativas para o contexto político brasileiro, passado e atual. Qualquer pesquisa acadêmica que tivesse como escopo uma análise de maior profundidade dos argumentos presentes em todos os votos exarados, acompanhada de extenso estudo sobre a conjuntura histórica e política e com destaque às repercussões doutrinárias já seria de grande valor para a ciência jurídica brasileira.

Este trabalho, porém, pretende dar mais um passo. As decisões do TSE e do STF que trataram da verticalização das coligações partidárias também serão objeto de um estudo mais detalhado sobre uma possível ingerência do Poder Judiciário em matéria de competência do Poder Legislativo.

O fenômeno conhecido como "judicialização da política" vem sido debatido nos meios acadêmicos e também entre os próprios atores envolvidos (membros do Poder Judiciário, do Poder Legislativo e até do Poder Executivo) .

Esse fenômeno pode ser acompanhado nos mais diversos ramos da ciência jurídica, como, por exemplo, na "judicialização" das políticas públicas de saúde. Atualmente, diversos cidadãos, alegando em sua defesa dispositivos constitucionais, vão ao Poder Judiciário para que ele garanta medicamentos ou tratamentos de saúde que o Estado brasileiro se nega a fazer. No campo político não é 
diferente. Nos últimos anos, pôde-se acompanhar um crescimento do papel do Poder Judiciário (principalmente do TSE e do STF) em decisões que envolvem questões partidárias, eleitorais e congressuais.

Os estudos sobre as causas da judicialização não são consensuais ${ }^{25}$. São consideradas causas a própria estrutura institucional brasileira pós1988, mais especificamente a redemocratização, a constitucionalização abrangente e o controle de constitucionalidade. A causa mais patente, contudo, da judicialização (e possível ativismo) no campo dos processos eleitorais seriam os problemas que afligem o Poder Legislativo.

Enfraquecido pela grande força do Executivo e acusado de inoperância (além do envolvimento em denúncias de corrupção dos mais diversos tipos), o Congresso Nacional padece de dois graves problemas: (i) seus conflitos internos acabam chegando ao Judiciário, visto sua notória incapacidade de resolver suas questões internas; (ii) sua função primordial, que é a de legislar em prol da sociedade brasileira, se vê ameaçado pelo chamado "poder de agenda" do Executivo: praticamente somente os projetos de interesse do Presidente da República são debatidos e levados ao Plenário.

Nesse grave contexto, a reforma política é sempre lembrada por políticos e pelos estudiosos da política nos seus mais diversos campos como uma das prioridades, como um dos temas mais importantes a ser debatido e votado. No entanto, o que se vê são apenas

${ }^{25}$ Vide item 2.2 infra. 
mudanças pontuais na legislação eleitoral-partidária brasileira ${ }^{26}$.

Como consequência dessa lentidão proposital ou não em se tratando de reforma política - foi observada a assunção do tema pelo Poder Judiciário, que, quando provocado, não se ausentou e decidiu questões importantíssimas do cenário político brasileiro, dentre elas a questão da fidelidade partidária e o objeto desta tese, a verticalização das coligações partidárias ${ }^{27}$.

$\mathrm{Na}$ emblemática decisão sobre o instituto da fidelidade partidária, o Judiciário não só decidiu a questão, mas também regulamentou o devido processo legal para a análise de eventual ação para cassação de mandato de trânsfuga. Além disso, foi também o Judiciário quem decidiu quais são as hipóteses legais para que um político saia de seu partido e vá para outro sem perder o mandato ${ }^{28}$.

Quanto à verticalização, percebeu-se que o TSE mudou radicalmente sua interpretação quanto ao regime

\footnotetext{
26 Luís Roberto Barroso declara que uma das falhas institucionais do país, que repercute "sobre todo o sistema" por se tratar do "ponto baixo do modelo constitucional brasileiro (...) foi a falta de disposição ou de capacidade para reformular o sistema político". "Vinte anos da Constituição de 1988: a reconstrução democrática do Brasil". In: Revista de Informação Legislativa, ano 45, n. 179, jul./set. 2008, p. 35 .

27 Barroso também destacou o fenômeno do ativismo judicial como um dos fatores que deram ao Judiciário pós-1988 "um momento de expressiva ascensão política e institucional", pois "nesse cenário, ocorreu entre nós uma expressiva judicialização das relações sociais e de questões políticas. O Supremo Tribunal Federal (STF) ou outros órgãos judiciais têm dado a última palavra em temas envolvendo separação de Poderes, direitos fundamentais, políticas públicas, regimes jurídicos de servidores, sistema político e inúmeras outras questões, algumas envolvendo o dia-a-dia das pessoas como mensalidades de planos de saúde ou tarifa de serviço públicos. Essa expansão do papel do Judiciário, notadamente do STF, fez deflagrar um importante debate na teoria constitucional acerca da legitimidade democrática dessa atuação". "Vinte anos da Constituição de 1988: a reconstrução democrática do Brasil". In: Revista de Informação Legislativa, ano 45, n. 179, jul./set. 2008, p. 34-35 (grifos nossos).

28 Resolução TSE n. 22.610/2007.
} 
de coligações partidárias, conforme previsto no art. $6^{\circ}$ da Lei das Eleições.

Em 1998, por exemplo, a Lei n. 9.504/97 já estava em vigor, e mesmo com uma decisão em sede de consulta que questionava o regime de coligações nas eleições gerais daquele ano, não houve qualquer menção sobre a necessidade de haver coerência entre as coligações na eleição nacional (Presidência da República) e nas eleições estaduais (Governadores de Estado, Senado, Câmara dos Deputados e Assembleias Legislativas).

Nas eleições gerais seguintes (2002), porém, após nova provocação realizada por deputados federais do PDT, o quadro mudou radicalmente, a menos de nove meses das eleições gerais. Somente após a promulgação de uma emenda constitucional, em clara reação do Legislativo, o quadro normativo das coligações partidárias nas eleições gerais retornou ao status quo da Lei das Eleições e do pleito de 1998, sendo que graças à decisão do STF, a referida Emenda foi aplicada somente a partir das eleições de 2010.

Assim sendo, além da análise da doutrina, dos votos exarados pelos Ministros do TSE e do STF no caso escolhido e do contexto histórico e político, este trabalho pretende debruçar-se sobre o fenômeno do ativismo judicial na Justiça Eleitoral, fato este razoavelmente recente e pouquíssimo estudado, apesar de sua imensa importância para a ciência jurídica brasileira. 


\subsection{Método de estudo e de análise de decisões}

O estudo a ser desenvolvido tratará de um estudo de caso decidido pela Justiça Eleitoral sob a ótica do ativismo judicial. Nossa intenção é demonstrar que a verticalização tratou-se de uma decisão classificável como ativista, pois o TSE exacerbou de sua competência normativa/regulamentar e legislou sobre as possibilidades de coligações partidárias.

A análise da legislação brasileira atual será fundamental para compreender as razões do modo de funcionamento do regime partidário brasileiro, com especial ênfase nas disposições que tratam das coligações partidárias.

Não obstante, há uma dimensão empírica, já que decisões judiciais eleitorais serão analisadas com o intuito de verificar como a Justiça Eleitoral tratou o tema do trabalho. Ao mesmo tempo, serão campo de estudo também as decisões proferidas pelo supremo Tribunal Federal chancelando as decisões do Tribunal Superior Eleitoral que trataram da verticalização das coligações partidárias.

Será pesquisado e analisado com atenção também o histórico da peculiaridade constitucional brasileira: a competência do Poder Judiciário em administrar e regulamentar as normas eleitorais brasileiras.

O art. 23, IX, do Código Eleitoral, dispositivo normativo que prevê a competência normativa/regulamentar da Justiça Eleitoral, seria o 
principal responsável por uma possível exacerbação da Justiça Eleitoral frente ao Poder Legislativo?

Na época em que o julgamento da Consulta n. 715/DF foi realizado pelo TSE, julgamento este que mudou seu entendimento sobre as coligações partidárias nas eleições gerais brasileiras, criando-se a verticalização, o então presidente da República, Fernando Henrique Cardoso, declarou que houve com aquela decisão o início da reforma política no Brasil.

Essa decisão foi o verdadeiro leading case da força do Judiciário nas questões eleitorais. Após, diversas decisões do TSE e do STF mudaram substancialmente diversas questões do sistema político-eleitoral brasileiro. O Legislativo, ao se esquivar de fazer a tão propalada reforma política, teve que se contentar com o papel de coadjuvante na verdadeira revolução feita pelo Judiciário no tema.

Destaca-se que somente em poucas ocasiões houve uma espécie de reação do Congresso Nacional para reverter essas impactantes decisões judiciais que tanto mudaram o sistema político-eleitoral brasileiro. Um dos casos foi o da verticalização e, por isso, esse caso concreto foi o escolhido para uma análise mais profunda.

Assim, esse trabalho trará a análise de todos os votos proferidos em todas as decisões que trataram da verticalização das coligações partidárias no TSE e no STF ocorridos entre a primeira decisão que marcou a nova interpretação das coligações partidárias brasileiras, no início de 2002, e o fim da verticalização, com a promulgação da Emenda Constitucional n. 52/2006. 


\section{O Fenômeno do Ativismo Judicial no Brasil}

\subsection{Introdução}

Neste capítulo, será estudado o fenômeno do ativismo judicial no Brasil. O objetivo desta análise não é fazer um exame pormenorizado do tema, tópico suficiente para uma tese em separado. Nesta oportunidade, o foco será contextualizar o fenômeno no panorama constitucional brasileiro e situar metodologicamente este trabalho em meio às diversas abordagens a respeito do ativismo.

Primeiramente, para atingirmos o objetivo, será necessário um estudo da evolução histórica do fenômeno do ativismo judicial. As origens desse fenômeno podem ser traçadas até o início do século XIX com a decisão proferida pela suprema Corte dos Estados Unidos que criou a jurisdição constitucional (Marbury v. Madison, 1803) 29, trata-se de fato bastante controvertido até os dias atuais no entre os juristas estadunidenses.

Após entender o fenômeno sob a perspectiva histórica, buscaremos apresentar o conceito que será aplicado para a avaliação das decisões sobre a verticalização. Para tanto, relembraremos as diferenças do sistema da common law estadunidense e do sistema jurídico brasileiro, de base romano-germânica. A conceituação do fenômeno, sob a ótica brasileira, calcada na análise da

29 Cf. GREEN, Craig. "An intellectual history of judicial activism". In: Emory Law Journal, n. 01, v. 58, 2009, p. 1196-1263. Dentre os estudiosos do ativismo, nem mesmo sobre a origem do fenômeno há consenso. Outros autores consideram o caso Lochner como a primeira ocorrência do fenômeno. KMIEC, Keenan D. "The origin and current meaning of 'judicial activism"..In: California Law Review, v. 92, 2004. A história do termo - diferente da história do fenômeno - é mais clara, como se verá adiante. Vide item 2.2 infra. 
produção doutrinária nacional e que considerou, obviamente, as características dos sistemas político e jurisdicional pátrios, será de enorme importância para o seguimento deste trabalho, principalmente quando analisarmos os papéis constitucionais e legais da Justiça Eleitoral no Brasil, com destaque ao exercício das suas funções regulamentar e consultiva ${ }^{30}$.

Este aprofundamento teórico e conceitual é necessário para atingir o objetivo da tese. Questiona-se: afinal, ao tratar da verticalização, O TSE e o STF agiram de acordo com suas competências constitucionais ou as ultrapassaram? A fixação de um conceito de ativismo judicial, levando-se em conta as peculiaridades brasileiras, é essencial para a compreensão da formulação e da resposta a essa questão.

A terceira parte deste capítulo consistirá num estudo sobre as causas do aparecimento deste fenômeno no Brasil. O fenômeno do ativismo judicial será, então, relacionado à judicialização da política, própria da estrutura institucional criada a partir do advento da Constituição de 1988 .

Por fim, identificado o fenômeno pela perspectiva histórica, apresentada sua conceituação e situado nos contextos jurídico e político brasileiros, traremos à baila o exame de decisões do Supremo Tribunal Federal que demonstram a vivacidade do fenômeno do ativismo judicial em questões político-eleitorais do País.

30 Vide Capítulo 3 infra. Como já destacado no capítulo anterior, as decisões proferidas pelo Tribunal superior Eleitoral e pelo supremo Tribunal Federal no que tange à verticalização das coligações partidárias ganharão um capítulo à parte (capítulo 4). 


\subsection{Histórico do fenômeno. Conceituação de ativismo judicial}

O termo "ativismo judicial" surgiu nos Estados Unidos e relacionava-se à atuação da Suprema Corte. Quando foi usado pela primeira vez, não foi acompanhado de uma definição precisa. O professor de Harvard, Arthur Schlesinger, inaugurou o uso acadêmico do termo. Em artigo que avaliava a suprema Corte após dez anos do final da chamada era Lochner, e sem grande rigor metodológico, Schlesinger, historiador de renome, dividiu os ministros da Suprema Corte em "ativistas" e "campeões da autocontenção". Os primeiros teriam uma postura mais inovadora, enquanto os outros decidiam de modo mais comedido. Não havia grandes bases empíricas para essa classificação, mas o termo "ativista" foi bem recebido ${ }^{31}$.

Há uma noção de interferência na ideia de ativismo de Schlesinger, apesar da simplicidade metodológica do artigo. Craig Green afirma que, para ser relevante a distinção feita por Schlesinger, o fenômeno não podia ser algo desconhecido da justiça estadunidense.

Essa noção dá base para estudos de uma "pré-história" do ativismo judicial. Seria possível encontrar momentos de ativismo sempre que houvesse críticas contra decisões judiciais que ora aumentavam o poder do judiciário ora diminuíam o poder do governo. Já havia ataques nesse sentido contra as decisões da corte de Marshall e da Era Lochner.

31 Cf. GREEN, Craig. "An intellectual history of judicial activism". In: Emory Law Journal. N. 1. Vol. 58. p. 1196-1263. 2009. p. 1201. Ver também: KMIEC, Keenan D. "The origin and current meaning of judicial activism". In: California Law Review, v. 92, 2004; BICCA, Carolina Scherer. "Desmistificando o ativismo judicial". In: Direito Público (DPU), n. 46, jul./ago. 2012, p. 213-226. 
Desde então haveria reações por parte dos candidatos à Casa Branca. Desde Lincoln, rejeitavam-se decisões do Judiciário consideradas invasoras de tópicos políticos. No século Xx, Nixon e Reagan também prometeram, em suas campanhas, não indicar juízes ativistas. Contudo, as cortes desse período (Warren, Burger, Rehnquist) tiveram episódios de ativismo ${ }^{32}$.

A partir do artigo de Schlesinger, o ativismo foi sendo aplicado para avaliar a atuação da Suprema Corte dos Estados Unidos. Em um primeiro momento, o termo teve conotação positiva, com a defesa dos civil rights, mudanças progressistas e prevenção contra medidas regressivas dos outros poderes. O caso de ativismo judicial mais elogiado é o conhecido Brown vs. Board of Education, que proibiu a segregação racial nas escolas.

A aplicação negativa do termo faz referência ao fato de o poder judiciário ultrapassar sua competência legalmente prevista. Nos Estados Unidos, essa última tem preponderado. Ainda que estudos mais cuidadosos tentem demonstrar que há situações de ativismo - no sentido de ultrapassagem de limites da função jurisdicional - tanto benéficas como maléficas; progressistas e conservadoras, a tendência é usar o termo "ativismo judicial" como base para críticas às decisões judiciais mais polêmicas ${ }^{33}$.

Ao traçar o panorama histórico do tema, fica clara a necessidade de uma ressalva. Para entendermos a evolução da análise do fenômeno, visando a sua

\footnotetext{
32 Cf. BICCA, Carolina Scherer. "Desmistificando o ativismo judicial". In: Direito Público (DPU), n. 46, jul./ago. 2012, p. 213-226.

33 Cf. GREEN, Craig. "An intellectual history of judicial activism". In: Emory Law Journal. s. I. Vol. 58. p. 1196-1263. 2009; CROSS, Frank B.; LINDQUIST, Stefanie A. "Scientific study of judicial activism". In: The Minnesota Law Review, v. 91, 2006, p. 1752.
} 
conceituação, é necessário relembrar que as diferenças entre os sistemas jurídicos adotados por Estados Unidos, onde o termo "ativismo judicial" foi inicialmente invocado, e pelo Brasil, nosso campo de estudo, pode induzir a premissas equivocadas.

No sistema da common law, de origem anglo-saxã, os tribunais são produtores de normas abstratas - os chamados precedentes - e, por isso, o fenômeno se expande e se confunde com a própria adaptação do direito às rápidas mudanças na sociedade contemporânea. Na civil law, de inspiração romano-germânica, o ativismo judicial restringe-se à violação da separação de poderes, invadindo a competência, na maior parte das vezes, do Poder Legislativo ${ }^{34}$.

Entendida a evolução histórica do ativismo judicial, passamos agora à busca de um conceito. A conceituação de ativismo judicial, como se pode depreender do histórico, é um trabalho bastante difícil. Atualmente, mesmo nos Estados Unidos, ainda há discussões a respeito de como fixar um conceito de "ativismo judicial". A escolha dos critérios para classificar decisões como ativistas ou não é objeto de intenso debate nos meios jurídicos estadunidenses. No Brasil, a situação não é diferente ${ }^{35}$.

\footnotetext{
34 Cf. RAMOS, Elival da Silva. Ativismo judicial: parâmetros dogmáticos. São Paulo: Saraiva, 2010, p. 129.

35 Nesse sentido, Marcelo Casseb Continentino, ao estudar o tema do ativismo, ressalta a dificuldade em se trabalhar o tema. Afirma que "é grande a dificuldade na utilização do conceito e ativismo judicial no Brasil. (...) há múltiplos sentidos e significados que se pretendem discutir ou constituir, mediante o conceito que não necessariamente corresponde à realidade.". CONTINENTINo, Marcelo Casseb. "Ativismo judicial: considerações críticas em torno do conceito no contexto brasileiro". In: Interesse público, v. 14, n. 72, mar./abr. 2012, p. $123-55$.
} 
Bradley C. Canon demonstrou com vigor esta dificuldade no âmbito dos Estados Unidos. Para Canon, ao seguir-se a evolução histórica da Suprema Corte dos EUA, nota-se nitidamente o desenvolvimento da análise de suas decisões sob o signo do ativismo judicial. Separa-se, por exemplo, a época do New Deal, a chamada Era Lochner. Neste momento político e econômico dos EUA, a discussão se enviesava pela questão da usurpação de competências dos órgãos eletivos (Legislativo e Executivo). Já num momento posterior (década de 1960), quando a Suprema Corte dos EUA esteve sob os auspícios da chamada "Corte de Warren", o fenômeno do ativismo judicial foi analisado sob a perspectiva da descontinuidade de precedentes ${ }^{36}$.

No intuito de definir limites teóricos na análise do fenômeno, Canon trouxe à baila seis dimensões da atividade jurisdicional necessárias para a identificação do ativismo judicial na análise de uma decisão judicial.

- primeiro deles é o majoritarismo (majoritarianism). Nessa dimensão, o ativismo é medido conforme o grau que políticas públicas (policies) adotadas por meio de processos democráticos são negadas pelo Judiciário. A segunda dimensão é a estabilidade interpretativa. Nela, o ativismo pode ser encontrado no grau em que a corte altera decisões e doutrinas pretéritas. Essa alteração (overrulling) pode ser tanto explícita quanto implícita. Nela, pode-se encontrar também uma espécie de 'interpretação contínua' (ongoing interpretation) da constituição.

36 Cf. CANON, Bradley C. "Defining dimensions of judicial activism". In: Judicature, v. 66, n. 6, dec./jan. 1983, p. 236-247. 
A terceira dimensão é a fidelidade interpretativa. Nela, deve ser medido o grau em que a interpretação do texto constitucional é contrária a claras intenções de seus elaboradores ou é contrária ao sentido claro da linguagem aplicada. Aqui podem ser mensuradas as construções efetivas e derivadas de normas constitucionais feitas pelos tribunais: insere-se, portanto, o debate sobre a interpretação da Constituição e os limites da discricionariedade dos juízes.

A quarta dimensão consiste na distinção entre processo substantivo/material e processo democrático. Aqui se verifica o grau em que decisões judiciais criam políticas públicas substantivas ao invés de garantir o processo democrático. Para Canon, levando-se em conta essa dimensão, há duas áreas em que seria aceitável a criação de políticas públicas pelas cortes, quais sejam: (i) julgamento de legislação que restringe processos legislativos que produzem normas indesejáveis; e (ii) julgamento de legislação com sérias tendências a diminuir a "operatividade" dos processos políticos dos quais se espera proteção para minorias.

Seguindo essa distinção, Canon aponta que a maior parte da doutrina estadunidense entende que decisões que tratam de processo político (liberdade de expressão, condução de eleições, natureza da representação) não devem ser consideradas ativistas. Estes tópicos não afetam diretamente as políticas materiais. Ativistas, nessa visão, seriam apenas as decisões que fazem política pública de cunho econômico e social e que, consequentemente, afetam diretamente a vida privada do indivíduo. 
A quinta dimensão trata da especificidade da política pública. Nela mede-se o grau pelo qual o tribunal estabelece uma política pública, não deixando o Judiciário à discricionariedade de outros agentes políticos. Canon cita como exemplo dessa dimensão o notório caso Roe $v$. Wade. Ao delimitar as leis sobre a possibilidade de aborto nos Estados, a Corte atuou como criador de política pública.

Finalmente, a sexta dimensão é a existência de formuladores alternativos de política pública. Nela, mensura-se o grau em que os tribunais desprezam considerações de outros agentes governamentais sobre o mesmo problema. Há aqui discussão de aspectos políticos, mas também problemas de expertise técnica. Para Canon, o ativismo ocorre quando há boa probabilidade de que outro formulador de política pública tenha tomado a mesma decisão em um futuro próximo ou esteja mais bem informado para decidir ${ }^{37}$.

Os critérios utilizados nos EUA são importantes para que conheçamos com mais detalhes as vertentes existentes neste fenômeno. Todavia, diante das diferenças entre o sistema jurídico estadunidense e o brasileiro, conforme já tratado aqui, tentaremos conceituar ativismo judicial levando em conta as peculiaridades do nosso País.

Essa distinção é necessária porque no sistema da common law, o direito legislativo é quase considerado uma fonte excepcional do direito. Nos EUA, por exemplo, é bastante mais complicado caracterizar o que

\footnotetext{
${ }^{37}$ Cf. CANON, Bradley C. "Defining dimensions of judicial activism". In: Judicature, v. 66, n. 6, dec./jan. 1983, p. 236-247.
} 
seria uma decisão judicial que tenha uma espécie de disfunção, de exacerbação no exercício da função jurisdicional ${ }^{38}$. Além disso, é forçoso reconhecer que o maior poder do Judiciário é fato resultante de uma evolução histórica iniciada há mais de duzentos anos.

No contexto brasileiro, qual seja, a vigência do sistema da civil law, no qual a interpretação do direito positivo prepondera, o ativismo judicial deve ser estudado como uma espécie de disfunção do exercício da função jurisdicional. Nesse ponto, a separação de Poderes é - princípio constitucional que mais corre risco de ser desrespeitado.

Não se trata aqui de pensar que defendemos a atuação da magistratura no modo mecânico, como se defendeu no passado. Reconhecemos o novo papel fundamental do Judiciário na garantia dos direitos fundamentais e como casa de resolução de conflitos existentes na sociedade. A interpretação da norma jurídica é função do magistrado. Essa função, porém, não é mais importante, tampouco superior à função legislativa ${ }^{39}$.

38 Nesse sentido, Elival da Silva Ramos atesta que "Se o ativismo judicial, em uma noção preliminar, reporta-se a uma disfunção no exercício da função jurisdicional, em detrimento, notadamente, da função legislativa, a mencionada diferença de grau permite compreender porque nos ordenamentos filiados ao common law é muito mais difícil do que nos sistemas de família romano-germânica a caracterização do que seria uma atuação ativista da magistratura, a ser repelida em termos dogmáticos, em contraposição a uma atuação mais ousada, porém ainda dentro dos limites do juridicamente permitido". (In: Ativismo judicial: parâmetros dogmáticos. São Paulo: Saraiva, 2010, p. 107).

39 No mesmo sentido, assinala Elival da Silva Ramos: "As decisões judiciais, portanto, são, como já foi visto, necessariamente criativas e inovadoras, não apenas porque geram a denominada norma de decisão (ponto culminante do processo de concretização normativa), mas, principalmente, porque esta não se limita a reproduzir o que está nos textos paramétricos, os quais são desdobrados, adaptados e, porque não dizer, enriquecidos para poderem disciplinar adequadamente a situação fática que provocou a atuação da jurisdição. Entretanto, não se pode negar que a liberdade de criação deferida pelo sistema jurídico aos aplicadores oficiais do direito é significantemente menor do que aquela reservada ao Poder Legislativo ou ao órgão que com ele 
Nossa preocupação dirige-se ao fato de quando imbuído de bons motivos e valores, o Judiciário, cotidianamente, ultrapassa a linha de competência delineada pela Constituição. Trata-se de uma situação paradoxal. o art. 102, caput, da CRFB/1988 determina que o papel precípuo do STF é a guarda da Constituição. Por vezes, o STF e outros órgãos do Judiciário, em muitas oportunidades no afã de fazer justiça, ultrapassam os limites constitucionais. Ou seja, o controlador infringe a norma fundamental em que se baseia o controle que ele exerce sobre os outros Poderes. Elival da Silva Ramos deixa essa noção nítida ao afirmar que

"A observância da separação dos Poderes importa, dentre diversos outros consectários, na manutenção dos órgãos do Judiciário nos limites da função jurisdicional que lhes é confiada e para cujo exercício foram estruturados ${ }^{40,}$.

Assim sendo, podemos considerar que a exacerbação dos limites existentes no que tange à criatividade da jurisprudência decorre em consequências maléficas às demais funções do Estado, principalmente a legislativa ${ }^{41}$. Essa exacerbação, indubitavelmente, acarreta no desrespeito ao princípio constitucional da separação dos

compartilhe a função legislativa". (In: Ativismo judicial: parâmetros dogmáticos. São Paulo: Saraiva, 2010, p. 119).

40 RAMOS, Elival da Silva. Ativismo judicial: parâmetros dogmáticos. São Paulo: Saraiva, 2010, p. 117.

41 Elival da Silva Ramos relembra com maestria os limites da função legislativa, conforme se depreende do trecho a seguir explicitado: "Com efeito, na tarefa de compor o nível primário do ordenamento jurídico, o legislador está limitado apenas às normas constitucionais, não se podendo olvidar que as constituições se circunscrevem à normatização dos aspectos fundamentais da organização estatal e de sua interface com a sociedade civil (direitos fundamentais e princípios da ordem econômica e social), fazendo-o de modo textualmente aberto (normas-princípio, conceitos indeterminados etc.), o que amplia ainda mais a liberdade de conformação legislativa" (In: Ativismo judicial: parâmetros dogmáticos. São Paulo: Saraiva, 2010, p. 124). 
Poderes, previsto explicitamente na Constituição brasileira no $\operatorname{art} .2^{\circ}$.

Diante do todo explanado, servimo-nos das lições de Elival da Silva Ramos para conceituar o fenômeno do ativismo judicial. Esse conceito, relembramos, será fundamental para entendermos a aplicação do fenômeno na Justiça Eleitoral (capítulo 3), com maior especificidade na análise de todas as decisões exaradas pelo TSE e pelo STF no tema da verticalização das coligações partidárias:

"por ativismo judicial deve-se entender o exercício da função jurisdicional para além dos limites impostos pelo próprio ordenamento que incumbe, institucionalmente, ao Poder Judiciário fazer atuar, resolvendo litígios de feições subjetivas (conflitos de interesse) e controvérsias jurídicas de natureza objetiva (conflitos normativos). Há, como visto, uma sinalização claramente negativa no tocante às práticas ativistas, por importarem na desnaturação da atividade típica do Poder Judiciário em detrimento dos demais Poderes ${ }^{42,}$.

\section{3: Ativismo judicial e Judicialização da Política.}

O ativismo judicial está ligado à
judicialização das relações políticas, mas não são
sinônimos. Luís Roberto Barroso esclarece que, enquanto a
judicialização é fruto da vontade do constituinte, que
promulgou carta abrangente, aumentando o escopo das funções
judiciais, o ativismo decorre de uma postura do juiz que
expande, sobretudo no âmbito constitucional, as
possibilidades de aplicação do texto normativo por meio da
interpretação ${ }^{33}$.

RAMOS, Elival da Silva. Ativismo judicial: parâmetros dogmáticos. São Paulo: Saraiva, 2010, p. 129.

43 Cf. BARROSO, Luís Roberto. "Judicialização, ativismo judicial e legitimidade democrática". In: Cadernos [SYN] THESIS, v. 5, n. 1, 2012 , p. 23-32. 
Neste tópico explicaremos a evolução da Judicialização da Política para, em seguida, relacioná-lo com as causas da propagação do ativismo judicial no Brasil.

A doutrina da separação dos Poderes clássica definia com rigidez as funções dos poderes Executivo, Legislativo e Judiciário. A função jurisdicional tinha como objetivo primordial trazer a vontade da lei para - caso concreto. Sendo a lei clara, não haveria espaço para a interpretação do juiz. O trabalho deste era desdobrar, de maneira quase mecânica, a vontade da lei ${ }^{44}$.

Essa doutrina sofreu seu primeiro temperamento com o advento da jurisdição constitucional. Após a decisão da Suprema Corte dos Estados Unidos no caso Marbury v. Madison, em 1803, criou-se a noção de que a atividade legislativa tinha um limite, qual seja: o texto constitucional.

A criação da jurisdição constitucional revolucionou o direito e a noção de limitação de poderes. Esta decisão iniciou um processo que está em evolução hodiernamente. A função clássica do Poder Judiciário, qual seja, a jurisdicional, ganhou um fundamental acréscimo: cabia à Suprema Corte a palavra final sobre a interpretação do texto constitucional. Qualquer órgão do Judiciário

\footnotetext{
44 Celso Fernandes Campilongo destaca que a função jurisdicional tinha outra conotação nos países que adotaram a common law, in verbis: "Durante muito tempo a doutrina foi reticente em admitir a atividade 'criadora do direito' do magistrado. Exceção feita à tradição da 'common law' nos países de tradição positivista a atividade do juiz sempre foi descrita como um desdobramento quase mecânico da 'vontade da lei'. Diante da clareza da lei, cessa o espaço para a interpretação. Isso pressupõe que os problemas jurídicos possam ser resolvidos mediante uma única resposta legítima". (CAMPILONGo, Celso Fernandes. Política, sistema jurídico e decisão judicial. São Paulo: Max Limonad, 2002, p. 47).
} 
poderia tratar da constitucionalidade das normas. A palavra final, porém, era do órgão de cúpula.

Na Europa, este fenômeno repercutiu de forma originalmente diferente. No Velho Continente, sob inspiração das ideias do austríaco Hans Kelsen, foram criados Tribunais Constitucionais com 0 intuito de eles procederem com exclusividade à jurisdição constitucional. Para Roger Leal, por exemplo, a corte que tem como incumbência a jurisdição constitucional transforma-se em verdadeiro árbitro dos conflitos entre os Poderes do Estado, papel, portanto, de extrema relevância no panorama político de um Estado Democrático de Direito ${ }^{45}$.

O Brasil, que desde o advento da Constituição de 1891 havia optado por seguir o modelo estadunidense, começou a desenhar, em 1965, um modelo institucional híbrido. Esse sistema misto foi coroado com a Constituição de 1988. Além do sistema de controle de constitucionalidade difuso, a competência do STF para o exercício do controle de constitucionalidade concentrado cresceu de forma decisiva. Ademais da previsão constitucional de novos entes com legitimidade ativa para ajuizar ações diretas de inconstitucionalidade (em comparação à Carta de 1967, que só conferia legitimidade ao Procurador-Geral da República), houve também a criação de novos mecanismos jurídicos, como a ação declaratória de

\footnotetext{
45 Cf. Roger stiefelmann Leal, que sentencia, in verbis: "É correto afirmar, nesse sentido, que as divergências surgidas entre os órgãos político-constitucionais ou a respeito de suas condutas ficam submetidas, em última instância, ao juízo daqueles incumbidos da prática da jurisdição constitucional. Os órgãos de jurisdição constitucional exercem, desse modo, uma função de juiz dos demais órgãos estatais, de árbitro supremo dos conflitos entre os poderes". (O efeito vinculante na jurisdição constitucional. São Paulo: Saraiva, $2006, p .37$ ).
} 
constitucionalidade e a arguição de descumprimento de preceito fundamental ${ }^{46}$.

A jurisdição constitucional deu ao Judiciário um novo protagonismo no Estado Democrático de Direito moderno. A expansão do modelo estadunidense de primazia da constituição levou à implementação dessa estrutura institucional como inerente ao Estado Democrático de Direito. Inclui-se nessa onda de democratização e redemocratização o Brasil pós-1988. Tamanho é o protagonismo do judiciário nesse modelo que fala-se, hoje, em "juristocracia" 47. Na doutrina nacional, Roger Leal compara o papel da corte detentora da competência jurisdicional constitucional com o exercício do Poder Moderador previsto na Constituição do Império de 1824, conforme trecho a seguir:

"Trata-se de uma jurisdição que se sobrepõe aos demais poderes estatais, com o propósito de defender os objetivos permanentes do Estado - hoje, consagrados no texto constitucional - e resolver os conflitos entre os poderes, bem como controlar a licitude e a moralidade dos órgãos políticos e da administração. $\mathrm{Na}$ atualidade, tais tarefas encontram-se, em grande parte, absorvidas pela jurisdição constitucional, última instância de resolução de conflitos entre órgãos e grupos políticos e guarda supremo dos valores e objetivos permanentes do Estado consagrados, ainda que implicitamente, na Constituição ${ }^{48, "}$

\footnotetext{
46 No mesmo sentido, Oscar Vilhena Vieira assevera que: "O hibridismo de nossa jurisdição constitucional lhe dá um alto grau de complexidade, sofisticação e originalidade, na medida em que autoriza a todo e qualquer magistrado exercer, num caso concreto, o juízo de censura àqueles que violarem a Constituição, ao mesmo tempo em que permite a um largo leque de autoridades, partidos políticos e entidades da sociedade civil buscar, junto a um órgão especial, o controle abstrato da constitucionalidade das leis". (Supremo Tribunal Federal: jurisprudência política. São Paulo: Malheiros, $2^{a}$ ed., 2002, p. 218 ).

47 Cf. Hirschl, Ran. Towards juristocracy: the origins and consequences of the new constitutionalism. Cambridge, EUA: Harvard University Press. 2004 .

48 LEAL, Roger Stiefelmann. O efeito vinculante na jurisdição constitucional. São Paulo: Saraiva, 2006, p. 38-39. Oscar Vilhena Vieira faz a mesma comparação, ao mencionar que o STF, nos dias de hoje, tem papel assemelhado com o Poder Moderador previsto na Constituição do Império (Cf. VIEIRA, Oscar Vilhena. Supremo Tribunal
} 
O novo protagonismo do Judiciário também é destacado por Celso Campilongo. Para o autor, o alargamento das funções do Estado redundou no crescimento das instituições de controle de Poder. Sendo o Judiciário o guardião do texto constitucional, passa a ser o órgão de cúpula uma "importante arena de exposição, afirmação e condensação dos conflitos através de operações estratégicas49".

Essa proeminência do controle exercido pelo poder Judiciário é identificada como "judicialização da política". A judicialização não é um fenômeno que encontre definição clara entre os teóricos. Considera-se judicialização, em geral, (i) o controle pelo poder judiciário da vontade do soberano ou (ii) "o fato de questões de larga repercussão política ou social serem decididas por órgãos judiciários" 50 . Qualquer que seja a definição, o sentido geral é semelhante: há uma ampliação da atuação do poder judiciário no controle dos demais poderes.

O papel do juiz ganha corpo, mas esse protagonismo também resulta em maiores possibilidades de conflito com os outros poderes. O juiz tem a obrigação de decidir e fundamentar sua decisão com base no direito. Deve, porém, da mesma forma, "interpretar, construir,

Federal: jurisprudência política. São Paulo: Malheiros, 2a ed., 2002, P. 233).

49 CAMPILONGo, Celso Fernandes. Política, sistema jurídico e decisão judicial. São Paulo: Max Limonad, 2002, p. 62. No mesmo sentido, Rogério Arantes destaca que a "força política do Judiciário nas sociedades contemporâneas decorre da capacidade que lhe é delegada de preservar a Constituição frente aos atos dos Poderes Legislativo e Executivo". (In: ARANTES, Rogério Bastos. Judiciário \& política no Brasil. São Paulo: Idesp: Editora Sumaré, 1997, p. 201).

50 BARROSO, Luís Roberto. "Judicialização, ativismo judicial e legitimidade democrática". In: [Syn]Thesis, v. 5, n. 1, p. 23-32, 2012 . 
formular novas regras, acomodar a legislação em face das influências do sistema político". Assim, o tangenciamento entre política e magistratura torna-se inevitável ${ }^{51}$.

$$
\text { O novo papel do STF pós-1988 foi }
$$

destacado com primazia pelo Ministro Celso de Mello em artigo de sua autoria. Nele, Mello ressalta que a Constituição de 1988 ampliou as funções institucionais do Judiciário e, por isso, ganhou esse poder da República o propalado novo protagonismo, conforme se depreende do trecho exposto a seguir:

"A crescente judicialização das relações políticas em nosso País resulta de expressiva ampliação das funções institucionais conferidas ao Judiciário pela vigente Constituição, que converteu os juízes e os Tribunais em árbitros dos conflitos que se registram na arena política, conferindo, à instituição judiciária, um protagonismo que deriva naturalmente do papel que se lhe cometeu em matéria de jurisdição constitucional ${ }^{52,}$.

Diante da visão tradicional da doutrina da separação dos Poderes, o ativismo judicial tem sido foco de debates nos campos jurídico e político. Rubens Beçak, por exemplo, reforça esta preocupação ao salientar que o entrecruzamento de funções dos três Poderes, a origem da judicialização da política, pode levar à hipertrofia do Judiciário. A evolução da doutrina, segundo Beçak, leva à acomodação do Legislativo. Tanto a garantia constitucional de amplos poderes legislativos ao Executivo como a evolução histórica que acentuou o papel de legislador negativo do Judiciário por meio do controle de constitucionalidade

51 Cf. CAMpllongo, Celso Fernandes. Política, sistema jurídico e decisão judicial. São Paulo: Max Limonad, 2002, p. 61.

52 MELLO FILHO, José Celso de. "O Supremo Tribunal Federal na Constituição de 1988: espaço de construção de uma jurisprudência de liberdades". In: BRASIL. Supremo Tribunal Federal (STF). A Constituição de 1988 na visão dos Ministros do Supremo Tribunal Federal. Brasília: Secretaria de Documentação/STF, 2013, p. 17-60. 
acarretaram no enfraquecimento do Legislativo, justamente o poder que detém a maior legitimidade democrática ${ }^{53}$.

Beçak chama a atenção para outra questão importante relativa ao ativismo judicial: a ausência de legitimidade popular dos magistrados. O fato de os juízes não ocuparem cargo eletivo seria um impeditivo inicial à exacerbação da competência constitucional do Judiciário ${ }^{54}$. Fabiana Luci de Oliveira, nesse ponto, destaca que a ausência de legitimidade eletiva por parte dos Ministros do STF tem dois lados diametralmente opostos. Por um lado, os julgadores são imunes a interesses partidários, já que não têm a preocupação de participar e de vencer pleitos eleitorais. Por outro lado, quando decidem questões de caráter político, são considerados parciais ${ }^{55}$.

\subsection{Causas do surgimento do fenômeno do ativismo judicial no Brasil}

Entendido o contexto histórico e feita a conceituação dos fenômenos do ativismo judicial e da judicialização da política, devemos entender os motivos para o ativismo ocorrer também aqui no Brasil.

Primeiramente, o modelo constitucional brasileiro, desde a Constituição de 1934, tem como característica a adoção de um modelo de Estado social. o

53 Cf. BEÇAK, Rubens. "A separação dos poderes, o tribunal constitucional e a 'judicialização da política'". In: Revista da Faculdade de Direito da Universidade de São Paulo, v. 103, jan./dez. 2008, p. 325-336.

54 Cf. BEÇAK, Rubens. "A separação dos poderes, o tribunal constitucional e a 'judicialização da política'". In: Revista da Faculdade de Direito da Universidade de São Paulo, v. 103, jan./dez. 2008, p. 325-336.

55 Cf. OLIVEIRA, Fabiana Luci de. Justiça, profissionalismo e política: - STF e o controle de constitucionalidade das leis no Brasil. Rio de Janeiro: Editora FGV, 2011, p. 246. 
advento da Constituição de 1988 não mudou esse paradigma. Nota-se com a leitura do texto constitucional a evidente preocupação do constituinte na garantia de direitos fundamentais de primeira (civis e políticos) e segunda geração (sociais e econômicos). Este modelo faz com que recaia no Judiciário as expectativas populares para trazer maior celeridade no cumprimento dos objetivos dispostos no texto constitucional ${ }^{56}$.

O Welfare State, modelo de Estado adotado no Brasil, tem como característica uma forte inflação legislativa. Tal fenômeno ocorre diante do fato de que a maior preocupação com direitos sociais e econômicos garantidos aos cidadãos tem como consequência o maior número de promulgação de leis pelo Legislativo. Essa inflação legislativa traz maiores possibilidades de crescer também o número de discussões envolvendo a utilização dos sistemas de controle de constitucionalidade. Estes sistemas garantem ao Judiciário maior proximidade com a função legislativa, mesmo no exercício da função jurisdicional. Corrobora com a afirmação Elival da Silva Ramos, in verbis:

"A principal razão para tanto está na maior proximidade do controle de constitucionalidade, assim efetuado, do exercício da função legislativa, ainda que se trate, como já assinalado, de função jurisdicional. Com efeito, quer em uma hipótese como noutra, a decisão judicial sobre a validade da lei é emitida com efeitos gerais, ou erga omnes; de outra parte, quer no controle concentrado, quer no controle abstrato em sistema difuso, registrase a tendência a se admitir a modulação dos efeitos temporais das decisões sancionatórias da inconstitucionalidade; finalmente, a jurisdição constitucional, assim desenvolvida, interfere diretamente no conteúdo dos atos legislativos controlados. O exercício da

\footnotetext{
56 No mesmo sentido, Elival da Silva Ramos afirma que "Ao Poder Judiciário deveria caber, nesse modelo, o controle jurídico da atividade intervencionista dos demais Poderes. No entanto, sobre ele também recaem as expectativas e pressões da sociedade no sentido da mais célere possível consecução dos fins traçados na constituição, incluindo a imediata fruição de direitos sociais ou a extensão de benefícios". (In: Ativismo judicial: parâmetros dogmáticos. São Paulo: Saraiva, 2010, p. 271.).
} 
fiscalização de constitucionalidade, nas condições apontadas, é fator desencadeante do ativismo judiciário na medida em que o órgão de controle perceba tornar-se menos nítida a distinção entre legislação e jurisdição ${ }^{57 "}$.

Neste contexto, podemos citar o fato de que o fenômeno do ativismo judicial ocorre com cada vez mais força em vários países do globo, e no Brasil não é diferente. Diante de uma Constituição que tem como princípio a prevalência da dignidade humana, prevendo em diversos dispositivos o respeito aos direitos fundamentais, não haveria como o Poder Judiciário não se envolver nessa busca. Nesse sentido, Sérgio Pompeu de Freitas Campos afirmou que

“(...) a sociedade brasileira estaria internalizando o processo de judicialização da política característico dos Estados contemporâneos.

(...)

Considerando o déficit de cidadania característico da sociedade brasileira, a consolidação da democracia entre nós não poderia depender apenas dos métodos tradicionais de formação da opinião e da vontade, historicamente dominados pelo clientelismo e pela patronagem. Assim, a implementação da República delineada pela CR 1988 envolve a garantia jurisdicional dos direitos fundamentais e a efetiva participação da sociedade no desenvolvimento da interpretação da Constituição ${ }^{58, "}$

O terceiro fator que explica a presença do ativismo judicial no Brasil é o advento de teorias neoconstitucionalistas. Para Elival da Silva Ramos, esta corrente, apesar da grande influência no meio acadêmico jurídico brasileiro, não tem razão de ter tamanha popularidade. Primeiramente, o autor aponta que a premissa da teoria em questão, de que a Constituição ganhou recentemente supremacia formal, está equivocada. A rigidez das Constituições republicanas brasileiras, por exemplo, evidenciam que sempre houve no Brasil uma maior força

57 RAMOS, Elival da Silva. Ativismo judicial: parâmetros dogmáticos. São Paulo: Saraiva, 2010, p. 277.

58 CAMPos, Sérgio Pompeu de Freitas. Separação dos poderes na jurisprudência do Supremo Tribunal Federal. Porto Alegre: Sergio Antonio Fabris Ed., 2007, p. 237. 
normativa por parte do texto constitucional. Ademais, o juiz, ao julgar, sempre deve estar vinculado à norma constitucional, infraconstitucional, com especial atenção à distribuição de competências constitucionais, à separação de poderes e ao princípio democrático ${ }^{59}$.

A sistemática política brasileira também pode ser apontada como um dos fatores catalisadores do ativismo judicial no Brasil. O enfraquecimento do Legislativo, somado à grande força do Executivo, que consegue aprovar a maior parte de seus projetos de lei apresentados, e aliando, ainda, ao novo protagonismo do Judiciário fazem com que a função jurisdicional possa ser exercida de modo exacerbado.

Por fim, é forçoso lembrar que o STF também tem assumido funções constitucionais de atividade normativa. Essas funções novas também aproximam o supremo da atividade legiferante, propiciando maiores condições para a sobrevivência do ativismo judicial. Elival Ramos cita como exemplo a adoção do posicionamento concretista nos julgamentos de mandados de injunção e a possibilidade de editar súmulas com conteúdo vinculante aos demais órgãos do Judiciário e também à administração pública direta e indireta nas esferas federal, estadual e municipal ${ }^{60}$.

Conclui-se que o novo protagonismo do Judiciário, em especial do STF, adveio principalmente das mudanças trazidas pelo texto constitucional de 1988. Desde então, O STF deixou de ser um mero coadjuvante no panorama político brasileiro, passando a ser protagonista, com

\footnotetext{
59 Cf. RAMOS, Elival da Silva. Ativismo judicial: parâmetros dogmáticos. São Paulo: Saraiva, 2010, p. 280.

60 Cf. RAMOS, Elival da Silva. Ativismo judicial: parâmetros dogmáticos. São Paulo: Saraiva, 2010, p. 300.
} 


\author{
ativismo judicial ou não. O novo papel do STF é bem \\ destacado por Oscar Vilhena Vieira, in verbis:
}

"Percorrido esse longo caminho, podemos concluir que a partir das mudanças impostas pela Constituição de 1988, o Supremo Tribunal Federal viu-se obrigado a assumir o papel de árbitro da política nacional, neutralizando conflitos desagregadores e garantindo a continuidade e a harmonia do sistema político, exercendo uma espécie de Poder Moderador - guardadas as enormes distinções - do império, exercido em diversos momentos da vida republicana brasileira, pelas forças armadas. Se isto for verdade, temos uma enorme evolução de nosso sistema político, não apenas pelo fato de ser o Supremo Tribunal Federal um órgão republicano e civil, mas especialmente pela sua obrigação de deliberar tendo em vista o texto da Constituição, portanto, pactuado pela sociedade brasileira como meta-regra de nosso sistema político. ${ }^{61,}$

Vilhena, porém, pondera, afastando a
possibilidade de ativismo judicial na atuação do STF,
conforme trecho adiante:

Ao assegurar a vontade da Constituição o Supremo Tribunal Federal realiza o ideal do governo das leis. Caso se afaste da vontade da Constituição, substituindo-a pela de seus próprios Ministros, estará agindo ilegitimamente, pois afinal não foram eleitos para assumir esse tipo de função e sequer a Constituição assegurou ao tribunal tais atribuições. Ao Supremo Tribunal Federal, no entanto, cabe a última palavra. Daí a sua enorme responsabilidade" ${ }^{\prime 62}$.

\title{
2.5. Ativismo judicial: análise de casos
}

\author{
Analisado o fenômeno do ativismo judicial \\ no Brasil, trazemos agora dois exemplos de decisões \\ judiciais na seara político-eleitoral brasileira no intuito \\ de demonstrar que o ativismo judicial, surge até \\ corriqueiramente no cenário jurisdicional pátrio.
}

\footnotetext{
61 VIEIRA, Oscar Vilhena. Supremo Tribunal Federal: jurisprudência política. São Paulo: Malheiros, $2^{a}$ ed., 2002, p. 233.

62 VIEIRA, Oscar Vilhena. Supremo Tribunal Federal: jurisprudência política. São Paulo: Malheiros, $2^{a}$ ed., 2002, p. 233.
} 
A história do Supremo Tribunal Federal é recheada de exemplos de questões político-eleitorais sob seu julgamento. Um dos episódios mais relembrados da atuação no Judiciário no campo político brasileiro é o da cassação do registro do PCB.

Após a queda do regime do Estado Novo, logo após o final da Segunda Guerra Mundial, em 1945, foram convocadas eleições diretas à Presidência da República e para a formação de uma Assembleia Nacional Constituinte. Nessa eleição, no qual se tornou presidente o General Eurico Gaspar Dutra (PSD), apoiador do regime de Getúlio Vargas, o Partido Comunista Brasileiro amealhou 10\% do eleitorado na corrida para o Palácio do Catete. Na eleição legislativa, O PCB conseguiu eleger catorze deputados e um senador, para o desgosto de membros das Forças Armadas e de vários setores da sociedade civil.

Pouco tempo após a posse de Dutra na Presidência da República, membros do PTB apresentaram na Justiça Eleitoral denúncia contra as atividades do PCB e requerendo, consequentemente, a cassação do registro da agremiação comunista. Suas alegações residiam no fato de o PCB ser braço de organização internacional baseada na ideologia marxista-leninista e, portanto, contrário às recentes instituições democráticas nacionais ${ }^{63}$.

A polêmica tramitação deste pedido na Justiça Eleitoral não tardou a chegar à Assembleia Constituinte. E houve resultados práticos: foi aprovado dispositivo constitucional (art. 141, parágrafo 13, Constituição de 1946) que proibia o funcionamento de

63 Cf. Costa, Emília Viotti da. O Supremo Tribunal Federal e a construção da cidadania. São Paulo: Editora UNESP, $2^{a}$ ed., 2006, p. 114 . 
partido político cujo programa contrariasse o regime democrático. No texto, constava também a competência da Justiça Eleitoral para a cassação do registro de partidos políticos (art. 119, I, Constituição de 1946).

O TSE decidiu, por maioria, cassar O registro do PCB. Nova questão polêmica surgiu em decorrência desta decisão: qual era a situação jurídica dos congressistas filiados ao PCB? A cassação dos mandatos foi decretada pelo Congresso Nacional em 7 de janeiro de 1948, mesmo após intensa oposição até de membros da UDN, partido de caráter conservador ${ }^{64}$.

O STF manifestou-se sobre a celeuma decorrente da cassação do registro do PCB por três vezes. A manifestação de maior importância ocorreu em sede de mandado de segurança. O líder do PCB, Luís Carlos Prestes, impetrou o remédio constitucional no Supremo visando à preservação dos mandatos dos filiados de seu partido. Suas alegações, porém, não convenceram os ministros do STF. A posição vencedora na corte foi a de que o regime democrático iniciado em 1946 tinha como base a formação dos partidos políticos. O eleitor, ao exercer seu direito no pleito, "não designava um candidato incumbido de substituir sua vontade pela dele; não votava em certo indivíduo, votava em uma política, um programa, um partido65".

Podemos destacar também outra série de decisões que mexeram com o sistema politico brasileiro durante o regime democrático de 1946, encerrado com o golpe

\footnotetext{
64 Cf. Costa, Emília Viotti da. O Supremo Tribunal Federal e a construção da cidadania. São Paulo: Editora UNESP, $2^{a}$ ed., $2006, p$. 116 .

65 CostA, Emília Viotti da. O Supremo Tribunal Federal e a construção da cidadania. São Paulo: Editora UNESP, 2a ed., 2006, p. 118.
} 
militar de 1964. A sucessão presidencial de 1955 foi alvo de intensa discussão no STF. Após a vitória de Juscelino Kubitschek (PSD) sem atingir a maioria absoluta dos votos, houve grande contestação do resultado no meio político e nas Forças Armadas. Ressalte-se que a Constituição de 1946 não previa a possibilidade de segundo turno nas eleições para o Poder Executivo, bastando ao primeiro colocado na corrida eleitoral atingir a maioria simples dos votos para ser empossado no cargo em disputa.

Entre a eleição e a posse, o então presidente da República João Café Filho teve de se afastar do cargo por motivos médicos. Assumiu em seu lugar o presidente da Câmara dos Deputados, Carlos Luz. Luz tentou impedir a posse de Kubitschek e, por isso, foi afastado, assumindo a presidência até a posse de Juscelino o presidente do Senado Federal, Nereu Ramos.

Os afastamentos de Café Filho e de Carlos Luz foram objeto de discussões jurisdicionais no STF. Rubens Beçak explica que o Congresso afastou os dois pelo mesmo motivo: a permanência de Luz ou a reassunção de Café Filho após sua recuperação médica seria ruim para o sistema político brasileiro, que estava prestes a empossar o novo presidente constitucionalmente eleito. Segue o trecho que resume o pensamento de Beçak:

"O que ocorreu no Brasil de 1955 foi extremamente similar. O legislador, convencido da incapacidade, da inability, dos presidentes de então, deu-os por impossibilitados de reassumir seus cargos. A reassunção do poder por eles, não se duvidava então, ou ao menos a maioria não tinha dúvidas, constituiria um desastre para as instituições democráticas.

Assim, não ocorrendo vaga, eis que nenhum motivo para sua verificação existia, só restou ao legislador o socorro da figura do 
impedimento, aplicado de forma que não se reconhecia presente no texto constitucional ${ }^{66}$,"

Provocado, O STF optou por uma solução política. O Judiciário, seguindo a decisão proferida pelo Poder Legislativo, adotou postura consequencialista e também entendeu que o melhor a ser feito, diante do panorama político, era manter o afastamento de Café Filho e aguardar a posse de Kubitschek no intuito de acalmas a situação política e impedir um possível golpe militar ${ }^{67}$.

Após o surgimento de novo regime democrático no Brasil com advento da Constituição de 1988, como já estudado, a suprema corte brasileira ganhou ainda mais espaço no panorama político brasileiro. Na seara político-eleitoral não foi diferente. Há diversos temas possíveis de serem enfatizados no intuito de demonstrar que - STF, uma vez provocado, se manifestou no âmbito do fenômeno da judicialização da política. Escolhemos dois desses exemplos para uma análise pormenorizada.

O primeiro deles trata da proibição do uso de imagens externas na propaganda eleitoral. A lei que regeu as eleições gerais de 1994 previa a vedação ao uso de imagens captadas fora de estúdio na propaganda eleitoral. Essa proibição foi apontada por especialistas em marketing político como extremamente prejudicial a um candidato específico na luta pela Presidência da República: Luiz

\footnotetext{
66 BEÇAK, Rubens. Sucessão presidencial de 1955: aspectos políticos e jurídicos. São Paulo: Editora Juarez de Oliveira, 2003, p. 30.

67 No mesmo sentido, Rubens Beçak (Sucessão presidencial de 1955: aspectos políticos e jurídicos. São Paulo: Editora Juarez de Oliveira, 2003, p. 38), in verbis: "Houve, em nosso pensar, um entendimento tácito do Legislativo e do Judiciário no sentido da relativa flexibilidade da norma constitucional à vista do perigo maior que a todos afigurava-se, a possibilidade de um golpe contra a posse da chapa vencedora das eleições de outubro de 1955".
} 
Inácio Lula da Silva (PT). Seu partido ajuizou ação direta visando à declaração de inconstitucionalidade da vedação contida na lei eleitoral. Como veremos no subitem a seguir, - STF manteve a constitucionalidade da norma.

A segunda análise de caso tratará da fixação do número de cadeiras nas Câmaras Municipais à exata proporção ao número de habitantes de cada Município brasileiro. Ao contrário da primeira, O STF decidiu a questão em sede de recurso extraordinário, ou seja, por meio do controle de constitucionalidade difuso. Após sua decisão, visando a conferir efetividade nacional a seu julgamento, O STF determinou que O TSE deveria baixar resolução normativa contendo as disposições gerais para os Municípios adaptarem-se à nova realidade jurídica da questão.

O exame das decisões do STF nestes dois exemplos, retirados de duas modalidades diferentes de controle de constitucionalidade, demonstrarão que a judicialização da política continua na pauta do dia do Congresso, do Executivo e obviamente do Supremo Tribunal Federal.

\subsubsection{Proibição do uso de imagens externas na propaganda eleitoral}

A primeira grande polêmica judicial envolvendo a legislação político-eleitoral brasileira após a promulgação da Constituição de 1988 foi a questão da proibição do uso de imagens externas na propaganda eleitoral nas eleições de outubro de 1994. 
Esta decisão, proferida pelo supremo Tribunal Federal em $1^{\circ}$ de julho de 1994, ou seja, dias antes do início do período eleitoral que culminaria com as eleições para presidente da República, governadores, deputados federais, estaduais e distritais, bem como ao Senado Federal, pode ser considerada um verdadeiro marco no que tange o fenômeno da judicialização da política.

Este notório leading case demonstra que, a partir de então, os partidos políticos e seus filiados procurariam resolver questões nas fileiras do Poder Judiciário, em especial no Tribunal Superior Eleitoral e no Supremo Tribunal Federal.

o julgamento da ação direta de inconstitucionalidade n. 956-7/DF é considerada um marco pelo fato de a mudança perpetrada pelo Congresso Nacional na legislação eleitoral com o intuito de proibir a exibição de gravações externas, montagens ou trucagens na propaganda eleitoral na televisão ter afetado diretamente um candidato à presidência da República no certame de então.

Para a análise do ocorrido, será necessária uma apreciação do contexto político envolvido, para que depois a argumentação trazida à baila pelas partes possa servir de demonstração da importância dessa decisão para uma melhor avaliação do fenômeno ora estudado no presente trabalho.

A Lei n. 8.713, de $1^{\circ}$ de outubro de 1993, continha referida proibição no $\$ 1^{\circ}$ do art. $76^{68}$. Essa

68 "Art. 76. Os programas destinados à veiculação no horário gratuito pela televisão devem ser realizados em estúdio, seja para transmissão ao vivo ou pré-gravados, podendo utilizar música ou jingle do partido, criados para a campanha eleitoral. 
proibição foi vista por especialistas e acadêmicos na área de propaganda e marketing eleitoral como uma forma de prejudicar o oposicionista Partido dos Trabalhadores (PT) e seu possível candidato ao Palácio do Planalto nas eleições de outubro de 1994, Luiz Inácio Lula da Silva ${ }^{69}$.

Para Luis Felipe Miguel, a efetividade da propaganda eleitoral nas eleições de 1994 foi afetada com a mudança normativa acima referida ${ }^{70}$, pois a lei vetou: (i) a presença de convidados nos programas; (ii) a exibição de cenas produzidas fora de estúdio; e (iii) a utilização de trucagens ${ }^{71}$.

$\$ 1^{\circ}$. Nos programas a que se refere este artigo, é vedada a utilização de gravações externas, montagens ou trucagens".

69 No mesmo sentido, pode-se citar, inicialmente, Luis Felipe Miguel, que asseverou que "uma análise muito difundida viu na mudança da legislação uma manobra para atingir o candidato do PT, Lula, pois era conhecida a intenção de fazer suas viagens pelo país - as 'caravanas da cidadania' - um dos carros-chefe da propaganda da TV". ("Discursos cruzados: telenotícias, HPEG e a construção da agenda eleitoral". In: Sociologias, ano 6, n. 11, jan/jun 2004, p. 245-246). No mesmo sentido, Elizabeth Rondelli e Maria Helena Weber afirmaram que o art. 76, \$ 1, da Lei das Eleições de 1994 era um "retrocesso em um país premiado internacionalmente por sua propaganda criativa e ousada". Ademais, apontaram as autoras que a vedação às imagens externas poderia "beneficiar candidatos que tenham grande capacidade de expressão verbal e, por isso, o seu preparo poderá ser feito até em cursos de teatro, onde aprenderão frases e gestos persuasivos. Sai a política que dialoga com o real, e o referencia nas cenas externas, e entra o político personalista que dialoga olhos nos olhos com seu eleitor, simulando intimidades". ("Ensaio das eliminatórias: os media e o campeonato eleitoral", In: Comunicação \& Política, n. 1, ago./nov. 1994, p. 41-52).

70 Corrobora com esta análise Afonso de Albuquerque e Marcia Ribeiro Dias, ao atestarem que a proibição da utilização de imagens externas na propaganda eleitoral em 1994 se tratou de uma "exceção pontual" que implicou na "marginalização do HGPE na campanha eleitoral, o que favoreceu a candidatura de Fernando Henrique Cardoso, apresentado pela imprensa como o grande responsável pelo sucesso do Plano Real". ("Propaganda política e a construção da imagem partidária no Brasil: considerações preliminares". Encontro Anual da Associação Nacional dos Curso de Pós-Graduação em Ciências Sociais (ANPOCS), $26^{\circ}$, Caxambu: Anpocs, 2002 (mimeo).

71 Nesta terceira mudança, o autor afirma que a lei se utilizou de um "termo impreciso, uma vez que, a rigor, a própria edição já é uma trucagem, a trucagem básica da produção audiovisual". "Discursos cruzados: telenotícias, HPEG e a construção da agenda eleitoral". In: Sociologias, ano 6, n. 11, jan/jun 2004, p. 245. 
Diante da legislação acima exposta, o Partido dos Trabalhadores, com base no inciso VII do art. 103 da Constituição, ajuizou ação direta de inconstitucionalidade no Supremo Tribunal Federal, alegando que referido dispositivo da legislação eleitoral era inconstitucional, uma vez que afrontava o princípio da liberdade de informação e de imprensa, ambos previstos nos parágrafos $1^{\circ}$ e $2^{\circ}$ do art. 220 da Constituição ${ }^{72}$.

$\mathrm{Na}$ petição inicial, O $\mathrm{PT}$ resumiu suas alegações ao argumentar que

“(...) a propaganda eleitoral gratuita, de um lado, tem o sentido de garantir tratamento isonômico entre as forças políticas, impedindo que as forças econômicas se imponham, e, de outro, possibilita o acesso às informações, para facilitar a escolha soberana e o exercício efetivo da cidadania, de sorte que a proibição do uso de imagens externas limita drasticamente a comunicação do pensamento e a livre circulação da informação, afrontando a liberdade constitucional de informa e de receber informações" ${ }^{\text {"73 }}$.

A Advocacia Geral da União, ao exercer seu papel constitucional de "defensora" da constitucionalidade da lei, utilizou-se, paradoxalmente, da mesma argumentação empreendida pelo PT ao expressar que a vedação do dispositivo legal em comento na verdade impedia que os partidos políticos com mais recursos utilizassem dos

\footnotetext{
72 "Art. 220. A manifestação do pensamento, a criação, a expressão e a informação, sob qualquer forma, processo ou veículo não sofrerão qualquer restrição, observado o disposto nesta Constituição.

$\$ 1^{\circ}$ - Nenhuma lei conterá dispositivo que possa constituir embaraço à plena liberdade de informação jornalística em qualquer veículo de comunicação social, observado o disposto no art. 5º, IV, V, X, XIII e XIV.

$\$ 2^{\circ}-E^{\circ}$ vedada toda e qualquer censura de natureza política, ideológica e artística."

73 Marcelo Bolshaw Gomes sustenta que as restrições impostas pela Lei das Eleições de 1994 "acabaram por prejudicar a estratégia de campanha de Lula para TV, que esperava poder utilizar os vídeos da Caravana da Cidadania, suas viagens pelo interior do país". ("A imagem pública de Lula e eleições presidenciais brasileiras (1989/2002). In: I Congresso da COMPOL (Associação Brasileira de Pesquisadores de Comunicação e Política). Salvador: UFBA, 2006, p. 8.
} 
recursos vetados pela lei, fato este que garantiria maior igualdade de condições entre as candidaturas.

A Procuradoria-Geral da República manifestou-se no sentido da improcedência da ação. Seu primeiro e principal argumento baseava-se no fato de não haver qualquer óbice no artigo contestado em relação aos \$\$ $1^{\circ}$ e $2^{\circ}$ do art. 220 da Constituição. Nestes dispositivos, a Constituição garante a todos os brasileiros a liberdade de imprensa, de informação e de opinião jornalística. Já o $\$$ $1^{\circ}$ do art. 76 da Lei 8.713/1993 tratava de limitação à publicidade política gratuita.

A PGR também argumentou que a União, conforme previsão do inciso I do art. 22 da Constituição que garante sua competência privativa de legislar em matéria de direito eleitoral, pode estabelecer restrições visando a garantir o acesso idôneo dos partidos políticos ao horário gratuito no rádio e na televisão (art. 17, \$ $3^{\circ}$, (RFB) .

Nesse ínterim, a PGR enfatizou as duas funções jurídicas da propaganda político-eleitoral na televisão, quais sejam: "de um lado, garantir tratamento isonômico aos partidos políticos e aos candidatos concorrentes na comunicação ao grande público de seus programas, propostas e ideias e, de outro, correlativamente, velar para que as informações, levadas através das forças políticas em disputa, não sejam desvirtuadas pelas influências do poder econômico ou pela utilização de recursos tendentes a falsear as tendências do eleitorado ou a expor ao ridículo ou à degradação partidos ou candidatos ${ }^{74 "}$.

74 ADI 956-7/DF, Rel. Min. Francisco Rezek, j. 0107.1994. 
Por fim, destaca mais uma vez a PGR o fato de a regra impugnada pelo PT ter por finalidade afastar a influência do poder econômico na propaganda eleitoral, ao impedir "a utilização de recursos técnicos de áudio e vídeo sofisticados e dispendiosos, realizados por grandes empresas de publicidade, que constituiria privilégio de alguns poucos partidos políticos, inatingíveis pelos demais ${ }^{75 \prime}$.

O Ministro Relator inicia seu voto relembrando que a norma em debate era resultado de um projeto de autoria do então deputado federal José Dirceu $(\mathrm{PT} / \mathrm{SP})$. Destaca o julgador, porém, que este fato não influenciaria de modo algum seu julgamento.

Em sua breve análise, o Ministro Francisco Rezek decide pela improcedência da ação direta, ao determinar que o horário gratuito não tem sede constitucional, já que a Constituição prevê, no $\$ 3^{\circ}$ do art. 17, que cabe à lei estabelecer critérios para os partidos políticos utilizarem referido instituto.

No mesmo sentido, o Ministro Ilmar Galvão ressaltou que a matéria discutida não abarca a liberdade de manifestação prevista no art. 220 da Constituição. o Ministro Carlos Velloso clarifica a questão já apontada pelos outros dois julgadores: em se tratando de propaganda eleitoral gratuita, o dispositivo constitucional a ser debatido é o parágrafo $3^{\circ}$ do art. 17 , e não os $\$ \$ 1^{\circ}$ e $2^{\circ}$ do art. 220 .

75 ADI 956-7/DF, Rel. Min. Francisco Rezek, j. 01.07.1994. 
Nesse sentido, o dispositivo da lei eleitoral impugnado veio à tona exatamente para cumprir o mandamento constitucional relacionado. Assim, a proibição da utilização de imagens externas, trucagens ou montagens tem a finalidade de baratear a propaganda eleitoral. 0 \$ $3^{\circ}$ do art. 17 da Constituição garante o acesso dos partidos políticos à gratuidade dos horários partidário e eleitoral para o mesmo objetivo: garantir acesso a todos os partidos e candidatos, barateando a propaganda eleitoral ${ }^{76}$.

Já o Ministro Sepúlveda Pertence defende, em seu voto, que o dispositivo impugnado tem sim relação com o art. 220, \$\$ $1^{\circ}$ e $2^{\circ}$, da Constituição. Pertence, no entanto, destaca que a proibição em questão não se tratava de uma reedição da Lei Falcão ${ }^{77}$, mas sim "assegurar a eficácia da própria ideia de acesso gratuito ao rádio e à televisão, que é de inspiração evidentemente isonômica ${ }^{78 "}$. Acompanharam a maioria os Ministros Moreira Alves e Néri da

\footnotetext{
76 o posicionamento do Min. Carlos Velloso acompanha o da maioria. Ele, porém, trouxe alguns aspectos que devem ser enfatizados, conforme trecho a seguir: "Trata-se, a norma constitucional indicada - $\$ 3^{\circ}$ do art. 17 - de norma de eficácia limitada, dependente de normatização ulterior, normatização que veio com a Lei 8.713, de 1993, art. 76, § $1^{\circ}$. Essa norma infraconstitucional, que confere eficácia à norma constitucional referida, tem um bom sentido: baratear, tornando acessível a todos os candidatos e partidos, a propaganda eleitoral, assim afastando da pugna eleitoral as nefastas influências do poder econômico. É que os candidatos com mais dinheiro poderiam fazer vídeos maravilhosos, programas requintados, mediante o pagamento de vultosas somas de dinheiro, em detrimento dos mais pobres. (...) A Lei 8.713, de 30.9.93, quer evitar o falseamento da verdade mediante programas caríssimos, e que os truques, as trucagens, as montagens e os recursos técnicos da mídia eletrônica costumam transformar imagens, superestimar conceitos, projetar imagens falsas para um público desarmado, que espera que os candidatos apresentam as suas ideias, mostrem as suas exatas personalidades. Sob esse aspecto, a lei é boa." .

77 A Lei n. 6.339, de $1^{\circ}$ de julho de 1976, conhecida por "Lei Falcão" por ter sido criada pelo então Ministro da Justiça do governo Ernesto Geisel, Armando Falcão, caracterizou-se por engessar sobremaneira a propaganda eleitoral, ao determinar que os candidatos somente poderiam apresentar seus respectivos currículos, seu número de legenda e uma fotografia com seu rosto. O intuito dessa lei era, na prática, prejudicar as chances eleitorais dos candidatos de oposição ao regime militar.

${ }_{78}$ ADI 956-7/DF, Rel. Min. Francisco Rezek, j. 01.07.1994.
} 
Silveira, ambos apresentando os mesmos argumentos acima debatidos .

Dois Ministros, porém, julgaram a ação direta procedente. O Min. Marco Aurélio reconheceu, ao contrário da maioria, a ofensa ao princípio constitucional da liberdade de manifestação, pensamento e informação. Seu voto ressalta que a vigência do dispositivo eleitoral ora em debate impediria a produção de programas que revelassem a realidade nacional, seus "grandes contrastes" e as "desigualdades existentes"

O Min. Celso de Mello também votou pela procedência da ação. Primeiramente, classifica a regra legal adotada pelo Congresso Nacional como "solução autoritária". O hoje Ministro Decano sustenta seu voto em direto embate com a argumentação trazida pelos Ministros que entenderam pela improcedência da ação. Ele reconhece a possibilidade de abuso por parte de candidatos e partidos políticos. No entanto, Mello crê que a liberdade de manifestação e pensamento, principalmente quando no exercício partidário-eleitoral, trata-se de valor indispensável para a sustentação da ordem democrática.

Nesse sentido, o Mello deixa evidente que quem abusar no exercício da liberdade de manifestação deverá ser punido a posteriori. Entretanto, a possibilidade de haver abuso não serve de justificativa para uma

"reação antecipada do Poder Público (...) a conferir ao Estado a inaceitável possibilidade de impor restrições prévias ao exercício dessa eminente liberdade pública que se reflete no direito de a agremiação partidária expor, de modo pleno, sem quaisquer condicionamentos pertinentes à utilização de recursos técnicos ou cênicos, as informações que entender essenciais à compreensão e à divulgação de seu programa de ação política ${ }^{80 "}$.

\footnotetext{
79 ADI 956-7/DF, Rel. Min. Francisco Rezek, j. 010.07.1994.

80 ADI 956-7/DF, Rel. Min. Francisco Rezek, j. 010.07.1994.
} 
No final, a maioria do Pleno do STF decidiu pela improcedência da ação direta ajuizada pelo PT. Essa ação, no entanto, trouxe à baila, conforme aqui demonstrado, debates acadêmicos sobre a influência que uma mudança tão específica e pontual na legislação eleitoral pode surtir efeitos em uma campanha eleitoral.

Ao mesmo tempo, essa decisão tornou-se um verdadeiro marco inicial de um fenômeno até então pouco conhecido no Brasil, fenômeno este que posteriormente seria verificado de modo mais constante, qual seja: a busca de atores do cenário político brasileiro de resolução de conflitos no Poder Judiciário.

$\mathrm{Na}$ decisão ora debatida, o STF foi provocado para exercer seu papel de guardião da Constituição por meio do controle de constitucionalidade concentrado. Ver-se-á que, anos depois, diferentemente, outros meios previstos no ordenamento jurídico brasileiro serviram como catalisador de resolução de demandas e debates legislativos no Poder Judiciário, fato este que culminou no intenso debate do fenômeno do ativismo da Justiça Eleitoral.

\subsubsection{Proporcionalidade entre $\circ$ número de cadeiras nas Câmaras Municipais e a população do Município}

O Supremo Tribunal Federal tem, entre diversas outras competências constitucionais, a de julgar, em sede de recurso extraordinário, recursos interpostos por suposta violação a dispositivos constitucionais na decisão recorrida. 
Em 24 de março de 2004, o STF julgou o Recurso Extraordinário n 197.917-8/SP, interposto pelo Ministério Público do Estado de São Paulo, contra acórdão proferido pelo Tribunal de Justiça de São Paulo em sede de ação civil pública ajuizada pelo MPE-SP com o objetivo de reduzir o número de vereadores da Câmara Municipal de Mira Estrela, São Paulo, município este que, na época, tinha 2.651 (dois mil, seiscentos e cinquenta e um) habitantes.

A alegação do Parquet consistia no fato de 0 art. $6^{\circ}$ da Lei Orgânica do referido Município não obedecer à proporção estabelecida no art. 29, inciso IV, alínea "a" 81 , então vigente da Constituição. Este fato, segundo O MPE-SP, acarretaria prejuízo ao erário local.

o juízo de primeiro grau julgou a ação civil pública parcialmente procedente, ao reconhecer a inconstitucionalidade da norma municipal impugnada. Ademais, decretou a extinção dos mandatos "excedentes", bem como determinou a restituição dos valores recebidos pelos vereadores a partir da sentença. Indeferiu, porém, o pedido de devolução dos subsídios recebidos pelos edis antes da publicação da sentença.

O Tribunal de Justiça de São Paulo, ao julgar as apelações interpostas pelo Ministério Público Estadual e pela Câmara Municipal de Mira Estrela, reverteu a sentença, julgando a ação improcedente, em respeito ao

81 "Art. 29. O Município reger-se-á por lei orgânica, votada em dois turnos, com o interstício mínimo de dez dias, e aprovada por dois terços dos membros da Câmara Municipal, que a promulgará, atendidos os princípios estabelecidos nesta Constituição, na constituição do respectivo Estado e os seguintes preceitos:

$(\ldots)$

IV - número de Vereadores proporcional à população do Município, observados os seguintes limites:

a) mínimo de nove e máximo de vinte e um nos Municípios de até um milhão de habitantes;". 
art. $2^{\circ}$ da Constituição ${ }^{82}$, que trata do princípio da separação dos poderes.

O Ministério Público do Estado de São Paulo interpôs recurso extraordinário, com fundamento nas alíneas "a" e "c" do art. 102 da Constituição83, alegando ofensa do acórdão da corte Paulista ao disposto no art. 29, inciso IV, da CRFB.

O Ministro Maurício Corrêa, relator do recurso, ao proferir seu voto, entendeu que a Constituição, ao determinar, no inciso IV do art. 29, que a quantidade de cadeiras nos Legislativos Municipais deve ser proporcional à população do Município, dispôs que a "proporcionalidade aritmética" é a "mais lídima resposta à exigência constitucional" ${ }^{84}$.

$\mathrm{Na}$ tese do Relator, que foi a vencedora, a hipótese de interpretar o texto no sentido de que foi disposto o número mínimo e máximo de vereadores, cabendo a cada Câmara Municipal, em sede de Lei Orgânica, decidir o número de vereadores naquele intervalo previsto nas alíneas do inciso IV do art. 29 pode "significar tudo, menos a proporcionalidade constitucionalmente reclamada, exigência clara e manifestamente definida na oração 'número de Vereadores proporcional à população do Município" .

\footnotetext{
82 Art. $2^{\circ}$ São Poderes da União, independentes e harmônicos entre si, 0 Legislativo, o Executivo e o Judiciário.

83 Art. 102. Compete ao Supremo Tribunal Federal, precipuamente, a guarda da Constituição, cabendo-lhe:

$(\ldots)$

III - julgar, mediante recurso extraordinário, as causas decididas em única ou última instância, quando a decisão recorrida:

a) contrariar dispositivo desta Constituição;

$(\ldots)$

c) julgar válida lei ou ato de governo local contestado em face desta Constituição.

${ }^{84} \mathrm{RE}$ n. 197.917/SP. Rel. Min. Maurício Corrêa, j. 24.03.2004.
} 
Ressalte-se que o Supremo já havia sido provocado nesta seara. No entanto, a decisão foi diametralmente diversa. Em respeito à autonomia municipal, O STF entendeu que a competência para a fixação do número de Vereadores era do Município ${ }^{85}$.

Após apresentar diversas planilhas com propostas aritméticas para determinar, de forma geral, intervalos numéricos dentro das hipóteses previstas nas alíneas do inciso IV do art. 29 e o respectivo número de vereadores, bem como outras planilhas demonstrando a incoerência de alguns Municípios com população pequena, mas grande representação legislativa ${ }^{86}$, assentou 0 Ministro Relator que a estrita proporcionalidade atende diversos outros princípios e regras constitucionais.

Primeiramente, dos princípios encartados no art. 37 da CRFB, quais sejam, legalidade, impessoalidade, moralidade, publicidade e eficiência, alguns deles seriam contemplados com a adoção da proporcionalidade estrita. A decisão teria como principal eficácia dirimir o "abuso com que as Câmaras Municipais elaboraram as Leis Orgânicas, prodigalizando o número de seus membros".

Ademais, houve também o afastamento da alegação da Câmara Municipal recorrida de ofensa à autonomia municipal, prevista nos arts. $1^{\circ}, 18$ e 29 da Constituição, uma vez que "na espécie fala mais alto o princípio maior resultante da própria Constituição, que

\footnotetext{
85 AGRRCL n. 488/TO, Rel. Min. Carlos Velloso, DJ 06.12.1996.

86 Entre diversos exemplos citados pelo Min. Maurício Corrêa, um deles demonstra de forma absolutamente evidente a questão concreta a ser resolvida. O Município de São Manuel/SP que, na época, tinha 38.271 habitantes, possuía 21 vereadores. Guarulhos/SP, com 972.197 habitantes, tinha o mesmo número de edis.
} 
submeteu os Municípios à regra da proporcionalidade entre o número de Vereadores e o de seus habitantes".

Por fim, o Ministro Relator reconhece 0 acerto da sentença, recompondo-a, determinando, em consequência, a diminuição de 11 (onze) para 9 (nove) vereadores.

O Ministro Gilmar Mendes, ao proferir seu voto-vista, enfatizou sua preocupação no que diz respeito aos efeitos da decisão a ser proferida pelo STF na hipótese. Primeiramente, lembrou o Min. Mendes que havia diversas outras ações com o mesmo objeto tramitando no Judiciário.

Depois, votou o Ministro Mendes, ao concordar com o teor proferido por Maurício Corrêa, pela aplicação da eficácia ex nunc da decisão, uma vez que a Legislatura em curso não poderia ser prejudicada.

o Min. Ayres Britto acompanhou a maioria, trazendo outro argumento. O fato de a constituição da República não ter dado aos Estados-membros a competência de fixar o número de deputados estaduais nas Assembleias Legislativas traz, como consequência lógica, o fato de que não há autonomia dos Municípios em fixar o número de cadeiras nas suas respectivas Câmaras Municipais.

Além de Gilmar Mendes e Ayres Britto, acompanharam $\circ$ Relator os seguintes Ministros: Nelson Jobim, Joaquim Barbosa, Cezar Peluso, Ellen Gracie, Carlos Velloso. 
A divergência foi inaugurada pelo Min. Sepúlveda Pertence. Ao relembrar que o Tribunal Superior Eleitoral também já havia debruçado sobre matéria ${ }^{87}$, preferiu enfatizar novamente o primado da autonomia municipal.

Destacou o Min. Pertence que a alegação trazida pelo Ministério Público do Estado de São Paulo de, no caso concreto, o Município de Mira Estrela ter onze, e não nove, Vereadores traria prejuízo ao erário público estaria superada, uma vez que a Emenda Constitucional n. 25, de 2000, alterou o inciso VI do art. 29, além de acrescentar um novo artigo ao texto constitucional (art. $29-\mathrm{A})$.

Nestes dois dispositivos, tratou-se da limitação constitucional aos subsídios recebidos pelos edis, bem como no que se refere à fixação de teto proporcional à despesa do Legislativo Municipal em relação à receita aferida pelo ente federativo.

Assim, concluiu o Min. Pertence, a EC n. 25/2000 "teve precisamente o sentido de submeter as despesas públicas locais a limites rígidos e variáveis conforme a grandeza do Município, sem lhe castrar a autonomia política na determinação do maior ou menor número de vereadores ${ }^{88 \prime \prime}$.

Acompanhando a divergência, o Min. Marco Aurélio ressaltou que, na hipótese, deveria prevalecer a autonomia municipal, não devendo o STF proceder à fixação do número de cadeiras nas Câmaras Municipais, pois não há

87 RMS n. 1.945, Rel. Min. Sepúlveda Pertence, DJ 11.06.1993.

$88 \mathrm{RE}$. 197.917/SP. Rel. Min. Maurício Corrêa, j. 24.03.2004. 
"acórdão do Supremo Tribunal Federal com contornos, com conteúdo, de verdadeira lei complementar". No mesmo sentido, votou o Min. Celso de Mello.

O fato que deve ser realçado nesse acórdão, seguindo o objetivo deste trabalho, resultou na observação feita pelo Min. Nelson Jobim por ocasião do final da leitura de todos os votos: o STF deveria esperar a Câmara Municipal de Mira Estrela/SP votar a mudança?

É forçoso ressaltar que, por se tratar de hipótese de controle de constitucionalidade difuso, esta decisão, em tese, não teria a envergadura de surtir efeitos sobre outros municípios, uma vez que os efeitos da decisão em sede de controle difuso são inter partes ${ }^{89}$.

Jobim trouxe essa preocupação pensando em uma possível consequência eleitoral: quantos candidatos cada partido ou coligação poderia lançar na eleição municipal de outubro de 2004? Ademais, externou essa preocupação com uma possível situação de dúvida presente em todo o país:

“Ora, se não tivermos, nesse período todo, uma solução desta questão em todo o País, tenho a impressão que vai haver uma enorme terrível dificuldade para o processo eleitoral que se realizará".

Assim, imediatamente sugeriu:

\footnotetext{
89 Renato Bernardi defende, por exemplo, que a decisão proferida pelo STF no referido recurso extraordinário deveria surtir efeitos somente ao Município de Mira Estrela, uma vez que a legislação prevê a possibilidade de controle de constitucionalidade concentrado pelo Supremo Tribunal Federal por meio de arguição de descumprimento de preceito fundamental (art. 102, \$ $1^{\circ}, \mathrm{CRFB}$ ). (In: "Número de vereadores: Resolução TSE $n^{\circ}$. 21.702/04 x Leis Orgânicas municipais". In: Boletim de Doutrina ADCOAS, v. 7, n. 14, 2004, p. 285-6).
} 
"Então, eu ponderaria, e aqui, evidentemente, presente está o Presidente do Tribunal Superior Eleitoral, que isso seria uma matéria a ser regulamentada pelo Tribunal Superior Eleitoral, para dar eficácia à situação e viabilizar a realização das eleições, porque, senão, vamos ter um imenso problema em relação a isso ${ }^{90,}$.

O Presidente do TSE, Min. Sepúlveda Pertence, respondeu que assim que publicado o acórdão, submeteria a questão ao TSE para decidir "como administrar - problema", pois embora o decidido tratasse de um caso concreto, era "preciso dar uma orientação uniforme a esse respeito para todo o País".

Diante da decisão do STF, O TSE editou, sob o disposto no inciso IX do art. 23 do Código Eleitoral, a Resolução n. 21.702/2004 ${ }^{91}$. Referida norma mencionava, em seu art. $1^{\circ}$, que a fixação do número de vereadores contida nela observava os critérios declarados no julgamento do recurso extraordinário supra.

Referida Resolução determinou que a população a ser considerada no cálculo seria a constante na estimativa do Instituto Brasileiro de Geografia e Estatística (IBGE) divulgada no ano anterior (parágrafo único do art. $1^{\circ}$ ).

Além disso, o art. $2^{\circ} 92$ previa que as Câmaras Municipais teriam até $1^{\circ}$ de junho de 2004 para se adequarem aos limites previstos no Anexo da Resolução ${ }^{93}$. Se

\footnotetext{
90 RE n. 197.917/SP. Rel. Min. Maurício Corrêa, j. 24.03.2004.

91 Resoluçãon. 21.702, de 2 de abril de 2004. Pet. n. 1.442/DF, Rel. Min. Sepúlveda Pertence.

92 "Art. $2^{\circ}$ Até $1^{\circ}$ de junho de 2004, o Tribunal Superior Eleitoral verificará a adequação da legislação de cada município ao disposto no art. $1^{\circ}$ e, na omissão ou desconformidade dela, determinará o número de vereadores a eleger."

93 O Anexo à Resolução n. $21.702 / 2004$ previa, em atendimento ao disposto na Constituição e com base na interpretação contida no RE n. 197.917/SP, 36 (trinta e seis) intervalos numéricos visando à
} 
houvesse desconformidade, O TSE determinaria O número de Vereadores a eleger.

Curiosamente, referida Resolução já previa a hipótese de uma reação do Congresso Nacional. o art. $3^{\circ}$ determinava que se houvesse emenda constitucional alterando os limites dispostos no art. 29, inciso IV, da Constituição, O TSE proveria a observância das novas regras.

Em oito de junho de 2004, porém, O TSE editaria nova Resolução ${ }^{94}$, em atendimento ao disposto o art. $2^{\circ}$ da Res. 21.702. Nela, o Anexo continha o número de Vereadores de todos os Municípios brasileiros, uma vez que as Câmaras Municipais desatenderam o determinado na Resolução do TSE anterior, desrespeitando, consequentemente, a decisão proferida pelo STF no RE $n$. $197.917 / \mathrm{SP}$.

Assim sendo, O PP (Partido Progressista) e o PDT (Partido Democrático Trabalhista) ajuizaram ações diretas de inconstitucionalidade visando à supressão da Res. 21.702/2004 do ordenamento jurídico brasileiro. A ADI n. 3.365/DF, ajuizada pelo PDT, foi apensada aos autos da ADI n. 3.345/DF, ajuizada pelo $\mathrm{PP}^{95}$.

Os argumentos dos dois partidos resumiamse a dois pontos: (i) a Resolução, na verdade, regulou o art. 29, IV, da Constituição, usurpando a competência do Legislativo, afrontando, assim, os arts. $2^{\circ}$ e 29, caput, da CRFB; (ii) o ato atacado não foi produto de interpretação

proporcionalidade na relação entre número de habitantes do Município e número de cadeiras na respectiva Câmara Municipal.

94 Resolução n. 21.803, de 8 de junho de 2004. Pet. n. 1.442/DF. Rel. Min. Carlos Velloso.

$95 \operatorname{ADI} n .3 .345 / \mathrm{DF}$, Rel. Min. Celso de Mello, j. 25.05.2005. 
da lei ou da Constituição, mas sim nova legislação eleitoral.

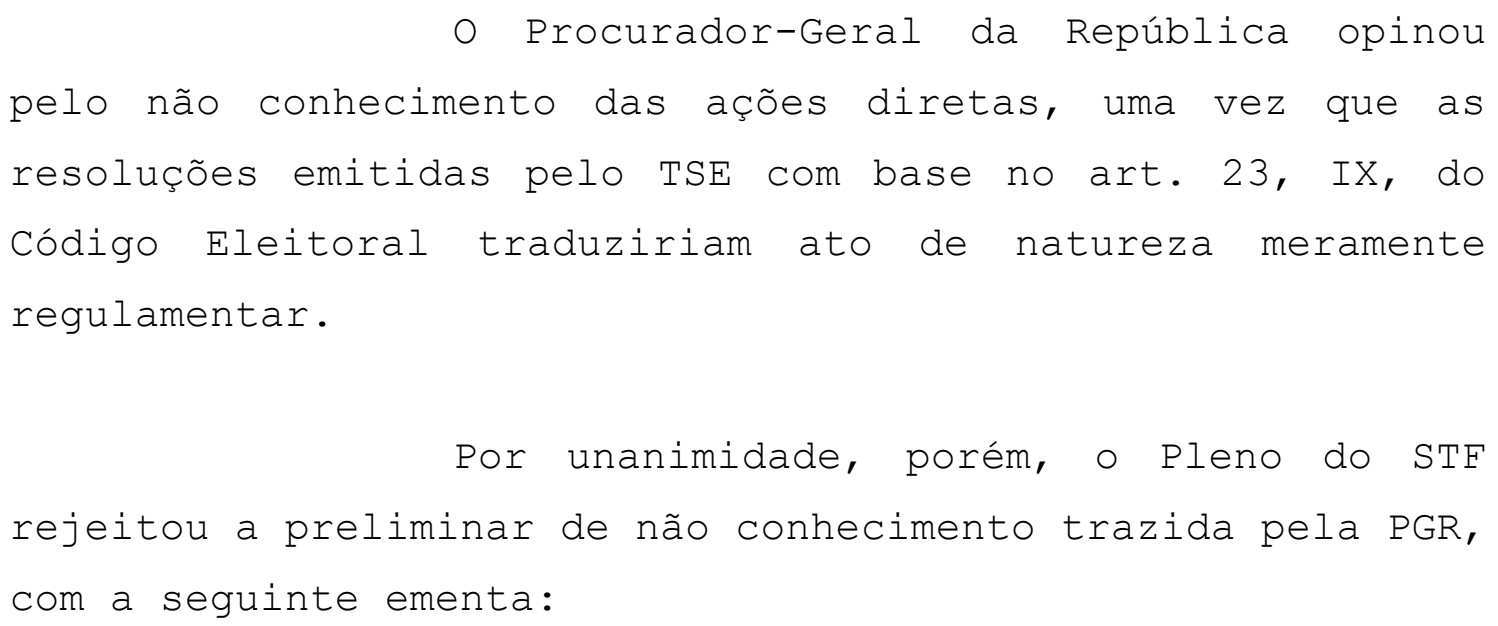

“RESOLUCÃO TSE N' 21.702/2004 - DEFINICÃO DE CRITÉRIOS A SEREM OBSERVADOS, PELAS CÂMARAS MUNICIPAIS, NA FIXACÃO DO RESPECTIVO NÚMERO DE VEREADORES ALEGACÃO DE QUE ESSE ATO REVESTIR-SE-IA DE NATUREZA MERAMENTE REGULAMENTAR RECONHECIMENTO DO CONTEÚDO NORMATIVO DA RESOLUÇÃO QUESTIONADA - PRELIMINAR DE NÃO-CONHECIMENTO REJEITADA.

- A jurisprudência do Supremo Tribunal Federal, em tema de fiscalização concentrada de constitucionalidade, firmou-se no sentido de que a instauração desse controle

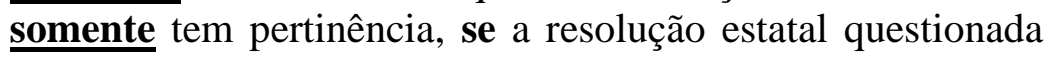
assumir a qualificação de ato normativo (RTJ 138/436 RTJ 176/655-656), cujas notas tipológicas derivam da conjugação de diversos elementos inerentes e essenciais à sua própria compreensão: (a) coeficiente de generalidade

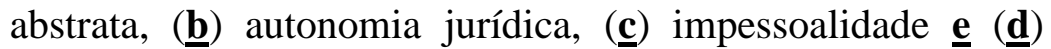
eficácia vinculante das prescrições dele constantes. Precedentes.

- Resolucão do Tribunal Superior Eleitoral, que, impugnada na presente ação direta, encerra, em seu conteúdo material, clara 'norma de decisão', impregnada de

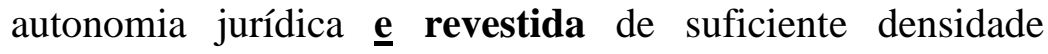
normativa: fatores que bastam para o reconhecimento de que o ato estatal em questão possui o necessário coeficiente de normatividade qualificada, apto a torna-lo suscetível de impugnação em sede de fiscalização abstrata". (grifos e destaques no original). 
Conhecida as ações, por maioria, foram julgadas improcedentes. O Min. Carlos Velloso, em seu voto, ressaltou que referida Resolução do TSE não poderia ser considerada inconstitucional, já que ela "simplesmente manda cumprir o decidido pelo Supremo Tribunal Federal ${ }^{96 "}$.

No mesmo sentido, o Min. Joaquim Barbosa afirmou que a Resolução impugnada "nada mais é que a pura expressão da força normativa da Constituição", já que "limitou-se a dar concretude à interpretação definitiva que - Supremo Tribunal Federal, guardião da Constituição, conferiu aos dispositivos constitucionais que estabelecem os referidos parâmetros ${ }^{97 \prime \prime}$.

O único voto divergente foi o do Min. Marco Aurélio. Seu voto tem como base o argumento de que o Tribunal Superior Eleitoral, por força do inciso IX do art. 23 do Código Eleitoral, não tem competência para regulamentar a Constituição.

Para sustentar sua posição, o Min. Marco Aurélio faz comparação com a competência consultiva do TSE (inciso XII do art. 23 do Código Eleitoral). Nesta, o TSE pode responder consultas, em matéria eleitoral, inclusive no que tange à Constituição da República. Na competência de baixar instruções, entretanto, o Min. Marco Aurélio crê que deve ser limitada à legislação infraconstitucional eleitoral.

96 ADI n. 3.345/DF, Rel. Min. Celso de Mello, j. 25.05.2005.

97 No mesmo sentido, o Min. Gilmar Mendes realçou que "o ato normativo ora impugnado apenas buscou conferir máxima efetividade aos critérios constitucionais aos quais os Municípios devem se ater para fixar o número de vereadores". 
Coerente com o que já havia afirmado no julgamento do RE n. 197.917/SP, O Min. Marco Aurélio encerra seu voto afirmando que a Resolução impugnada fere novamente a autonomia municipal, pois o TSE, na prática, substituiu os constituintes.

Diante desta decisão definitiva do STF sobre a constitucionalidade da atividade normativa do TSE que definiu, por meio de Resolução, o número de cadeiras em cada Câmara Municipal brasileira, o Congresso Nacional promulgou, em 23 de setembro de 2009, a Emenda Constitucional n. 58 .

O texto constitucional anterior, interpretado pelo STF no âmbito do RE n. 197.917/SP, previa o seguinte:

“Art. 29. O Município reger-se-á por lei orgânica, votada em dois turnos, com o interstício mínimo de dez dias, e aprovada por dois terços dos membros da Câmara Municipal, que a promulgará, atendidos os princípios estabelecidos nesta Constituição, na Constituição do respectivo Estado e os seguintes preceitos:

(...)

IV - número de Vereadores proporcional à população do Município, observados os seguintes limites:

a) mínimo de nove e máximo de vinte e um nos Municípios de até um milhão de habitantes;

b) mínimo de trinta e três e máximo de quarenta e um nos Municípios de mais de um milhão e menos de cinco milhões de habitantes;

c) mínimo de quarenta e dois e máximo de cinqüenta e cinco nos Municípios de mais de cinco milhões de habitantes;"

Ante a consequência direta da decisão do STF, qual seja, a edição, pelo TSE, de Resolução que fixou - número de cadeiras em cada Câmara Municipal do país, somada à confirmação da constitucionalidade da Resolução por meio de controle concentrado no Supremo, o Legislativo 
"IV - para a composição das Câmaras Municipais, será observado o limite máximo de:

a) 9 (nove) Vereadores, nos Municípios de até 15.000 (quinze mil) habitantes;

b) 11 (onze) Vereadores, nos Municípios de mais de 15.000 (quinze mil) habitantes e de até 30.000 (trinta mil) habitantes;

c) 13 (treze) Vereadores, nos Municípios com mais de 30.000 (trinta mil) habitantes e de até 50.000 (cinquenta mil) habitantes;

d) 15 (quinze) Vereadores, nos Municípios de mais de 50.000 (cinquenta mil) habitantes e de até 80.000 (oitenta mil) habitantes;

e) 17 (dezessete) Vereadores, nos Municípios de mais de 80.000 (oitenta mil) habitantes e de até 120.000 (cento e vinte mil) habitantes;

f) 19 (dezenove) Vereadores, nos Municípios de mais de 120.000 (cento e vinte mil) habitantes e de até 160.000 (cento sessenta mil) habitantes;

g) 21 (vinte e um) Vereadores, nos Municípios de mais de 160.000 (cento e sessenta mil) habitantes e de até 300.000 (trezentos mil) habitantes;

h) 23 (vinte e três) Vereadores, nos Municípios de mais de 300.000 (trezentos mil) habitantes e de até 450.000 (quatrocentos e cinquenta mil) habitantes;

i) 25 (vinte e cinco) Vereadores, nos Municípios de mais de 450.000 (quatrocentos e cinquenta mil) habitantes e de até 600.000 (seiscentos mil) habitantes;

j) 27 (vinte e sete) Vereadores, nos Municípios de mais de 600.000 (seiscentos mil) habitantes e de até 750.000 (setecentos cinquenta mil) habitantes;

k) 29 (vinte e nove) Vereadores, nos Municípios de mais de 750.000 (setecentos e cinquenta mil) habitantes e de até 900.000 (novecentos mil) habitantes;

1) 31 (trinta e um) Vereadores, nos Municípios de mais de 900.000 (novecentos mil) habitantes e de até 1.050.000 (um milhão e cinquenta mil) habitantes;

m) 33 (trinta e três) Vereadores, nos Municípios de mais de 1.050.000 (um milhão e cinquenta mil) habitantes e de até 1.200.000 (um milhão e duzentos mil) habitantes;

n) 35 (trinta e cinco) Vereadores, nos Municípios de mais de 1.200.000 (um milhão e duzentos mil) habitantes e de até 1.350 .000 (um milhão e trezentos e cinquenta mil) habitantes; 
o) 37 (trinta e sete) Vereadores, nos Municípios de 1.350.000 (um milhão e trezentos e cinquenta mil) habitantes e de até 1.500 .000 (um milhão e quinhentos mil) habitantes;

p) 39 (trinta e nove) Vereadores, nos Municípios de mais de 1.500.000 (um milhão e quinhentos mil) habitantes e de até 1.800.000 (um milhão e oitocentos mil) habitantes;

q) 41 (quarenta e um) Vereadores, nos Municípios de mais de 1.800.000 (um milhão e oitocentos mil) habitantes e de até 2.400.000 (dois milhões e quatrocentos mil) habitantes;

r) 43 (quarenta e três) Vereadores, nos Municípios de mais de 2.400.000 (dois milhões e quatrocentos mil) habitantes e de até 3.000.000 (três milhões) de habitantes;

s) 45 (quarenta e cinco) Vereadores, nos Municípios de mais de 3.000.000 (três milhões) de habitantes e de até 4.000.000 (quatro milhões) de habitantes;

t) 47 (quarenta e sete) Vereadores, nos Municípios de mais de 4.000.000 (quatro milhões) de habitantes e de até 5.000.000 (cinco milhões) de habitantes;

u) 49 (quarenta e nove) Vereadores, nos Municípios de mais de 5.000.000 (cinco milhões) de habitantes e de até 6.000.000 (seis milhões) de habitantes;

v) 51 (cinquenta e um) Vereadores, nos Municípios de mais de 6.000.000 (seis milhões) de habitantes e de até 7.000.000 (sete milhões) de habitantes;

w) 53 (cinquenta e três) Vereadores, nos Municípios de mais de 7.000.000 (sete milhões) de habitantes e de até 8.000.000 (oito milhões) de habitantes; e

x) 55 (cinquenta e cinco) Vereadores, nos Municípios de mais de 8.000.000 (oito milhões) de habitantes;"

no texto constitucional. O primeiro deles é a exclusão da proporcionalidade. Segundo, foram criados 24 (vinte e quatro) intervalos fixos na relação matemática entre número de cadeiras e população do Município.

\footnotetext{
Na prática, foram criadas sete mil novas vagas de vereadores em todo o território nacional. No texto da Emenda, porém, criou-se uma polêmica. O art. $3^{\circ}$ da EC n. 58/2009 previa que ela produziria efeitos a partir do processo eleitoral de 2008.
} 
Haveria confusão se este dispositivo realmente produzisse efeitos desde a promulgação, uma vez que poderia, numa interpretação benevolente, garantir vagas a candidatos derrotados nas eleições municipais de outubro de 2008, ou seja, garantir eficácia retroativa da norma ${ }^{98}$.

O TSE, entretanto, já havia sido provocado a se manifestar sobre o tema. No temor de que a proposta que resultou na EC n. 58/2009 pudesse ser aprovada já em 2007, foi protocolizada Consulta na Corte Eleitoral. Em sua resposta, o TSE opinou pelo fato de que possível Emenda só teria eficácia se houvesse sido aprovada antes do fim do prazo das correspondentes convenções partidárias ${ }^{99}$.

Diante da polêmica, a Procuradoria-Geral da República ajuizou uma ação direta de inconstitucionalidade visando à impugnação do dispositivo da Emenda que dava eficácia imediata a ela e, por consequência, dava liberdade às Câmaras Municipais a dar posse a diversos postulantes derrotados nas urnas em outubro de $2008^{100}$. No mesmo sentido, o Conselho Federal da Ordem dos Advogados do Brasil ajuizou outra ADI com objeto semelhante.

A Ministra Cármen Lúcia deferiu o pedido liminar feito pela PGR. Em 11 de novembro de 2009, por maioria, o Plenário do STF referendou a medida cautelar

\footnotetext{
98 Houve também quem interpretasse que a Resolução n. 21.074/2004 somente teve vigência nas eleições de 2004. Assim, no escrutínio de 2008, as Câmaras Municipais estariam livres para fixar o número de cadeiras de Vereador, atendido, obviamente, o limite constitucional das alíneas do inciso IV do art. 29 da Constituição. Neste sentido, José Nilo de Castro, Cristina Padovani Mayrink e Laura Spyer Prates: "Regulamentação - número de vereadores - Lei Orgânica Municipal possibilidade - até realização das convenções partidárias. In: Revista Brasileira de Direito Municipal, ano 10, n. 31, jan./mar. 2009.

99 Cta. n. 1.421/DF. Resolução n. 22.556, de 19 de junho de 2007, Rel. Min. José Delgado.

100 ADI n. 4.307/DF, Rel. Min. Cármen Lúcia, j. 11.04.2013.
} 
concedida, com eficácia ex tunc, nos termos do voto da Ministra Relatora.

No julgamento da ADI principal, invocando os princípios da segurança jurídica, da anterioridade eleitoral e do devido processo eleitoral, o Plenário do STF, por unanimidade, confirmou a cautelar deferida e julgou procedente a ação direta, determinando a inconstitucionalidade do inciso $I$ do art. $3^{\circ}$ da EC $n$. 58/2009. Na prática, referida emenda surtiu efeitos, portanto, somente nas eleições municipais de outubro de 2012 .

Esta decisão serve, para efeitos do presente trabalho, como real marco do conflito que surge entre Legislativo e Judiciário. Em sede de recurso extraordinário, o STF exerce o controle de constitucionalidade difuso e decreta a inconstitucionalidade de norma inserida na Lei Orgânica de um pequeno Município paulista no que tange à fixação do número de cadeiras de sua Câmara Municipal.

Para evitar maiores problemas na seara judicial, O STF demanda ao TSE uma decisão sobre como os Municípios deverão proceder diante da nova interpretação do inciso IV do art. 29 da Constituição, já que, na hipótese em comento, a competência do Senado Federal para suspender a execução, no todo ou em parte, de lei declarada inconstitucional por decisão definitiva do STF é inexistente, por se tratar de lei municipal.

Assim sendo, o TSE expede duas Resoluções tratando do tema. Insatisfeitos, dois partidos políticos ajuízam ações diretas de inconstitucionalidade com o mesmo 
objetivo: impugnar a atividade normativa da Corte Eleitoral no tema.

Afastada a inconstitucionalidade, 0 Congresso Nacional aprova emenda constitucional rechaçando, por completo, toda a interpretação construída no STF no que toca à proporcionalidade do número de cadeiras nas Câmaras Municipais em face da população do Município.

Peca o Legislativo, porém, em evidenciar sua inconformidade com as seguidas decisões proferidas pelo Judiciário no tema, quando aprova emenda com efeitos retroativos, com a nítida intenção de dar posse a mais de sete mil candidatos derrotados nas urnas de outubro de 2008 .

Esta postura, indubitavelmente, vai de encontro ao princípio da anterioridade eleitoral, previsto no art. 16 da Constituição. O Congresso quis mudar as regras do jogo eleitoral após o final do processo eleitoral, subvertendo a vontade popular expressada nas urnas por ocasião do escrutínio. O STF, novamente provocado em sede de controle de constitucionalidade concentrado, decidiu, cautelarmente, suspender a norma retroativa.

Em abril de 2013, definitivamente, confirmou a inconstitucionalidade da norma impugnada, fazendo prevalecer a segurança jurídica, ou seja: a EC n. 58/2009 vigeu normalmente nas eleições municipais de 2012.

Toda esta questão envolvendo a proporcionalidade do número de cadeiras nas Câmaras Municipais brasileiras é mais um sintoma do conflito 
generalizado entre os três Poderes (neste caso específico, entre o Legislativo e o Judiciário).

Ante a análise feita neste capítulo do fenômeno do ativismo judicial e ao trazer alguns exemplos concretos do acontecimento, passaremos a seguir para um estudo aprofundado da Justiça Eleitoral brasileira.

Nele, será realçado, por meio de exame doutrinário e jurisprudencial, como se dá os mecanismos legais e constitucionais da análise jurisdicional e consultiva na Justiça Eleitoral. Estes tópicos, ilustrados com diversos exemplos concretos em decisões do TSE e do STF, servirão para demonstrar como o fenômeno do ativismo judicial vem ganhando força no Brasil. 


\section{JUSTIÇA ELEITORAL BRASILEIRA}

- presente capítulo tem como principal objetivo a análise de diversos aspectos concernentes à Justiça Eleitoral no Brasil. Este estudo é necessário para que seja possível entender como se dá o fenômeno do ativismo judicial no Tribunal Superior Eleitoral.

Para tanto, primeiramente, será abordada a evolução constitucional da Justiça Eleitoral no Brasil. Serão trazidos à tona todos os dispositivos presentes nos textos constitucionais brasileiros, desde a constituição de 1934, a primeira que previu a Justiça Eleitoral, até a atual Constituição da República, de 5 de outubro de 1988.

Após a abordagem histórica, haverá a apreciação mais detalhada dos dispositivos constitucionais em relação aos órgãos jurisdicionais eleitorais, identificando suas funções, suas competências e, por fim, a grande importância deles para a normalidade e a legitimidade das eleições brasileiras nesse contexto histórico.

A análise do inciso IX do art. 23 do Código Eleitoral (Lei n. 4.737/1965) terá especial relevância. Este é o dispositivo chave no entendimento do fenômeno do ativismo judicial na Justiça Eleitoral. A previsão legal de o Tribunal Superior Eleitoral expedir instruções para a execução da legislação eleitoral é o verdadeiro nó górdio da polêmica.

Nele está a previsão de 0 TSE regulamentar o funcionamento das eleições brasileiras. No entanto, o TSE é também um órgão jurisdicional, fato este 
que pode levar à existência de conflitos entre o Judiciário e o Legislativo.

o último item deste capítulo trará à tona as principais decisões proferidas pelo Tribunal Superior Eleitoral e pelo Supremo Tribunal Federal no âmbito do direito político-eleitoral desde a promulgação da Constituição de 1988 .

A análise destas decisões terá como serventia a exemplificação do fenômeno do ativismo judicial no campo político-eleitoral. Para tanto, haverá a análise dos votos proferidos nos julgamentos, apontamentos jurisprudenciais e doutrinários e também das possíveis reações perpetradas pelo Poder Legislativo no contexto prático destas decisões.

\subsection{Evolução Constitucional}

A Constituição dos Estados Unidos do Brasil, promulgada em 16 de julho de 1934, foi a primeira a prever a Justiça Eleitoral em sede constitucional. Isso se deve, obviamente, ao fato dela ter sido criada no ordenamento jurídico brasileiro com $\circ$ advento do Código Eleitoral de 1932 .

A instituição da Justiça Eleitoral foi um dos "ideais inspiradores" da Revolução de 1930. Seu objetivo era o de "purificar o procedimento eleitoral, evitando as fraudes identificadas no período antecedente, contribuidoras para a deformação dos mecanismos de assunção 
do poder e provocadoras de verticalizadas instabilidades na estrutura organizacional política da Nação101".

Constitucionalmente, desde o texto de 1934 o Brasil tem a estrutura da Justiça Eleitoral bem definida, sem grandes mudanças. O art. 82, caput, previa que os órgãos seriam: (i) Tribunal Superior de Justiça Eleitoral, com sede no Rio de Janeiro, Capital da República; (ii) um Tribunal Regional sediado em cada Estado, no então Território do Acre e no Distrito Federal; (iii) juízes singulares em cada comarca brasileira. Suas atribuições seriam designadas por lei (no caso, pelo Código Eleitoral de 1932).

Quanto à presidência de cada Tribunal Eleitoral, a Constituição de 1934 previa que o presidente do TSJE seria O vice-presidente da Corte Suprema (atual Supremo Tribunal Federal). Nos tribunais regionais, o presidente seria o vice-presidente da respectiva Corte de Apelação (atual Tribunal de Justiça dos Estados) •

No que toca à composição, havia muitas diferenças. $02^{\circ}$ do art. 82 dispunha que: (i) um terço dos juízes seria composto por Ministros da Corte Suprema, por sorteio; (ii) outro terço seria ocupado por Desembargadores da Corte de Apelação do Distrito Federal, também por sorteio; (iii) por fim, o terço restante seria ocupado por pessoas nomeadas pelo Presidente da República, em uma lista que conteria seis cidadãos de notável saber jurídico e reputação ilibada. Esta lista seria formada por pessoas

101 DELGADO, José Augusto. "A contribuição da Justiça Eleitoral para o aperfeiçoamento da democracia". In: Revista dos Tribunais, n. 718, ago./1995, p. 318. No mesmo sentido, Gilmar Mendes aponta que "a Justiça Eleitoral é, talvez, o filho dileto da Revolução de 1930". ("A atividade normativa da Justiça Eleitoral no Brasil". In: CoSTA, Marcio A. Mendes. Direito e democracia: debates sobre reforma política e eleições. Rio de Janeiro: EJE/TRE-RJ, 2008, p. 51). 
indicadas pela corte suprema. Os tribunais regionais compor-se-iam de modo análogo.

A rotatividade dos membros dos Tribunais Eleitorais já estava prevista no texto de 1934. O mandato previsto era de dois anos, sendo possível a renovação por somente mais um biênio (art. 82, \$ $5^{\circ}$ ).

A competência da Justiça Eleitoral para a organização e processo das eleições estava também prevista constitucionalmente, sendo ela privativa (art. 83, caput). Além do processo das eleições federais, estaduais e municipais, cabia à Justiça Eleitoral, entre outras diversas competências organizacionais, processuais e recursais, (i) processar as eleições dos representantes das profissões; (ii) organizar a divisão eleitoral da União, dos Estados, do Distrito Federal e dos Territórios; (iii) adotar ou propor providências para que as eleições se realizem no tempo e na forma determinados em lei; (iv) fixar a data das eleições na hipótese de a data não ter sido fixada pela Constituição ou nas Constituições dos Estados.

Ao proceder à comparação com a atual Constituição, pode-se constatar que a estrutura realmente é parecida, havendo, atualmente, a previsão de um tribunal superior (TSE), de tribunais regionais e de juízes eleitorais (art. 118, incisos I a III, CRFB).

A composição do TSE é absolutamente diferente daquela registrada em 1934. Primeiramente, há a previsão de um número mínimo (sete membros). No entanto, os incisos do art. 119 deixam claro que o número é de sete membros, não havendo como, a não ser por meio de uma emenda 
constitucional, aumentar o número de julgadores no órgão máximo da Justiça Eleitoral. Dentre os sete membros, três juízes advêm do Supremo Tribunal Federal (eleitos, pelo voto secreto, entre seus pares). Dois juízes do TSE serão também eleitos, secretamente, pelo superior Tribunal de Justiça, dentre seus membros. Por fim, os outros dois juízes do TSE são nomeados, pelo Presidente da República, dentre seis advogados (e não cidadãos) indicados pelo STF. O requisito constitucional de notável saber jurídico continua previsto. O outro requisito atualmente exigido é a idoneidade moral, bastante semelhante, para não dizer idêntico, à reputação ilibada.

Atualmente, cabe aos membros do TSE escolherem o presidente, o vice-presidente e o corregedor eleitoral. A Constituição exige, entretanto, que os dois primeiros cargos sejam ocupados por Ministro do STF e que a corregedoria seja chefiada por Ministro do STJ (art. 119, parágrafo único, $\mathrm{CRFB}$ ) .

Perdeu status constitucional a previsão contida no Texto de 1934 para a Justiça Eleitoral organizar a processar as eleições. A organização da divisão eleitoral das unidades federativas é, atualmente, competência constitucional do Poder Legislativo, por meio de legislação complementar, em respeito ao ditame constitucional ${ }^{102}$. As datas para a ocorrência das eleições estão todas fixadas na própria Constituição da República em todos os âmbitos

102 "Art. 45. A Câmara dos Deputados compõe-se de representantes do povo, eleitos, pelo sistema proporcional, em cada Estado, em cada Território e no Distrito Federal.

$\$ 1^{\circ}$ - O número total de Deputados, bem como a representação por Estado e pelo Distrito Federal, será estabelecido por lei complementar, proporcionalmente à população, procedendo-se aos ajustes necessários, no ano anterior às eleições, para que nenhuma daquelas unidades da Federação tenha menos de oito ou mais de setenta Deputados". 
federativos. Por fim, hoje a previsão normativa para que a Justiça Eleitoral tenha o poder de adotar ou propor providências para a realização das eleições é legal (Código Eleitoral), e não mais constitucional.

A Constituição de 10 de novembro de 1937, advinda da decretação do regime ditatorial do Estado Novo pelo presidente Getúlio Vargas, não faz qualquer menção à Justiça Eleitoral. No capítulo que trata do Poder Judiciário, o art. 90 prevê como órgãos deste poder o Supremo Tribunal Federal, os Juízes e Tribunais dos Estados, do Distrito Federal e dos Territórios e os Juízes e Tribunais militares.

Já a Constituição de 18 de setembro de 1946, promulgada após a queda de Getúlio Vargas, novamente prevê a existência da Justiça Eleitoral. Os órgãos previstos são os mesmos dispostos no Texto de 1988.

A composição, novamente, tem diferença em relação à Constituição atual. Ao invés de três ministros do STF, havia dois ministros. Como o STJ só foi criado pela Constituição de 1988, a Constituição de 1946 previa que dois juízes do TSE teriam como origem o Tribunal Federal de Recursos (extinto em 1988).

Por fim, além dos dois advogados (nomeados e indicados da mesma forma na atual Constituição), o Texto de 1946 também previa que um dos juízes do TSE adviria do Tribunal de Justiça do Distrito Federal (art. 110, Constituição de 1946). O TSE tinha a competência para escolher seu presidente e o respectivo vice-presidente, mas ambos deveriam ter como origem o STF. 
O art. 119 da Constituição de 1946 previa a competência da Justiça Eleitoral brasileira, que deveria ser regulada por lei. Entre diversas competências, incluise a divisão eleitoral do País (assim como em 1934), o processo eleitoral e a fixação da data das eleições, quando não houver determinação constitucional ou legal. A previsão contida no Texto de 1934 quanto à competência da Justiça Eleitoral para a adoção e proposição de providência para a realização das eleições deixou de ter status constitucional.

Esta Constituição, bem como suas sucessoras, manteve a existência da Justiça Eleitoral por um simples motivo: afastar membros da política brasileira da gestão da infraestrutura eleitoral nacional ${ }^{103}$.

A Constituição outorgada em 1967 não procedeu a nenhuma modificação no que tange aos órgãos da Justiça Eleitoral, bem como quanto à composição do Tribunal Superior Eleitoral, assim como no que toca à presidência e vice-presidência da corte superior eleitoral.

O art. 130 da referida Carta determina que cabe à lei estabelecer a competência dos órgãos jurisdicionais eleitorais. Entre outras atribuições, a divisão eleitoral do país, a fixação das datas das eleições (na ausência de previsão constitucional ou legal), bem como - processamento das eleições continuaram a ter status constitucional (incisos II, IV e V do art. 130).

\footnotetext{
103 Concorda com este posicionamento Gilberto Guerzoni Filho, ao ventilar que "a implantação de um sistema eleitoral democrático se caracterizou não pelo amadurecimento do sistema político-partidário, mas pela desconfiança sobre este". ("A Justiça eleitoral no Brasil: a desconfiança como elemento fundamental de nosso sistema eleitoral". In: Revista de Informação Legislativa, ano 41, n. 161, jan./mar. 2004, p. 43).
} 
Esta Carta, porém, vigeu por pouco tempo. o endurecimento do regime militar iniciado em 1964 fez com que fosse outorgada uma emenda constitucional que, na prática, se tratava de uma nova Constituição. No que tange à Justiça Eleitoral, a Emenda Constitucional n. 1, de 17 de outubro de 1969, trouxe substanciosas modificações.

A primeira delas ocorreu na composição do TSE. O art. 131, inciso I, alínea "a", previa que três ministros do STF passariam a ser membros da corte eleitoral. A vaga destinada a um desembargador do Tribunal de Justiça do Distrito Federal deixou de existir.

A EC N. 1/1969, no art. 140, determinou que os territórios federais do Amapá, Roraima, Rondônia e Fernando de Noronha ficariam sob a jurisdição eleitoral, respectivamente, dos Tribunais Regionais do Pará, Amazonas, Acre e Pernambuco.

Por fim, vale rememorar a importância da Justiça Eleitoral no contexto político brasileiro. o Judiciário especializado em questões eleitorais teve tamanho sucesso que nem mesmo na Ditadura Militar houve qualquer tentativa de extinção das Cortes Eleitorais.

Maria Tereza Sadek, nesse sentido, reitera o argumento, ao ressaltar que:

“(...) a Justiça Eleitoral foi mantida mesmo durante o regime militar, de 1964 a 1985. Houve, nesse período, uma série de deliberadas restrições na competitividade, a começar pela implantação do bipartidarismo compulsório. Mas a Justiça Eleitoral continuou a crescer institucionalmente, e foi sua atuação como um organismo independente que garantiu a proclamação de resultados contrários aos esperados pelo regime. $\mathrm{O}$ próprio processo de 'abertura' iniciado nos anos 70, ancorado como foi na disputa eleitoral, teria sido impensável se o Brasil não dispusesse, a essa 
altura de procedimentos razoavelmente confiáveis de administração e controle do processo eleitoral ${ }^{104,}$.

A adoção do sistema jurisdicional também é saudada por Rodolfo Viana Pereira. O autor sustenta que a jurisdicionalização do contencioso eleitoral além de ser tendência mundial, por sua intrínseca "superioridade", também vem sendo tratada como uma das "características essenciais do sistema político democrático ${ }^{105 "}$.

\subsection{Constituição de 1988: órgãos e competência} jurisdicional

A Constituição de 1988 não promoveu nenhuma mudança, em comparação à Emenda Constitucional n. 1/1969 no que toca aos órgãos da Justiça Eleitoral. São eles, conforme art. 118: (i) Tribunal Superior Eleitoral; (ii) Tribunais Regionais Eleitorais; (iii) Juízes Eleitorais; (iv) Juntas Eleitorais.

Já a composição do TSE sofreu duas alterações. O caput do art. 119 prevê que o TSE terá, no mínimo, sete membros. No entanto, os incisos do mesmo artigo determinam que os membros sejam sete: três Ministros do STF, dois Ministros do STJ e dois advogados.

Os ministros do STF deverão ser eleitos por seus pares, secretamente, assim como os ministros do STJ. A Emenda n. $1 / 1969$ previa que dois membros do TSE adviriam do Tribunal Federal de Recursos, corte esta extinta pela Constituição de 1988. O TSE tem a competência

\footnotetext{
104 SADEK, Maria Tereza. A Justiça Eleitoral e a consolidação da democracia no Brasil. São Paulo: Fundação Konrad Adenauer, 1995, p. 2. 105 PEREIRA, Rodolfo Viana. "Contencioso eleitoral: polissemia conceitual, sistemas comparados e posição brasileira". In: Anais do XX Congresso Nacional do CONPEDI realizado em Vitória/ES. Florianópolis: Fundação Boiteux, 2012, p. 4216.
} 
para eleger seu presidente, vice-presidente e corregedor eleitoral.

\author{
A Constituição, porém, determina que o \\ presidente e seu substituto devem ser eleitos dentre \\ ministros do STF, bem como o corregedor deve ser um dos \\ dois ministros do STJ.
}

Por fim, as outras duas vagas serão preenchidas por advogados de notável saber jurídico e idoneidade moral ${ }^{106}$. Estes dois juízes serão nomeados pelo Presidente da República dentre uma lista tríplice ${ }^{107}$ indicada pelo Supremo Tribunal Federal ${ }^{108}$.

A Constituição de 1988 previu também a composição dos vinte e sete Tribunais Regionais Eleitorais,

\footnotetext{
${ }^{106}$ Antonio Carlos da Ponte rememora que a Justiça Eleitoral constituise em exceção no que toca ao limite de idade de seus magistrados. Enquanto em todos os outros órgãos do Judiciário não há qualquer magistrado com mais de setenta anos de idade, devido à disposição constitucional de aposentadoria compulsória, na Justiça Eleitoral "os advogados que ocupam as vagas destinadas aos juristas podem ser recrutados dentre profissionais com mais de setenta anos". Crimes eleitorais. São Paulo: Saraiva, 2008, p. 3.

107 O inciso II do art. 119 da CRFB prevê que "dois juízes dentre seis advogados de notável saber jurídico e idoneidade moral, indicados pelo Supremo Tribunal Federal" serão nomeados pelo Presidente da República. Antonio Carlos da Ponte defende que para cada nomeação deve ser feita uma lista sêxtupla. Entendemos que o STF, em cada nomeação, deve proceder à escolha de três nomes para a composição de lista a ser enviada ao Presidente da República.

108 Suzana de Camargo Gomes relembra que "nas listas embasadoras das escolhas dos membros-juristas não podem constar nomes de magistrados aposentados, nem componentes do Ministério Público em atividade. Esses impedimentos legais são determinados pela preocupação de se evitarem distorções nas Cortes Eleitorais, que devem contar com dois membros efetivamente oriundos da advocacia, pois, neste particular, impera o princípio da diversidade de origem na composição dos órgãos colegiados.". A Justiça Eleitoral e sua competência. São Paulo: Editora Revista dos Tribunais, 1998, p. 58. No mesmo sentido, Antonio Carlos da Ponte atesta que "não se aplica aos Tribunais Eleitorais a regra do quinto constitucional, posto que não foi conferido ao Ministério público o direito de indicar membros a compor" o TSE e o TRE. (Crimes eleitorais. São Paulo: Saraiva, 2008, p. 4).
} 
pois cada unidade federativa deverá ter um ${ }^{109}$. Dois desembargadores do Tribunal de Justiça serão eleitos pelo voto secreto dentre seus pares. O TJ escolherá também secretamente dois juízes de direito.

A quinta vaga é para membro da Justiça Federal. A Constituição prevê (art. 120, \$ $1^{\circ}$, II) que esta vaga será preenchida por um desembargador federal do Tribunal Regional Federal com sede na capital do Estado ou no Distrito Federal. Não havendo tribunal federal sediado na capital, o respectivo TRF escolherá um juiz federal para ocupar a vaga.

As duas vagas de advogado, de notável saber jurídico e idoneidade moral ${ }^{110}$, são também de nomeação pelo Presidente da República. A lista tríplice, porém, é de competência do Tribunal de Justiça. O presidente e seu vice-presidente devem ser escolhidos pelo próprio TRE, mas a origem deles deve ser o Tribunal de Justiça.

Os juízes eleitorais são magistrados de $1^{\circ}$ grau da Justiça Estadual. Eles são designados pelo respectivo TRE para a presidência de zonas eleitorais que, em regra, correspondem às comarcas judiciais.

Já as Juntas Eleitorais são órgãos colegiados, de $1^{\circ}$ grau, previstas desde a Constituição de 1934. Seus membros, sendo um necessariamente juiz de direito, detêm as garantias constitucionalmente previstas aos magistrados.

109 O número de membros previsto na Constituição para cada TRE é de sete juízes. O Código Eleitoral prevê a possibilidade de o número ser elevado a nove membros, mediante proposta do TSE (art. 13).

110 Roberto Rosas sustenta que a Constituição, ao exigir estes dois requisitos do advogado, quer que eles "estejam acima da média ou do comum". ("O sucesso da Justiça Eleitoral", In: Revista do Instituto dos Advogados de São Paulo, n. 2, p. 140). 
Sua função precípua é a apuração contagem e totalização - dos votos em cada zona eleitoral. Joel Cândido defende que com a modernização eletrônica da apuração da votação, "as Juntas não têm mais sentido", devendo ser "imediatamente extintas"11".

O art. 121, caput, assevera que cabe à lei complementar a disposição sobre a organização e competência dos tribunais, dos juízes de direito e das juntas eleitorais.

A Constituição, mais uma vez, prevê a duração de dois anos, sendo permitida uma única recondução consecutiva, para o mandato do magistrado eleitoral nos tribunais. Na mesma ocasião de escolha dos juízes, devem ser eleitos seus respectivos substitutos.

A irrecorribilidade das decisões do TSE também está prevista no Texto de 1988. Há, porém, exceções a esta regra, quais sejam: (i) decisão que contrarie os mandamentos constitucionais; (ii) decisão denegatória de mandado de segurança ou habeas corpus.

A impossibilidade de recurso judicial contra decisão dos TREs também é regra constitucional. A Constituição prevê quatro exceções: (i) decisão contra disposição constitucional ou legal expressa; (ii) decisão que contenha interpretação legal divergente em relação a outros tribunais eleitorais; (iii) decisão que verse sobre inelegibilidade ou expedição de diploma nas eleições federais ou estaduais; (iv) julgamento que anule diploma ou

111 CÂNDIDO, Joel José. Direito eleitoral brasileiro. Bauru: Edipro, $13^{\text {a }}$ ed. rev., atual. e ampl., 2008, p. 55. 
decrete perda de mandato eletivo federal ou estadual; (v) decisão denegatória de mandado de segurança, habeas corpus, habeas data ou mandado de injunção.

Finalmente, deve ser ressaltada a competência do STF e do STJ no âmbito eleitoral. Apesar de ambas as Cortes Superiores não pertencerem à "estrutura hierárquica da Justiça Eleitoral", elas detêm a possibilidade constitucional de conhecer de matérias pertinentes à seara eleitoral.

O STF, por exemplo, tem a competência originária de resolver conflitos de competência entre o TSE e qualquer outro tribunal superior. Ademais, no âmbito penal, o Supremo detém competência, de natureza funcional, originária para julgar ações penais de detentores de certos cargos do Estado ${ }^{112}$. No mais, O STF também detém a competência recursal (inciso III do art. 102 da CRFB) em matéria eleitoral.

112 "Art. 102. Compete ao Supremo Tribunal Federal, precipuamente, a guarda da Constituição, cabendo-lhe:

I - processar e julgar, originariamente:

$(\ldots)$

b) nas infrações penais comuns, o Presidente da República, o VicePresidente, os membros do Congresso Nacional, seus próprios Ministros e o Procurador-Geral da República;

c) nas infrações penais comuns e nos crimes de responsabilidade, os Ministros de Estado e os Comandantes da Marinha, do Exército e da Aeronáutica, ressalvado o disposto no art. 52, I, os membros dos Tribunais Superiores, os do Tribunal de Contas da União e os chefes de missão diplomática de caráter permanente;

d) o "habeas-corpus", sendo paciente qualquer das pessoas referidas nas alíneas anteriores; 0 mandado de segurança e o "habeas-data" contra atos do Presidente da República, das Mesas da Câmara dos Deputados e do Senado Federal, do Tribunal de Contas da União, do Procurador-Geral da República e do próprio Supremo Tribunal Federal; $(\ldots)$

i) o habeas corpus, quando o coator for Tribunal Superior ou quando o coator ou o paciente for autoridade ou funcionário cujos atos estejam sujeitos diretamente à jurisdição do Supremo Tribunal Federal, ou se trate de crime sujeito à mesma jurisdição em uma única instância; $(\ldots)$

o) os conflitos de competência entre o Superior Tribunal de Justiça e quaisquer tribunais, entre Tribunais Superiores, ou entre estes e qualquer outro tribunal". 
Já O STJ tem a seguinte competência na seara eleitoral: (i) originária na seara penal eleitoral, em razão de competência funcional; (ii) para resolver conflitos de competência entre o TSE e tribunais de segundo grau não pertencentes à Justiça Eleitoral, mesmo quando o objeto do conflito for de matéria eleitoral ${ }^{113}$.

Antes de passar ao exame das competências da Justiça Eleitoral no regime democrático de 1988, deve-se fazer uma rápida análise de suas virtudes, mas também dos pontos para eventuais correções, uma vez que há diversas propostas para o melhor aprimoramento de suas tarefas constitucionais.

Primeiramente, deve se ressaltar que apesar do vigoroso sucesso no que concerne ao principal objetivo quando da sua criação, qual seja, garantir credibilidade aos resultados eleitorais, também é necessário admitir que há muito a avançar. Sua estrutura, por exemplo, principalmente no que tange à magistratura e ao Ministério Público Eleitoral, é sempre transitória.

A aplicação por todas as constituições que previram a organização e o funcionamento da Justiça Eleitoral dos princípios (i) da diversidade de origem na

\footnotetext{
113 "Art. 105. Compete ao Superior Tribunal de Justiça:

I - processar e julgar, originariamente:

a) nos crimes comuns, os Governadores dos Estados e do Distrito Federal, e, nestes e nos de responsabilidade, os desembargadores dos Tribunais de Justiça dos Estados e do Distrito Federal, os membros dos Tribunais de Contas dos Estados e do Distrito Federal, os dos Tribunais Regionais Federais, dos Tribunais Regionais Eleitorais e do Trabalho, os membros dos Conselhos ou Tribunais de Contas dos Municípios e os do Ministério Público da União que oficiem perante tribunais; $(\ldots)$

d) os conflitos de competência entre quaisquer tribunais, ressalvado o disposto no art. 102, I, "০", bem como entre tribunal e juízes a ele não vinculados e entre juízes vinculados a tribunais diversos".
} 
composição dos órgãos colegiado, bem como o (ii) da periodicidade da investidura dos Juízes traz duas graves consequências.

A principal decorrência cinge-se ao fato de que a rotatividade na magistratura eleitoral traz enorme instabilidade na jurisprudência, prejudicando, de certo, o princípio da segurança jurídica ${ }^{114}$. O item 3.4 .2 deste capítulo, que versa sobre as decisões do TSE sobre o alcance da certidão de quitação eleitoral é exemplo lapidar desse fenômeno.

Já a segunda implicação é a seguinte: apesar de seu funcionamento ser permanente, a Justiça Eleitoral não conta com magistratura própria.

A escolha do Brasil, desde a Constituição de 1934, por adotar o sistema jurisdicional do controle do processo eleitoral denotou que o Legislativo e o Executivo não teriam mais a legitimidade para a fiscalização e administração das eleições. A intenção, como já estudado anteriormente, era garantir a lisura das disputas eleitorais.

Assim sendo, a previsão de que a Justiça Eleitoral não contaria com um corpo de magistrados próprios, bem como seus Tribunais teriam composição heterogênea e mandatos definidos tem o claro objetivo de

\footnotetext{
114 Maria Tereza Sadek traz outra perspectiva diante da volubilidade jurisprudencial apresentada pela Justiça Eleitoral. Para a autora, a "instabilidade da legislação também tem estimulado a pluralidade de decisões. Nos últimos decênios, não houve praticamente duas eleições regidas por um mesmo texto legal. Mudanças constantes dificultam o desenvolvimento de entendimentos uniformes e criação de padrões de comportamento". A Justiça Eleitoral e a consolidação da democracia no Brasil. São Paulo: Fundação Konrad Adenauer, 1995, p. 63.
} 
garantir a neutralidade na condução, na administração e nos julgamentos das lides apresentadas.

Para estudar as competências infraconstitucionais da Justiça Eleitoral, é necessário situar suas principais características. Até 1932, o Brasil adotava o chamado de "sistema de verificação dos poderes". Assim, cabia ao Legislativo o controle das eleições, sem qualquer ingerência dos poderes Executivo e Judiciário. Surgiu em vários países, em decorrência da má influência exercida pelo monopólio do Legislativo na administração das questões eleitorais o denominado sistema eclético. Este se caracteriza por sua composição heterogênea, ou seja, a realização e a fiscalização das eleições são "delegadas a membros do Legislativo em conjunto com outros elementos oriundos de poderes diversos ${ }^{115 \prime \prime}$.

Com a adoção do sistema jurisdicional de controle das eleições, em 1932 e vigente até hoje, a Justiça Eleitoral detém competências típicas de um órgão jurisdicional, como também alçadas atípicas.

Sua competência jurisdicional infraconstitucional está detalhada no Código Eleitoral de 1965, no art. 22, no que tange ao TSE.

Dividem-se a competência recursal e a originária. Nesta, pode-se destacar: (i) o registro e a cassação de registro de partidos políticos e das candidaturas ao Palácio do Planalto; (ii) conflitos de competência entre tribunais regionais e juízes eleitorais de Estados diferentes; (iii) impugnação à apuração do

115 GOMES, Suzana de Carvalho. "A competência da Justiça Eleitoral". In: Revista Brasileira de Direito Constitucional, n. 3, jan./jun. 2004, p. 716 . 
resultado geral, proclamação dos eleitos e expedição de diploma na eleição nacional (Presidência da República) .

Os parágrafos do referido dispositivo dão a todos os magistrados eleitorais algumas prerrogativas dos magistrados provenientes de outras especializações do Poder Judiciário brasileiro, com destaque à inamovibilidade (art. 121, \$ $1^{\circ}$, in fine).

$$
\text { Importante ressaltar que o parágrafo }
$$

único do art. 19 prevê que as decisões do TSE que deliberem sobre (i) a interpretação do Código Eleitoral em face da Constituição; (ii) cassação de registro de partidos políticos; (iii) recursos que importem anulação geral de eleições ou perda de diplomas; somente poderão ser tomadas com a presença de todos os membros.

Paulo Henrique Santos Lucon e José Marcelo Menezes Vigliar ensinam que "as decisões que importam em comparação com a Constituição Federal são, por exemplo: as inelegibilidades reflexas (art. 14, $\$ 7^{\circ}$ ); perda e suspensão dos direitos políticos (arts. 15, 55, IV, VI); condições de elegibilidade constitucionais (art. 14, \$ $\left.3^{\circ}\right)^{116 \prime \prime}$.

Interessante notar que o tradicional princípio da inércia sofre temperamentos no âmbito eleitoral. A Justiça Eleitoral, por também deter o poder de polícia ${ }^{117}$, pode e deve atuar de ofício "sempre que o

\footnotetext{
116 LUCON, Paulo Henrique dos Santos; VIGLIAR, José Marcelo Menezes. Código eleitoral interpretado: normas eleitorais complementares. São Paulo: Atlas, $2^{a}$ ed., 2011, p. 29.

117 Esta competência administrativa está destacada no Código Eleitoral no que diz respeito à propaganda eleitoral irregular, conforme previsão do art. 249 do diploma.
} 
interesse público o determinar, visando, assim, garantir a legalidade e a legitimidade dos pleitos ${ }^{118 "}$.

A Justiça Eleitoral também é dotada de competência de caráter administrativo, sendo elas arroladas no art. 23 do Código Eleitoral. Primeiramente, veem-se as competências de autogoverno (incisos I a III, X). Os incisos IV a VI tratam da competência do TSE em relação aos TREs, como aprovar afastamento de juízes, propor a criação de TRE em Território Federal ou o aumento do número de membros em um TRE.

O envio da lista tríplice, prevista constitucionalmente, organizada pelo Tribunal de Justiça com a indicação de advogados para a composição dos tribunais regionais ao Presidente da República é função do TSE (art. 23, XI, C/C art. 25, $\$ 1^{\circ}$, ambos do Código Eleitoral).

O inciso VII do art. 23 tornou-se letra morta. A competência do TSE para fixar a data das eleições presidenciais, para a Câmara dos Deputados e para o Senado Federal foi suprimida pela Constituição de 1988, que já dispõe taxativamente sobre o assunto.

A divisão dos Estados em zonas eleitorais ou mesmo a criação de novas zonas cabe também ao TSE. Importante não haver confusão com os dispositivos constitucionais de 1934, 1946, 1967 e da Emenda Constitucional n. 1/1969 que tratava da divisão eleitoral como competência da Justiça Eleitoral. Esta dispunha sobre - número de deputados federais por unidade federativa; já o

\footnotetext{
118 GOMES, Suzana de Camargo. A Justiça Eleitoral e sua competência. São Paulo: Editora Revista dos Tribunais, 1998, p. 80.
} 
inciso VIII do art. 23 trata somente da divisão territorial das zonas eleitorais.

o processamento das eleições também é de competência do Tribunal Superior Eleitoral. Além disso, a contagem de votos quando solicitado por TRE (inciso XIII), a requisição de força federal necessária para o cumprimento da lei, visando a garantir o cumprimento da legislação, de suas próprias decisões, de julgamentos proferidos pelos TREs, a votação e a apuração (inciso XIV) é seara da corte Superior.

Suzana de Camargo Gomes explana, de forma sucinta, a importância do trabalho da Justiça Eleitoral no campo administrativo eleitoral, conforme trecho a seguir:

"E neste âmbito assume também a Justiça Eleitoral atribuições de ordem eminentemente administrativas e também que consubstanciam atos de jurisdição voluntária, ditadas pela finalidade de propiciar o eficaz funcionamento do serviço eleitoral, dotando-a, assim, de poderes que autorizam a adoção das medidas preventivas necessárias à segurança da soberania da vontade popular, e que impedem, destarte, qualquer desvirtuamento da manifestação do povo nas urnas ${ }^{119,}$.

Por fim, cabe enfatizar que O TSE tem duas funções de suma importância para o presente trabalho: a função regulamentar (inciso IX - "expedir as instruções que julgar convenientes à execução deste código) e a peculiar competência de responder a consultas, em matéria eleitoral, formuladas, em tese (ou seja, sem qualquer relação a um caso concreto), por autoridade com jurisdição, federal ou órgão nacional de partido político (inciso XII) . Estas duas últimas funções serão examinadas no próximo item deste trabalho.

\footnotetext{
${ }^{119}$ GOMES, Suzana de Camargo. A Justiça Eleitoral e sua competência. São
} Paulo: Editora Revista dos Tribunais, 1998, p. 80-81. 
3.3. Competências Consultiva e Regulamentar: o art. 23, incisos IX e XII, do Código Eleitoral

Analisado o histórico constitucional da Justiça Eleitoral, sua estrutura hierárquica e também suas competências jurisdicionais e administrativas, passaremos ao exame de sua competência atípica, verdadeiramente sui generis: (i) a normativa/regulamentar e (ii) a consultiva.

No contexto deste trabalho, este tema será abordado duas vezes. Neste item será feita uma breve reflexão sobre o assunto, uma vez que o objetivo principal deste capítulo é trazer o contexto histórico e constitucional da Justiça Eleitoral brasileira e, no final, trazer à tona o exame detalhado de decisões exaradas pelo TSE em três assuntos diferentes sob o ângulo do fenômeno do ativismo judicial.

Como as duas competências da Justiça Eleitoral tratadas neste momento são, além de peculiares, àquelas que possibilitara legalmente 0 aparecimento do fenômeno do ativismo judicial no exercício da competência jurisdicional eleitoral, elas serão abordadas aqui de maneira introdutória.

Já no item 4.5, ou seja, na análise dos argumentos apresentados pelo Supremo Tribunal Federal para não conhecer a ação direta de inconstitucionalidade que visava à extirpação da interpretação do TSE sobre a verticalização das coligações partidárias do ordenamento jurídico, uma análise pormenorizada das competências regulamentar e consultiva da Justiça Eleitoral será fundamental para o enrijecimento do que está sendo 
defendido neste trabalho: a Justiça Eleitoral, com o aval do STF, tem exacerbado seus poderes ao utilizar de sua competência normativa/regulamentar e consultiva, fato este que demonstra a ocorrência do fenômeno do ativismo judicial na seara eleitoral. Diante desse breve aparte, voltemos à análise resumida das competências atípicas da Justiça Eleitoral.

Nesse contexto, as palavras de Torquato Jardim ajudam a entender a natureza das competências da Justiça Eleitoral. Segundo o autor,

"embora montada em modelo tipicamente judiciário estrutura, forma, pessoal, vestes talares e jargão judiciário - sua [Justiça Eleitoral] tarefa é essencialmente administrativa, e só eventualmente jurisdicional. Processo eleitoral é um processo administrativo, e o que o singulariza é a unicidade do órgão administrativo executor e do órgão judiciário incumbido do seu controle judicial ${ }^{120 "}$.

$\mathrm{Na}$ seara administrativa, aparecem como peculiaridades as hipóteses legais previstas nos incisos IX e XII do art. 23 do Código Eleitoral ${ }^{121}$ : (i) regulamentar o processo eleitoral por meio de instruções; (ii) responder a consultas.

A Constituição de 1988, ao contrário do disposto sobre a atividade normativa da Justiça do Trabalho (art. 114, $\left.\$ 2^{\circ}, \mathrm{CRFB}\right)$, é silente sobre a atividade normativa/regulamentar da Justiça Eleitoral. Mesmo sem previsão constitucional, entendeu-se que as duas

\footnotetext{
120 JARDIM, Torquato. Direito eleitoral positivo. Brasília: Brasília Jurídica, 2. ed., 1998, p. 40.

121 "Art. 23 - Compete, ainda, privativamente, ao Tribunal Superior, $(\ldots)$

IX - expedir as instruções que julgar convenientes à execução deste Código;

$(\ldots)$

XII - responder, sobre matéria eleitoral, às consultas que lhe forem feitas em tese por autoridade com jurisdição, federal ou órgão nacional de partido político".
} 
competências atípicas da Justiça Eleitoral foram recepcionadas pelo texto de $1988^{122}$.

Além da grande carga administrativa, a Justiça Eleitoral deve ter a capacidade de editar instruções por causa da grande instabilidade legislativa já apontada anteriormente neste trabalho. O princípio da segurança jurídica na seara eleitoral fica mais coberto no momento que o TSE deixa mais nítida sua interpretação para toda sociedade, seja por meio de instruções regulamentares, seja por meio do procedimento consultivo ${ }^{123}$.

Suzana de Camargo Gomes ensina que as instruções aprovadas pelo TSE com base no inciso IX do art. 23 tratam-se de "atos normativos, com força regulamentar, e que são aprovados por meio de resoluções da Corte colegiada, tendo por fim ensejar uma melhor explicitação da lei para sua correta aplicação ${ }^{124}$. Há quem inclusive defenda que estas instruções têm força de lei ordinária ${ }^{125}$.

\footnotetext{
${ }^{122}$ A função normativa/regulamentar da Justiça Eleitoral estava prevista na legislação desde sua criação, com o advento do Código Eleitoral de 1932 (Decreto n. 21.076, de 24.02.1932). O art. 14, item 4, dispunha que cabia ao Tribunal superior "fixar normas uniformes para a aplicação das leis e regulamentos eleitorais, expedindo instruções que entenda necessárias". Já a competência consultiva da Justiça Eleitoral foi prevista pela primeira vez no Código Eleitoral de 1935 (Lei n. 48, de 04.05.1935), no art. 13, alínea "m", sendo função do Tribunal Superior "responder, sobre matéria eleitoral, às consultas que lhe sejam feitas por autoridades públicas ou partido registrado".

123 Concorda com o nosso posicionamento Eduardo Silva da Silva. Para ele, diante de "um verdadeiro pântano jurídico, inacessível de ser penetrado com segurança mesmo aos já iniciados", o mecanismo da consulta, por consistir na requisição a um órgão jurisdicional uma interpretação de uma regra jurídica, acarreta numa "verdadeira confissão pública de que, efetivamente, há muito tempo, a lei não oferece certeza ou segurança jurídica". ("Jurisdição e positivismo jurídico: breves reflexões sobre o procedimento de consulta na Justiça Eleitoral". In: Revista Forense, v. 350, abr./mai./jun. 2000, p. 435). 124 GOMES, Suzana de Camargo Gomes. "A competência da Justiça Eleitoral". In: Revista Brasileira de Direito Constitucional, n. 3, jan./jun. $2004, \mathrm{p} .717-718$.

125 LINS, Eloy d'Almeida. "Fontes materiais e formais do direito: organização e funcionamento da Justiça Eleitoral; e cláusula de
} 
No que tange à competência consultiva, há de se reconhecer que existem vantagens nesta previsão legal. A primeira delas é o fato de com a possibilidade de partido político ou detentor de mandato consultar o TSE, há uma tendência de garantia do princípio da segurança jurídica, uma vez que toda a sociedade adquire conhecimento das opiniões prestadas pela corte Eleitoral.

Corroboram com este aspecto Carlos Mário da Silva Velloso e Walber de Moura Agra, ao atestarem que "ao se anteceder às demandas [por meio do mecanismo consultivo], o Judiciário dissipa as dúvidas existentes acerca de determinados procedimentos ${ }^{126 \prime \prime}$.

Ademais, como tratam de hipóteses, e não de casos concretos, a decisão em sede de consulta não faz coisa julgada ${ }^{127}$.

No que toca à análise das competências normativa/regulamentar e consultiva da Justiça Eleitoral sob a ótica do fenômeno do ativismo judicial, a possível exacerbação dessas competências é fato reconhecido na doutrina brasileira. Gilberto Guerzoni Filho, por exemplo, sustenta que a Justiça Eleitoral, por ser a responsável pela disciplina do processo eleitoral, edita instruções

barreira legal". In: Revista ESMAFE - Escola de Magistratura Federal da 5a Região, n. 11, 2006, p. 81.

${ }^{126}$ Velloso, Carlos Mário da Silva; AGRA, Walber de Moura. Elementos de direito eleitoral. São Paulo: Saraiva, 2009, p. 17. No mesmo sentido, assevera Suzana de Camargo Gomes: "Neste particular, predomina o espírito pedagógico das decisões, de molde a realizar uma orientação no sentido de que sejam cumpridos os preceitos legais e regulamentares de toda a sua extensão" ("A competência da Justiça Eleitoral". In: Revista Brasileira de Direito Constitucional, n. 3, jan./jun. 2004, p. 717 ).

${ }^{127}$ No mesmo sentido, Suzana de Camargo Gomes. ("A competência da Justiça Eleitoral". In: Revista Brasileira de Direito Constitucional, n. 3, jan./jun. 2004, p. 721). 
"que, algumas vezes, (...) chegam, efetivamente, a criar direito ${ }^{128 "}$.

Do lado oposto, Rômulo Pizzolatti entende que nas competências normativa/regulamentar e consultiva, a Justiça Eleitoral tem exercício administrativo meramente. Na visão do autor, como as duas hipóteses não tratam de casos concretos, "não há falar em jurisdição, nem contenciosa, nem voluntária". Ademais, para Pizzolatti, "como se vinculam os órgãos judiciários ao direito positivo, tampouco se pode dizer que exerçam atividade legislativa. Tais atividades seriam, por exclusão, administrativas ${ }^{129 \prime \prime}$.

Nosso entendimento é o de que a Justiça Eleitoral exacerba os limites constitucionais e legais de suas competências normativa/regulamentar e consultiva.

Para comprovar este argumento, o próximo item trará a análise de uma série de decisões exaradas pelo Tribunal Superior Eleitoral e pelo Supremo Tribunal Federal em três questões fulcrais do sistema político-eleitoral brasileiro: (i) regras para coligações partidárias; (ii) fidelidade partidária; e (iii) requisitos de elegibilidade - o conceito de quitação eleitoral. Após, o capítulo seguinte trará exame pormenorizado da doutrina e da

\footnotetext{
128 GUERZONI FILHO, Gilberto. "A Justiça eleitoral no Brasil: a desconfiança como elemento fundamental de nosso sistema eleitoral". In: Revista de Informação Legislativa, ano 41, n. 161, jan./mar. 2004, p. 41. Pensa, da mesma forma, José Augusto Delgado, que alerta para a existência de uma "tendência sempre crescente dos operadores da Lei Eleitoral, quando da expedição do regulamento, em assentar regras que extrapolam os condutos hierárquicos postos no dispositivo normativo". ("A contribuição da Justiça Eleitoral para o aperfeiçoamento da democracia". In: Revista dos Tribunais, n. 718, ago./1995, p. 323). 129 PIZzolAtTI, Rômulo. "A natureza das atividades da Justiça Eleitoral". In: Resenha Eleitoral - nova série - TRE/SC, v.4, n.1, jan./jun. 1997, p. 27.
} 
jurisprudência sobre a questão da verticalização das coligações partidárias ${ }^{130}$.

\subsection{O fenômeno do ativismo judicial e a implantação da reforma política pelo Poder Judiciário}

Este item tem como escopo demonstrar que - ativismo judicial na Justiça Eleitoral brasileira, por meio principalmente da interpretação extensiva dos incisos IX e XII do art. 23 do Código Eleitoral, não se tratou de um evento pontual ou até casual.

$\mathrm{Na}$ verdade, desde $\mathrm{O}$ advento da Constituição de 1988 há diversas decisões do Tribunal Superior Eleitoral e também do Supremo Tribunal Federal nas mais diversas sedes processuais, como ações diretas de inconstitucionalidade, processo administrativo no TSE, consulta eleitoral, mandado de segurança e recurso extraordinário, que tangenciam o direito políticoeleitoral.

Neste item, serão focalizadas duas decisões tomadas pelo TSE e/ou pelo STF neste contexto. Por maio da análise delas, tentar-se-á evidenciar que o fenômeno estudado no capítulo anterior, qual seja, o ativismo judicial, vem sendo cada vez mais percebido nos meios acadêmicos, políticos e judiciais.

\footnotetext{
130 Corroborando com o nosso entendimento, Celso Jefferson Messias Paganelli e José Antonio Gomes Ignácio Junior dissertam que "na seara eleitoral, o Tribunal Superior Eleitoral, inobstante o déficit de legitimidade democrática desse poder, atua de forma acintosa de maneira proativa, quer pautado nos princípios constitucionais, quer puramente no ordenamento infra (Código Eleitoral - art. 23)". "Ativismo judicial nas resoluções da Justiça Eleitoral - duvidosa compatibilidade do artigo 23, IX e XVIII do Código Eleitoral com a Constituição Federal". In: Anais do XX Congresso Nacional do CONPEDI realizado em Vitória/ES. Florianópolis: Fundação Boiteux, 2012, p. 4163.
} 
O conflito aparente entre os Poderes Judiciário e Legislativo poderá ser verificado nos dois subitens subsequentes. A primeira grande polêmica judicial envolve a verticalização das coligações partidárias.

Após consulta feita por deputados federais filiados ao PDT, O TSE, em fevereiro de 2002, muda radicalmente seu conceito de coligações partidárias, fazendo surgir o princípio da coerência das coligações partidárias. Esta decisão foi contestada por duas vezes no STF, que manteve em todas as oportunidades a vigência da Resolução eleitoral. Somente o advento de uma Emenda Constitucional retirou a verticalização das coligações do ordenamento jurídico brasileiro. A análise das decisões exaradas no tema serão, diferentemente das duas a seguir, tratadas no capítulo 4 deste trabalho.

Assim sendo, a primeira série de decisões destacadas neste item trata da fidelidade partidária. O TSE, também em sede de consulta, decidiu modificar completamente o entendimento jurisprudencial e doutrinário sobre o tema, ao decidir que o mandato político (no Poder Legislativo e também no Executivo) pertence aos partidos políticos ao qual o político estava filiado no momento da eleição, e não à pessoa física eleita.

Ademais, o TSE criou, também por meio de Resolução, regras procedimentais para uma ação eleitoral visando à perda de mandato do político infiel. Não satisfeito, O TSE, na mesma norma, criou as hipóteses de transfuguismo partidário por justa causa, ou seja, em quais casos o político pode deixar sua agremiação para se filiar a outra sem perder seu mandato. Provocado, o STF confirmou 
a constitucionalidade da Resolução, bem como afastou as pretensões de partidos políticos para invalidar referida norma.

Por fim, será também abordado todo o contexto envolvendo a conceituação da certidão de quitação eleitoral. Prevista desde o advento da Lei das Eleições, em 1997, como requisito para o registro de candidatura, esta certidão ocasionou enorme polêmica no TSE, bem como no Congresso Nacional.

Por se tratar de importante condição legal de elegibilidade sem regulamentação legal, O TSE arvorou-se de sua competência prevista no art. 23 do Código Eleitoral e regulamentou a questão em 2004 por meio de Resolução.

A mudança de interpretação ocorrida em 2008 gerou reação do Congresso Nacional. A Minirreforma Eleitoral (Lei n. 12.034/2009) aprovada pelo Parlamento restringiu a possibilidade de interpretação do TSE no tema. Mesmo assim, O TSE divergiu por quatro vezes sobre a interpretação dessa nova norma, somente pacificando-a em meados de 2012 .

Assim sendo, este capítulo tentará demonstrar, por meio de duas séries de decisões, de aspectos bastante diferentes do direito partidárioeleitoral brasileiro (coligações partidárias, fidelidade partidária e condições de elegibilidade), o quanto a influência do Poder Judiciário tem crescido no cenário político brasileiro. 


\subsubsection{Fidelidade Partidária (2007)}

Neste subitem, trata-se do instituto da fidelidade partidária e das decisões do TSE e do STF sobre - tema. O fato de uma mudança radical da jurisprudência no tema ter como origem a resposta do TSE a uma consulta formulada por um partido político nos parece suficiente para a fidelidade partidária ganhar grande destaque diante do objetivo final e principal deste trabalho.

As "idas e vindas" da jurisprudência, bem como as consequências da decisão final do Supremo Tribunal Federal sobre a existência da fidelidade partidária na sistemática constitucional de 1988 servirá como reforço ao argumento de que o Judiciário tem ultrapassado suas competências legais e constitucionais diante dos critérios já estudados no capítulo anterior.

Inicialmente, será feito um exame da evolução constitucional histórica do tema, desde o advento da Emenda Constitucional n. 1, de 1969, até a promulgação da Constituição de 1988. Em seguida, será apresentado o fenômeno decorrente destas mudanças constitucionais e infraconstitucionais sobre a fidelidade partidária: a intensa e descontrolada migração de parlamentares. Serão objeto deste trecho os motivos teóricos apresentados pela doutrina para este fenômeno. Finalmente, a análise das principais decisões proferidas pelo TSE e pelo STF completa o estudo.

O instituto da fidelidade partidária surgiu no ordenamento jurídico brasileiro com o advento da Constituição da República Federativa do Brasil de 1967, outorgada pelo Presidente da República General Arthur da 
Costa e Silva, no início do endurecimento do Regime Militar de 1964. Para se entenderem os motivos que levaram o Regime Militar a impor no texto constitucional referido instituto, será necessária uma rápida análise do contexto histórico e político da época.

O Regime Militar derrubou o governo constitucional do Presidente João Goulart em 31 de março de 1964. Entre diversas medidas nos mais variados campos legislativos, podemos destacar, no âmbito eleitoral, no início do Regime, a criação de um novo Código Eleitoral, o adiamento da eleição presidencial prevista para ocorrer em 1965 e, por fim, a extinção dos partidos políticos existentes no período democrático de 1946-1964.

O Ato Institucional n. 1 , de 9 de abril de 1964, mantinha o calendário eleitoral e os partidos políticos então existentes. Em 15 de julho de 1965, veio à tona o Código Eleitoral (Lei n. 4.737, atualmente em vigor) e também uma nova Lei Orgânica dos Partidos Políticos (Lei n. 4.740 - LOPP(65). Nesta norma, havia a determinação de que os partidos deveriam ser reorganizados. Não houve, porém, fixação de prazo.

A LOPP/65 também estabeleceu cláusula de desempenho pré-eleitoral aos partidos brasileiros. Assim, para confirmar seu registro eleitoral, o partido deveria receber apoio de listas de eleitores. Esta lista deveria conter ao menos 3\% do eleitorado que tivesse votado na última eleição à Câmara dos Deputados, devendo os eleitores listados serem distribuídos em 11 (onze) ou mais estados, com um mínimo de $2 \%$ em cada um deles. 
Nas eleições seguintes, os partidos também deveriam respeitar uma cláusula de desempenho eleitoral: se o partido não elegesse ao menos 12 (doze) deputados federais, distribuídos em, no mínimo, sete estados da federação, ele teria seu registro cancelado, mesmo se houvesse cumprido a cláusula pré-eleitoral. Havia, assim, clara intenção de diminuir o número de partidos no sistema brasileiro ${ }^{131}$.

Após a derrota do partido mais ligado ao Regime Militar nas eleições estaduais de 1965 (a União Democrática Nacional), o Regime decretou 0 Ato Institucional n. 2, de 27 de outubro de 1965. Nele, houve a determinação de que as eleições presidenciais passariam a ser realizadas por meio de um Colégio Eleitoral, bem como decidiu pela extinção de todos os partidos políticos em funcionamento.

- Ato Complementar n. 4, de 20 de novembro de 1965, trouxe as regras para a criação de partidos políticos. Referido Ato dispunha que caberia aos congressistas a iniciativa de criar organizações com atribuições de partidos para a disputa das eleições legislativas a serem realizadas no ano seguinte ${ }^{132}$.

O AC n. 4 previa o prazo de 45 dias para que as organizações fossem formadas. Este prazo foi

\footnotetext{
131 No mesmo sentido, Rogério Schmitt, que realçou este fato ao, hipoteticamente, cruzar estas informações com os resultados eleitorais do escrutínio de 1962. Segundo Schmitt, apenas cinco partidos teriam sobrevivido. Partidos políticos no Brasil (1945-2000). Rio de Janeiro: Jorge Zahar Ed., 2000, p. 29.

132 "Art. $1^{\circ}$ Aos membros efetivos do Congresso Nacional, em número não inferior a 120 deputados e 20 senadores, caberá a iniciativa de promover a criação, dentro do prazo de 45 dias, de organizações que terão, nos têrmos do presente Ato, atribuições de partidos políticos enquanto êstes não se constituírem."(sic)
} 
prorrogado até 15 de março de 1966 por meio do Ato Complementar n. 6, de 3 de janeiro de 1966.

O AC n. 4 determinava, em seu art. $1^{\circ}$, que estas organizações partidárias tivessem, para efeito de registro, a filiação de, no mínimo, 120 de deputados federais e 20 senadores. Na época, a Casa Baixa do Congresso Nacional tinha, no total, 409 membros. Já o Senado Federal compunha-se de 66 cadeiras.

É possível perceber, nitidamente, que a intenção do regime militar era por uma formação forçada de um regime bipartidário. Matematicamente, era possível a criação de, no máximo, três organizações partidárias. Não queria, porém, que houvesse a criação de um sistema monopartidário ${ }^{133}$.

Além de ter como objetivo exterminar o sistema partidário do período democrático de 1946-1964, a Ditadura também tinha como escopo, ao forçar o bipartidarismo, arregimentar em apenas dois partidos o apoio e a oposição ao Regime Militar ${ }^{134}$. O sistema

${ }^{133}$ Corrobora com este pensamento Rogério Schmitt: "Se, por um lado, o regime autoritário queria evitar a criação de um sistema de partido único, por outro também não queria reproduzir a alegada fragmentação partidária do período precedente. Restava então a alternativa do bipartidarismo, característico das democracias anglo-saxãs (Estados Unidos e Inglaterra, por exemplo)". Partidos políticos no Brasil (1945-2000). Rio de Janeiro: Jorge Zahar Ed., 2000, p. 32.

${ }^{134}$ No mesmo sentido, Boris Fausto: "Mas a medida mais importante do AI2 foi a extinção dos partidos políticos existentes. Os militares consideravam que o sistema multipartidário era um dos fatores responsáveis pelas crises políticas. Desse modo, deixaram de existir os partidos criados no fim do Estado Novo que, bem ou mal, exprimiam diferentes correntes da opinião pública. A legislação partidária forçou na prática a organização de apenas dois partidos: a Aliança Renovadora Nacional (ARENA), que agrupava os partidários do governo, e - Movimento Democrático Brasileiro (MDB), que reunia a oposição. A maior parte dos políticos que se filiaram à ARENA tinha pertencido à UDN e em número quase igual ao PSD; O MDB foi formado por figuras do PTB, vindo a seguir o PSD". História do Brasil. São Paulo: Editora da Universidade de São Paulo, 10 ed., 2002, p. 474-475. 
bipartidário resumir-se-ia a uma forma binomial: uma legenda pró-Regime e um partido de oposição. Desta forma, tentar-se-ia, ao menos, trazer alguma aura de democracia a um Regime que, na verdade, caminhava para a radicalização.

No anseio de uma rápida reforma das instituições brasileiras, o Regime outorgou nova Constituição em 24 de janeiro de 1967. A oposição, no entanto, começou a arregimentar forças e os protestos de rua foram intensificados. Diante desse quadro, o Regime Militar baixou duas medidas drásticas: o Ato Institucional n. 5 e a Emenda Constitucional n. 1/1969.

O AI-5 foi uma norma brutal. Com ele, o Presidente da República poderia cassar direitos políticos de opositores, intervir nos Estados-membros e nos Municípios, bem como demitir ou aposentar servidores públicos. A garantia clássica do habeas corpus foi suspensa para aqueles que respondiam por crimes contra a segurança nacional ou contra a ordem econômica e social e a economia popular.

A doença que acometeu Costa e Silva, em agosto de 1969, trazia a oportunidade prevista na Constituição de 1967 para a assunção do vice-presidente civil Pedro Aleixo. Por meio do Ato Institucional n. 12, de 31 de agosto de 1969, porém, assumiu o poder uma Junta Militar formada pelos ministros de cada Força Armada brasileira.

Já no final do período em que o governo federal foi formado por um triunvirato, foi outorgada a Emenda Constitucional n. 1, de 17 de outubro de 1969. Ela 
previa a mudança de vários artigos da Constituição de 1967 sendo às vezes considerada, na prática, uma nova Carta.

Para o item em análise, porém, ela foi de enorme importância: foi esta norma que previu, pela primeira vez no Brasil, o instituto da fidelidade partidária, conforme pode se depreender do texto em seguida:

“Art. 35. Perderá o mandato o deputado ou senador:

(...)

V - que praticar atos de infidelidade partidária, segundo o previsto no parágrafo único do artigo 152."

Além de prever uma nova hipótese constitucional para a perda de mandato do congressista, a EC n. 1/1969 previa também as hipóteses de fidelidade partidária, in verbis:

"Art. 152. A organização, o funcionamento e a extinção dos partidos políticos serão regulados em lei federal, observados os seguintes princípios:

(...)

(...)

Parágrafo único. Perderá o mandato no Senado Federal, na Câmara dos Deputados, nas Assembleias Legislativas e nas Câmaras Municipais quem, por atitudes ou pelo voto, se opuser às diretrizes legitimamente estabelecidas pelos órgãos de direção partidária ou deixar o partido sob cuja legenda foi eleito. A perda do mandato será decretada pela Justiça Eleitoral, mediante representação do partido, assegurado o direito de ampla defesa."

152 da EC. 1/1969 traz à tona dois conceitos importantes para o estudo do tema na evolução constitucional brasileira.

Primeiramente, prevê que os partidos seriam regidos pelo princípio da disciplina partidária. Fica, portanto, nítida a preocupação do Regime Militar em garantir que os partidos (na prática, a ARENA) tratassem em seus estatutos partidários das hipóteses de punição aos 
filiados que não respeitassem as diretrizes partidárias (ou seja, as orientações do governo).

Ademais, a Emenda também dispôs sobre punição de perda do mandato para aqueles que se dispusessem a trocar de partido. Por fim, previa-se que eventual discussão judicial sobre a perda do mandato por infidelidade partidária seria de competência da Justiça Eleitoral ${ }^{135}$, sendo assegurada a ampla defesa ao trânsfuga.

Este quadro durou até outubro de 1978. Nesta época, já havia ocorrido mudanças no contexto político brasileiro. A ditadura militar vinha perdendo força e, por consequência, a ARENA tinha maiores dificuldades em formar a maioria nas duas Casas do Congresso Nacional. No intuito de manter, mesmo que artificialmente, a força política da ARENA, o governo do General Ernesto Geisel não se furtou a realizar diversas mudanças casuísticas na legislação eleitoral e também no texto constitucional.

Primeiramente, o regime mudou os dispositivos que tratavam da propaganda eleitoral no rádio e na televisão. O advento da Lei n. 6.339, de 01.07.1976, chamada de "Lei Falcão" (por ser de autoria do então Ministro da Justiça, Armando Falcão) prejudicou as possibilidades de o MDB apresentar suas propostas nos dois principais meios de publicidade eleitoral.

\footnotetext{
135 “Art. 137. A lei estabelecerá a competência dos juízes e Tribunais Eleitorais, incluindo entre as suas atribuições: $(\ldots)$

IX - a decretação da perda de mandato de senadores, deputados e vereadores nos casos do parágrafo único do artigo 152".
} 
A Emenda Constitucional n. 8, de 14 de abril de 1977, conhecida como "Pacote de Abril", trouxe duas novas mudanças importantes ao sistema político brasileiro. A primeira delas foi o aumento do número de cadeiras na Câmara dos Deputados aos Estados da Região Norte, Nordeste, unidades federativas nas quais a ARENA tinha maior sucesso eleitoral.

A segunda alteração tratou da criação da figura do "senador biônico". Das três cadeiras no senado Federal que cada Estado-membro tinha direito, uma delas seria escolhida pela respectiva Assembleia Legislativa, retirando, por consequência, a possibilidade do voto popular.

Já a Emenda n. 11/1978 previa uma exceção às regras da fidelidade partidária. $0 \$ 5^{\circ}$ do art. 152 dispunha sobre o tema da seguinte forma:

"Art. 152 - A organização e o funcionamento dos partidos políticos, de acordo com o disposto neste artigo, serão regulados em lei federal.

(...)

$\S 5^{\circ}$ - Perderá o mandato no senado Federal, na Câmara dos Deputados, nas Assembleias Legislativas e nas Câmaras Municipais quem, por atitude ou pelo voto, se opuser às diretrizes legitimamente estabelecidas pelos órgãos de direção partidária ou deixar o partido sob cuja rege for eleito, salvo se para participar, como fundador, da constituição de novo partido."

Esta exceção consistia na possibilidade de o congressista não perder o mandato se saísse de seu partido de origem para participar, como fundador, da constituição de novo partido.

Esta mudança tinha endereço certo. Neste momento, qual seja, o início da crise política do Regime Militar, era interessante para os detentores do Poder encerrar o sistema bipartidário forçado. Os militares 
imaginavam que se abrindo esta exceção, haveria a implosão do MDB, partido de oposição, facilitando, consequentemente, - controle do Congresso Nacional pelo partido de apoio ao regime.

Essa possibilidade foi verificada na prática. O disposto na EC n. 11/1978, somado ao advento da Lei n. 6.767, de 20.12.1979, dinamitou o sistema bipartidário: a ARENA tornou-se O PDS (Partido Democrático Social) e o MDB se dividiu em várias novas legendas ${ }^{136}$.

Nas eleições de 1982, diante do novo quadro partidário, a Ditadura empreendeu novas mudanças na legislação político-eleitoral visando a garantir o sucesso eleitoral do PDS. A Lei n. 6.978, de 19.01.1982, previa a obrigatoriedade do voto vinculado: em todos os cargos em disputa na eleição de 1982, o eleitor deveria votar sempre no mesmo partido, sob pena de nulidade de todos os seus votos.

Ademais, referida norma determinou que os partidos deveriam lançar candidatos para todos os cargos eletivos em disputa. Se a agremiação não conseguisse realizar tal feito, não poderia lançar nenhuma candidatura naquele Estado-membro.

Essas duas novas regras criavam enormes dificuldades para os partidos de oposição recém-fundados, já que eles não tinham uma rede de infraestrutura partidária muito firme e longa. Foram favorecidos,

\footnotetext{
136 Tiveram como origem $\bigcirc$ MDB os seguintes partidos: PMDB (Partido do Movimento Democrático Brasileiro), PTB (Partido Trabalhista Brasileiro), PDT (Partido Democrático Trabalhista), PT (Partido dos Trabalhadores) e, por fim, O PP (Partido Popular). Os quatro primeiros permanecem no sistema partidário brasileiro. Já o PP teve vida efêmera, sendo incorporado pelo PMDB em 1982.
} 
consequentemente, O PDS e O PMDB, partidos que já contavam com maior estrutura por serem os sucessores dos finados ARENA e MDB, respectivamente.

Com o final da Ditadura Militar, em 15 de março de 1985, data em que assumiu a Presidência da República o civil José Sarney, houve a preocupação do Congresso em trazer à baila uma nova legislação políticoeleitoral. No que tange à fidelidade partidária, ela foi extinta pelo advento da Emenda Constitucional n. 25, de 15 de maio de 1985. Rogério Schmitt destaca que, na época, imaginava-se que o "entulho autoritário' começava a ser removido ${ }^{137 "}$.

Poucos anos depois, foi convocada uma Assembleia Nacional Constituinte. Nela, houve discussões acerca da previsão constitucional ou não do instituto da fidelidade partidária. O texto original na Constituição de 1988 previa a fidelidade partidária, mas de forma diametralmente diferente da disposta no texto constitucional do Regime Militar. $O \$ 1^{\circ}$ do art. 17 determina que cabia aos partidos políticos, ante sua autonomia, estabelecer obrigatoriamente, em seus estatutos, normas de fidelidade e disciplina partidárias. Ademais, não há qualquer previsão no art. 55, que trata das hipóteses de perda de mandato dos congressistas, tratando do tema.

No tocante à legislação infraconstitucional, a Lei dos Partidos Políticos (Lei n. $9.096 / 1995$ - LPP) prevê, nos arts. 23 a 26, a regulamentação da disposição constitucional sobre a fidelidade e disciplina partidária. Também a LPP não traz

137 SCHMITT, Rogério. Partidos políticos no Brasil (1945-2000). Rio de Janeiro: Jorge Zahar Ed., 2000, p. 61. 
qualquer disposição sobre eventual pena àquele que troque de partido durante o exercício do mandato.

Em outra oportunidade, analisamos o tema, ao lado de Rafael Rocha de Macedo, no sentido de que

"essa ampla autonomia concedida pelo texto constitucional aos partidos políticos reflete um posicionamento do constituinte, no sentido de evitar os excessos e os abusos de autoridade cometidos pelo regime militar e pelos líderes partidários daquela época $^{138139, "}$

Diante do quadro normativo, houve um fenômeno bastante evidente e, por isso, bastante estudado no Brasil: o descontrole no número de mudanças partidárias entre pessoas que exerciam cargos eletivos no Legislativo e também no Executivo.

Além de evidente, o tema é de suma
importância para o funcionamento do sistema político
brasileiro. Primeiramente, deve-se ressaltar o fato de
mudanças sem controle de partidos por parte de
parlamentares afetam diretamente o resultado das urnas
populares.

Vigendo o sistema proporcional de lista aberta para quase todos os cargos do Legislativo, o voto dado a um candidato também foi dado ao seu partido. Mudando de legenda, há uma contrariedade à lógica do sistema proporcional.

\footnotetext{
138 REIS, Daniel Gustavo Falcão Pimentel dos; MACEDO, Rafael Rocha de. "O partido político e as campanhas eleitorais brasileiras: sistema normativo, propostas de reforma legislativa e as recentes decisões do Supremo Tribunal Federal". In: CAGGIANO, Monica Herman Salem (org.). Comportamento eleitoral. Barueri, Manole, 2010, p. 183.

139 Thales Tácito Cerqueira e Camila Cerqueira afirmam, no mesmo sentido defendido por este autor, que cabe, conforme o texto constitucional, a cada partido, em seu estatuto, "estabelecer como deveria funcionar internamente o mecanismo de controle sobre as decisões de seus representantes eleitos. "Fidelidade partidária: a insegurança jurídica". In: Revista Jurídica Consulex, ano XI, n. 268, 15.03.2008, p. 33.
} 
Além disso, os partidos de oposição, principalmente, percebiam uma notável redução no número de parlamentares. Consequentemente, perdiam força na batalha diária dentro do Congresso contra a base governista. Carlos Ranulfo Melo analisa o espectro então vigente nos primeiros anos pós-Constituição de 1988, conforme trecho a seguir:

"Transformada em prática corrente, a troca de legenda passou a vigorar como instrumento suplementar de modificação da correlação de forças no Congresso, com impacto diferenciado sobre o desempenho dos sistemas partidários estaduais, a constituição das coalizões governamentais e o grau de representatividade do sistema partidário nacional. Tornou-se ainda, na medida em que ganhou destaque na mídia, parte do rol de atividades que, na percepção da população, contribuem para situar o Congresso e os partidos nos últimos lugares em qualquer pesquisa que se faça acerca da credibilidade das instituições no país ${ }^{140 "}$.

O descontrole das migrações partidárias tem diversas explicações. A primeira delas advém das origens do atual sistema partidário brasileiro. o rompimento com o sistema vigente no período democrático de 1946-1964 fez com que o sistema atual tivesse como real origem o bipartidarismo forçado do Regime Militar.

Assim, a grande maioria dos atuais partidos brasileiros sofre do fraco enraizamento na sociedade. O Ato Complementar n. 4, como já analisado, forçou as organizações partidárias terem seu nascimento nos corredores do Congresso Nacional. Hoje, se vê raras exceções a esta realidade. A maior parte dos partidos

\footnotetext{
${ }^{140}$ MELO, Carlos Ranulfo. "Migração partidária na Câmara dos Deputados: causas, consequências e possíveis soluções". In: BENEVIDES, Maria Victoria; VANNUCHI, Paulo; KERCHE, Fábio (orgs.). Reforma política e cidadania. São Paulo: Fundação Perseu Abramo, 2003, p. 322.
} 
políticos brasileiros nasce por decisões advindas de políticos, e não por iniciativa popular ${ }^{141}$.

Não há identificação partidária na população brasileira. Desde o início do governo civil, em 1985, houve um exacerbação no número de partidos criados. Naquela época, nota-se que as regras eleitorais para a criação de partidos era bastante frouxa. Os partidos políticos poderiam concorrer nas eleições mesmo sem registro definitivo no TSE. Não obstante, foi permitido o retorno das coligações partidárias nas eleições proporcionais e, por fim, acesso à propaganda partidária e eleitoral a todos os partidos concorrentes.

Todas estas mudanças facilitaram a proliferação dos partidos políticos. O pluripartidarismo exacerbado, confirmado pela Constituição de 1988, trazia boas condições práticas para mandatários interessados em migrar de seu partido original.

Ao mudar de partido, o político verificará se suas condições políticas melhorarão. Ranulfo Melo cita, por exemplo, que muitos congressistas se interessavam em mudar de partidos para assumir a direção estadual ou municipal de sua nova legenda, ganhando assim mais poder. Esse poder poderia ser verificado na hora de barganhar uma coligação eleitoral com os partidos maiores,

\footnotetext{
${ }^{141}$ Carlos Enrique Guzmán Mendoza e Ermício Sena de Oliveira trazem como exemplo de partidos com origem popular no Brasil o PT, advindo de movimento paredista denominado 'Novo Sindicalismo' e, também, o PDT, fruto do encontro de trabalhadores liderados por Leonel Brizola. "Brasil". In: ALCÁNTARA, Manuel; FREIDENBERG, Flavia (coords.). Partidos políticos de América Latina: Cono Sur. México: FCE/IFE, 2003, p. 121 e 172 .
} 
sendo a principal moeda de troca o tempo de propaganda eleitoral no rádio e na televisão ${ }^{142}$.

Scott Mainwaring corrobora com esse posicionamento. Os partidos brasileiros, segundo ele, não têm raízes profundas na sociedade, não gozam de identificação junto aos eleitores e, por fim, não têm legitimidade pública, ou seja, têm baixa credibilidade. A adoção do sistema proporcional de lista aberta somada a fragilidade institucional dos partidos no Brasil acarretam no individualismo dos filiados tanto nas campanhas eleitorais como no exercício do mandato político ${ }^{143}$.

Outro fator que poderia explicar 0 fenômeno ora debatido é a forte centralização dos poderes no Congresso Nacional. A Mesa das duas Casas Legislativas, bem como o Colégio de Líderes ditam a agenda e o ritmo de votações no Congresso. Na verdade, este fato pode possivelmente também explicar os motivos para tantas trocas partidárias, mas não para eventual indisciplina partidária, como poderemos analisar em breve.

O principal motivo, porém, é prático. Na opinião de Carlos Ranulfo Melo, havia muitas trocas partidárias pelo fato de o congressista ter muita incerteza sobre o futuro de sua carreira parlamentar. Este ângulo no exame da questão baseia-se no seguinte fato: a taxa de reeleição no Congresso Nacional é baixa.

142 Cf. MELO, Carlos Ranulfo. "Migração partidária na Câmara dos Deputados: causas, consequências e possíveis soluções". In: BENEVIDES, Maria Victoria; VANNUCHI, Paulo; KERCHE, Fábio (orgs.). Reforma política e cidadania. São Paulo: Fundação Perseu Abramo. 2003, p. 328. ${ }^{143}$ Cf. MAINWARING, Scott. Sistemas partidários em novas democracias: o caso do Brasil. Porto Alegre: Mercado Aberto; Rio de Janeiro: Editora FGV, 2001, p. 127-128. 
Diante disso, o parlamentar percebe que, na maioria das oportunidades, há um baixo custo perante a sociedade de trocar de partido. Seus possíveis eleitores, em tese, não se incomodariam com a migração. Somado a isto, a legislação era, até 2007 (a decisão do TSE exarada neste ano mudou a interpretação do Judiciário no tema e, no âmbito deste trabalho, é o principal objeto deste item), bastante permissiva ${ }^{144}$ : não havia grandes consequências para - parlamentar migrante ${ }^{145}$. Na verdade, a única consequência era a perda de eventual posto em comissão parlamentar.

Para comprovar esta tese, verifica-se que os principais períodos de mudança de partidos eram os meses de janeiro e fevereiro e setembro e outubro dos primeiro e terceiro anos da Legislatura.

A explicação para estes quatro períodos concentrarem as migrações partidárias é bastante simples. No primeiro ano da Legislatura, janeiro e fevereiro é o período em que os parlamentares eleitos tomam posse. Assim, mudar de partido pode ser benéfico ao visar a uma posição numa comissão parlamentar mais importante. Ademais, tratase do primeiro momento possível para o congressista migrar após saber do resultado eleitoral das urnas, ou seja, mudar de partido poderia significar a possibilidade de indicação

\footnotetext{
144 Adriano Sant'Ana Pedra ensina que, apesar de não haver previsão taxativa no texto da Constituição tratando da perda de mandato por infidelidade partidária, a previsão de que cabia aos estatutos partidários prever normas de fidelidade partidária eram, na prática, inócuas: "Se a Constituição pretendeu, com tal reserva, afastar a ingerência do Estado na autonomia dos partidos, por outro lado, também desejou o dever de fidelidade. Além disso, a sanção máxima que pode ser prevista no estatuto partidário - expulsão - não produz quaisquer efeitos retributivo ou preventivo que são inerentes aos sistemas partidários". "A construção judicial da fidelidade partidária no Brasil". In: Revista Brasileira de Estudos Constitucionais - RBEC, ano 2 , n. 6, abr. 2008 .

145 Cf. MELo, Carlos Ranulfo. Retirando as cadeiras do lugar: migração partidária na Câmara dos Deputados (1985-2002). Belo Horizonte: Editora da UFMG, 2002, p. 59-64.
} 
de cabos eleitorais e conhecidos a cargos no novo governo federal.

Em janeiro e fevereiro do terceiro ano da Legislatura, a explicação é praticamente a mesma: com o resultado das eleições municipais, o parlamentar poderia arregimentar novas vantagens ao conhecer o resultado da votação popular. Já as migrações partidárias nos meses de setembro e outubro do primeiro e terceiro ano da Legislatura têm uma explicação em comum: tratava-se do final do prazo previsto na legislação visando a eventual candidatura nas eleições municipais (primeiro ano) e nas eleições gerais (terceiro ano), nas quais ele decidirá sua sorte ao tentar a reeleição ${ }^{146}$.

Caracterizado o quadro da infidelidade partidária vigente até 2007, a disciplina partidária não sofria dos mesmos problemas.

Argelina Figueiredo e Fernando Limongi demonstraram que a alta concentração dos poderes decisórios do Congresso, por meio das Mesas e do Colégio de Líderes, teve como principal consequência o alto índice de

146 Cf. MELO, Carlos Ranulfo. "Migração partidária na Câmara dos Deputados: causas, consequências e possíveis soluções". In: BENEVIDES, Maria Victoria; VANNUCHI, Paulo; KERCHE, Fábio (orgs.). Reforma política e cidadania. São Paulo: Fundação Perseu Abramo. 2003, p. $330-$ 331. No mesmo sentido, Simone Diniz, que acrescenta que, em algumas ocasiões, os partidos políticos tinham interesse em receber migrantes para aumentar seu tempo disponível na propaganda eleitoral no rádio e na televisão nas eleições seguintes: "Há fortes indícios de que parte das trocas de legendas foi motivada pelas normas estabelecidas na legislação, ao definirem os prazos limites para deferimento das novas filiações partidárias, e para a contagem da representação partidária para efeito da distribuição do tempo de propaganda gratuita na televisão e no rádio". DINIZ, Simone. "As migrações partidárias e o calendário eleitoral". In: Revista de Sociologia e Política, n. 15, nov. 2000, p. 45 . 
disciplina partidária, ou seja, houve poucos momentos em que congressistas votaram contra a indicação do líder de seu partido. Mais raro ainda, segundo os cientistas políticos, foram as ocasiões em que os parlamentares votaram contra sua ideologia.

Primeiramente, é forçoso notar que o Colégio de Líderes realmente concentra muito poder. Formado por líderes partidários e de blocos parlamentares, o Colégio, conforme disposição do Regimento Interno da Câmara dos Deputados, pode propor convocações extraordinárias, requerer a prorrogação da duração de uma sessão e apontar quais propostas terão caráter preferencial.

Assim sendo, Figueiredo e Limongi defendem que, no Congresso Nacional, os partidos políticos detêm considerável força, sendo bastante provável prever o resultado das votações, bem como definir sua orientação ideológica:

“Os partidos políticos na Câmara não são peças de ficção. A filiação partidária nos diz mito a respeito do voto provável do parlamentar. As votações costumam dividir o plenário de acordo com padrões ideológicos clássicos: há uma direita, há um centro e há uma esquerda. Além disso, já uma centro-direita e uma centroesquerda. Dito de outra maneira: o que temos é uma alta fragmentação nominal a esconder uma baixa fragmentação real ${ }^{147, "}$.

$$
\text { Trazido o contexto histórico, }
$$

constitucional e político, passaremos à análise das decisões proferidas pelo STF e pelo TSE no tema, decisões estas que mudaram radicalmente o entendimento vigente sobre a questão e que também exemplificam a exacerbação das funções consultiva e regulamentar do Tribunal Superior Eleitoral.

${ }^{147}$ FIGUEIREDO, Argelina; LIMONGI, Fernando. Executivo e legislativo na nova ordem constitucional. Rio de Janeiro: Editora FGV, 2 ed., 2001 , p. 93. 
A primeira decisão relevante proferida pelo STF no tema foi em 1989, ou seja, pouco depois da promulgação da Constituição de 1988. Trata-se do Mandado de Segurança n. 20.927-5/DF. Referido acórdão, relatado pelo Ministro Moreira Alves, foi indeferido, por maioria de votos.

O caso concreto se resume ao seguinte: um suplente de uma coligação formada na eleição de 1986 para a Câmara dos Deputados no Rio Grande do Norte requereu, administrativamente, sua posse como deputado federal para o Presidente da Câmara dos Deputados, sob a alegação de que o suplente anterior não poderia tomar posse por ter trocado de partido. O pedido foi negado pelo presidente da Câmara.

Assim, o impetrante argumentou, no STF, que seu direito líquido e certo à posse foi violado, já que "o suplente que se desliga do partido coligado perde a condição de suplente pela coligação148".

O Min. Moreira Alves votou pelo indeferimento do pedido, no qual foi acompanhado pela maioria. Consignou em seu voto que a Constituição de 1988 não adotou o princípio da fidelidade partidária. Mesmo havendo acentuado valor à representação partidária no texto constitucional e reconhecendo que a maioria dos parlamentares consegue eleger-se somente com os votos angariados por seus respectivos partidos, o constituinte deixou nítida a intenção de não prever qualquer sanção jurídica para aquele parlamentar que troca de partido. Nas palavras do Ministro Relator, "se o quisesse, bastaria ter

${ }^{148} \mathrm{MS}$ n. 20.927/DF, Rel. Min. Moreira Alves, j. 11.10.1989. 
colocado essa hipótese entre as causas de perda de mandato, a que alude o artigo $55^{149 \prime \prime}$.

A alegação de que o mandato, na verdade, pertence ao partido, também foi afastada pelo Relator. Para Moreira Alves, a vinculação constitucional obrigatória da candidatura a um partido (art. 14, $\$ 3^{\circ}, \mathrm{CRFB}$ ) não passa de mera condição de elegibilidade. Tanto é que a filiação a partido político não era condição para que o eleito diplomado tomasse posse.

Por fim, reconhece o Ministro Moreira Alves que "a lógica do sistema de representação proporcional e o valor que a atual constituição empresa à representação parlamentar federal do partido exigiam que a Carta Magna adotasse esse mínimo de fidelidade partidária que é o da permanência do Partido pelo qual o candidato se elegeu ou obteve a suplência". No entanto, a falta de previsão constitucional de punir quem troca de partido, bem como a previsão infraconstitucional de o diplomado poder tomar posse sem qualquer filiação partidária o convenceram de que o mandado de segurança deveria ser indeferido. No mesmo sentido, votaram os Ministros Sepúlveda Pertence, Célio Borja, Octavio Gallotti, Francisco Rezek, Aldir Passarinho e Néri da Silveira.

A divergência foi aberta pelo Ministro Celso de Mello, que relembrou histórica decisão acerca da legalidade do PCB no período político iniciado em 1946.

\footnotetext{
${ }^{149}$ MS n. 20.927/DF, Rel. Min. Moreira Alves, j. 11.10.1989. No mesmo sentido, O Min. Aldir Passarinho asseverou que "não houve (...) omissão na Constituição em não estabelecer o princípio de perda do mandato por infidelidade partidária, pois o tema sempre esteve presente. E tanto é certo que na Constituição anterior, que não podia ser naturalmente esquecida dos novos constituintes, havia regra expressa nesse sentido, a qual foi, como disse, amenizada pela Emenda Constitucional $\mathrm{n}^{\circ} 11^{\prime \prime}$.
} 
Esta decisão, segundo ele, demonstra que o mandato é do partido político, uma vez que ao se cassar o registro do PCB, foram automaticamente cassados os mandatos de todos aqueles filiados à agremiação comunista.

Paulo Brossard corroborou com 0 entendimento divergente, destacando o papel fundamental do partido político na nova ordem constitucional brasileira. Asseverou que ao manter a representação proporcional, houve a manutenção "implícita" da fidelidade partidária.

Votaram com a divergência também os Ministros Carlos Madeira e Sydney Sanches.

Por fim, vale destacar trecho do voto do Min. Francisco Rezek ao homenagear a minoria: "Sei que o futuro renderá homenagem à generosa inspiração cívica da tese que norteou os votos dos eminentes Ministros Celso Mello, Paulo Brossard, Carlos Madeira e Sydney Sanches"150". Indubitavelmente, a interpretação do TSE e do STF sobre o tema a partir de 2007 demonstrou ter o Ministro Rezek toda a razão.

A segunda vez que o STF se deparou com a questão da fidelidade partidária foi em 2004, no julgamento do Mandado de Segurança n. 23.405-9/Go. O Ministro Relator, Gilmar Mendes, votou por julgar prejudicado o mandado, voto pelo qual foi acompanhado por unanimidade pelo Plenário.

Esta decisão se deu pelo fato de a discussão, no caso concreto, se adstringir à Legislatura 1999-2003. A impetração, portanto, não tinha mais objeto.

${ }^{150} \mathrm{MS}$ n. 20.927/DF, Rel. Min. Moreira Alves, j. 11.10.1989. 
No entanto, vale ressaltar que a afirmação final do voto de Gilmar Mendes:

"Embora a troca de partidos por parlamentares eleitos sob regime da proporcionalidade revele-se extremamente negativa para o desenvolvimento e continuidade do sistema eleitoral e do próprio sistema democrático, é certo que a Constituição não fornece elementos para que se provoque o resultado pretendido pelo requerente [perda do mandato de dois suplentes à frente do impetrado na lista de sua coligação nas eleições de 1998] ${ }^{151}$ ", (grifos nossos).

A decisão que mudou todo o paradigma jurisprudencial no que tange à fidelidade partidária foi proferida pelo Tribunal Superior Eleitoral, em sede de Consulta, em 2007.

O PFL (Partido da Frente Liberal, hoje DEM - Democratas) apresentou ao TSE a Consulta n. 1.398, com base na seguinte pergunta: havia a possibilidade de o político exercendo cargo no Legislativo perder seu mandato por infidelidade partidária, mesmo não havendo previsão taxativa no art. 55 da Constituição? No mesmo sentido, o deputado federal Nilson Mourão (PT/Acre) também apresentou consulta com o objetivo de saber se a fidelidade partidária também vigoraria àqueles que ocupassem cargos majoritários.

O PFL baseava sua consulta em dois argumentos. O primeiro dele era o fato de o art. 108 do Código Eleitoral determinar que a eleição do candidato a cargos proporcionais era o resultado matemático do quociente eleitoral apurado entre partidos e coligações. Ademais, sustentava o PFL que a filiação partidária era condição constitucional de elegibilidade (art. 14, \$ $3^{\circ}$, (RFB), e esta condição traz aos eleitores a noção de

${ }^{151} \mathrm{MS}$ n. 23.405/GO, Rel. Min. Gilmar Mendes, j, 22.03.2004. 
vínculo entre o postulante e o partido, bem como à ideologia partidária ${ }^{152}$.

O TSE respondeu afirmativamente à primeira consulta ${ }^{153}$. Assim, apesar de não haver taxativamente no texto constitucional previsão de perda de mandato para o parlamentar infiel, o mandato em eleição proporcional pertence ao partido político, e não ao candidato eleito. Assim, ele só poderia trocar de partido na hipótese de apresentar uma justa causa.

A importância do partido político foi destacada pelo Min. Carlos Ayres Britto, uma vez que nas eleições majoritárias e proporcionais, o partido tem as seguintes competências: (i) selecionar seus filiados em convenção partidária; (ii) proceder a todos os registros de candidatura; (iii) coordenar todos os aspectos da propaganda eleitoral gratuita no rádio e na televisão; (iv) financiar campanhas por meio dos recursos amealhados no Fundo Partidário e também entre particulares. Por fim, foi relembrado o fato de que todos os candidatos serem obrigados a proceder à identificação eleitoral vinculada ao seu partido, por meio da numeração obrigatória para o voto na urna eletrônica.

Assim, o resultado proferido pelo TSE nas duas consultas citadas foi unânime, no sentido de que em qualquer cargo eletivo o mandato pertence ao partido, tanto nos cargos majoritários quanto nos proporcionais. o indivíduo que exerce mandato eletivo que quiser mudar de

152 Cf. REIS, Daniel Gustavo Falcão Pimentel dos. Financiamento da política no Brasil. Dissertação de Mestrado defendida na Faculdade de Direito da Universidade de São Paulo, 2010, p. 41.

${ }^{153} \mathrm{Cta}$. n. 1.398/DF, Rel. Min. Asfor Rocha, j. 27.03.2007. 
agremiação correria o risco de perder seu mandato, a não ser que apresentasse justificativa para sua troca.

Diante desta decisão, três partidos de oposição ao Presidente da República Luiz Inácio Lula da Silva (PT) acionaram o presidente da Câmara requerendo a cassação de parlamentares que saíram de suas bases e migraram para partidos de apoio à base governamental ${ }^{154}$. Com o indeferimento do requerimento, impetraram mandados de segurança no STF visando à concretização de seu direito líquido e certo, uma vez que, segundo O TSE, eram os legítimos detentores dos mandatos parlamentares em questão.

O STF decidiu conjuntamente os três mandados de segurança ${ }^{155}$. Por maioria de votos, o supremo decidiu por avalizar o posicionamento do TSE. Sua jurisprudência anterior, aqui já destacada, foi diametralmente modificada.

Pode-se classificar, na visão de Bradley Canon, que essa decisão do STF é altamente ativista. Canon adverte que a estabilidade interpretativa é um dos principais fatores para verificar se uma decisão pode ser classificada como ativista. Nesse caso, a mudança radical no posicionamento histórico do STF sobre a fidelidade partidária recai na segunda dimensão trazida por Canon, qual seja: alterações de decisões e doutrinas pretéritas.

\footnotetext{
154 Os partidos foram O PPS - Partido Popular Socialista, O DEM Democratas e O PSDB - Partido da Social Democracia Brasileira.

${ }^{155}$ MS n. 26.602/DF, Rel. Min. Eros Grau, j. 04.10.2007, impetrado pelo PPS; MS n. 26.603/DF, Rel. Min. Celso de Mello, j. 04.10.2007, impetrado pelo PSDB; MS n. 26.604/DF, Rel. Min. Cármen Lúcia, j. 04.10.2007, impetrado pelo DEM.
} 
O voto do Ministro Cezar Peluso resume com o posicionamento dos Ministros favoráveis à manutenção da decisão do TSE em sede de Consulta. O Ministro Peluso defendeu que o pertencimento do mandato político ao partido se deve, sobretudo, ao disposto no art. 45 da Constituição ${ }^{156}$.

Assim sendo, o sistema proporcional caracteriza-se, sobretudo, pelo fato de haver "preeminência radical dos partidos políticos sobre a pessoa dos candidatos 157 ". Essa preeminência existente no sistema proporcional se dá, principalmente, pelo fato de a ocupação das vagas ocorrer "mediante uso de quocientes eleitoral e partidário" ao partido ou coligação, "e não à pessoa que sob sua bandeira tenha concorrido e sido eleita".

Merece destaque este argumento. Realmente, o sistema proporcional à brasileira objetiva a valorização do voto na legenda. Desse modo, o eleitor, em tese, escolheria a melhor proposta político-partidária, e não um candidato qualquer. Na sistemática normativa brasileira, há, certamente, vínculo entre o nome do candidato e a sigla partidária.

A prática, entretanto, nos traz outro quadro. O sistema brasileiro proporcional de lista aberta faz com que o eleitor, na maior parte das vezes, vote no candidato. O fato de as campanhas eleitorais para cargos proporcionais serem individualizadas e a sistemática normativa fazem com que o maior adversário de um postulante a cargo proporcional seja um colega de partido, já que a

\footnotetext{
156 "Art. 45. A Câmara dos Deputados compõe-se de representantes do povo, eleitos, pelo sistema proporcional, em cada Estado, em cada Território e no Distrito Federal." (grifo nosso).

${ }^{157} \mathrm{MS}$ n. 26.602/DF, Rel. Min. Eros Grau, j. 04.10.2007.
} 
lista aberta "incentiva fortemente 0 indivíduo nas campanhas, especialmente porque o prestígio e o poder de um candidato são robustamente fortalecidos por um total de $\operatorname{votos}^{158 \prime \prime}$.

Como consequência da decisão do STF em sede de mandado de segurança, o Min. Celso de Mello sugeriu que a questão retornasse ao TSE para, em sede de resolução, fosse editada norma que regulasse o procedimento da possível perda de mandato por infidelidade partidária ${ }^{159}$, conforme trecho a seguir:

"Nada impedirá que o E. Tribunal Superior Eleitoral, à semelhança do que se registrou em precedente firmado no caso Mira Estrela/SP (RE 197.917-SP) formule e edite resolução destinada a regulamentar o procedimento (materialmente) administrativo de justificação em referência, instaurável perante órgão competente da própria Justiça Eleitoral, em ordem a estruturar, de modo formal, as fases rituais desse mesmo procedimento ${ }^{160,}$.

158 GERÔNIMO, Gislene Donizetti. "Fidelidade partidária". In: CAGGIANO, Monica Herman Salem; LEMBO, Cláudio (coord.). O voto nas Américas. Barueri: Manole, 2008, p. 130. No mesmo sentido, Luís Virgílio Afonso da Silva afirma que "em suma, é difícil, no Brasil, falar-se em política partidária, pois as campanhas são preponderantemente individuais". O resultado disso, para o autor, é o fato de o partido político ser "somente um veículo para que alguns políticos possam se eleger, independente de posições ideológicas e programas partidários". Sistemas eleitorais: tipos, efeitos jurídicopolíticos e aplicação ao caso brasileiro. São Paulo: Malheiros, 1999, p. 161 .

159 A decisão do STF em estabelecer competência ao TSE de regulamentar sobre o tema não foi, no nosso entender, a correta. Cabe ao Congresso Nacional, conforme arts. $2^{\circ}$ e 48 da CRFB, produzir leis. O STF sequer deu a oportunidade de o Parlamento se posicionar a respeito da nova interpretação do Judiciário sobre a fidelidade partidária. Ademais, relembra bem Angela Cristina Pelicioli que, na prática, o STF atuou sim como legislador positivo ao julgar os mandados de segurança e, consequentemente, determinar ao TSE a edição de Resolução regulamento - procedimento administrativo de eventual infidelidade partidária. Pelicioli sustenta seu argumento afirmando que nos mandados de segurança haveria, em tese, somente irradiação de efeitos inter partes. Ao remeter ao TSE a questão, os efeitos foram estendidos "a todos os partidos políticos e aos parlamentares eleitos sob uma determinada legenda e que tenham mudado de partido após as eleições, em razão da resolução do TSE". "O Supremo Tribunal Federal como legislador positivo: o caso da fidelidade partidária". In: Boletim de Direito Administrativo, ano XXIV, n. 11, nov. 2008, p. 1273.

${ }^{160}$ MS n. 26.603/DF, Rel. Min. Celso de Mello, j. 04.10.2007. 
A mudança trazida à baila pelo STF no tema da fidelidade partidária modificou todas as bases conceituais do tópico. Monica Herman Salem Caggiano, com o costumeiro brilhantismo, resumiu o "choque" trazido pelo julgamento do STF, em sede de mandado de segurança, confirmar a nova interpretação do STF:

"[O julgamento do STF inovou] quanto à tradicional postura que, rigidamente, mantinha entendimento preordenado a preservar: (a) a autonomia do partido em matéria de disciplina partidária, proclamando que este tema não poderia ser examinado em sede eleitoral, por versar questão interna corporis de partido político, um ente de direito privado; (b) o mandato parlamentar, em razão de sua própria natureza: livre; (c) a proporcionalidade na composição das Mesas Diretoras dos Legislativos, nas hipóteses de troca de partido, determinando a perda do cargo, nunca, porém do mandato; (d) a ideia da devolução da cadeira parlamentar ao partido, apenas na hipótese de morte ou renúncia de parlamentar infiel ${ }^{161 "}$.

Assim, O TSE editou a Resolução n. 22.610, de 25 de outubro de 2007. Esta resolução dispunha sobre o procedimento de dois pedidos, quais sejam: (i) Procedimento Administrativo de Decretação da Perda de Cargo Eletivo por Desfiliação Partidária sem Justa Causa; e (ii) Procedimento Administrativo de Justificação de Abandono de Sigla.

O primeiro deles tem como objetivo a decretação da perda de mandato. Assim, são legítimos para apresentarem referido procedimento à Justiça Eleitoral o partido detentor do mandato, o suplente e, por fim, o Ministério Público. Já ó segundo procedimento tem como legítimo requerente o político que mudou de partido, que visará a justificar os motivos de sua troca partidária.

${ }^{161}$ CAGGIANO, Monica Herman Salem. "A fenomenologia dos trânsfugas no cenário político-eleitoral brasileiro". In: CAGGIANO, Monica Herman Salem; LEMBO, Cláudio (coord.). O voto nas Américas. Barueri: Manole, 2008, p. 237. 
A Resolução em exame também previu as hipóteses de justa causa para a migração partidária. São eles: (i) incorporação ou fusão do partido; (ii) criação de um novo partido político; (iii) mudança substancial ou desvio reiterado do programa partidário; (iv) grave discriminação pessoal.

Referida resolução causou bastante polêmica nos meios político e acadêmico. Thales Tácito Pontes Luz de Pádua Cerqueira e Camila Medeiros de Albuquerque Pontes Luz de Pádua Cerqueira, por exemplo, creem que a Resolução está eivada de inconstitucionalidades, in verbis:

"Assim, o STF, conforme visto no julgamento do Mandado de Segurança 26603/2007, acabou, data vênia, por criar, um 'procedimento inexistente numa Justiça incompetente', ou seja, criou um procedimento denominado 'administrativo-eleitoral', quando na realidade é instrumento 'cível eleitoral', legislando sobre eleitoral e processo civil, matérias afetas à União $(\mathrm{CF} / 88$, art. 22, I) e, ainda, estipulou que a Justiça Eleitoral, e não a Comum (como sempre ocorreu no caso de perda de mandato após extrapolado o prazo de 15 dias da diplomação) fosse a competente para o caso concreto ${ }^{162, "}$.

$\mathrm{Na}$ mesma toada, Clèmerson Merlin Clève ensina que o exercício do mandato político no Brasil decorre da Constituição. Desse modo, a "autonomia do representante (...) vai sujeitar-se, em princípio, apenas aos ditames de sua consciência". Logicamente, segundo Clève, os partidos devem valer-se do princípio da fidelidade partidária, porém de "maneira moderada"63".

162 CERQUeirA, Thales Tácito Pontes Luz de Pádua; CERQUEIRA, Camila Medeiros de Albuquerque Pontes Luz de Pádua. Fidelidade partidária \& perda de mandato no Brasil: temas complexos. São Paulo: Premier Máxima, 2008, p. 85.

163 Clèmerson Clève completa o pensamento ao dizer que "a utilização desmedida do instituto [fidelidade partidária] fere a Constituição compreendida sistematicamente (...) não pode o instituto da fidelidade servir de amparo à agressão aos direitos fundamentais do parlamentar, especialmente a liberdade de consciência. Em determinadas circunstâncias, a liberdade de consciência pode e deve autorizar, a despeito da eleição de diretriz partidária, a abstenção do 
Já Ricardo Lewandowski, por exemplo, defendeu em artigo a decisão proferida pelo STF. Para o Ministro do Supremo, a fidelidade partidária nos moldes dos julgamentos proferidos pelo STF e pelo TSE garante à representação popular um "mínimo de autenticidade (...), de tal modo que entre eles [eleitores e candidatos] se estabeleça um liame em torno de valores que transcendam os aspectos meramente contingentes do cotidiano da política ${ }^{164 \prime \prime}$.

Ao nosso ver, é necessário fazer um contraponto às decisões do STF e do TSE no tema. A argumentação vencedora, no que tange à fidelidade partidária nos cargos proporcionais, faz bastante sentido. Afinal, a grande maioria dos postulantes aos cargos de vereador, deputado distrital, deputado estadual e deputado federal são eleitos graças ao mecanismo normativo previsto no Código Eleitoral dos quocientes partidário e eleitoral. O monopólio constitucional das candidaturas reforça o argumento. No entanto, não nos curvamos às decisões mais recentes do STF e do TSE no tópico pelo fato de não haver previsão constitucional e mesmo legal de punição àqueles que trocam de partido durante o mandato.

No campo majoritário, esta contradição fica bastante evidente. Um exemplo prático demonstra esta tese: se o Presidente da República é eleito pelo Partido $A B C$ e seu Vice-Presidente pelo Partido DEF, em chapa coligada, mas resolve sair de seu partido no meio do

parlamentar. Não é possível, afinal, que não se dê ao representante eleito sequer o direito de esquivar-se, por motivo de foro íntimo, dever de consciência ou convicção política, religiosa ou filosófica, de votar de acordo com a ordem recebida". Fidelidade partidária: estudo de caso. Curitiba: Juruá, 1. ed., 8. tir. 2008, p. 30.

164 LEWANDOWSKI, Ricardo. "Fidelidade partidária". In: Revista do Advogado, ano XXX, n. 109, agosto de 2010, p. 8-9. 
mandato para o partido XYZ, ele tem razoáveis chances de perder o mandato, uma vez que, por decisão do TSE confirmada pelo STF, os mandatos eletivos pertencem aos partidos. Assim, seguindo a lógica, o mandato presidencial pertence à agremiação ABC. No entanto, se o Presidente realmente perder seu mandato, quem assume, ante norma expressa da Constituição, é o Vice-Presidente filiado a partido diferente do que elegeu o Presidente. Mas, afinal, o mandato é do partido $\mathrm{ABC}$ ou não ${ }^{165}$ ?

Além disso, a decisão do STF em estabelecer competência ao TSE de regulamentar sobre o tema não foi, no nosso entender, a correta. Cabe ao Congresso Nacional, conforme arts. $2^{\circ}$ e 48 da CRFB, produzir leis. 0 STF sequer deu a oportunidade de o Parlamento se posicionar a respeito da nova interpretação do Judiciário sobre a fidelidade partidária.

Ademais, relembra bem Angela Cristina Pelicioli que, na prática, O STF atuou sim como legislador positivo ao julgar os mandados de segurança e, consequentemente, determinar ao TSE a edição de Resolução regulamento o procedimento administrativo de eventual infidelidade partidária.

Pelicioli sustenta seu argumento afirmando que nos mandados de segurança haveria, em tese, somente irradiação de efeitos inter partes. Ao remeter ao TSE a questão, os efeitos foram estendidos "a todos os partidos políticos e aos parlamentares eleitos sob uma

165 Corrobora com esta opinião Luciana Lóssio, que entende ser impossível aplicar a regra da fidelidade partidária para os cargos majoritários. "Infidelidade partidária para os cargos majoritários análise de um caso concreto". In: Revista Brasileira de Direito Eleitoral, ano 2, n. 3, jul. 2010. 
determinada legenda e que tenham mudado de partido após as eleições, em razão da resolução do TSE ${ }^{166 "}$.

A decisão do STF de enviar a questão da fidelidade partidária novamente ao TSE para que a Corte Eleitoral regulamente a questão claramente incide na sexta dimensão trazida por Bradley Canon e já estudada no Capítulo 2 supra. O STF desprezou completamente a possibilidade de o Congresso tratar sobre o tema. A Constituição determina que cabe ao Congresso Nacional legislar sobre direito eleitoral (arts. 22, I, c/c art. 48, caput, CRFB). O STF não concedeu qualquer prazo para os parlamentares discutirem e formularem a legislação pertinente à nova interpretação do Supremo no tema. No momento em que delegou essa tarefa ao Tribunal Superior Eleitoral, o Supremo desprezou, no ensinamento de Canon, as considerações que o órgão detentor da competência para tanto teria a fazer sobre o tema.

Ao ser editada pelo TSE, a Resolução n. 22.610/2007 foi alvo de uma ação direta de inconstitucionalidade, ajuizada pelo PSC - Partido Social Cristão.

A petição inicial da ADI n. 3.999/DF continha diversos argumentos visando à declaração da inconstitucionalidade da Resolução do TSE que tratava do procedimento administrativo da perda de mandato do infiel. A primeira dela cingia-se contra o art. $2^{\circ}$ da Resolução, uma vez que o art. 121 da Constituição ${ }^{167}$ previa que cabe à

166 PELICIOLI, Angela Cristina. "O Supremo Tribunal Federal como legislador positivo: o caso da fidelidade partidária". In: Boletim de Direito Administrativo, ano XXIV, n. 11, nov. 2008, p. 1273.

167 "Art. 121. Lei complementar disporá sobre a organização e competência dos tribunais, dos juízes de direito e das juntas eleitorais". 
lei complementar dispor sobre as competências dos órgãos da Justiça Eleitoral.

A segunda alegação consistia no fato de o TSE ter usurpado a competência do Legislativo e do Executivo para dispor sobre matéria eleitoral (arts. 22, inciso I; 48 e 84, IV, da Constituição), uma vez que o art. $1^{\circ}$ da Resolução disciplinava a perda do mandato de maneira inovadora.

Os mesmos artigos citados do texto constitucional foram violados, na visão do PSC, pelo fato de a Resolução estabelecer normas de caráter processual, já que a norma editada pelo TSE previa: (i) forma da petição inicial e das provas (art. $3^{\circ}$ ); (ii) prazo para resposta e as consequências de eventual revelia (art. $3^{\circ}$ ); (iii) os requisitos e direitos da defesa (art. 50); (iv) o julgamento antecipado da lide (art. $6^{\circ}$ ); e, por fim, o ônus da prova (art. $\left.7^{\circ}\right)$.

Finalmente, a terceira alegação do partido versava sobre a criação de atribuição ao Ministério Público por meio de Resolução. A omissão do partido político no Procedimento Administrativo de Decretação da Perda de Cargo Eletivo por Desfiliação Partidária sem Justa Causa abria a possibilidade, segundo $\circ \$ 2^{\circ}$ do art. $1^{\circ}$ da Resolução n. 22.610/2007, de o Parquet ou terceiro interessado ingressar na Justiça Eleitoral com o objetivo de cassar o mandato do político infiel. Assim sendo, tal atribuição violaria os arts. 128, $\$ 5^{\circ} ;$ e 129, IX, da Constituição ${ }^{168}$.

\footnotetext{
${ }^{168}$ No mesmo sentido, a Procuradoria-Geral da República, órgão máximo do Ministério Público da União, manifestou-se na ADI n. 4.086/DF, ação esta julgada conjuntamente com a ADI n. 3.999/DF. Luciana Lóssio também vê inconstitucionalidade na legitimidade do Ministério Público
} 
Mesmo tendo se posicionado contra a ideia de que a fidelidade partidária está prevista na sistemática constitucional brasileira, o Min. Joaquim Barbosa, relator da ADI em comento, avocou o princípio da colegialidade para, mesmo discordando, reconhecer que o STF adotou a tese de que há a obrigação de fidelidade partidária por parte dos detentores de mandato eletivo.

Assim sendo, e diante do fato de que sem a Resolução do TSE impugnada, a decisão do STF nos mandados de segurança não teria eficácia alguma, o Min. Barbosa, ressaltando que se tratava de um "quadro excepcional, de carência de meio para garantia de um direito constitucional, marcado pela transitoriedade 169 ", julgou constitucional a Resoluçãon. 22.610/2007170.

Por fim, realçou o Ministro Relator que a competência para legislar sobre o assunto era do Congresso Nacional. Por se tratar de uma situação extraordinária, marcada "pela necessidade de proteção de um direito que emana da própria Constituição", a atividade normativa do TSE deveria receber "amparo da extraordinária circunstância de o Supremo Tribunal Federal ter reconhecido a fidelidade partidária como requisito para permanência em cargo eletivo

Eleitoral, ao anotar que "se o mandato pertence ao partido, e este não quis reavê-lo, não se pode transmudar essa legitimidade ativa ad causam para o Ministério Público Eleitoral". "Infidelidade partidária para os cargos majoritários - análise de um caso concreto". In: Revista Brasileira de Direito Eleitoral, ano 2, n. 3, jul. 2010.

${ }^{169} \mathrm{ADI}$. 3.999/DF. Rel. Min. Joaquim Barbosa, j. 12.11.2008.

170 Angela Cristina Pelicioli critica este posicionamento do STF, ao observa que "a deficiência do Poder Legislativo, por si só, não é argumento que se possa utilizar para definir a legitimidade democrática do Supremo Tribunal Federal como garantidor da Constituição, mas não deixa de ser um forte argumento a favor". "O Supremo Tribunal Federal como legislador positivo: O caso da fidelidade partidária". In: Boletim de Direito Administrativo, ano XXIV, n. 11, nov. 2008, p. 1266. 
e a ausência expressa de mecanismo destinado a assegurá$10^{171 \prime \prime}$.

O Ministro Marco Aurélio abriu a divergência trazendo à baila uma questão preliminar: a Resolução n. 22.610/2007 não poderia ser objeto de controle de constitucionalidade, por se tratar de mero regulamento. O então Presidente do STF, Min. Gilmar Mendes, ressaltou que o Supremo, ao conhecer da ADI em comento, estava "avançando na cognoscibilidade também de questões que antes não eram admissíveis em sede de ADI", Não convencido, o Ministro Marco Aurélio votou pelo não conhecimento da ação, opinião da qual foi voto vencido isoladamente.

Votaram pelo posicionamento do Relator os Ministros Menezes Direito, Cármen Lúcia ${ }^{172, ~ R i c a r d o ~}$ Lewandowski, Carlos Ayres Britto, Ellen Gracie, Cezar Peluso e Gilmar Mendes.

O Ministro Eros Grau inaugurou a divergência no julgamento de mérito. Grau reconheceu todas as alegações do PSC. Já no julgamento dos mandados de segurança, o Min. Eros Grau havia se posicionado contrariamente à decisão do TSE em sede de Consulta. Neste momento, coerentemente, julgou procedente os pedidos do PSC .

No mesmo sentido, o Ministro Marco Aurélio entendeu que por se tratar, na prática, de ato normativo que "adentrou o campo do direito substancial para

${ }^{171}$ ADI n. 3.999/DF. Rel. Min. Joaquim Barbosa, j. 12.11.2008.

172 A Ministra Cármen Lúcia também destacou, em seu voto, o fato de a Resolução n. 22.610 ter vindo à baila como instrumento que garantisse a efetividade do julgamento da questão da fidelidade partidária nos mandados de segurança citados. Para a Ministra, "em última análise", estava em jogo "a efetividade da própria Constituição". 
revelar situações concretas em que se teria o abandono do partido que capitaneou a eleição do candidato173", continua seu raciocínio ao afirmar que o TSE, na verdade, ao editar a Resolução ora impugnada, "acabou julgando implicitamente um mandado de injunção ante a lacuna legislativa, ante a inexistência de diploma que versasse todos os temas contidos na Resolução, ante a inércia do Congresso Nacional, e competente para julgar mandado de injunção, neste caso, é o Supremo e não o Tribunal Superior Eleitoral".

A decisão do STF de declarar constitucional a Resoluçãon. 22.610/2007 trouxe ao sistema político brasileiro duas importantes consequências. A primeira delas foi a nítida diminuição no número de trocas de parlamentares no Legislativo e no Executivo. Já a segunda não foi prevista pelo STF e pode levar à decisão para uma inefetividade prática.

De uma parte, é forçoso reconhecer que o advento da fidelidade partidária deu maior força aos partidos políticos, uma vez que

"podem, desde a eleição, manter praticamente inalterado o número de cadeiras nas Casas Legislativas, sabendo sua força na negociação parlamentar e também melhor se preparando para as eleições seguintes ${ }^{174,}$.

De outra parte, a possibilidade prevista na própria Resolução como justa causa para a troca de partido quando o político participar da criação de um novo partido serviu como "janela de escape" para políticos

\footnotetext{
${ }^{173}$ ADI n. 3.999/DF. Rel. Min. Joaquim Barbosa, j. 12.11.2008.

174 REIS, Daniel Gustavo Falcão Pimentel dos; MACEDO, Rafael Rocha de. "O partido político e as campanhas eleitorais brasileiras: sistema normativo, propostas de reforma legislativa e as recentes decisões do Supremo Tribunal Federal". In: CAGGIANO, Monica Herman Salem (org.). Comportamento eleitoral. Barueri, Manole, 2010, p. 187.
} 
insatisfeitos nos seus partidos de origem. A comparação cronológica demonstra essa situação.

Durante toda a primeira década do século XXI, conseguiram registro definitivo no TSE apenas dois novos partidos, quais sejam: O PRB - Partido Republicano Brasileiro e O PSOL - Partido Socialismo e Liberdade.

Desde 2011, porém, houve a criação de cinco novos partidos no já exacerbado sistema multipartidário brasileiro. São eles o PSD - Partido Social Democrático; PPL - Partido Pátria Livre; PEN - Partido Ecológico Nacional; PROS - Partido Republicano da Ordem Social e, por último, o SDD - Solidariedade ${ }^{175}$. Todas estas cinco novas agremiações aproveitaram a brecha da Resolução n. 22.610 e arregimentaram diversos congressistas e demais políticos famosos, prejudicando, principalmente, os partidos de oposição ao governo federal atual.

O exame da questão da fidelidade partidária serviu para demonstrar, mais uma vez, a importância do fenômeno do ativismo judicial na Justiça Eleitoral brasileira, especialmente por meio das competências regulamentar e consultiva previstas no art. 23 do Código Eleitoral.

O tema ora em debate evidenciou que o TSE vem exacerbando sua competência legal e constitucional, com o aval do STF. Neste caso, não havia qualquer irregularidade no fato de o Supremo Tribunal Federal corroborar com o posicionamento do TSE na perda de mandato

175 Não podemos ainda contar nesta lista com a Rede Sustentabilidade, liderado pela ex-senadora pelo Acre, Marina Silva. A Rede teve seu registro indeferido pelo TSE em outubro de 2013. Entretanto, a campanha pelo recolhimento de assinaturas continuou, sendo bastante possível novo pedido de registro em 2015. 
por infidelidade partidária. A crítica se volta a outra face da decisão: a escolha, por parte do STF, do TSE para legislar sobre a questão da fidelidade.

Causa estranhamento a escolha feita pela cúpula do Poder Judiciário. Ao ser provocado com três casos concretos diferentes, O STF proferiu julgamento concordando com o posicionamento exarado pelo TSE, mas, ao invés de definir que o Congresso legislasse sobre o assunto em um prazo razoável, preferiu o Supremo em diligenciar novamente a um órgão do próprio Judiciário as providências procedimentais, com vistas à eficácia da norma constitucional interpretada ${ }^{176}$. Ainda que esse órgão judiciário tenha, entre diversas competências, a de administrar e regulamentar o pleito eleitoral, a inovação normativa deveria ser determinada ao Congresso Nacional, órgão com legitimidade constitucional para tratar do tema (art. 48, caput, c/c art. 22, I, ambos da CRFB), e não ao órgão regulador ${ }^{177}$.

$$
\text { Este fato foi tão aberrante que, }
$$
confrontada em sua constitucionalidade, o próprio STF

\footnotetext{
176 A outra oportunidade em que o STF demandou providências ao TSE no sentido de garantir eficácia a seu julgamento foi estudada no item 2.5.2. supra.

177 Elival da Silva Ramos concorda com o posicionamento adotado neste trabalho, ao ponderar que "impor ao parlamentar eleito pelo sistema proporcional a perda de mandato em caso de desfiliação partidária configura um dos episódios mais característicos de ativismo judiciário de toda história daquela Excelsa corte [STF]". O autor completa seu ensinamento ao asseverar que "a atuação do Supremo Tribunal Federal para além dos limites que o sistema constitucional brasileiro impõe à função jurisdicional fica ainda mais nítida quando se examinam as consequências extraídas da tese principal da perda de mandato por desfiliação partidária. Se do princípio da representação proporcional, conjugado com o do monopólio partidário das candidaturas, decorre a perda do mandato por desfiliação, deveria ter o STF se limitado a constatar a ocorrência, determinando à Presidência da Câmara a convocação se suplentes filiados aos partidos que faziam jus às vagas que, dessa forma, tivessem sido abertas". Ativismo judicial: parâmetros dogmáticos. São Paulo: Saraiva, 2010, p. 249-253.
} 
admitiu que se tratava de uma excepcionalidade, caracterizada pela transitoriedade.

Esta, porém, não se confirmou: sete anos depois, continua a viger a Resolução n. 22.610/2007. Sem fixar prazo para que o Congresso debatesse e decidisse sobre o assunto, a inércia do Parlamento persiste. E O espírito da decisão do STF no que toca à fidelidade partidária está sendo diuturnamente violado por uma brecha prevista na própria Resolução.

\subsubsection{Conceito de quitação eleitoral (2008 e 2012)}

A última grande discussão judicial ocorrida no Brasil que envolveu questão de direito político-eleitoral e um novo conflito - mesmo que não declarado - entre o Congresso Nacional e o Poder Judiciário foi em torno do conceito de quitação eleitoral. O inciso VI do $\$ 1^{\circ}$ do art. 11 da Lei das Eleições ${ }^{178}$ prevê que 0 registro de candidatura deve ser solicitado pelo partido ou coligação acompanhado, dentre outros documentos, da certidão de quitação eleitoral. Nenhuma lei, entretanto, trouxe à tona o conceito de quitação eleitoral ou de sua certidão.

Assim sendo, coube ao Tribunal Superior Eleitoral, por meio do mecanismo já estudado no item 3.3, qual seja, as Resoluções regulamentares previstas no art.

\footnotetext{
178 "Art. 11. Os partidos e coligações solicitarão à Justiça Eleitoral - registro de seus candidatos até às dezenove horas do dia 5 de julho do ano em que se realizarem as eleições. $\$ 1^{\circ} O$ pedido de registro deve ser instruído com os seguintes documentos:

$(\ldots)$

VI - certidão de quitação eleitoral".
} 
23, IX, do Código Eleitoral, trazer à tona a regulamentação do conteúdo abarcado pela referida certidão.

A primeira interpretação que $O$ TSE apresentou do instituto surgiu em 2004, por meio da Resolução n. $21.823^{179}$. Nela, Corregedoria Regional Eleitoral de Minas Gerais consultou o Tribunal Superior a respeito da abrangência do instituto ora debatido.

O Ministro Relator destacou em seu voto que naquele momento o sistema de alistamento eleitoral dispunha somente de mecanismos aptos a registrar as seguintes irregularidades: (i) ausência do eleitor às eleições; (ii) não-atendimento pelo eleitor à convocação para auxiliar os trabalhos eleitorais; e (iii) não pagamento de multa de natureza criminal aplicada ${ }^{180}$. Ficava fora, portanto, qualquer outro tipo de penalidade aplicada pela Justiça Eleitoral.

Resumindo, para O TSE, a certidão de quitação eleitoral seria o documento previsto na Lei das Eleições que comprovaria no momento do registro da candidatura 0 fato de 0 candidato cumprir condição constitucional de elegibilidade, qual seja, o pleno

\footnotetext{
179 Resolução n. 21.823/2004. Processo Administrativo n. 19.205/DF. Rel. Min. Francisco Peçanha Martins. DJ 05.07.2004.

180 Alberto Rollo ensina maiores detalhes sobre a abrangência da certidão de quitação eleitoral: "Essa certidão significava que o candidato estava no gozo dos direitos políticos, não existindo sua suspensão por nenhuma causa, seja por condenação criminal, seja por condenação em ação de improbidade. Significava também o exercício do voto nas últimas três eleições, ou o pagamento de multa relativa a esses pleitos, ou a justificativa relativa ao não comparecimento. Significava ainda o trabalho como mesário se e quando convocado. Finalmente significava a inexistência de multas aplicadas com trânsito em julgado do processo, e não remitidas e, por fim, a apresentação de contas de campanha eleitoral em pleito anterior.". ROLLO, Alberto (org.). Eleições no direito brasileiro: atualizado com a Lei $\mathrm{n}^{\circ}$ 12.034/09. São Paulo: Atlas, 2010, p. 30.
} 
exercício dos direitos políticos, requisito este previsto no inciso II do parágrafo $\$ 3^{\circ}$ do art. 14 da $\mathrm{CRFB}^{181}$.

Diante disso, o Ministro Relator
enfatizou em seu voto qual era o verdadeiro sentido do
instituto na Lei das Eleições, conforme trecho a seguir:

"Dado o exposto, voto no sentido de fixar como núcleo essencial do conceito de quitação eleitoral a plenitude do gozo dos direitos políticos, o regular exercício do voto, salvo quando facultativo, o atendimento a convocações da Justiça Eleitoral para auxiliar os trabalhos relativos ao pleito e a inexistência de pendências referentes a multas aplicadas, em caráter definitivo, pela Justiça Eleitoral, com ressalva das anistias legais, admitindose, por aplicação analógica do art. 11 do Código Eleitoral, o pagamento, perante qualquer juízo eleitoral, dos débitos decorrentes de sanções pecuniárias de natureza administrativa impostas com base no Código Eleitoral e na Lei $n^{\circ}$ 9.504/97, ao qual deve preceder, nos casos envolvendo penalidades diversas da prevista para ausência às eleições, consulta ao juízo de origem sobre o quantum a ser exigido pelo devedor," ${ }^{, 182}$.

o Ministro Fernando Neves, em voto-vista, acrescentou o ponto que trouxe a polêmica que será aqui debatida. Ele entendeu, com a concordância unânime do Pleno do TSE, que a não apresentação de contas relativas a campanhas eleitorais também seria uma hipótese para o cidadão não obter a certidão de quitação eleitoral, conforme interpretação do art. 28 da Lei das Eleições.

Houve, posteriormente, agitação na Justiça Eleitoral nos julgamentos de casos concretos sobre o tema. No entanto, o TSE pacificou sua jurisprudência, ao determinar que a Resolução n. 21.823/2004 somente esclareceu o alcance do conceito de quitação eleitoral,

\footnotetext{
181 "Art. 14. A soberania popular será exercida pelo sufrágio universal e pelo voto direto e secreto, com valor igual para todos, e, nos termos da lei, mediante: 
previsto no art. 11, VI, da Lei das Eleições. A certidão de quitação eleitoral, nos moldes da referida Resolução, não tratava de nova hipótese de inelegibilidade, mas sim de uma condição legal de elegibilidade relativa ao pleno exercício dos direitos políticos, conforme previsão do art. 14, \$ $3^{\circ}$, inciso II, da Constituição. Nesse sentido, mesmo aqueles candidatos que em eleições anteriores apresentaram sua prestação de contas intempestivamente tiveram seus registros de candidatura rejeitados ${ }^{183}$.

Pode-se citar como verdadeiro leading case da questão o julgamento do Recurso Ordinário n. $1.108 / \mathrm{MA}^{184}$. A constitucionalidade da referida resolução foi confirmada, uma vez que não houve a criação de uma nova condição de elegibilidade, mas sim a simples delimitação do conceito de quitação eleitoral ${ }^{185}$.

A grande discórdia entre a Justiça Eleitoral e o Congresso Nacional no que tange à certidão de quitação eleitoral brotou, na verdade, durante a discussão das Resoluções que versariam sobre as eleições municipais de outubro de 2008.

\footnotetext{
183 AgR-RO n. 1.227/RS, Rel. Min. Gerardo Grossi, j. 29.09.2006. No mesmo sentido, REspe n. 26.348/MA, Rel. Min. Cezar Peluso, j. 21.09.2006; RO n. 1.055/SE, Rel. Min. José Delgado, j. 14.09.2006.

${ }_{184}$ RO n. 1.108/MA, Rel. Min. Marcelo Ribeiro, j. 27.09.2006. No mesmo sentido, ED-AgR-RO n. 1.269/SP, Rel. Min. Gerardo Grossi, j. 05.10 .2006 .

185 No mesmo sentido, pode-se citar o voto do Min. Rel. Gerardo Grossi no AgRg-RO n. 1.269/SP: "Ora, como é cediço, a quitação eleitoral insere-se no âmbito da condição de elegibilidade relativa ao pleno exercício dos direitos políticos, exigida pelo art. 14, $\$ 3^{\circ}$, inciso II, da Constituição Federal. Em outras palavras: a plenitude do exercício dos direitos políticos pressupõe, necessariamente, a quitação do eleitor perante a Justiça Eleitoral. Assim, basta que se atente para a natureza jurídica do instituto da quitação eleitoral para que seja afastada a alegação de inconstitucionalidade pois, como demonstrado, não se trata de nova causa de inelegibilidade, mas tãosomente corolário da condição de elegibilidade relativa ao pleno exercício dos direitos políticos". AgRg-RO n. 1.269/SP, Rel. Mi n. Gerardo Grossi, j. 26.09.2006.
} 
A Resolução n. $22.715^{186}$, que tratava da arrecadação e aplicação de recursos por candidatos e comitês financeiros e prestação de contas nas eleições municipais de 2008, previa, no parágrafo $3^{\circ}$ do art. $41^{187}$, que a desaprovação da prestação de contas apresentada pelo candidato implicaria no impedimento na obtenção da certidão de quitação eleitoral durante o curso do mandato ao qual concorreu.

Na prática, por se tratar de eleição municipal, qualquer candidato a prefeito, vice-prefeito ou vereador - eleito ou não - que tivesse sua prestação de contas rejeitada pela Justiça Eleitoral não obteria o registro de candidatura nas eleições gerais de 2010 e também nas eleições municipais de 2012, uma vez que ele perdeu uma condição constitucional de elegibilidade.

O TSE, em seu exercício jurisdicional, confirmou decisões anteriores no que diz respeito à não obtenção da certidão de quitação eleitoral para candidatos que não apresentaram a respectiva prestação de contas ${ }^{188}$. No mesmo sentido, a apresentação extemporânea da prestação de

\footnotetext{
186 Resolução n. 22.715/2008. Instrução n. 118/DF. Rel. Min. Ari Pargendler. DJ 10.03.2008.

187 "Art. 41. A decisão que julgar as contas dos candidatos eleitos será publicada em até 8 dias antes da diplomação (Lei nº 9.504/97, art. $30, \$ 1^{\circ}$ ).

$\$ 1^{\circ}$ Desaprovadas as contas, o juízo eleitoral remeterá cópia de todo - processo ao Ministério Público Eleitoral para os fins previstos no art. 22 da Lei Complementar $n^{\circ}$ 64/90 (Lei $n^{\circ}$ 9.504/97, art. 22, \$ 4\%). $\$ 2^{\circ} \mathrm{Na}$ hipótese de aplicação irregular de recursos do Fundo Partidário ou da ausência de sua comprovação, a decisão que julgar as contas determinará a sua devolução ao Erário.

$\$ 3^{\circ}$ Sem prejuízo do disposto no $\$ 1^{\circ}$, a decisão que desaprovar as contas de candidato implicará o impedimento de obter a certidão de quitação eleitoral durante o curso do mandato ao qual concorreu."

188 AgR-REspe n. 374.485/MG, Rel. Min. Marcelo Ribeiro, j. 010.09.2010. No mesmo sentido, ED-REspe n. 456.317/CE, Rel. Min. Marcelo Ribeiro, j. 03.11 .2010 .
} 
contas teve como consequência a não obtenção da certidão ${ }^{189}$. Essas decisões, portanto, seguiram a ideia trazida pela Resolução n. 21.823/2004.

A polêmica, de fato, surgiu com a novidade disposta na Resoluçãon. 22.715/2008, qual seja: não bastava mais a singela apresentação da prestação de contas. Elas teriam que ser aprovadas pela Justiça Eleitoral para que o candidato obtivesse sucesso em seu registro de candidatura.

Luciano Caleiro Pimenta Júnior resume a polêmica trazida pela nova interpretação: "O TSE exorbitou ou não de sua função normativa, prevista no art. $1^{\circ}$, parágrafo único, do Código Eleitoral, ao dispor sobre a consequência da desaprovação de contas de campanha do candidato ao cargo eletivo? ${ }^{190 \prime \prime}$.

No transcorrer de 2008, primeiramente, o TSE negou a aplicação do $\$ 3^{\circ}$ do art. 41 da Resolução n. $22.715 / 2008$ para todos os feitos anteriores a 2008. No Recurso Especial Eleitoral n. 29.020/GO ${ }^{191}$, por unanimidade, - Tribunal Superior Eleitoral decidiu aplicar o princípio da irretroatividade, no sentido de que referido dispositivo somente seria aplicado a partir da prestação de contas das eleições municipais de 2008. Pelo princípio da segurança jurídica, "a situação relativa à prestação de contas de campanha de candidato que concorreu ao pleito de 2004 deve

\footnotetext{
189 AgR-REspe n. 33.966/MA, Rel. Min. Joaquim Barbosa, j. 16.12.2008. No mesmo sentido, RO n. 1.121/RS, Rel. Min. José Delgado, j. 14.09 .2006 .

190 PIMENTA JÚNIOR, Luciano Caleiro. "Desaprovação de contas de campanha e a 'perda' do cargo eletivo". In: Revista de doutrina e jurisprudência - Tribunal Regional Eleitoral de Minas Gerais, n. 20, 2010, p. 57.

${ }^{191}$ REspe n. 29.020/GO, Rel. Min. Ari Pargendler, j. 02.09.2008.
} 
ser apreciada sob a ótica da Res.-TSE n²1.609/2004192". Na prática, a incidência do referido dispositivo só repercutiria nas eleições gerais de 2010.

No mais, O TSE assentou sua jurisprudência no sentido de que a sentença que rejeitasse a prestação de contas por intempestividade, por si só, não incidiria na não expedição da certidão de quitação eleitoral ao candidato, uma vez que "a desaprovação das contas referida na Res-TSE $n^{\circ} 22.715$ pressupõe efetivo julgamento ou apreciação de mérito das contas, ou seja, não abarca hipótese em que tenha havido mera constatação de intempestividade $193 "$.

Por fim, em 2008, O TSE confirmou a constitucionalidade do $\$ 3^{\circ}$ do art. 41 da Resolução $n$. 22.715, já que "a própria redação do artigo 14, \$ 30, da Constituição remete à lei a definição dos conceitos das condições de elegibilidade nele arrolados, entre os quais, aquele disposto no inciso II, referente ao pleno gozo dos

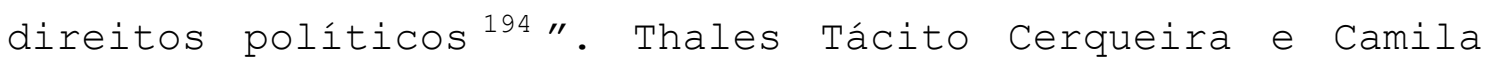
Albuquerque Cerqueira corroboram com essa análise, ao comentarem que a certidão de quitação eleitoral "é espécie do gênero 'condição de elegibilidade' e, como tal, por não ser inelegibilidade (..) pode ser criada por lei ordinária ou inclusive por resoluções do TSE ${ }^{195196 " .}$

\footnotetext{
192 REspe n. 29.020/GO, Rel. Min. Ari Pargendler, j. 02.09.2008, Voto do Min. Marcelo Ribeiro.

193 AgR-REspe n. 30.224/PA, Rel. Min. Eliana Calmon, j. 21.10.2008.

194 AgR-REspe n. 31.269/PB, Rel. Min. Felix Fischer, j. 13.10.2008.

195 CERQUEIRA, Thales Tácito; CERQUEIRA, Camila Albuquerque. Reformas eleitorais comentadas - Lei n. 12.034/2009 (minirreforma política e eleitoral) e LC n. 135/2010 (ficha limpa). São Paulo: Saraiva, 2010, p. 92.

196 Discorda desse posicionamento o doutrinador Alberto Rollo. Ele afirma que a previsão normativa de não obtenção da certidão de quitação eleitoral pelo candidato que teve sua prestação de contas de campanha não aprovada na eleição anterior criou nova hipótese de inelegibilidade, o que, segundo a Constituição (art. 14, \$ 9), só
} 


\begin{abstract}
A conceituação das condições de elegibilidade e de inelegibilidade causa discussões no âmbito doutrinário e jurisprudencial. Adriano Soares da Costa, no entanto, explica com maestria a diferenciação entre os dois conceitos. As condições de elegibilidade são "verdadeiras condições de registrabilidade, ou seja, pressupostos ao registro de candidatura ${ }^{197 ", ~ s e n d o ~ e l a s ~}$ exigências contidas na Constituição ou na legislação ordinária para que o candidato proceda ao registro de sua postulação.
\end{abstract}

Já a inelegibilidade, segundo Costa, "é o estado jurídico de ausência ou perda de elegibilidade", ou seja, "é o estado jurídico negativo de quem não possui tal direito subjetivo - seja porque nunca o teve, seja porque o perdeu ${ }^{198 \prime \prime}$.

Todas essas decisões do TSE, no sentido de trazer maior rigor ao procedimento de prestação de contas de campanha eleitoral aos candidatos por meio do alargamento da abrangência do conceito de quitação eleitoral, foram defendidas por doutrinadores. Adriano Denardi Júnior enfatiza que a certidão de quitação eleitoral carrega uma peculiaridade: "apenas o TSE está apto a dizer o que é quitação eleitoral e quem a possui. (...) A abrangência do conceito de quitação está

pode ser feito por meio de lei complementar. RoLLO, Alberto (org.). Eleições no direito brasileiro: atualizado com a Lei n 12.034/09. São Paulo: Atlas, 2010, p. 31.

197 CostA, Adriano Soares da. Instituições de direito eleitoral. Belo Horizonte: Del Rey, $6^{a}$ ed. rev., ampl. e atual., 2006, p. 91.

198 CostA, Adriano Soares da. Instituições de direito eleitoral. Belo Horizonte: Del Rey, 6a ed. rev., ampl. e atual., 2006, p. 217. 
diretamente ligada à evolução da jurisprudência daquela corte Superior ${ }^{199 \prime \prime}$.

Após essa novidade trazida pela Resolução n. 22.715/2008 no que tange à certidão de quitação eleitoral, o Congresso Nacional aprovou e o Presidente da República sancionou a chamada "minirreforma eleitoral". A Lei n. 12.034, de 29 de setembro de 2009, contém diversas modificações à Lei dos Partidos Políticos e à Lei das Eleições.

Quanto à certidão de quitação eleitoral, a minirreforma eleitoral especificou detalhadamente a abrangência da certidão de quitação eleitoral ao incluir o $\$ 7^{\circ}$ ao art. 11 da Lei das Eleições, in verbis:

"§ $7^{\circ}$ A certidão de quitação eleitoral abrangerá exclusivamente a plenitude do gozo dos direitos políticos, o regular exercício do voto, o atendimento a convocações da Justiça Eleitoral para auxiliar os trabalhos relativos ao pleito, a inexistência de multas aplicadas, em caráter definitivo, pela Justiça Eleitoral e não remitidas, e a apresentação de contas de campanha eleitoral".

Assim, desde então referida certidão serviria somente para afirmar que o candidato: (i) estava ou não no gozo dos direitos políticos, podendo, portanto, votar e ser votado regularmente; (ii) havia ou não atendido às convocações da Justiça Eleitoral para o auxílio nos trabalhos que envolvam a realização das eleições; (iii) tinha ou não condenação, em caráter definitivo, pela Justiça Eleitoral, ao pagamento de multas ${ }^{200}$; (iv) havia

\footnotetext{
199 DENARDI JÚNIOR, Adriano. "Prestação de contas de campanha, quitação eleitoral e inelegibilidade". In: Revista de doutrina e jurisprudência - Tribunal Regional Eleitoral de Minas Gerais, n. 18, 2008, p. 16.

$200 \bigcirc \$ 8^{\circ}$ do art. 11 da Lei das Eleições, também incluído pela Minirreforma eleitoral (Lei n. 12.034/2009), dispôs sobre hipóteses de quitação de multas eleitorais no caso de parcelamento da dívida, atenuando ainda mais a então vigente interpretação do TSE no tema. Ademais, $\circ \$ 9^{\circ}$, também incluído pela minirreforma, determina à Justiça Eleitoral a publicação de relação de todos os devedores de multa eleitoral que embase possível expedição de certidão positiva de
} 
apresentado ou não sua prestação de contas em campanhas eleitorais.

O termo "exclusivamente" do início do texto do $\$ 7^{\circ}$ do art. 11 da Lei das Eleições deixou nítido - fato de que não poderia haver interpretação jurisprudencial no sentido de acrescer novas exigências aos candidatos para a obtenção da certidão de quitação eleitoral ${ }^{201}$. Thales Tácito Cerqueira e Camila Albuquerque Cerqueira concordam com esta análise, ao asseverarem que "o legislador foi claro ao determinar que, doravante, o TSE não pode mais criar modalidades de quitação eleitoral não previstas pelo Poder Legislativo ${ }^{202 " .}$

Consequentemente, a Resolução n. 23.221, de 2 de março de $2010^{203}$, que dispunha sobre a escolha e registro de candidatos nas eleições de outubro daquele ano, não continha qualquer disposição diferente da adotada na minirreforma eleitoral no que tange à certidão de quitação eleitoral (art. 26, \$ $4^{\circ}$ ).

A Minirreforma Eleitoral de 2009 acarretou em clara discordância no Pleno do TSE no que toca à certidão de quitação eleitoral, mesmo após a edição da Resolução n. 23.221. Primeiramente, o TSE teve que decidir sobre a questão em sede de processo administrativo. O então

quitação eleitoral um mês antes do prazo final para o registro de candidaturas com o intuito de informá-los da dívida a tempo de quitála.

201 No mesmo sentido, Walber de Moura Agra e Francisco Queiroz Cavalcanti entendem que se trata de "hipótese taxativa, sem que as instâncias judiciárias possam requerer outros documentos ausentes do rol acima destacado". Comentários à nova lei eleitoral: lei n. 12.034, de 29 de setembro de 2009. Rio de Janeiro: Forense, 2009, p. 29.

202 CERQUEIRA, Thales Tácito; CERQUEIRA, Camila Albuquerque. Reformas eleitorais comentadas - Lei n. 12.034/2009 (minirreforma política e eleitoral) e LC n. 135/2010 (ficha limpa). São Paulo: Saraiva, 2010, p. 92 .

203 Instrução n. 11-74.2010.6.00.0000, Resolução n. 23.221, de 02.03 .2006$, Rel. Min. Arnaldo Versiani. 
Corregedor-Geral da Justiça Eleitoral, Min. Felix Fischer, encaminhou ao relator da Resolução que tratava da escolha e do registro de candidatos na eleição daquele ano, Min. Arnaldo Versiani, informação na qual noticiava reiterados questionamentos dos tribunais regionais eleitorais "pertinentes à situação eleitoral de candidatos que tiveram contas de campanha desaprovadas em 2008 em face da nova abrangência conferida à quitação eleitoral pelo congresso Nacional [Lei n. 12.034/2009 - Minirreforma Eleitoral]204".

O Ministro Arnaldo Versiani ressaltou em seu voto que a nova lei adotou nova abrangência à certidão de quitação eleitoral no que tange à apresentação de prestação de contas de campanha eleitoral. A nova abrangência legal, portanto, era absolutamente silente quanto à desaprovação de contas de campanha resultar na não obtenção da certidão. Assim sendo, para o Ministro Versiani, a Minirreforma Eleitoral "passou a versar exaustivamente sobre o tema, motivo pelo qual as eventuais desaprovações das eleições de 2008 não podem ser consideradas como óbice à quitação para as eleições que se avizinham ${ }^{205 \prime \prime}$.

Nas discussões entre os julgadores, surge a suposta contradição presente na legislação nova: o candidato que não apresenta as contas fica impedido de concorrer. No entanto, se ele procede à apresentação e elas forem reprovadas pela Justiça Eleitoral posteriormente, o postulante poderia concorrer ao pleito normalmente ${ }^{206}$. o

204 Processo Administrativo n. 594-59.2010.6.00.0000/DF. Rel. Min. Arnaldo Versiani. Rel. p/ acórdão Min. Ricardo Lewandowski, j. 03.08 .2010 .

205 Processo Administrativo n. 594-59.2010.6.00.0000/DF. Rel. Min. Arnaldo Versiani. Rel. p/ acórdão Min. Ricardo Lewandowski, j. 03.08 .2010$, p. 9.

206 A contradição foi apontada pelos Ministros Marcelo Ribeiro e Ricardo Lewandowski. 
Ministro Marcelo Ribeiro acentua a contradição, ao ressaltar que um cidadão que se ausenta em uma eleição não obtém a certidão; já o candidato que viola as regras legais de prestação de contas a obterá. Destaca-se que a aparente contradição também foi observada por doutrinadores ${ }^{207}$.

No mesmo sentido, o Ministro Marco Aurélio aponta outra interessante indagação: "não estaria na própria lei também a rejeição" de contas abarcada como hipótese de não obtenção da certidão de quitação eleitoral? o Min. Marco Aurélio segue seu raciocínio ressaltando que: (i) a interpretação do Relator "potencializa o aspecto formal em detrimento do conteúdo; (ii) apesar de não poder "perquirir a vontade dos legisladores", a nova regulamentação legal tem por objetivo, "sem dúvida alguma, (...) driblar a glosa ${ }^{208 \prime \prime}$.

O Min. Ricardo Lewandowski, em seu votovista, ressalta que O TSE não poderia posicionar-se na adoção da interpretação literal do $\$ 7^{\circ}$ do art. 11 da Lei das Eleições. A interpretação a ser feita deveria, sim, ser teleológica, levando em consideração a finalidade da norma, ou seja, pautar o processo eleitoral brasileiro pela normalidade e pela legitimidade do pleito.

Assim, o Min. Lewandowski conclui seu voto divergente no sentido de que o posicionamento do qual somente a não apresentação da prestação de contas de campanha eleitoral originaria a não obtenção da certidão de quitação eleitoral "esvaziaria por completo o processo de

207 PIMENTA JÚNIOR, Luciano Caleiro. "Desaprovação de contas de campanha e a 'perda' do cargo eletivo". In: Revista de doutrina e jurisprudência - Tribunal Regional Eleitoral de Minas Gerais, n. 20, 2010 , p. 58 .

208 Processo Administrativo n. 594-59.2010.6.00.0000/DF. Rel. Min. Arnaldo Versiani. Rel. p/ acórdão Min. Ricardo Lewandowski, j. 03.08 .2010 . 
prestação de contas, fazendo desse importante instrumento de controle da normalidade e da legitimidade do pleito uma mera formalidade, sem repercussão direta na esfera jurídica do candidato 209 ". No mesmo sentido, votaram os Ministros Marco Aurélio e Cármen Lúcia.

É possível também defender que o posicionamento do Ministro Lewandowski impede a afronta aos princípios constitucionais da moralidade administrativa (art. 37, caput, da Constituição), bem como do princípio da responsabilidade (art. 70 da Constituição), uma vez que "a mera apresentação das contas, ainda que de forma simbólica ou superficial, é suficiente à concessão da certidão de quitação eleitoral $210 "$.

Consoante o voto do Min. Arnaldo Versiani, o Min. Aldir Passarinho Junior entendeu que com a Minirreforma Eleitoral, "o legislador supriu esta lacuna, prevendo, expressamente, que, além dos demais requisitos legais, bastava a apresentação das contas para a obtenção da certidão de quitação eleitoral", pois "interpretação

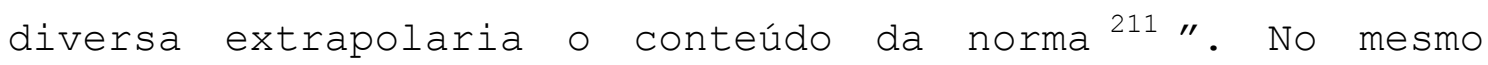
sentido, votou o Min. Marcelo Ribeiro.

A vitória do posicionamento do Min. Lewandowski se deu com o voto da Min. Nancy Andrighi, pois, no seu entender, "se a falta ou a extemporaneidade"

\footnotetext{
209 Processo Administrativo n. 594-59.2010.6.00.0000/DF. Rel. Min. Arnaldo Versiani. Rel. p/ acórdão Min. Ricardo Lewandowski, j. 03.08 .2010 .

210 CERQUEIRA, Thales Tácito; CERQUEIRA, Camila Albuquerque. Reformas eleitorais comentadas - Lei n. 12.034/2009 (minirreforma política e eleitoral) e LC n. 135/2010 (ficha limpa). São Paulo: Saraiva, 2010, p. 118 .

211 Processo Administrativo n. 594-59.2010.6.00.0000/DF. Rel. Min. Arnaldo Versiani. Rel. p/ acórdão Min. Ricardo Lewandowski, j. 03.08 .2010 .
} 
causavam o não fornecimento da quitação, "muito mais grave seria o fato de serem rejeitadas as contas ${ }^{212 " .}$

Esta interpretação vigeu por pouco tempo no TSE. Menos de dois meses depois, em decisão em sede de recurso especial eleitoral 213 , ou seja, em sede jurisdicional, o Tribunal mudou seu posicionamento: somente a não apresentação de prestação de contas de campanha eleitoral poderia ensejar a não obtenção da certidão de quitação eleitoral. Logrou êxito, portanto, a interpretação literal do $\$ 7^{\circ}$ do art. 11 da Lei das Eleições, incluído pela Lei n. 12.039/2009 (Minirreforma Eleitoral).

A nova decisão, em contrariedade à tomada em sede administrativa, se deu em virtude do voto do Min. Hamilton Carvalhido, julgador que não estava presente na sessão ocorrida em 03.08.2010. O Ministro do Superior Tribunal de Justiça entendeu que a sentença de rejeição de prestação de contas tem, como consequência legal, o cabimento da representação prevista no art. 30-A da Lei de Eleições. No mesmo sentido, Tiago Barroso certifica que "se as ações desconstitutivas de mandato eletivo e aplicativas de sanção de inelegibilidade são manejadas quando caracterizado o abuso eleitoral, não é coerente, por conseguinte, impedir o provimento da certidão de quitação eleitoral quando as contas forem apresentadas, mas desaprovadas, uma vez que a rejeição pode decorrer de questões formais ou procedimentais" $214 "$.

212 Processo Administrativo n. 594-59.2010.6.00.0000/DF. Rel. Min. Arnaldo Versiani. Rel. p/ acórdão Min. Ricardo Lewandowski, j. 03.08 .2010 .

213 REspe n. 4423-63.2010.6.21.0000/RS, Rel. Min. Arnaldo Versiani, j. 28.09 .2010 .

214 BARROSO, Tiago Aguiar Abreu Portela. "Quitação eleitoral e prestação de contas de campanha: a polêmica interpretação do $\$ 7^{\circ}$, art. 11, da Lei n 9.504/1997". In: Themis - Revista da Escola Superior da Magistratura do Estado do Ceará, v. 8, n. 2, ago/dez 2010, p. 189 . 


\begin{abstract}
O Ministro Carvalhido sustenta seu raciocínio ao trazer outro interessante elemento sobre o tópico em questão. Partindo-se da interpretação sistemática defendida pelos Ministros Marco Aurélio, Ricardo Lewandowski e Cármen Lúcia, a desaprovação das contas de campanha eleitoral deveria conduzir a Justiça Eleitoral à negativa de expedição de diploma ao candidato. Esta hipótese, ressalta Carvalhido, não tem qualquer previsão legal 215 .
\end{abstract}

Em seu voto, o Ministro Marco Aurélio insiste na tese de que a finalidade da norma em questão não era a apontada pelos Ministros Versiani e Carvalhido em sua interpretação literal. Na verdade, Marco Aurélio Mello leciona que

"É possível dizer-se, potencializando-se apenas o aspecto formal em detrimento do fundo, ser suficiente dirigir-se ao protocolo da Justiça Eleitoral e apresentar contas, pouco importando a boa ou a má procedência delas?

A meu ver, a própria ordem natural das coisas contraria a limitação que se pretende dar à parte final do $\S 7^{\circ}$ do artigo 11 da Lei $\mathrm{n}^{\circ}$ 9.504/1997. E, nesse caso, sim, haveria situação jurídica apenas de fachada, de vitrina, quanto ao ato positivo da apresentação das contas.

A finalidade da norma não é essa, a menos que também assentemos que, apresentadas as contas, haja o exaurimento do dever do candidato, não precisando sequer haver pronunciamento da Justiça Eleitoral sobre a regularidade. Ao interpretar-se que está quite com a Justiça Eleitoral quem apresentou contas em campanha e o fez de forma irregular, será necessário concluir - para sermos, no conjunto, no sistema, coerentes - que basta essa apresentação, não devendo haver qualquer exame ${ }^{216217}$,.

\footnotetext{
215 REspe n. 4423-63.2010.6.21.0000/RS, Rel. Min. Arnaldo Versiani, j. 28.09 .2010$, p. 19.

216 REspe n. 4423-63.2010.6.21.0000/RS, Rel. Min. Arnaldo Versiani, j. 28.09 .2010$, p. 22 .

217 Este argumento trazido por Marco Aurélio Mello rebate a tese de Versiani e de Carvalhido, que sustentaram que "a mera protocolização de expediente desacompanhado de documentação hábil àaferição da prestação de contas ou a sua apresentação intempestiva" não seriam suficientes à obtenção da certidão de quitação eleitoral. Vide REspe n. 4423-63.2010.6.21.0000/RS, Rel. Min. Arnaldo Versiani, j. 28.09 .2010$, p. 19-20.
} 
Assim sendo, a maioria formou-se com os votos dos Ministros Arnaldo Versiani, Hamilton Carvalhido, Marcelo Ribeiro e Aldir Passarinho Junior. No sentido contrário, votaram os três ministros do STF: Marco Aurélio, Ricardo Lewandowski e Cármen Lúcia.

Este posicionamento encontra eco na doutrina. David Schnaid Neto ensina que a interpretação criada pelo TSE por meio do art. 41, \$ $3^{\circ}$, da Resolução n. 22.715/2008 não tem mais efeito no ordenamento jurídico brasileiro, já que a regra trazida pela Minirreforma Eleitoral tem aplicabilidade imediata ${ }^{218}$. Aponta, no mesmo sentido, Tiago Aguiar Abreu Portela Barroso, ao assegurar que "é cediço afirmar que a irregularidade (desaprovação) na prestação de contas de campanha não é óbice ao fornecimento da certidão de quitação eleitoral, sendo vedada a expedição do documento somente nos casos em que ela for julgada como não prestadas $219 "$.

Em 2012, novamente houve polêmica no TSE com relação a decisões diametralmente opostas no que tange à abrangência da certidão de quitação eleitoral. A Resolução n. $23.376^{220}$, que dispunha sobre a arrecadação e os gastos de recursos por partidos políticos, candidatos e comitês financeiros e também sobre prestação de contas de campanha nas eleições de outubro daquele ano previa, em seu

\footnotetext{
218 SCHNAID NETO, David. "A consequência da alteração do conceito de quitação eleitoral para candidatos com contas de campanha desaprovadas". In: Paraná Eleitoral, n. 73, 2010, p. 104.

219 BARROSO, Tiago Aguiar Abreu Portela. "Quitação eleitoral e prestação de contas de campanha: a polêmica interpretação do $\$ 7^{\circ}$, art. 11, da Lei n 9.504/1997". In: Themis - Revista da Escola Superior da Magistratura do Estado do Ceará, v. 8, n. 2, ago/dez 2010, p. 188 .

220 Instrução n. 1542-64.2011.6.00.0000/DF, Resoluçãon. 23.376, Rel. Min. Arnaldo Versiani, j. 0103.2012
} 
art. $52^{221}$, a impossibilidade da obtenção da certidão de quitação eleitoral para os candidatos que tivessem suas prestações de contas rejeitadas.

Essa decisão, entretanto, perdurou por pouco tempo. Representação ${ }^{222}$ apresentada pelo PT e endossada por mais treze partidos (PMDB, PSDB, DEM, PTB, PR, PSB, PP, PSD, PRTB, PV, PCdoB, PRP e PPS) resultou na revogação do $\$ 2^{\circ}$ do art. 52 da Resolução 23.376/2012, pacificando, por ora, a questão, qual seja: somente a hipótese de não apresentação da prestação de contas de campanha eleitoral enseja a não obtenção da certidão de quitação eleitoral no momento do registro de candidatura.

Mais uma vez, é forçoso reconhecer que o contexto político e judicial envolvendo a definição da abrangência da certidão de quitação eleitoral traz à baila - fato de decisões do Judiciário sofrerem oposição do Legislativo, assim como dos partidos políticos.

Este subitem comprovou que após o endurecimento da definição de certidão de quitação eleitoral, em 2008, quando O TSE ampliou sua interpretação, fato este que potencialmente diminuiria 0 número de candidatos nas eleições seguintes, o Congresso Nacional reagiu, aprovando dispositivo legal que restringia a interpretação do TSE prejudicial à classe política.

\footnotetext{
221 "Art. 52. A decisão que julgar as contas dos candidatos eleitos será publicada até 8 dias antes da diplomação (Lei n 9.504/97, art. 30, \$ $1^{\circ}$ ).

$\$ 1^{\circ} \mathrm{Na}$ hipótese de gastos irregulares de recursos do Fundo Partidário ou da ausência de sua comprovação, a decisão que julgar as contas determinará a devolução do valor correspondente ao Tesouro Nacional no prazo de 5 dias após o seu trânsito em julgado.

$\$ 2^{\circ}$ Sem prejuízo do disposto no $\$ 1^{\circ}$, a decisão que desaprovar as contas de candidato implicará o impedimento de obter a certidão de quitação eleitoral."

222 Instrução n. 1542-64.2011.6.00.0000/DF, Resoluçãon. 23.382, Rel. Min. Arnaldo Versiani, j. 28.06.2012.
} 
O TSE, porém, demorou quase três anos

para pacificar e, consequentemente, solidificar seu posicionamento jurisprudencial sobre o tema, ao adotar a interpretação literal do dispositivo incluído na Lei das Eleições pela Minirreforma Eleitoral. Essa interpretação, entretanto, concedeu maior espaço para os candidatos desrespeitarem as regras concernentes à prestação de contas de campanhas eleitorais, consequência esta não salutar para a democracia brasileira.

Terminado o presente capítulo, ganhará corpo o exame do fenômeno do ativismo judicial na Justiça Eleitoral. O próximo capítulo terá como foco a decisão do TSE que instituiu a verticalização das coligações partidárias, sob o prisma do ativismo judicial. 


\section{Caso concreto: a Verticalização das coligações partidárias}

\subsection{Introdução}

No início de 2002, ano de eleições estaduais e para a Presidência da República, uma decisão em sede de Consulta proferida pelo Tribunal Superior Eleitoral trouxe à tona nova polêmica na relação entre o Poder Judiciário e o Poder Legislativo no campo da legislação político-eleitoral.

A verticalização das coligações partidárias decorreu da interpretação do TSE em relação ao princípio da coerência nas coligações partidárias. Esta nova visão do tribunal eleitoral teve como principal consequência o surgimento de um parâmetro legal para os partidos políticos seguirem nas negociações políticas visando ao registro de candidaturas para os cargos de presidente da República, governadores de Estado, deputados federais, estaduais, distritais e senadores, que segundo a Lei das Eleições, deveria ocorrer até o início de julho do mesmo ano.

A decisão foi saudada por muitos atores do cenário político brasileiro. Fernando Henrique Cardoso (PSDB), então presidente da República, por exemplo, declarou que a decisão era o início da reforma política no Brasil 223 . Foi acusado, porém, de ter avalizado a decisão com objetivos eleitorais 224225 . A reação da maioria dos

223 RODRIGUES, Fernando. "'A reforma política começou', diz presidente". In: Folha de S. Paulo, edição de 28.02.2002. In: <http://wwwl.folha.uol.com.br/fsp/brasil/fc2802200204.htm>. Acesso em 26.12 .2013 .

224 Reportagem dos jornalistas Valdo Cruz e Kennedy Alencar publicada no jornal Folha de S. Paulo, edição de 28.02 .2002 relatou que Fernando 
congressistas e dos partidos políticos, no entanto, foi contrária à decisão do TSE que engessou as possibilidades de coligações partidárias nas eleições gerais de 2002 .

A reação inicial do Congresso Nacional foi rápida: foi apresentada uma proposta de emenda constitucional com o objetivo de eliminar a obrigatoriedade da verticalização das coligações.

A verticalização das coligações partidárias surgiu no ordenamento político-eleitoral brasileiro após decisão proferida pelo Tribunal superior Eleitoral em sede de Consulta. Como já estudado anteriormente, o Código Eleitoral prevê, em seu art. 23, inciso XII, excepcionalmente, a possibilidade de autoridade com jurisdição federal ou órgão nacional de partido político apresentar consulta ao TSE.

Assim sendo, deputados federais filiados ao Partido Democrático Trabalhista (PDT) protocolizaram consulta ao TSE com o seguinte questionamento:

Henrique Cardoso avalizou a decisão proferida pelo Tribunal Superior Eleitoral com o objetivo de "reunir os partidos de sua base parlamentar em torno de seu candidato a presidente, o senador José Serra (PSDB-SP)." Folha de S. Paulo, edição de 28.02.2002, "FHC avalizou decisão do TSE quem em tese, beneficia Serra". In: <http://www1.folha.uol.com.br/fsp/brasil/fc2802200202.htm>. Acesso em 26.12 .2013 .

225 Em edição publicada em 25.01.2006, mais uma vez, o jornal Folha de S. Paulo relatou que Fernando Henrique Cardoso deu aval ao presidente do TSE em 2002, Nelson Jobim, para a adoção da interpretação da verticalização das coligações, com o objetivo de garantir uma forte coligação ao candidato de seu partido na corrida ao Palácio do Planalto, José Serra. A mesma reportagem informa que essa decisão, na visão do ex-presidente da República, prejudicaria as chances do Partido dos Trabalhadores em proceder à aliança eleitoral com o Partido Liberal, fato que, posteriormente, acabou ocorrendo. Folha de S. Paulo, edição de 25.01.2006, "Verticalização foi decretada pelo TSE com de Fival FHC". In: http://wwwl.folha.uol.com.br/fsp/brasil/fc2501200603.htm>. Acesso em 26.12.2013. 
"Pode um determinado partido político (partido A) celebrar coligação, para eleição de Presidente da República, com alguns outros partidos (partido B, C e D) e, ao mesmo tempo, celebrar coligação com terceiros partidos (E, F e G, que também possuem candidato à Presidência da República) visando à eleição de Governador de Estado da Federação?"

Os ministros do TSE, por maioria (cinco votos a dois), responderam negativamente à consulta. A decisão gerou a Resoluçãon. 21.002, de 26 de fevereiro de $2002^{226}$. O principal o objetivo dessa nova resolução foi enfatizar a previsão constitucional o caráter nacional dos partidos políticos, confirme disposto no inciso I do art. 17 da Constituição ${ }^{227}$.

Na prática, essa decisão dificultava sobremaneira a formação de coligações em âmbito estadual ou distrital. Ao menos com os parâmetros até então estabelecidos pela lei e pela jurisprudência vigentes. Em oportunidade anterior, exemplificamos o engessamento das coligações partidárias nas eleições de 2002, conforme trecho a seguir:

Assim sendo, nas eleições gerais (nacionais e estaduais), as coligações formadas dentro de cada Estado não poderão contrariar a coligação formada para a eleição presidencial. Portanto, lembrando as coligações formadas em 2002, quando o PT aliou-se ao PL para eleger Luiz Inácio Lula da Silva, por exemplo, em nenhum Estado da Federação os liberais ou os petistas poderiam aliar-se ao PSDB ou ao PMDB, que formaram outra aliança em torno do candidato José Serra. O PT poderia até ter um candidato ao governo estadual e o PL outro postulante, mas a verticalização impede qualquer aliança com agremiações que participem de outra aliança no âmbito nacional. Se o partido resolver não lançar candidato à Presidência e também não se coligar com outra agremiação [na eleição presidencial], está livre pata formar

\footnotetext{
226 Cta. n. 715/DF. Resolução n. 21.002. Rel. Min. Garcia Vieira, j. 26.02 .2002 .

227 "Art. 17. É livre a criação, fusão, incorporação e extinção de partidos políticos, resguardados a soberania nacional, o regime democrático, o pluripartidarismo, os direitos fundamentais da pessoa humana e observados os seguintes preceitos:

I - caráter nacional;"
} 
alianças com quem quiser [nos Estados], assim como fez o PFL em $2002^{228}$.

Além dos efeitos práticos, o julgamento do TSE que mudou diametralmente o entendimento até então vigente das normas sobre as coligações partidárias gerou diversos efeitos políticos e eleitorais.

Primeiramente, houve uma reação dos partidos políticos. Duas legendas ajuizaram ações diretas de inconstitucionalidade visando à extirpação de referida Resolução do ordenamento jurídico brasileiro no Supremo Tribunal Federal. Resumidamente, os partidos autores alegaram que a Resolução do TSE ora combatida desrespeitava - princípio da anterioridade eleitoral previsto no art. 16 da Constituição ${ }^{229}$.

A reação mais contundente, ao menos inicialmente, foi perpetrada pelo Poder Legislativo. Foi apresentada e discutida uma proposta de emenda constitucional (PEC) que serviria como antídoto à nova interpretação proferida pelo TSE.

O projeto consistia, basicamente, em duas mudanças na constituição. A primeira delas ampliava a autonomia partidária prevista no $\$ 1^{\circ}$ do art. 17, evidenciando que ela se estendia à adoção dos critérios para a escolha das coligações eleitorais. Já a segunda tratava da vedação a qualquer obrigatoriedade de vinculação dessas alianças às candidaturas no âmbito nacional,

228 REIS, Daniel Gustavo Falcão Pimentel dos. Verticalização das coligações partidárias: melhor caminho para a coerência políticoeleitoral? Disponível em: <http://www.sbdp.org.br/artigos_ver.php?idConteudo=42>. Acesso em 11 . 10. 2010 .

229 "Art. 16. A lei que alterar o processo eleitoral entrará em vigor na data de sua publicação, não se aplicando à eleição que ocorra até um ano da data de sua vigência." 
estadual, distrital ou municipal. Por fim, a PEC previa também que, se aprovada, seu texto já vigeria para as eleições de 2002 .

Como poderá ser visto com maior propriedade nos itens subsequentes, as ações diretas não prosperaram, assim como a PEC apresentada no Congresso Nacional não avançou. Deste modo, o princípio da coerência nas coligações partidárias, materializada na interpretação do TSE que resultou na Resolução n. 21.002/2002 vigeu nas eleições de outubro de 2002.

Somente no início de 2006, quando novamente ocorreriam eleições gerais, que a verticalização voltou à tona no panorama político brasileiro.

Após a protocolização de nova consulta ${ }^{230}$ por Ronaldo Nóbrega Medeiros, secretário-geral da Comissão Executiva Nacional do Partido Social Liberal (PSL), O TSE confirmou a vigência da verticalização para as eleições de outubro de $2006^{231}$.

Confirmada a vigência da verticalização nas eleições de 2006, a PEC apresentada em 2002 foi subitamente promulgada pelo Congresso Nacional, em oito de março de 2006, ou seja, apenas cinco dias após o julgamento do TSE.

\footnotetext{
230 A consulta consistia na seguinte pergunta: "Pode um determinado partido político, via Resolução do Órgão Nacional, publicada no Diário Oficial da União, até dento e oitenta dias antes das eleições, estabelecer normas que autorizem coligações híbridas que não respeitem - paradigma da coligação nacional, ou seja, possam livremente estabelecer coligações partidárias nas eleições estaduais, no entendimento do art. $7^{\circ}, \$ 1^{\circ}$, da Lei $n^{\circ} 9.504$ de 30 de setembro de 1997, nas formações das coligações?".

${ }^{231}$ Cta. n. 1.185/DF. Resolução n. 22.161. Rel. Min. Marco Aurélio.

Rel.p/ resolução Min. Caputo Bastos, j. 03.03.2006.
} 
A consequência imediata da promulgação da Emenda Constitucional n. 52 foi a protocolização de uma nova ação direta de inconstitucionalidade no STF. Dessa vez, no entanto, o autor da ação foi o Conselho Federal da Ordem dos Advogados do Brasil, com o objetivo de afastar a eficácia da EC n. 52/2006 para as eleições de outubro daquele ano.

A decisão do STF confirmou, mais uma vez, a vigência da verticalização das coligações partidárias nas eleições gerais de 2006. O Pleno, por maioria, entendeu que a EC n. 52/2006 não tinha aplicação imediata, em razão do princípio constitucional da anterioridade eleitoral. Referida emenda, no entanto, retirou a regra da verticalização das eleições gerais seguintes.

Todo o processo político e jurisdicional envolvendo a verticalização das coligações partidárias demonstra claramente que já havia, no início da década passada, certa divergência entre os Poderes Legislativo e Judiciário. Atores políticos, quando contrariados, procuraram usar de mecanismos constitucionais para fazer valer suas posições e seus interesses.

Pouco tempo depois, uma sequência de decisões proferidas pelo TSE e pelo STF produziram ainda mais polêmica e consequências duradouras ao panorama político brasileiro, acentuando o entendimento de que o Judiciário estava se imiscuindo de assuntos afeitos ao Legislativo. A verticalização, grande novidade das eleições de 2002, tornou-se um dos vários exemplos dessa relação conturbada entre o Legislativo e o Judiciário em temas políticos-eleitorais. 
Assim, para seguirmos na análise, devemos ter como premissa básica a definição de verticalização (princípio da coerência nas coligações partidárias): os partidos políticos, nas eleições gerais (presidente da República, Governador, Senador, Deputado Federal, Deputado Estadual e Deputado Distrital) não poderiam formar coligações nas eleições estaduais com outros partidos políticos que foram seus adversários na eleição à Presidência da República.

Introduzido o tema deste capítulo, devemos trazer qual é a divisão desta parte do trabalho. Primeiramente, faremos uma análise do regime normativo das coligações no Brasil, com foco no art. $6^{\circ}$ da Lei das Eleições. Neste item, haverá também estudo sobre a primeira decisão do TSE, em sede de Consulta, sobre referido dispositivo legal, na seara das eleições de 1998.

Em seguida, haverá o exame pormenorizado dos argumentos trazidos pelos Ministros na decisão do TSE da qual adveio a interpretação de que nas eleições gerais, vigeria a verticalização, ou seja, o princípio da coerência das coligações partidárias. O quarto item deste capítulo trará a tona outras cinco decisões do TSE que explicitaram seu posicionamento original sobre a verticalização.

O quinto item trará análise sobre a decisão do Supremo Tribunal Federal, em sede de ação direta de inconstitucionalidade, à provocação de partidos políticos requerendo a extirpação da verticalização do ordenamento jurídico brasileiro. Foi esse julgamento que confirmou a vigência do princípio da coerência nas eleições de 2002 . 
A parte seguinte tratará da reação do Congresso Nacional à decisão do TSE, com destaque ao trâmite da proposta que resultou na promulgação, em 2006, da Emenda Constitucional n. 52. Uma rápida análise de duas decisões do TSE exaradas em 2003 e 2005 será o foco da sétima parte do capítulo em voga.

Passamos, no oitavo item, ao exame de nova decisão do TSE que confirmou a vigência da verticalização nas eleições de 2006. Esta decisão gerou, como já explicitado, a promulgação da EC n. 52/2006. No item seguinte, o foco será nova decisão do Supremo em sede de controle de constitucionalidade concentrado. Dessa vez, a norma impugnada é a emenda anteriormente referida. Este julgamento chancelou a decisão do TSE no sentido de que a verticalização vigeria no pleito de 2006.

A trajetória de análises de decisões não se encerra aqui. Após o julgamento do STF, em março de 2006, O TSE foi novamente provocado, em sede de Consulta, sobre os limites da verticalização. Três decisões antagônicas foram tomadas, resultando, após intenso debate que também será estudado aqui, na manutenção da interpretação original sobre a verticalização. Por fim, o décimo primeiro item do capítulo tratará da última decisão exarada pelo TSE sobre o tema, confirmando a vigência da EC n. 52/2006, emenda esta que encerrou definitivamente com a verticalização das coligações partidárias no Brasil.

Devemos rememorar que toda a análise das decisões exaradas pelo STF e pelo TSE no tema terão enfoque sob o ângulo da conceituação do fenômeno do ativismo judicial trazida à tona no Capítulo 2 desta tese. Demonstraremos, com a análise de todas estas decisões, que 
- TSE, com a chancela do STF, ultrapassou os limites legais

e constitucionais existentes e, de forma ativista, inovou a legislação eleitoral quando do regime normativo das coligações partidárias.

\subsection{Regime normativo das coligações partidárias no Brasil}

\subsubsection{Lei das Eleições (Lei n. 9.504/97)}

O art. $6^{\circ}$ da Lei n. 9.504/97, mais conhecida como Lei das Eleições (LE), dispõe sobre as coligações partidárias. O "caput" do art. $6^{\circ}$ foi o objeto que iniciou toda a discussão sobre verticalização na Justiça Eleitoral e, posteriormente, no STF.

Coligação é a aliança entre dois ou mais partidos políticos celebrada para a disputa do pleito eleitoral. É considerada uma espécie de "ficção legal232".

A interpretação do "caput" do art. $6^{\circ}$, até o advento da verticalização, consistia na proibição de coligação, na eleição proporcional, entre partidos que não estivessem coligados na eleição majoritária. Renato Ventura Ribeiro aponta duas falhas nessa interpretação.

A primeira versa no fato de que a possibilidade de se fazer várias coligações na eleição proporcional dentre aqueles que fazem parte de uma aliança majoritária permite a um grupo político tomar um partido

\footnotetext{
${ }^{232}$ No mesmo sentido, Renato Ventura Ribeiro (Lei eleitoral comentada. São Paulo: Quartier Latin, 2006, p. 78); Olivar Coneglian define coligação como "pessoa jurídica formal, de direito privado, nascida da união de partidos, com o objetivo de participar das eleições, tendo duração finita no tempo, durante o processo eleitoral". (In: Lei das eleições comentada. Curitiba: Juruá, 2009, p. 43).
} 
político na sua coligação visando a aumentar excessivamente - número de candidatos proporcionais. O segundo problema apontado pelo autor incide no fato de que se permite a formação de coligações proporcionais entre as agremiações que não fizeram parte da eleição majoritária, coligadas ou não ${ }^{233}$.

As coligações devem ser celebradas no período de convenção partidária $(10$ a 30 de junho do ano eleitoral). Há duas hipóteses de nulidade das coligações. A primeira delas é no caso de vícios formais, conforme estatuto partidário. A segunda hipótese cinge-se no fato de a deliberação de órgão inferior ser contrária à diretriz do diretório superior (art. $7^{\circ}$, caput e $\$ 2^{\circ}$ ).

O \$ $1^{\circ}$ dá à coligação força de partido político no que se refere a processo eleitoral. As coligações recebem as prerrogativas e obrigações de uma agremiação, como se partido fosse. Essa possibilidade também se dá no relacionamento da coligação com a Justiça Eleitoral e também no trato de interesses interpartidários ${ }^{234}$.

No que toca ao processo eleitoral, a coligação, se existente, assume o papel dos partidos políticos do qual fazem parte e passa a ser responsável pelos registros de candidatura, pela propaganda eleitoral e pelas questões de decorrentes da realização da votação e também da apuração. A coligação substitui os partidos processualmente a partir do registro das candidaturas. Assim, o partido político participante de coligação só tem

\footnotetext{
${ }^{233}$ Cf. RIBEIRo, Renato Ventura. Lei eleitoral comentada. São Paulo: Quartier Latin, 2006, p. 78 .

${ }^{234}$ Cf. RIBEIRo, Renato Ventura. Lei eleitoral comentada. São Paulo: Quartier Latin, 2006, p. 93.
} 
legitimidade ativa para agir de forma isolada quando a lide tiver como causa dissidência interna ou quando houver questionamento da própria validade da coligação.

Uma importante consequência eleitoral propriamente dita da formação de coligação diz respeito às eleições proporcionais. Numa aliança eleitoral em sede proporcional, no momento da verificação dos quocientes partidário e eleitoral, a coligação é encarada como um único partido. Os candidatos desta coligação, independentemente de qual partido fazem parte, formam uma lista única. Sendo assim, são eleitos os mais votados da coligação como um todo, sem se levar em conta qual o partido em que o postulante é filiado. Na suplência, funciona da mesma forma: a lista é da coligação, e não de cada partido em separado.

\subsubsection{Resolução n. $20.126 / 98$ do TSE (Consulta n. 382)}

A primeira oportunidade que teve $O$ TSE para examinar o alcance interpretativo na Lei das Eleições no que tange às coligações partidárias se deu com a Consulta n. 382/DF, apresentada pelo então deputado federal Pedro Henry (PSDB/Mato Grosso).

A Consulta consistia nos seguintes questionamentos relativos à interpretação do art. $6^{\circ}$ da Lei das Eleições:

“1. Qual das eleições, majoritária ou proporcional, é possível a coligação: Governador - Deputado Federal ou Governador Deputado Estadual? Senador?

2. É possível coligações diferentes para Governador -

3. A qual eleição majoritária está vinculada a eleição proporcional e a qual eleição proporcional está vinculada a eleição majoritária? Exemplos: 
- Coligação para eleição a Governador formada pelos partidos $\mathrm{A}+\mathrm{B}+\mathrm{C}+\mathrm{D}+\mathrm{E}+\mathrm{F}$, é possível coligações diferentes para eleição a Senador? Exemplo:

Coligação 1: Partidos $\mathrm{A}+\mathrm{B}+\mathrm{C}$

Coligação 2: Partidos D+E+F

- Para eleição a Deputado Federal (proporcional) é possível coligações diferentes? Exemplo:

Coligação 1: Partidos A+D+E

Coligação 2: Partidos D+E+F

- Para eleição a Deputado Estadual (proporcional), é possível

Coligação 1: Partidos $\mathrm{A}+\mathrm{F}$

Coligação 2: Partidos $\mathrm{B}+\mathrm{D}$

Coligação 3: Partidos $\mathrm{C}+\mathrm{E}$

4. Considerando-se que a coligação da eleição proporcional para Deputado Federal seja a mesma da eleição majoritária para Governador, formadas pelos partidos $\mathrm{A}+\mathrm{B}+\mathrm{C}+\mathrm{D}+\mathrm{E}+\mathrm{F}$, poderão ser formadas coligações diferentes para a eleição de Deputados Estaduais?

Exemplo:

- Governador/Deputado Federal: Coligação Partidos $\mathrm{A}+\mathrm{B}+\mathrm{C}+\mathrm{D}+\mathrm{E}+\mathrm{F}$

- Deputado Estadual: Coligação 1: Partidos A+B

Coligação 2: Partidos $\mathrm{C}+\mathrm{D}$

Coligação 3: Partidos E+F ou,

Coligação 1: Partidos $\mathrm{A}+\mathrm{B}+\mathrm{E}$

Coligação 2: Partidos $\mathrm{C}+\mathrm{D}$

Isolado: Partido F".

O Ministro Relator Néri da Silveira inicia seu voto destacando a instabilidade legislativa no que toca às coligações partidárias (vide item 4.4.1). No voto, o Ministro relembra a Lei n. $7.493 / 86$, que, no $\$ 2^{\circ}$ do art. $6^{\circ}$, vedava a celebração de coligações diferentes para as eleições majoritárias e proporcionais. A Lei das Eleições Municipais de 1988 (Lei n. 7.664, de 29.06.1988)e a Lei n. 8.214, de 24.07.1991 (para as eleições municipais de 1992) continham o mesmo dispositivo (art. $8^{\circ}, \$ 1^{\circ} \mathrm{e}$ art. $6^{\circ}, \$ 1^{\circ}$, respectivamente).

A Lei para as eleições gerais de 1996 (Lei n. 9.100, de 29.09.1995), porém, continha texto diferente. O art. $6^{\circ}$ garantia aos partidos políticos que as coligações seriam admitidas "se celebradas conjuntamente para as eleições majoritária e proporcional, e integrada pelos mesmos partidos, ou se celebradas apenas para as 
eleições majoritárias". Não havia a possibilidade, portanto, de coligação exclusivamente proporcional.

Por fim, a Lei das Eleições (Lei $n$. 9.504, de 30 de setembro de 1997), preceituou, em seu art. $6^{\circ}$, que era

"facultado aos partidos políticos, dentro da mesma circunscrição, celebrar coligações para eleição majoritária, proporcional, ou para ambas, podendo, neste último caso, formarse mais de uma coligação para a eleição proporcional dentre os partidos que integram a coligação para o pleito majoritário".

Assim, a atual Lei das Eleições previu nitidamente a possibilidade de se celebrar, na eleição proporcional, "mais de uma coligação". Néri da Silveira completa dizendo que a lei exige, "porém, que as coligações diferentes, eventualmente a se formarem, provenham 'dentre os partidos que integram a coligação para o pleito majoritário'235".

Assim, em nossa visão e também na ótica do Ministro Relator, a Lei das Eleições, em seu art. $6^{\circ}$, não permitiu a pluralidade de coligações nas eleições majoritárias, mas sim para o pleito proporcional. Há a possibilidade de os partidos se coligarem somente na eleição majoritária ou na proporcional.

A possibilidade de formação de "mais de uma coligação para a eleição proporcional", no entanto, decorre necessariamente de uma aliança formada na eleição majoritária ${ }^{236}$.

${ }^{235}$ Cta. n. 382/DF, Rel. Min. Néri da Silveira. Resoluçãon. 20.126, de 12 de março de 1998.

${ }^{236}$ Utilizado o exemplo inicial apresentado pelo deputado consulente, na coligação majoritária $A+B+C+D+E+F$, estes seis partidos estão livres para formarem aliança na eleição proporcional entre eles. Não é possível quaisquer desses seis partidos formarem coligações com partidos que estão fora da aliança majoritária. Mas, na eleição 
Como dito anteriormente, 0 art. $6^{\circ}$ determina que para a eleição majoritária há a possibilidade de apenas uma coligação. Assim, não existe permissão legal para a formação de uma aliança eleitoral-partidária visando à eleição para governador e outra para a cadeira no Senado Federal. O Ministro Néri da Silveira consignou da mesma interpretação em seu voto, ao afirmar que "não autoriza, destarte, o texto legal se lhe confira exegese segundo a qual possam coexistir duas coligações no âmbito da eleição majoritária, com base no mesmo bloco de partidos ${ }^{237 " .}$

Néri da Silveira, acompanhado por unanimidade 238 , nem mesmo admitiu a possibilidade de que um partido coligado na eleição majoritária pudesse apresentar candidatura ao Senado em separado. Reconhece o Ministro Relator que as candidaturas majoritárias estaduais são separadas, autônomas, mas ambas, porém, advém da mesma circunscrição (a estadual) ${ }^{239}$.

\footnotetext{
proporcional, pode haver coligações das mais diversas dentre os seis partidos, bem como um ou todos eles não se coligarem nas proporcionais. O Ministro Néri da Silveira trouxe, em seu voto, exemplo na mesma toada: "De outra parte, composta a coligação para a eleição majoritária de diversos partidos, ad exemplum, de seis partidos: ' $A$ ', ' $B$ ', ' $C$ ', ' $D$ ', ' $E^{\prime}$ ' ${ }^{\prime} F^{\prime}$ ' é possível que se constituam três coligações na eleição proporcional: ' $A$ ' $e$ ' $B$ '; ' $C$ ' $e$ ' $D$ '; 'E' e ' $F$ ', ou, apenas, duas: ' $A$ ', ' $B$ ', ' $C$ ' $e$ ' $D$ ', ao lado de outra integrada por 'E' $e$ ' $E^{\prime}$ ', ou ainda, duas coligações, sendo uma: 'A', 'B', 'C', $e$ a outra: ' $E$ ' $e$ ' $F$ ', permanecendo, entretanto, o partido ' $D$ ' fora de coligação para o pleito proporcional, no intento de concorrer com candidatos próprios".

${ }^{237}$ Cta. n. 382/DF, Rel. Min. Néri da Silveira. Resolução n. 20.126, de 12 de março de 1998.

${ }^{238}$ Votaram com o Ministro Relator os seguintes Ministros: Ilmar Galvão, Sydney Sanches, Nilson Naves, Eduardo Ribeiro, Eduardo Alckmin e Costa Porto.

${ }^{239}$ Para Néri da Silveira, o "espírito do art. 6 da Lei n 9.504/1997, que, em se formando uma coligação para o pleito majoritário, aí se entendam, em princípio, compreendidos os cargos de Governador e Senador, exegese essa, à semelhança do que se examinou acima, única a viabilizar a aplicação da segunda parte do dispositivo concernente à eleição proporcional, com coligações diversas".
} 
$\mathrm{Na}$ eleição proporcional, os partidos pertencentes a uma coligação majoritária estão liberados a celebrarem, entre as agremiações pertencentes a esta aliança, coligações diversas se comparadas as eleições para deputados federais e estaduais ${ }^{240}$.

Por fim, Néri da Silveira enfatiza que, apesar da ampla abertura conferida pelo art. $6^{\circ}$ da Lei $n$. 9.504/97, houve a adoção do princípio do parâmetro inafastável, "qual seja, manter-se fechado o círculo partidário que ampara a eleição majoritária241". Assim, os partidos que participam de uma coligação majoritária (eleição para Governador e Senador) terão total liberdade para exercerem seu interesse próprio em celebrar ou não coligações nas eleições proporcionais (deputado federal e deputado estadual) entre eles, não havendo a possibilidade de se coligarem com partidos que façam parte de outra coligação dentro da circunscrição.

Desse modo, o TSE respondeu à consulta da seguinte forma:

a) No item 1: celebrada a coligação para Governador, esta mesma coligação "pode disputar a eleição proporcional para Deputado Federal ou para Deputado Estadual ou para ambos";

b) No item 2 consignou-se que "não é possível a existência de coligações diferentes entre os mesmos partidos" nos pleitos visando aos postos de

\footnotetext{
${ }^{240}$ Utilizando-se do mesmo exemplo da Consulta, portanto, numa coligação majoritária $A+B+C+D+E+F$, podem os partidos celebrarem coligações entre si diversas para as eleições de deputado federal e deputado estadual. Assim, para a Câmara dos Deputados, O partido A se coliga com O B; para a Assembleia Legislativa, há a autorização legal de o partido A coligar-se com C, D, E, F ou mesmo com B e algum outro participante da mesma coligação majoritária.

${ }^{241}$ Cta. n. 382/DF, Rel. Min. Néri da Silveira. Resolução n. 20.126, de 12 de março de 1998.
} 
Governador e Senador. Os partidos podem, porém, lançar candidatos isoladamente;

c) No item 3, restou prejudicada a consulta, ante as respostas do TSE aos itens 2 e 4;

d) No item 4, o TSE admitiu a celebração de coligações diversas dentre os partidos que fazem parte de uma coligação majoritária em comum, "quer para a eleição de Deputado Federal, quer para a de Deputado Estadual", havendo também a possibilidade de o partido participante da coligação majoritária não celebrar nenhuma aliança proporcional.

A análise desta decisão é fundamental para o melhor entendimento do surgimento da interpretação, quatro anos depois, da verticalização das coligações partidárias por três motivos.

Primeiramente, a decisão da Consulta n . 382/DF demonstra que, mesmo havendo pormenorizada análise interpretativa do texto do art. $6^{\circ}$ da Lei das Eleições por parte do TSE, não houve qualquer tipo de menção à obrigação dos partidos respeitarem qualquer coerência ideológica ao celebrarem coligações.

A coerência exigida pelo TSE nas coligações realizadas nas eleições de 1998 é de natureza prática nas eleições majoritárias dentro da mesma circunscrição. Assim, a coligação majoritária deve lançar, conjuntamente, naquele Estado-membro, um candidato ao Governo do Estado e um candidato ao Senado Federal ${ }^{242}$.

\footnotetext{
242 O voto do Ministro Néri da Silveira clarifica a questão: "Não tenho, em realidade, como viável se constitua uma coligação para Governador e outra diferente para Senador: de contrário, se diversos grupos de agremiações partidárias, não seria possível atender à parte final do art. $6^{\circ}$ referido, no sentido da constituição de duas ou mais coligações com vista ao pleito proporcional, ao se estipular que, aí,
} 
Segundo, nota-se com clareza ímpar que, para O TSE, nas eleições gerais, há duas circunscrições diferentes: (i) a nacional (eleição para Presidente da República) e (ii) a estadual (eleição para Governador, Senador, Deputado Federal e Deputado Estadual).

Era evidente para o TSE que nas eleições gerais, havia, na verdade, 28 (vinte e oito) circunscrições eleitorais diferentes: 26 (vinte e seis) circunscrições estaduais (eleição para governador, senador, deputado federal e deputado estadual em cada Estado-membro); uma circunscrição distrital (eleição para governador, senador, deputado federal e deputado distrital no Distrito Federal) e, por fim, a circunscrição nacional (eleição para Presidente da República). Tanto é que não houve, nesta decisão, qualquer tipo de menção a uma possível necessidade ou mesmo obrigação de as coligações majoritárias serem as mesmas na eleição nacional e estadual.

Esta constatação será fundamental para que possamos analisar a decisão que instituiu a verticalização das coligações partidárias no Brasil em 2002 .

\subsection{Resolução 21.002 do TSE (Consulta n. 715): criação interpretativa da Verticalização}

$$
\text { A verticalização das coligações }
$$

partidárias no Brasil nasceu em fevereiro de 2002. Os deputados federais filiados ao PDT Miro Teixeira (Rio de Janeiro), José Roberto Batochio (São Paulo), Fernando

as coligações se façam dentre os partidos que integram a coligação para o pleito majoritário". 
Coruja (Santa Catarina) e Pompeo de Mattos (Rio Grande do Sul) protocolizaram Consulta no TSE com o seguinte questionamento:

"Pode um determinado partido político (partido A) celebrar coligação, para eleição de Presidente da República, com alguns outros partidos (partido B, C e D) e, ao mesmo tempo, celebrar coligação com terceiros partidos (E, F e G, que também possuem candidato à Presidência da República) visando à eleição de Governador de Estado da Federação? $?^{243}$,

Já mencionamos anteriormente que a consulta foi respondida negativamente, por maioria de votos. Diante da importância deste item para a consecução do trabalho, ele será dividido em dois subitens: argumentos a favor da verticalização e contrários a sua vigência. Cada argumento trazido pelos Ministros do TSE ganharão um subitem especial. Faremos a análise dessa forma no intuito de facilitar ao leitor desta tese no sentido de entender quais argumentos foram trazidos nesse leading case tão importante. Ao final do item, traremos nossas considerações sobre a decisão sob a ótica do fenômeno do ativismo judicial.

\subsubsection{Argumentos pró-verticalização}

Primeiramente, serão examinados os argumentos vencedores na ocasião, ou seja, as alegações trazidas pelos Ministros para mudar diametralmente a interpretação doutrinária (vide item 4.2.1 supra) e do próprio TSE (vide item 4.2.2 supra) sobre o tema. Assim, esse subitem será dividido em cinco tópicos. Alguns deles não foram citados por todos os Ministros ao responderem negativamente à consulta.

243 Cta. n. 715/DF, Rel. Min. Garcia Vieira, Resolução n. $21.002, j$. 26.02 .2002 . 
Nossa intenção, mesmo sendo um argumento citado en passant, é tentar entender com profundidade o que levou os magistrados eleitorais a mudarem de forma tão radical a interpretação vigente na eleição geral anterior (1998). Ao mesmo tempo, no intuito de fazermos um exame crítico desses argumentos, demonstraremos de fato a premissa inicial desta tese: o advento da verticalização das coligações se tratou de um caso concreto em que o Tribunal Superior Eleitoral ultrapassou seus limites legais e constitucionais. A verticalização, no nosso entender, não foi resultado de mera interpretação da Lei das Eleições, mais sim uma verdadeira inovação normativa.

\subsubsection{Caráter nacional dos partidos politicos}

O Relator da Consulta n. 715, Ministro Garcia Vieira, inicia seu voto trazendo de pronto sua interpretação do art. $6^{\circ}$ da Lei das Eleições. Para ele, a exigência constitucional de que os partidos políticos tenham caráter nacional ${ }^{244}$.

Garcia Vieira ressalta que a Constituição não permite que os partidos tenham caráter estadual ou municipal. Se fosse permitido ao partido coligar-se nos Estados com uma agremiação adversária na eleição nacional, a exigência constitucional em questão seria desrespeitada. Seu argumento resume-se neste trecho a seguir:

"Não podemos nos esquecer de que, como o legislador constitucional exige (art. 17, I) tenham os partidos políticos caráter nacional, e não estaduais ou municipais e isso ocorreria se permitíssemos que um partido (A), após celebrar coligação para a eleição de presidente da República com outros partidos (B, C e D) e, ao mesmo tempo, celebrasse coligação com terceiros partidos (E,

\footnotetext{
244 "Art. 17. É livre a criação, fusão, incorporação e extinção de partidos políticos, resguardados a soberania nacional, o regime democrático, o pluripartidarismo, os direitos fundamentais da pessoa humana e observados os seguintes preceitos:

I - caráter nacional".
} 
F e G) que também possuem candidatos a presidente da República. É claro que os candidatos a presidente podem ser diversos e, então, ocorreria o absurdo de termos uma coligação com diversos candidatos a presidente da República ${ }^{245}$ ".

Foi o único argumento trazido pelo Relator Garcia Vieira para responder a consulta de forma negativa.

Nelson Jobim também se posiciona para responder negativamente a consulta. Para o então Presidente do TSE, O caráter nacional dos partidos políticos poderia ser afetado se não houvesse a obrigatoriedade legal pela verticalização das coligações partidárias.

Jobim faz densa análise histórica da previsão normativa do caráter nacional. Nela, relembra Jobim que as previsões normativas anteriores à Constituição de 1988 (tanto em sede constitucional como em lei ordinárial dispunham sobre a necessidade de os partidos terem "âmbito nacional". Foi a Constituição de 1988 que mudou o termo para "caráter nacional".

A Lei dos Partidos Políticos (Lei n. $9.095 / 1995$ - LPP) traz, em seu art. 50246, a exigência de que a "ação do partido" tenha "caráter nacional". Reconhece Jobim que a previsão, na LPP, do $\$ 1^{\circ}$ do art. $7^{\circ}$ limita-se apenas à demonstração de caráter nacional pelo partido político no momento de registrar-se no Tribunal Superior Eleitoral.

${ }^{245}$ Cta. n. 715/DF, Rel. Min. Garcia Vieira, Resolução n. 21.002, j. 26.02 .2002 .

246 "Art. $5^{\circ}$ A ação do partido tem caráter nacional e é exercida de acordo com seu estatuto e programa, sem subordinação a entidades ou governos estrangeiros". 
Para Jobim, no entanto, a exigência constitucional e legal de "ação de caráter nacional" impede a formação de coligações estaduais "assimétricas com a decisão nacional", uma vez que isto violaria o caráter nacional das agremiações partidárias.

Destaca o então Presidente da Corte Eleitoral que a previsão constitucional em questão diz respeito à "luta contra vícios regionalistas que vêm do início da República". Define, por fim, que a exigência de caráter nacional tem um alvo, qual seja, fazerem os partidos "servirem aos interesses da nação e do eleitorado, e não, exclusivamente, aos interesses e conveniências eleitorais de seus integrantes ${ }^{247 "}$.

A Ministra Ellen Gracie também entendeu que o caráter nacional dos partidos políticos seria violado se não houvesse a verticalização. Para Gracie, a ausência da obrigatoriedade de os partidos, ao se coligarem, preservarem a coerência da aliança geraria situações de "bicefalia, ou, se preferirem, de esquizofrenia partidária, no nível estadual". Segue o raciocínio, no que toca ao caráter nacional dos partidos, ao afirmar que o possível desrespeito "levariam a indesejáveis dissidências regionais em relação aos partidos ${ }^{248 \prime \prime}$.

Os outros dois Ministros favoráveis ao advento da verticalização posicionaram-se com outros argumentos a serem estudados adiante.

247 Cta. n. 715/DF, Rel. Min. Garcia Vieira, Resolução n. 21.002, j. 26.02.2002, Voto da Ministro Nelson Jobim.

${ }^{248}$ Cta. n. 715/DF, Rel. Min. Garcia Vieira, Resolução n. 21.002, j. 26.02.2002, Voto da Ministra Ellen Gracie. 
No que toca ao primeiro argumento ora em debate, devemos discordar da posição majoritária da Corte neste julgamento. Primeiramente, devemos deixar nítido que a Constituição realmente previu o caráter nacional dos partidos, mas, ao mesmo tempo, não dispôs sobre os critérios a serem observados para o respeito a este ditame. Caberia, neste caso, ao legislador ordinário definir estes critérios.

A doutrina sempre se posicionou no sentido de que esta exigência constitucional se refere à proibição de que existam partidos regionais no Brasil, como ocorria no período da República Velha (1889-1930). Nesse sentido, Orides Mezzaroba afirma que

"com a imposição do princípio do caráter nacional buscouse, fundamentalmente, impedir a formação de partidos com simples programas regionais ou locais, como eram, por exemplo, as organizações da primeira República brasileira ${ }^{249 "}$.

Cláudio Mendonça Braga pensa da mesma forma. A exigência de caráter nacional, segundo Braga, deve ser sopesada com o princípio federativo. Nesse sentido, in verbis:

“O princípio do caráter nacional dos partidos políticos e o princípio federativo devem ser sopesados, a fim de que possam ser maximizados, ou seja, realizados na maior medida possível. Dessa maneira, levando-se em conta a previsão constitucional e a efetiva implementação de um Estado federal no Brasil, aliada à consagração do princípio da liberdade partidária, chega-se à conclusão que é inevitável um certo grau de regionalização dos partidos políticos e do sistema partidário ${ }^{250}$.

\footnotetext{
249 MEZZAROBA, Orides. Partidos políticos: princípios e garantias constitucionais. Lei 9.096/95. Anotações jurisprudenciais. Curitiba: Juruá, 2008, p. 25. Corrobora com este posicionamento José Bispo Sobrinho, ao asseverar que "não obstante o partido político se constitua de uma parcela do povo, representada por pessoas unidas por um ideal político, isto não siginifca que a atuação partidária se restrinja a uma dada área territorial do País, ou seja, a uma região apenas". (In: Comentários à lei orgânica dos partidos políticos. Brasília: Brasília Juridica, 1996, p. 28.

250 BRAGA, Cláudio Mendonça. O caráter nacional dos partidos políticos na federação brasileira. Dissertação de Mestrado defendida na Faculdade de Direito da Universidade de São Paulo, 2009, p. 134.
} 
Ademais, ao verificar a legislação ordinária sobre o tema, percebemos que o tema é tratado três vezes na Lei dos Partidos Políticos: nos arts. $5^{\circ} ; 7^{\circ}$, $\$ 1^{\circ}$ e no 13. Como o próprio Ministro Nelson Jobim reconheceu em seu voto, $0 \$ 1^{\circ}$ do art. $7^{\circ}$ trata da comprovação, pelo partido político, de seu caráter nacional apenas no momento de seu registro no TSE. Ademais, o art. 13 da LPP foi declarado inconstitucional pelo STF em 2006, não nos servindo para nossa análise no momento.

Assim, a interpretação do art. $5^{\circ}$ da LPP pode nos responder se há mesmo a necessidade de o partido respeitar a previsão constitucional de "caráter nacional" ao celebrar coligações. No nosso entendimento, o texto do art. $5^{\circ}$ é nítido no sentido de que a previsão de "ação do partido tem caráter nacional" se refere à atividade partidária sem qualquer subordinação ou mesmo vínculo financeiro com entidade ou governo estrangeiro. A leitura da parte final é conclusiva para esse entendimento.

Dessa forma, entendemos que a análise dos arts. 17, I, da Constituição; $5^{\circ}$ e $7^{\circ}, \$ 1^{\circ}$, ambos da Lei dos Partidos Políticos nos permite dizer que o regime de coligações partidárias não se submete à previsão constitucional e infraconstitucional de obrigatoriedade de os partidos políticos terem caráter nacional.

\subsubsection{Assimetria das Coligações}

Os Ministros Nelson Jobim e Ellen Gracie enfatizaram que a possibilidade de coligações partidárias nas quais partidos adversários nas eleições presidenciais 
serem coligados em eleições estaduais tornaria o quadro partidário nas eleições caótico.

O Presidente do TSE na ocasião iniciou seu voto demonstrando a gama matemática de possibilidades de coligações diferentes nas vinte e seis circunscrições estaduais e na circunscrição distrital em jogo nas eleições de 2002. Somado ao fato de participarem do pleito trinta partidos, enfatiza Jobim, a celebração de inúmeras coligações diferentes no pleito de 2002 seria "o problema suscitado pela consulta $251 "$.

A possível explosão do número de coligações assimétricas, espécie de cerne da questão para os defensores da verticalização, trouxe à baila o segundo argumento decisivo para o advento do princípio da coerência: a noção de "parâmetro inafastável" combinada com a teoria dos conjuntos circunscricionais.

\subsubsection{Conceito de "parâmetro inafastável" e a Teoria dos Conjuntos Circunscricionais}

o conceito já foi abordado no item 4.2.2 supra, em sede de julgamento da Consulta n. 382. Na oportunidade, o Ministro Néri da Silveira determinou que o art. $6^{\circ}$ da Lei das Eleições adotou referido princípio, no sentido de que deve ser mantido "fechado o círculo partidário que ampara a eleição majoritária252".

De tal modo, os partidos que participam de uma coligação majoritária (eleição para Governador e

251 Cta. n. 715/DF, Rel. Min. Garcia Vieira, Resolução n. 21.002, j. 26.02.2002. Voto do Min. Nelson Jobim.

${ }^{252}$ Cta. n. 382/DF, Rel. Min. Néri da Silveira. Resolução n. 20.126, de 12 de março de 1998 . 
Senador) terão total liberdade para exercerem seu interesse próprio em celebrar ou não coligações nas eleições proporcionais (deputado federal e deputado estadual)entre eles, não havendo a possibilidade de se coligarem com partidos que façam parte de outra coligação dentro da circunscrição.

Assim, numa coligação entre os partidos ABC, $\mathrm{DEF}$ e GHI em uma eleição majoritária, na eleição proporcional dentro daquela circunscrição podem esses partidos não se coligarem, ou formarem qualquer combinação entre eles. Entretanto, não podem se coligar com partidos que apresentem outros candidatos na eleição majoritária.

Foi o Ministro Nelson Jobim quem rememorou este argumento. Para ele, 0 art. $6^{\circ}$ vedou as coligações que apresentassem assimetria entre a coligação majoritária estadual e as coligações proporcionais. o trecho seguinte resume seu pensamento:

"A coligação para as eleições majoritárias se constitui na MOLDURA dentro da qual partidos, integrantes da coligação majoritária, poderão administrar as suas conveniências para as eleições proporcionais.

Combinações as mais diversas, inclusive a disputa isolada de um dos partidos, para as eleições proporcionais, são admitidas, desde que respeitada a MOLDURA decorrente da coligação para as eleições majoritárias.

Chamo de MOLDURA.

NÉRI chamou de PARÂMETRO INAFASTÁVEL ${ }^{253}$,

Reconhecemos que a lei prevê a propalada "moldura". Mas o "parâmetro inafastável" deve ser respeitado, desde que dentro da mesma circunscrição. Para Jobim, portanto, "a questão é saber se parâmetro inafastável é, ou não, predicado da coligação majoritária

253 Cta. n. 715/DF, Rel. Min. Garcia Vieira, Resolução n. 21.002, j. 26.02.2002. Voto do Min. Nelson Jobim. 
nacional em relação às coligações majoritárias e

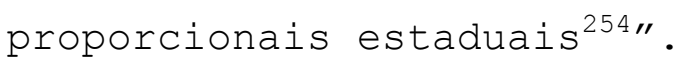

O texto do art. $6^{\circ}$ da Lei das Eleições traz determinação sobre a celebração de coligação majoritária e proporcional "dentro da mesma circunscrição". No caso das eleições gerais, há duas circunscrições em jogo: a nacional e as estaduais, pelo fato de as eleições serem simultâneas.

Jobim segue seu raciocínio dizendo que as quatro eleições em questão (Presidente da República, Governador, Senador, Deputado Federal e Deputado Estadual) não são vinculadas, ou seja, o cidadão pode votar em quem quiser, em candidatos de partidos ou coligações diversas. A proibição afetada pela "moldura", portanto, não se dirige ao eleitor.

De tal modo, o Presidente do TSE entende que a proibição prevista no art. $6^{\circ}$ da Lei das Eleições é dirigida às "coligações híbridas" na relação entre circunscrições nacional e estadual, uma vez que "como é evidente, a circunscrição nacional contém a estadual, como esta contém a circunscrição municipal ${ }^{255 \prime}$.

Para justificar essa análise, Jobim traz à tona questão de inelegibilidade. O \$ $7^{\circ}$ do art. 14 prevê que há inelegibilidade do cônjuge e de parente consanguíneo ou afim, até o segundo grau ou por adoção, do Presidente da República, do Governador, de Prefeito ou de quem os haja

${ }^{254}$ Cta. n. 715/DF, Rel. Min. Garcia Vieira, Resolução n. 21.002, j. 26.02.2002. Voto do Min. Nelson Jobim.

${ }^{255}$ Cta. n. 715/DF, Rel. Min. Garcia Vieira, Resolução n. 21.002, j. 26.02.2002. Voto do Min. Nelson Jobim. 
substituído dentro dos seis meses anteriores ao pleito no território de jurisdição do titular.

Nessa seara, o TSE e O STF concordaram em declarar inelegível cunhada de governador quando concorre para cargo eletivo de Município situado dentro do Estado. Assim, Jobim conclui, in verbis:

"Ou seja, a UNIÃO inclui os ESTADOS e o DISTRITO FEDERAL, e os ESTADOS, os MUNICÍPIOS de seu território.

É a teoria dos conjuntos, em que as circunscrições estaduais e municipal são um sub conjunto da circunscrição nacional ${ }^{256}$ ".

O Ministro Fernando Neves encampou a argumentação trazida por Nelson Jobim. Afirma Neves que "as eleições estaduais (governadores, senadores, deputados) se realizam dentro da circunscrição da eleição presidencial, que é o País $257 "$. No mesmo sentido, manifesta-se a Ministra Ellen Gracie.

Defendemos opinião diferente. A crítica à teoria dos conjuntos circunscricionais e ao mau uso do conceito de parâmetro inafastável será realizada no momento em que formos analisar os argumentos contrários à verticalização neste ponto específico (item 4.3.2.1 infra).

\subsubsection{Incoerência no Horário Eleitoral Gratuito}

O Ministro Luiz Carlos Madeira, ao votar pela resposta negativa à consulta, foi o único a manifestar-se sobre a possível incoerência no horário eleitoral gratuito caso O TSE permitisse a realização de coligações "assimétricas".

256 Cta. n. 715/DF, Rel. Min. Garcia Vieira, Resolução n. 21.002 , j. 26.02.2002. Voto do Min. Nelson Jobim.

257 Cta. n. 715/DF, Rel. Min. Garcia Vieira, Resolução n. 21.002, j. 26.02.2002. Voto do Min. Fernando Neves. 
Madeira remete à previsão constitucional sobre o acesso gratuito ao rádio e à televisão para os partidos políticos (art. $17, \$ 3^{\circ}$ ). Sua segunda remissão dirige-se aos dispositivos da Lei das Eleições que tratam da propaganda eleitoral. Neles, estão determinados os critérios legais para a divisão do tempo de propaganda eleitoral entre todos os partidos.

Assim, o Ministro Madeira traz à baila o art. 54 da Lei das Eleições, que determina a proibição de participação na propaganda eleitoral de qualquer pessoa não filiada à agremiação partidária participante daquela coligação. Desse modo, exemplificaremos o pensamento de Madeira para anuir com o advento da verticalização.

A primeira coligação presidencial tem os partidos ABC, DEF e GHI; a segunda foi celebrada pelos partidos XYZ, PQR e TUV. Desse modo, se permitidas as coligações "assimétricas" ABC/DEF/PQR e GHI/XYZ/TUV nas eleições estaduais, o candidato presidencial de cada coligação pode participar da propaganda eleitoral das duas coligações estaduais.

A nosso ver, essa argumentação não deve prosperar porque a previsão constitucional de livre acesso dos partidos ao horário gratuito e ao Fundo Partidário (art. 17, $\$ 3^{\circ}, \mathrm{CRFB}$ ) se refere horário partidário gratuito, e não ao horário eleitoral gratuito.

Todas as disposições do art. 17 da Constituição estão regulamentadas pela Lei dos Partidos Políticos (Lei n. 9.096/1995), e não pela Lei das Eleições (Lei n. 9.504/1997). Nesse sentido, a LPP prevê, nos arts. 
45 a 48, as regras para a divisão do horário partidário, ou seja, aquele em que os partidos exibem seu ideário e suas propostas na televisão e no rádio de forma gratuita fora do período eleitoral. Assim sendo, invocar o $\$ 3^{\circ}$ do art. 17 da Constituição para o caso não tem fundamentação, uma vez que ele trata do horário partidário em período não eleitoral, e não sobre propaganda eleitoral.

\subsubsection{Possíveis Benesses da Verticalização ao Sistema Politico-Eleitoral Brasileiro}

Por fim, foram levantadas nos votos vencedores as possíveis benesses que 0 advento da verticalização traria ao sistema político-eleitoral brasileiro como um todo.

Nelson Jobim, primeiramente, destaca que a verticalização serviria para o fortalecimento dos partidos. Para ele, a possibilidade até então existente de celebração de coligações assimétricas reforça a "prevalência dos interesses estaduais na ação política", o que decorre na "irrelevância dos partidos nacionais". A assimetria nas coligações resulta na existência de "vinte e sete grupos de liderança partidária", dificultando sobremaneira o fortalecimento dos partidos políticos.

Ellen Gracie também defende a verticalização numa postura consequencialista. Para ela, o advento da verticalização aponta

"no sentido da coerência partidária e no da consistência ideológica das agremiações e das alianças que se venham a formar, com inegável aperfeiçoamento do sistema político-partidário ${ }^{258 "}$.

258 Cta. n. 715/DF, Rel. Min. Garcia Vieira, Resolução n. 21.002, j. 26.02.2002. Voto da Min. Ellen Gracie. 
As críticas a serem feitas quanto às possíveis benesses apontadas por Jobim e Gracie serão realizadas no item 4.12 infra, que tratará dos presumíveis prejuízos que a verticalização poderia ter causado.

\subsubsection{Argumentos contra a verticalização}

Neste subitem, passaremos à análise dos
argumentos levantados nos votos contrários à
verticalização. Este subitem, da mesma forma que o
anterior, trará explanação em separado de cada argumento
levantado nos dois votos vencidos por ocasião o julgamento
da Consulta n. 715 .

\subsubsection{Conceito de Circunscrição Eleitoral}

O Ministro Sepúlveda Pertence inicia seu voto contrário ao posicionamento do Relator, Min. Garcia Vieira, demonstrando sua preocupação em determinar que o TSE, no exercício de suas funções consultiva e regulamentar, não pode ultrapassar as barreiras legais e constitucionais.

Seu voto tem como principal argumento, no entanto, o conceito de circunscrição eleitoral. Para tanto, traz à baila o texto do art. 86 do Código Eleitoral ${ }^{259}$.

Assim, segundo Pertence, o Código Eleitoral prevê três circunscrições diferentes: a nacional, a estadual e a municipal. O fato de as eleições gerais reunirem as eleições nacional e estadual, segundo o Ministro, não passa de mera circunstância acidental que

259 "Art. 86. Nas eleições presidenciais, a circunscrição será o país, nas eleições federais e estaduais, o Estado; e nas municipais, o respectivo Município". 
"não afeta a recíproca independência jurídica das respectivas circunscrições ${ }^{260 "}$.

Assim, só há um pleito sob a circunscrição nacional: a eleição à Presidência da República. Se a verticalização preponderar, segundo Pertence, a Lei das Eleições deveria prever período separado para as convenções partidárias no âmbito nacional e estadual. Esta, pela lógica da verticalização, deveria esperar as diretrizes firmadas na convenção partidária nacional. A Lei n. 9.504/97, no entanto, não prevê tal diferença.

Além disso, Pertence rebate a argumentação trazida por Nelson Jobim para justificar a teoria dos conjuntos circunscricionais pela leitura do $\$ 7^{\circ}$ do art. 14 da Constituição. Concordamos com a opinião do Ministro Sepúlveda Pertence.

Uma rápida análise demonstra o argumento de Pertence: o $\$ 7^{\circ}$ do art. 14 da CRFB utiliza o termo "território de jurisdição", enquanto o art. $6^{\circ}$ da Lei das Eleições fala em "circunscrição eleitoral", conforme comando do art. 86 do Código Eleitoral. Assim, no território de um Município qualquer, há três ordens federativas em jogo: a União, o Estado e o Município. São ordens distintas numa Federação.

Territorialmente, segundo Pertence, é evidente que a circunscrição nacional contém a estadual. Juridicamente, porém, esse fenômeno trazido pelo voto do

${ }^{260}$ Cta. n. 715/DF, Rel. Min. Garcia Vieira, Resolução n. 21.002, j. 26.02.2002, Voto do Min. Sepúlveda Pertence. 
Min. Jobim não ocorre, conforme pode-se depreender do trecho citado a seguir:

"Similarmente, na estrutura do sistema eleitoral, ninguém nega que, territorialmente, a circunscrição das eleições presidenciais - o País - compreende a das demais eleições para o Congresso Nacional e para os mandatos eletivos estaduais - que é o Estado -, assim como essa corresponde à soma das circunscrições municipais respectivas.

$\mathrm{O}$ que, entretanto, não desmente a recíproca impermeabilidade jurídica das três circunscrições: malgrado sejam parcialmente superpostos os respectivos territórios, demarca cada uma das circunscrições o âmbito não só espacial, mas também do colégio eleitoral de pleitos distintos ${ }^{261 "}$.

Encerra Pertence seu voto neste argumento ao dizer que se O TSE aplicar a teoria dos conjuntos circunscricionais, a expressão da lei "dentro da mesma circunscrição" perde todo o sentido.

\subsubsection{Princípio da Anterioridade Eleitoral}

- Ministro Sepúlveda Pertence invocou o desrespeito ao art. 16 da Constituição em seu voto contrário ao advento da verticalização.

Nesse sentido, alerta o Ministro Pertence por meio de exemplo, que, em 1998, O PT e o PSDB, adversários na eleição presidencial, formaram coligação que elegeu o governador do Acre. Nesse ínterim, Pertence ressalta que não houve alteração na Lei das Eleições sobre as normas de coligação partidária. O advento da verticalização naquela oportunidade, segundo Pertence, feriria, por conseguinte, a anterioridade eleitoral.

O Ministro Sálvio de Figueiredo Teixeira, no mesmo sentido, defendeu que o espírito do art. 16 da

261 Cta. n. 715/DF, Rel. Min. Garcia Vieira, Resolução n. 21.002, j. 26.02.2002, Voto do Min. Sepúlveda Pertence. 
Constituição estava sendo vilipendiado com o advento intempestivo da verticalização das coligações partidárias. Seus ensinamentos podem ser resumidos com a exposição do trecho a seguir:

"Primeiro - que o processo eleitoral de 2002, a sete meses das eleições, já está definitivamente em curso, com candidaturas visualizadas nos Estados e no País, presentes diuturnamente na mídia, nos institutos de pesquisa, no Congresso e na sociedade, com composições bem adiantadas, algumas delas celebradas e divulgadas, sendo manifesto que o prejuízo, o tumulto e a surpresa que o referido art. 16 da Constituição busca evitar, se farão presentes com essa mudança de rumos já no curso da competição, alterando-lhe as regras, sabido mais que a consulta de que se trata há meses se encontrava protocolada, somente agora vindo à apreciação e decisão ${ }^{262 \%}$.

A nosso ver, houve desrespeito à

anterioridade eleitoral na decisão que originou a verticalização. Se a lei que alterar o processo eleitoral for aprovada no período de menos de um ano antes da eleição só pode gerar efeitos após um ano da promulgação, decisão exarada pelo TSE por meio de sua função regulamentar também se insere nesse contexto constitucional. Trataremos com maior profundidade sobre o tema no item 4.9 .1 infra.

\subsubsection{Autonomia constitucional dos Partidos Politicos}

O Ministro Sepúlveda Pertence ressalta em seu voto que a verticalização das coligações partidárias atinge o princípio da autonomia partidária. A seu ver, a alegação de que os partidos devem ter "caráter nacional" não prevalece na hipótese em comento.

Primeiramente, a previsão constitucional da obrigatoriedade de os partidos terem caráter nacional se refere apenas à proscrição da criação de partidos políticos

262 Cta. n. 715/DF, Rel. Min. Garcia Vieira, Resolução n. 21.002 , j. 26.02.2002, Voto do Min. Sálvio de Figueiredo Teixeira. 
de caráter regional ou local, mesma posição defendida por nós no subitem 4.3.1.1 supra.

Ademais, a Constituição garante a autonomia partidária para a definição de sua estrutura interna, organização e funcionamento (art. 17, \$ $1^{\circ}, \mathrm{CRFB}$ ). Nas palavras de Sepúlveda Pertence, a autonomia partidária constitucional

“impede à própria lei e, com mais razão, à Justiça Eleitoral, que dite coerência ortodoxa das Seções estaduais à composição da coligação para as eleições presidenciais em que se haja engajado a legenda ${ }^{263 "}$.

No mesmo sentido, traz o Ministro Sepúlveda Pertence o conteúdo do $\$ 2^{\circ}$ do art. $7^{\circ}$ da Lei das Eleições. Este texto refere-se à possibilidade de órgão superior da organização interna partidária anular deliberação de órgão inferior quando este deliberar sobre coligações em desrespeito às diretrizes "legitimamente estabelecidas pela convenção nacional".

Ora, se a Lei das Eleições prevê que pode, numa eleição geral, o Diretório Nacional anular deliberação de um Diretório Estadual que decidiu por coligar-se contrariamente à diretriz estabelecida em convenção nacional, como se pode retirar do art. $6^{\circ}$ da mesma lei interpretação de que as coligações nas eleições estaduais devem ser "simétricas" às alianças celebradas na eleição presidencial?

Devemos concordar com os argumentos trazidos à baila pelos Ministros Sepúlveda Pertence e Sálvio de Figueiredo Teixeira. Determinar como base da vigência da verticalização a obrigação constitucional de

${ }^{263}$ Cta. n. 715/DF, Rel. Min. Garcia Vieira, Resolução n. 21.002, j. 26.02.2002, Voto do Min. Sepúlveda Pertence. 
caráter nacional dos partidos carece de sentido sob uma análise da evolução histórica do instituto, bem como diante dos ditames dos arts. $5^{\circ}$ e $7^{\circ}$ da Lei dos Partidos Políticos. No mais, a Constituição garante aos partidos autonomia para definir sua organização, estrutura interna e funcionamento, dispositivo que a obrigatoriedade de verticalização nas coligações claramente prejudica.

Ademais, o advento da verticalização claramente violou o princípio constitucional da anterioridade eleitoral. Se, nas eleições de 1998, O PT pôde aliar-se ao PSDB nos Estados, mesmo sendo adversários na corrida presidencial, a decisão do TSE que resultou na verticalização mudou o processo eleitoral para as eleições de 2002 (no exemplo em comento, a verticalização veda a coligação entre PT e PSDB em qualquer estadol a menos de sete meses para a realização do pleito.

Por fim, a vencedora teoria dos conjuntos circunscricionais carece de fundamentação legal. O art. 86 do Código Eleitoral é de clareza solar ao determinar que as eleições no Brasil têm três circunscrições diferentes. Ademais, o $\$ 7^{\circ}$ do art. 14 da Constituição não faz qualquer referência a circunscrição eleitoral, mas sim a "território de jurisdição", dois institutos distintos.

\subsection{Consultas formuladas ao Tribunal Superior Eleitoral no ano de 2002}

Este item traz todas as demais decisões

exaradas pelo TSE no ano de 2002 no que tange à verticalização. Todas elas foram tomadas no dia 26 de março de 2002, ou seja, no bojo da necessidade de o Tribunal Superior Eleitoral expedir instruções para regulamentar 
todo o processo eleitoral a ser iniciado em junho daquele ano e encerrado com a votação nas urnas em segundo turno, no final de outubro.

- fato é que diante da Resolução n. 21.002, houve o surgimento de novas dúvidas. Várias novas consultas foram apresentadas e, consequentemente, o TSE teve de respondê-las rapidamente. Veremos que diante do choque causado no corpo político brasileiro com a nova interpretação que culminou na verticalização, O TSE respondeu a cinco consultas no sentido de abrandar as regras então estabelecidas na Consulta n. 715/DF.

\subsection{1 "Afrouxamento" da Verticalização: Resoluções TSE n. $21.045,21.046,21.047,21.048$ e 21.049}

Para dirimir as novas dúvidas surgidas com o advento da verticalização das coligações partidárias, houve a apresentação de cinco novas consultas. Neste subitem, cada uma delas será analisada para que possamos entender com maior profundidade todo o contexto jurídico da verticalização nas eleições de 2002.

A primeira consulta analisada foi a $n$. 758/DF, apresentada pelo Diretório Nacional do PPB (Partido Progressista Brasileiro, hoje PP - Partido Progressista). O intuito principal da consulta do PPB ao TSE era saber como um partido que não participasse de qualquer coligação nas eleições presidenciais e também não apresentasse candidatura presidencial poderia agir nas eleições distrital e estaduais. Segue, in verbis, a consulta do PPB:

"Supondo-se 2 (duas) coligações à presidência da República, $\underline{\mathbf{A}+\mathbf{B}+\mathbf{C}}$ e $\underline{\mathbf{D}+\mathbf{E}+\mathbf{F}}$, indaga-se:

1. No estado ou no Distrito Federal, o partido $\mathbf{X}$, que não lançou candidato e nem se compôs com qualquer coligação à 
presidência da República, poderá compor-se, para a eleição de governador, com uma das duas coligações acima?

2. No estado ou no Distrito Federal, esse partido $\mathbf{X}$ poderá compor-se com parte de uma das coligações acima, para a eleição de governador?

3. O partido $\mathbf{X}$ poderá se compor também, do mesmo modo, para a eleição de senador?

4. Uma coligação $\mathbf{A + B}+\mathbf{C}+\mathbf{D}$, por exemplo, para a presidência da República, poderá, no Estado ou no Distrito Federal, fracionar-se em $\underline{\mathbf{A}+\mathbf{B}}$ e $\underline{\mathbf{C}+\mathbf{D}}$, lançando dois candidatos a governador?

5. Poderá, na mesma situação acima, lançar também candidatos a senador?

6. Em qualquer das hipóteses de 1 a 5, poderá, ainda, compor-se com os partidos 'solteiros', isto é, sem compromisso com a candidatura à presidência da República?

7. Em qualquer das hipóteses 1 a 6 , as coligações, fracionadas ou não, poderão compor-se, como lhes aprouver, para a eleição de deputados federais e/ou deputados estaduais ou distritais?

8. Se o partido $\mathbf{X}$ não lançar candidato à presidência da República, poderá, nos estados ou no Distrito Federal coligar-se com outros que estejam na mesma situação?

9. Se respondida afirmativamente a pergunta $n^{\circ} 8$, a coligação que surgir dessa composição, no estado ou no Distrito Federal, perderá seus horários no rádio e na televisão, destinados à propaganda para presidente da República, às terças-feiras, quintasfeiras e sábados? ${ }^{264} "$ (grifos e destaques no original).

O Ministro Relator Fernando Neves inicia seu voto com uma questão preliminar ex officio. Relembra o magistrado que havia ainda no Supremo Tribunal Federal ações diretas de inconstitucionalidade pendentes de julgamento (vide item 4.9 infra) ${ }^{265}$.

\footnotetext{
${ }^{264}$ Cta. n. 758/DF, Rel. Min. Fernando Neves, Resolução n. 21.045, de 26 de março de 2002 .

265 O Ministro Fernando Neves não escapou de externar sua opinião quanto à viabilidade das ações diretas de inconstitucionalidade, aproveitando - ensejo para defender O TSE não só na interpretação sobre a verticalização das coligações partidárias, mas também no exercício de sua função consultiva: "Não me parece que tenham razão, conforme tentei demonstrar nas informações prestadas ao supremo Tribunal Federal. Não estamos legislando, nem inovando, mas apenas interpretando a legislação existente sobre o tema, como sempre fez este Tribunal, quando provocado". Por fim, o Min. Fernando Neves também rebate a alegação contida nas ações diretas quanto ao desrespeito, por parte do TSE, do princípio da anterioridade eleitoral previsto no art. 16 da CRFB: "Penso que podemos explicitar nosso entendimento sobre as coligações até a data estabelecida para o começo do período destinado à realização de convenções para decidir sobre
} 
Fernando Neves avalia que a consulta deve ser respondida da mesma forma, "pois é um direito do requerente formulá-la e uma obrigação deste Tribunal responder", ressaltando que sempre há a conveniência de o TSE dirimir as dúvidas surgidas "O quanto antes", para, assim, "evitar discussões em casos concretos, com graves

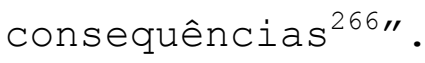

No mérito, o Min. Neves novamente sustenta que a verticalização deve subsistir. O partido coligado na eleição presidencial não pode se coligar com seus adversários nas eleições estaduais, uma vez que "a circunscrição estadual está contida na circunscrição federal". Para os partidos que não participam da eleição presidencial, no entanto, há liberdade de celebração de coligações nos estados e no Distrito Federal, já que ele não tem adversários na eleição presidencial, ou seja, não há "superposição de circunscrições nem há possibilidade de a coligação estadual ser composta por partidos adversários na eleição nacional $267 "$. Sua posição resume-se neste trecho a seguir:

"Como afirmei no voto que proferi na Consulta $\mathrm{n}^{\mathrm{0}} 715$, o espírito da lei, do art. $6^{\circ}$ da Lei $n^{\circ} 9.504$, de 1997, parece ser, a meu ver, o de impedir que adversários na eleição presidencial sejam aliados na eleição estadual, do mesmo modo que partidos

coligações e escolher candidatos às eleições deste ano". Para maiores informações sobre esta argumentação, vide item 4.9 infra.

${ }^{266}$ Cta. n. 758/DF, Rel. Min. Fernando Neves, Resolução n. 21.045, de 26 de março de 2002 .

267 Nesse sentido, o Min. Fernando Neves ressalta que os partidos que fazem parte da eleição presidencial também têm certa liberdade para celebrar coligações, podendo fazer combinações coligativas nas eleições estaduais entre as agremiações que não são suas adversárias na eleição nacional: "Por isso, não considero que seja vedado pela lei eleitoral que determinado partido político que esteja participando da eleição presidencial coligado com outros dois concorra na eleição estadual com esses mesmos dois (ou apenas um deles, ou isoladamente) e, ainda, aliado a um outro partido que não esteja disputando a eleição presidencial". Cta. n. 758/DF, Rel. Min. Fernando Neves, Resoluçãon. 21.045, de 26 de março de 2002 . 
adversários, nas eleições para governador ou senador, não podem ser aliados nas eleições proporcionais ${ }^{268,}$.

\section{Segue o raciocínio:}

"Todas essas conclusões decorrem da leitura que faço do art. $6^{\circ}$ da Lei ${ }^{\circ} 9.504$, de 1997, cujo espírito, repito, é o de vedar que 'adversários em cima se unam embaixo', seguindo a ordem tradicionalmente estabelecida: (1) presidente da república, (2) governador ou senador, (3) deputados federais e deputados estaduais ou distritais.

Por fim, observo, desde que se admita, dentro desses três patamares, que os aliados podem se separar para concorrer isoladamente, penso que eles podem também se dividir para concorrer em grupos, respeitada a coligação superior. Observo, mais uma vez, o princípio fixado pelo Ministro Néri da Silveira na resposta à Consulta n $382^{269, "}$.

Fernando Neves assume essa liberdade
coligativa, mesmo sob a égide da verticalização, pode
causar "espanto ao eleitor". De fato, num regime imposto
pela interpretação do TSE de que o partido deve ser
coerente em suas coligações, não há nenhum sentido em haver
liberdade de coligações às agremiações partidárias que não
fazem parte da eleição presidencial.

Na verdade, a interpretação do TSE neste ponto abriu uma enorme brecha aos partidos políticos "incoerentes". A atenuação da verticalização neste ponto abriu a possibilidade de os partidos políticos terem a mesma liberdade coligativa que sempre tiveram nas eleições gerais desde, ao menos, a Constituição de 1988. Bastava, para tanto, não participar formalmente da eleição presidencial.

Ademais, se seguirmos 0 pensamento externado pelo Ministro Fernando Neves de que a circunscrição estadual faz parte da circunscrição nacional,

\footnotetext{
${ }^{268} \mathrm{Cta}$. n. 758/DF, Rel. Min. Fernando Neves, Resolução n. 21.045, de 26 de março de 2002 .

${ }^{269}$ Cta. n. 758/DF, Rel. Min. Fernando Neves, Resolução n. 21.045, de 26 de março de 2002 .
} 
- fato de o partido abdicar da participação na eleição presidencial obrigaria, da mesma forma, o respeito ao princípio da coerência nas coligações. Isso porque, se as circunscrições estaduais são, todas elas, parte de uma mesma circunscrição mais abrangente - a nacional - então, não podem ser consideradas diferentes. Para que houvesse uma linha mestra na formação das coligações de um partido sem candidatura nacional, bastava ser convocada uma convenção nacional do partido que teria como objetivo a decidir quais seriam as diretrizes adotadas na formação das coligações estaduais ${ }^{270}$.

No mesmo sentido, votou o Ministro Sepúlveda Pertence. Ao atestar que o voto do Ministro Fernando Neves faria com que uma nova categoria de partidos fosse criada (partidos "camarões" ou "mulas-sem-cabeça", uma vez que eles não participariam das eleições presidenciais), o Ministro vencido na decisão que impôs a verticalização, asseverou, primeiramente, sempre em nome do princípio da colegialidade com vistas à coerência normativa do TSE, que a questão apresentada na Consulta em voga deveria ter como parâmetro a interpretação do requisito constitucional do caráter nacional dos partidos políticos e da teoria dos conjuntos circunscricionais exarada pelo TSE quando da imposição da verticalização.

\footnotetext{
270 Data maxima venia, o Ministro Fernando Neves se contradisse em sua teoria dos conjuntos circunscricionais (vide subitem 4.3.1.3 supra), ao atestar o seguinte: "Como será possível que uma agremiação partidária apoie um programa em um estado e outro, antagônico, em outro estado? Isso não contribui para o fortalecimento dos partidos, nem da democracia. Todavia, não encontro na legislação eleitoral, especialmente no capítulo da Lei n²9.504, de 1997, que trata das coligações, dispositivo que impeça essa manifesta incoerência. Se as circunscrições não são as mesmas, não vejo como possa incidir norma legal quem impede um mesmo partido de participar de coligações diferentes, dentro de uma mesma circunscrição". Cta. n. 758/DF, Rel. Min. Fernando Neves, Resolução n. 21.045, de 26 de março de 2002.
} 
Sob esta ótica, Pertence afirma que não via como conciliar a premência do caráter nacional dos partidos e a teoria dos conjuntos circunscricionais com o conteúdo do voto do Ministro Fernando Neves, qual seja, liberando os partidos que não participassem da eleição presidencial para celebrar coligações estaduais livremente, in verbis:

"Com efeito:

a) se - conforme o entendimento majoritário da Res./TSE 21.002, à qual, aqui e agora, me mantenho fiel -, na hipótese de eleições gerais, a eleição presidencial e as eleições estaduais se travam ambas numa só e 'mesma circunscrição', o País, e

b) se - conforme a Res./TSE 20.126, que todos nós reafirmamos -, 'na mesma circunscrição' para todas as eleições majoritárias simultâneas - isto é, para governador para senadores e também para presidente da República, segundo entendeu a maioria -, somente é admissível uma coligação, a conclusão para mim é inequívoca:

- coligados os partidos A, B e C para a eleição presidencial, para as eleições majoritárias em cada estado só lhes é permitido reproduzir a coligação nacional ou disputar isoladamente as duas ou aquela em que não seja possível a simetria;

- em qualquer hipótese, A, B, C, nem conjunta nem isoladamente, podem coligar-se com $\mathrm{D}$ - ainda que o último não tenha candidato a presidente da República -, a fim de concorrer no estado às eleições majoritárias ou proporcionais ${ }^{271 "}$.

Fernando Neves assevera que, na sua
opinião, a base constitucional da interpretação que
resultou na verticalização não está no inciso I do art. 17
da CRFB, pois a exigência de caráter nacional aos partidos
"não impõe uma uniformidade de atuação, mas exige uma
presença efetiva no território nacional", presença esta
demonstrada pela agremiação no momento do registro do
partido no TSE, por meio do "apoiamento de eleitores",
conforme art. $7^{\circ}, \$ 1^{\circ}$, da Lei dos Partidos políticos (Lei
n. 9.096/1995).

${ }^{271}$ Cta. n. 758/DF, Rel. Min. Fernando Neves, Resolução n. 21.045, de 26 de março de 2002. Voto do Min. Sepúlveda Pertence. 
Assim, O Ministro Relator respondeu a Consulta apresentada pelo Diretório Nacional do PPB da seguinte forma:

1. No item 1, positivamente. Há a possibilidade de o partido que não participar da eleição presidencial celebrar coligação com quaisquer outras agremiações, participantes ou não da eleição presidencial;

2. No item 2, positivamente. Partidos que formaram coligação visando à eleição presidencial quando se repartirem em algum estado podem receber, nessa nova coligação estadual, partido que não participou da eleição presidencial;

3. No item 3, positivamente. As mesmas regras devem ser aplicadas para as eleições senatoriais;

4. No item 4, positivamente. Coligações para a eleição presidencial podem se repartir no estados; os partidos coligados podem, em grupos ou sozinhos, apresentar candidatura ao governo do Estado;

5. No item 5, positivamente. Coligações para a eleição presidencial podem se repartir no estados; os partidos coligados podem, em grupos ou sozinhos, apresentar candidatura ao Senado;

6. No item 6, positivamente. Partidos fora da eleição presidencial podem se coligar com outros na mesma situação nas eleições estaduais ou distrital;

7. No item 7, negativamente. "Os partidos políticos que disputam, em coligação, eleições majoritárias não podem compor-se, como bem lhes aprouver, para a eleição de deputados federais e/ou deputados estaduais ou distritais; mas, podem dividir-se para disputar, em grupos ou isoladamente, as eleições proporcionais ${ }^{272 " ;}$

\footnotetext{
${ }^{272}$ Cta. n. 758/DF, Rel. Min. Fernando Neves, Resoluçãon. 21.045, de 26
} de março de 2002 . 
8. No item 8, positivamente. Partidos fora da eleição presidencial podem se coligar com outros na mesma situação nas eleições estaduais ou distrital;

9. No item 9, positivamente. Os partidos que não participarem da eleição presidencial não participarão do rateio do tempo de propaganda eleitoral gratuita no rádio e na televisão destinado à eleição presidencial.

Acompanharam o voto do Relator os seguintes Ministros: Nelson Jobim, Ellen Gracie, Sálvio de Figueiredo Teixeira, Barros Monteiro e Luiz Carlos Madeira.

A segunda consulta julgada no mesmo dia envolvendo a verticalização das coligações partidárias foi apresentada pelo senador Romero Jucá (PMDB/Roraima) ${ }^{273}$. O espírito desta consulta era o mesmo da anterior, qual seja, delimitar como os partidos, se isolados ou não participantes de coligação presidencial, poderiam agir nos Estados-membros e no Distrito Federal.

O Ministro Relator, Fernando Neves, indicou novamente que: (i) os partidos que estivessem fora da eleição presidencial poderiam celebrar coligações nas eleições estaduais com partidos que estivessem, isoladamente ou em coligação, concorrendo no pleito presidencial; (ii) os partidos que não estivessem participando da eleição presidencial não precisavam, necessariamente, disputar eleições nos Estados-membros e no Distrito Federal também isoladamente - havia liberdade para estes partidos celebrarem coligações com partidos na mesma

\footnotetext{
${ }^{273}$ Cta. n. 759/DF, Rel. Min. Fernando Neves, Resoluçãon. 21.046, de 26
} de março de 2002 . 
Acompanharam, do mesmo modo, o voto do Relator os seguintes Ministros: Nelson Jobim, Ellen Gracie, Sálvio de Figueiredo Teixeira, Barros Monteiro e Luiz Carlos Madeira.

A terceira consulta julgada foi apresentada pelos Diretórios Nacionais dos seguintes partidos: PGT, PHS, PSDC, PSL, PST, PT do B e PTN ${ }^{276}$. Seu teor era o mesmo das duas primeiras analisadas neste subitem.

O voto do Min. Relator, Fernando Neves, deixou neste momento mais evidente que nas eleições proporcionais, a liberdade coligativa é ainda maior, pois as agremiações partidárias políticos que participam de coligação para a eleição presidencial podem formar, entre elas: (i) coligações distintas para disputar as eleições proporcionais, "desde que não sejam adversários nas eleições de governador ou senador 277 "; (ii) disputar isoladamente as eleições proporcionais; (iii) reproduzie essa coligação presidencial apenas para a eleição de senador, quedando-se fora da eleição para governador.

Acompanharam, mais uma vez, o voto do Relator os seguintes Ministros: Nelson Jobim, Ellen Gracie, Sálvio de Figueiredo Teixeira, Barros Monteiro e Luiz Carlos Madeira. A divergência foi trazida no mesmo teor anterior pelo Min. Sepúlveda Pertence.

\footnotetext{
${ }^{276}$ Cta. n. 760/DF, Rel. Min. Fernando Neves, Resolução n. 21.047, de 26 de março de 2002 .

${ }^{277}$ Cta. n. 760/DF, Rel. Min. Fernando Neves, Resolução n. 21.047, de 26 de março de 2002 .
} 
A quarta consulta sobre as especificações da interpretação da verticalização das coligações partidárias foi apresentada pelo senador Geraldo Melo (PMDB/Rio Grande do Norte) ${ }^{278}$. O voto do Relator, Ministro Fernando Neves, deixou nítido nesta oportunidade que não há obrigação de os partidos ou coligações apresentar candidatos a todos os cargos em disputa.

A quinta e última consulta foi protocolizada pelo Diretório Nacional do Partido dos Trabalhadores ${ }^{279}$. Nesta consulta, o único item que ganhou maior evidência foi o fato, já respondido na consulta $n$. 382/DF (vide item 4.2.2 supra) que partidos adversários nas eleições majoritárias não podem se aliar nos pleitos proporcionais.

\subsection{Ações Diretas de Inconstitucionalidade n. 2.626 2.628}

A reação inicial ao advento da verticalização pelo TSE foi o ajuizamento de duas ações diretas de inconstitucionalidade no Supremo Tribunal Federal com o objetivo de extirpar do ordenamento jurídico a primazia do princípio da coerência nas coligações partidárias.

278 Cta. n. 762/DF, Rel. Min. Fernando Neves, Resolução n. 21.048, de 26 de março de 2002. Acompanharam, novamente, o voto do Relator os seguintes Ministros: Nelson Jobim, Ellen Gracie, Sálvio de Figueiredo Teixeira, Barros Monteiro e Luiz Carlos Madeira. A divergência foi trazida no mesmo teor anterior pelo Min. Sepúlveda Pertence.

${ }^{279}$ Cta. n. 766/DF, Rel. Min. Fernando Neves, Resolução n. 21.049, de 26 de março de 2002. Acompanharam, igualmente, o voto do Relator os seguintes Ministros: Nelson Jobim, Ellen Gracie, Sálvio de Figueiredo Teixeira, Barros Monteiro e Luiz Carlos Madeira. A divergência foi trazida no mesmo teor anterior pelo Min. Sepúlveda Pertence. 
Assim sendo, poucos dias depois, vários partidos políticos ${ }^{280}$, no exercício de sua prerrogativa constitucional (art. 103, VIII, CRFB), ajuizaram ação direta visando à declaração de inconstitucionalidade do $\$$ $1^{\circ}$ do art. $4^{\circ}$ da Resolução n. 20.993 do TSE ${ }^{281}$, que dispõe sobre a escolha e o registro dos candidatos nas eleições de 2002, que tem o seguinte texto:

"Art. $4^{\circ}$ É facultado aos partidos políticos, dentro da mesma circunscrição, celebrar coligações para eleição majoritária, para proporcional, ou para ambas, podendo, neste último caso, formarse mais de uma coligação para a eleição proporcional entre os partidos políticos que integram a coligação para o pleito majoritário (Lei $\mathrm{n}^{\circ} 9.504 / 97$, art. $6^{\circ}$, caput).

$\S 1^{\circ}$ Os partidos políticos que lançarem, isoladamente ou em coligação, candidato/a à eleição de presidente da República não poderão formar coligações para eleição de governador/a de estado ou do Distrito Federal, senador/a, deputado/a federal e deputado/a estadual ou distrital com partido político que tenha, isoladamente ou em aliança diversa, lançado candidato/a à eleição presidencial (Lei n ${ }^{\circ}$ 9.504/97, art. 6 $6^{\circ}$; Consulta n ${ }^{\circ} 715$, de 26.2.2002)".

As ações diretas de inconstitucionalidade foram julgadas conjuntamente pelo Pleno do STF em 18 de abril de 2002 e, por maioria, não foi conhecida ${ }^{282}$. Assim, a verticalização vigeu nas eleições de 2002.

\section{Neste item, trataremos da argumentação dispendida pelos Ministros do Supremo Tribunal Federal na oportunidade. Faremos também uma análise crítica dessa argumentação, diante de todos os tópicos já expostos sobre - tema neste trabalho. Para tanto, este item será dividido}

\footnotetext{
${ }^{280}$ A ADI n. 2.626/DF foi ajuizada pelo PC do B, PL, PT, PPS e PSB. Já a ADI n. 2.628/DF foi ajuizada pelo PFL.

281 Após o julgamento da Consulta n. 715, que resultou no advento da verticalização das coligações partidárias (Resolução n. 21.002), foi acrescida a regra prevista no $\$ 1^{\circ}$ do art. $4^{\circ}$ da Resolução n. 20.993, que tratava de todas as normas concernentes à escolha e registro de candidatos nas eleições de 2002. A inclusão da verticalização nesta norma foi o objeto das ações diretas de inconstitucionalidade ora em análise.

${ }^{282}$ ADI n. 2.626/DF, Rel. Min. Sydney Sanches, Rel. p/ Acórdão Min. Ellen Gracie, j. 18.04.2002. ADI n. 2.628/DF, Rel. Min. Sydney Sanches, Rel.p/ Acórdão Min. Ellen Gracie, j. 18.04.2002.
} 
em dois subitens. O primeiro deles tratará da argumentação vencedora, que teve base, principalmente, na impossibilidade de se analisar a constitucionalidade de Resolução do TSE. Já o segundo subitem trará a argumentação contida nos votos vencidos, qual seja, contrária à existência do princípio da coerência das coligações partidárias.

\subsubsection{Inexistência do controle de constitucionalidade concentrado da função normativa/regulamentar da Justiça Eleitoral}

O argumento vencedor no caso em comento trata da inexistência do controle de constitucionalidade da função normativa/regulamentar da Justiça Eleitoral. Para a Relatora designada, Ministra Ellen Gracie, o advento da verticalização não passou de mero ato interpretativo, não havendo, portanto, alteração normativa.

Votaram no mesmo sentido em curtos votos, ou seja, reconheceram que o advento da verticalização não passou de mero ato interpretativo emanado pelo TSE os Ministros Mauricio Corrêa, Néri da Silveira, Carlos Velloso 283 e Nelson Jobim ${ }^{284}$. O ato meramente interpretativo tem, portanto, natureza regulamentar, não sendo possível a norma impugnada ser alvo do controle de constitucionalidade concentrado.

\footnotetext{
283 Carlos Velloso destacou que a Resolução n. 20.993 "é um ato normativo secundário, porque decorrente de ato normativo primário. Já falamos que o ato normativo primário, do qual decorre o $\$ 1^{\circ}$ do art. $4^{\circ}$, da Instrução $n^{\circ}$ 55, do Tribunal Superior Eleitoral, é o art. $6^{\circ}$ da Lei $n^{\circ} 9.504 / 97^{\prime \prime}$.

284 Nelson Jobim, após defender, no STF, seu posicionamento exarado quando da decisão da Cta. n. 715 no TSE, também entendeu se tratar de ato meramente regulamentar, não havendo viabilidade de referida norma sofrer controle de constitucionalidade concentrado, conforme se depreende do trecho a seguir: "Tem a natureza de regulamento, mas vejam que é um ato claramente secundário, que decorre da interpretação que o TSE deu a esse dispositivo da Lei Eleitoral, artigo $6^{\circ}$ ".
} 
Merece maior destaque o voto exarado pelo Ministro Celso de Mello no tema. Mello ressalta que a Resolução ora impugnada tem caráter meramente secundário e, portanto, queda-se inviável seu controle de constitucionalidade, conforme trecho a seguir:

"É que o ato em causa revela-se efetivamente desprovido do necessário coeficiente de normatividade qualificada, configurando, por isso mesmo, ato de caráter meramente secundário, eis que se limitou a interpretar, na espécie, regra legal pertinente à celebração de coligações partidárias ${ }^{285 "}$.

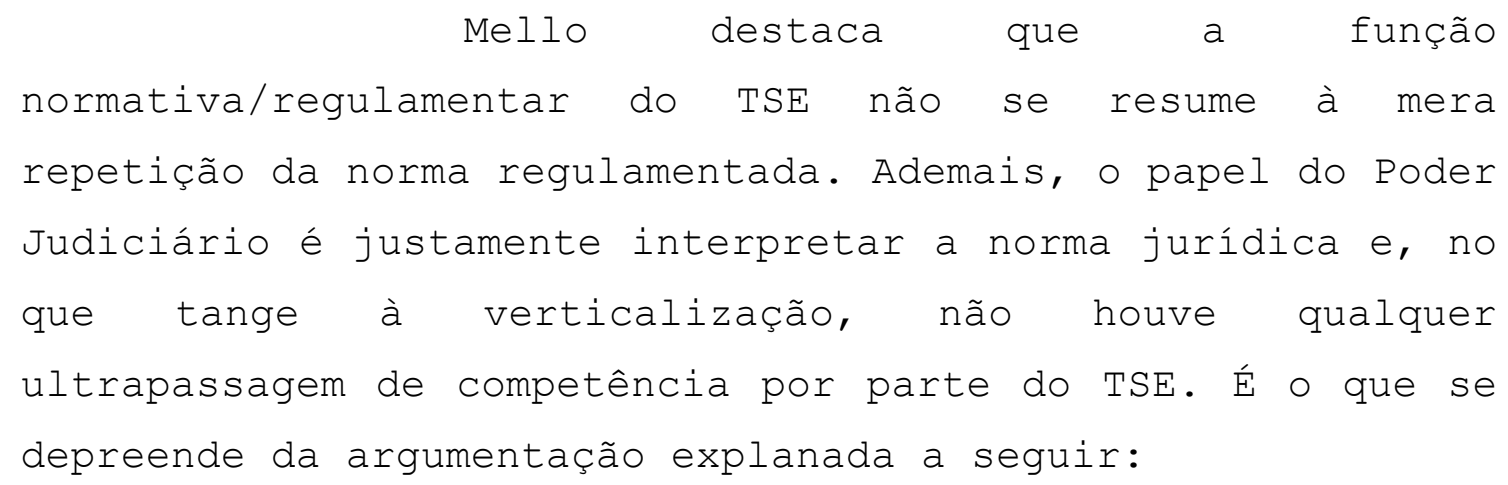

"Cumpre insistir que a função de interpretar as leis - cuja prática não faz instaurar situação de normatividade - revela-se prerrogativa essencial daqueles que as aplicam, incumbindo, ao Poder Judiciário, por efeito das próprias funções institucionais que lhe competem, o exercício dessa atribuição de ordem jurídica.

(...)

É preciso ter presente, neste ponto, que, não obstante os limites impostos à função regulamentar, o órgão estatal dela incumbido - o Tribunal Superior Eleitoral, no caso -, ao desempenhar, concretamente, a competência regulamentar de que se acha investido, não se reduz à condição de mero órgão de reprodução literal e de transcrição material do ato legislativo cujo conteúdo busca desenvolver, pormenorizar e explicitar, fundando em sua própria pré-compreensão do texto legal ${ }^{286, "}$.

Mello, finalmente, não descarta a possibilidade de a interpretação emanada pelo TSE ter

\footnotetext{
285 ADI n. 2.626/DF, Rel. Min. Sydney Sanches, Rel. p/ Acórdão Min. Ellen Gracie, j. 18.04.2002. ADI n. 2.628/DF, Rel. Min. Sydney Sanches, Rel. p/ Acórdão Min. Ellen Gracie, j. 18.04.2002. Voto do Min. Celso de Mello.

${ }^{286}$ ADI n. 2.626/DF, Rel. Min. Sydney Sanches, Rel. p/ Acórdão Min. Ellen Gracie, j. 18.04.2002. ADI n. 2.628/DF, Rel. Min. Sydney Sanches, Rel. p/ Acórdão Min. Ellen Gracie, j. 18.04.2002. Voto do Min. Celso de Mello.
} 
desrespeitado $\circ$ comando do art. $6^{\circ}$ da Lei das Eleições e até a possibilidade de haver inconstitucionalidade no $\$ 1^{\circ}$ do art. $4^{\circ}$ da Resolução n. 20.993 ora impugnado. Para o Ministro, se isso ocorrer, é hipótese de inconstitucionalidade reflexa ou oblíqua. Para haver a possibilidade de controle concentrado, é necessário que a possível inconstitucionalidade enseje confronto direto com a Constituição. Dessa forma, no caso em comento, o possível conflito se trava entre a Resolução impugnada e a Lei das Eleições, e não entre o ato normativo do TSE e a Constituição. Nessa toada, litteris:

"Essa antinomia, acaso configurada - e considerando-se a relação de imediatidade que o ato regulamentar deve manter com a lei que lhe constitui o pressuposto de validade e de eficácia traduzirá, quando muito, situação tipificadora de comportamento ilegal do Poder Público, insuscetível de exame em sede de jurisdição constitucional concentrada, consoante ressalta o magistério jurisprudencial desta Suprema Corte ${ }^{287,}$.

o julgamento do STF ora em comento merece críticas. Primeiramente, na prática, o supremo afastou o julgamento do mérito de um caso de enorme importância para a sociedade brasileira. A mudança repentina trazida pelo TSE às vésperas das eleições de 2002 alterou profundamente o cenário político do pleito daquele ano. No mais, o julgamento do mérito da controvérsia seria uma excelente oportunidade para a fixação dos limites da competência normativa/regulamentar do TSE.

Estes limites só foram fixados mais de dez anos depois, em sede do julgamento do Recurso

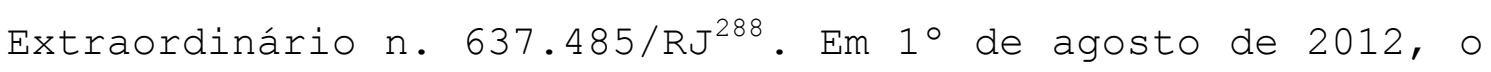
STF pacificou seu posicionamento acerca da possibilidade o

${ }^{287}$ ADI n. 2.626/DF, Rel. Min. Sydney Sanches, Rel. p/ Acórdão Min. Ellen Gracie, j. 18.04.2002. ADI n. 2.628/DF, Rel. Min. Sydney Sanches, Rel. p/ Acórdão Min. Ellen Gracie, j. 18.04.2002. Voto do Min. Celso de Mello.

${ }^{288} \mathrm{RE}$ n. 637.485/RJ, Rel. Min. Gilmar Mendes, j. 010.08.2012. 


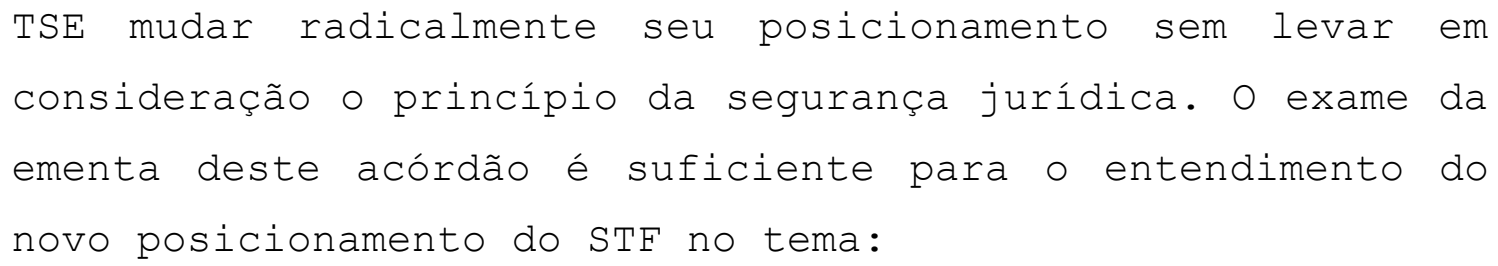

"Mudanças radicais na interpretação da Constituição devem ser acompanhadas da devida e cuidadosa reflexão sobre suas consequências, tendo em vista o postulado da segurança jurídica. Não só a Corte Constitucional, mas também o Tribunal que exerce o papel de órgão de cúpula da Justiça Eleitoral devem adotar tais cautelas por ocasião das chamadas viragens jurisprudenciais na interpretação de preceitos constitucionais que dizem respeito aos direitos políticos e ao processo eleitoral. Não se pode deixar de considerar o peculiar caráter normativo dos atos judiciais emanados do Tribunal Superior Eleitoral, que regem todo o processo eleitoral. Mudanças na jurisprudência eleitoral, portanto, têm efeitos normativos diretos sobre os pleitos eleitorais, com sérias repercussões sobre os direitos fundamentais dos cidadãos (eleitores e candidatos) e partidos políticos. (...) A importância fundamental do princípio da segurança jurídica para o regular transcurso dos processos eleitorais está plasmada no princípio da anterioridade eleitoral positivado no art. 16 da Constituição.(...) Em razão do caráter especialmente peculiar dos atos judiciais emanados do Tribunal Superior Eleitoral, os quais regem normativamente todo o processo eleitoral, é razoável concluir que a Constituição também alberga uma norma, ainda que implícita, que traduz o postulado da segurança jurídica como princípio da anterioridade ou anualidade em relação à alteração de jurisprudência do TSE. Assim, as decisões do Tribunal Superior Eleitoral que, no curso do pleito eleitoral (ou logo após o seu encerramento), impliquem mudança de jurisprudência (e dessa forma repercutam sobre a segurança jurídica), não têm aplicabilidade imediata ao caso concreto e somente terão eficácia sobre outros casos no pleito eleitoral posterior ${ }^{289 "}$. (grifos nossos)

Entendemos, portanto, que não há
razoabilidade na argumentação trazida pela maioria dos
Ministros do STF ao não conhecerem as duas ações diretas.
Primeiramente, diante do tamanho da controvérsia que o
advento da verticalização trouxe para o cenário político
brasileiro.

Ademais, $\circ \$ 1^{\circ}$ do art. $4^{\circ}$ da Resolução
n. 20.993/2002 trouxe evidente conteúdo normativo ao

${ }^{289} \mathrm{RE}$ n. 637.485/RJ, Rel. Min. Gilmar Mendes, j. 010.08.2012. 
ordenamento jurídico pátrio. A interpretação que originou a verticalização foi inserida em instrumento normativo emanado pelo TSE para regulamentar as coligações partidárias nas eleições gerais de 2002 de forma diferente da ocorrida nas eleições gerais anteriores, em 1998.

$\mathrm{Na}$ ADI n. 2.279/SC, em sede de medida cautelar, o Ministro Celso de Mello reconheceu que Resoluções da Justiça Eleitoral com caráter normativo podem ser alvo do controle de constitucionalidade concentrado. $\mathrm{Na}$ oportunidade, Mello ressaltou que

"Tratando-se, portanto, de ato estatal com suficiente densidade normativa, e revelando-se cabível, em consequência, sob tal perspectiva, a presente ação direta de inconstitucionalidade, passo a apreciar o pedido de medida cautelar nela formulado ${ }^{290 "}$.

Não conseguimos vislumbrar o motivo pelo qual o STF, por maioria, não ter considerado que a inclusão da obrigatoriedade de os partidos políticos observarem o princípio da coerência das coligações partidárias na Resolução que traz as normas gerais a serem aplicadas nas eleições de 2002 não ser ato revestido de caráter normativo. Houve clara inovação no posicionamento do TSE, posicionamento este que gerou celeuma e consequências graves ao cenário político brasileiro. Com o julgamento do RE n. 637.485/RJ, mais de dez anos depois, porém, tal questão restou acertadamente superada.

\subsubsection{Argumentação contrária à Verticalização}

O Ministro Relator originário das ações diretas em questão, sydney Sanches, restou vencido na oportunidade. Por isso, sua argumentação trazida será relatada e analisada neste subitem.

${ }^{290} \mathrm{ADI}$ n. 2.279-MC/SC, Rel. Min. Celso de Mello, j. 20.09.2000. 
Sanches inicia seu voto ressaltando que decisão do TSE impugnada não foi a proferida na Consulta $n$. 715, que resultou na edição da Resolução n. 21.002. A impugnação, na verdade, reside na possível inconstitucionalidade do $\$ 1^{\circ}$ do art. $4^{\circ}$ da Resolução $n$. 20.993. A Resolução emitida em sede de Consulta, segundo Sanches, tem caráter meramente administrativo. Já a Resolução n. 20.993, ao contrário, tem caráter regulamentar, havendo, no seu entender, possibilidade de sofrer controle concentrado de constitucionalidade.

Após essa alegação, o Ministro Relator originário ressalta, inicialmente, que a decisão do TSE que impôs a verticalização não atendeu aos requisitos presentes no art. 105 da Lei das Eleições 291 . De fato, a verticalização foi incluída na Resolução n. 20.993 sem qualquer audiência pública realizada. Sanches ressalta que a inovação legislativa trazida com o advento da verticalização foi chancelado ao arrepio da lei pelo próprio TSE ao incluir o princípio da coerência das coligações partidárias em resolução geral sobre as eleições de 2002, in verbis:

"Ora, no caso presente, foi também depois de responder a consulta (resposta administrativa aqui não impugnada) que o Tribunal Superior Eleitoral baixou a Instrução, que contém o dispositivo atacado nestes autos. Dirigida ela (a Instrução) a toda a Justiça Eleitoral, ou seja, a todos os Juízes de $1^{\circ}$ grau e Tribunais Regionais e envolvendo, assim, em todo o processo eleitoral, os candidatos e os Partidos Políticos eventualmente interessados em coligações $^{292}$ ".

\footnotetext{
${ }^{291}$ No momento do julgamento, referido artigo tinha a seguinte redação: "Art. 105. Até o dia 5 de março do ano da eleição, o Tribunal Superior Eleitoral expedirá todas as instruções necessárias à execução desta Lei, ouvidos previamente, em audiência pública, os delegados dos partidos participantes do pleito".

292 ADI n. 2.626/DF, Rel. Min. Sydney Sanches, Rel. p/ Acórdão Min. Ellen Gracie, j. 18.04.2002. ADI n. 2.628/DF, Rel. Min. Sydney Sanches, Rel. p/ Acórdão Min. Ellen Gracie, j. 18.04.2002. Voto do Min. Sydney Sanches.
} 
0
antevendo possível argumentação contrária, que o não conhecimento das ADIs faria com que a questão em debate somente chegasse ao STF por meio do sistema de controle de constitucionalidade difuso. Dessa forma, segundo Sanches, haveria prejuízo à estabilidade e à legitimidade das eleições, sendo, portanto, possível o STF evitar essa dificuldade. Nesse sentido, vale trazer o pensamento de Sydney Sanches, ipsis litteris:

"a questão [se não conhecidas as ADIs] só lhe chegará ao exame, no controle difuso de constitucionalidade, após as três instâncias precedentes, às vésperas do pleito eleitoral, na melhor das hipóteses, e até depois de apurado, com as notórias inconveniências e prováveis transtornos, que disso poderão resultar e podem ser evitados agora ${ }^{293}$,

Sydney Sanches demonstra que a

verticalização fere diretamente a segurança jurídica eleitoral, insculpida no art. 16 da Constituição ${ }^{294}$. Ademais, aponta que o advento da verticalização fere o entendimento previsto no art. 86 do Código Eleitoral quanto às circunscrições eleitorais no País ${ }^{295}$.

\footnotetext{
Neste tópico, o Relator originário destaca que não há sentido na vinculação entre a circunscrição nacional e estadual. No seu entendimento, a vinculação prevista no art. $6^{\circ}$ da Lei das Eleições é a mesma já reconhecida pelo TSE no julgamento da Consulta n. 382 (Resolução n. 20.126/98).
}

\footnotetext{
293 ADI n. 2.626/DF, Rel. Min. Sydney Sanches, Rel. p/ Acórdão Min. Ellen Gracie, j. 18.04.2002. ADI n. 2.628/DF, Rel. Min. Sydney Sanches, Rel. p/ Acórdão Min. Ellen Gracie, j. 18.04.2002. Voto do Min. Sydney Sanches.

${ }^{294}$ O princípio da anterioridade eleitoral será debatido com a atenção necessária no item 4.9.1 infra.

295 "Art. 86. Nas eleições presidenciais, a circunscrição serão País; nas eleições federais e estaduais, o Estado; e nas municipais, o respectivo município".
} 
- Relator originário destaca, já antevendo possível argumentação contrária, que o não conhecimento das ADIs faria com que a questão em debate somente chegasse ao STF por meio do sistema de controle de constitucionalidade difuso.

Sanches, por fim, ressalta mais dois fatores. O primeiro deles cinge-se no fato de que o próprio TSE, na Resolução n. 12.867, de 24 de julho de 1986, entendeu que os pressupostos de validade da instrução guardam vinculação necessária com seus limites - na verticalização, a seu ver, os limites foram ultrapassados. Ademais, a Constituição foi desrespeitada também em seu princípio da reserva legal, pois a competência constitucional para legislar sobre direito eleitoral é do Congresso Nacional (art. 48 c/C art. 22, I, ambos da CFRB).

O Ministro Sepúlveda Pertence também contra a verticalização, consoante seu entendimento já exarado no TSE. Ao conhecer das ações diretas, determinou que a competência do TSE na questão era normativa, pois a decisão que resultou na verticalização tratava-se de "norma de decisão, e não apenas de decisão sobre normas ${ }^{296 "}$.

Pertence estabelece o verdadeiro paradoxo da questão quando analisada sob o foco do art. 16 da Constituição. Por entender que O TSE, ao tratar da verticalização, estava exercendo sua função normativa e inovando "o bloco da legislação eleitoral", Pertence atesta qual é o verdadeiro ponto controvertido: a verticalização foi resultado de mera interpretação ou nova regulamentação

\footnotetext{
296 ADI n. 2.626/DF, Rel. Min. Sydney Sanches, Rel. p/ Acórdão Min. Ellen Gracie, j. 18.04.2002. ADI n. 2.628/DF, Rel. Min. Sydney Sanches, Rel. p/ Acórdão Min. Ellen Gracie, j. 18.04.2002. Voto do Min. Sepúlveda Pertence.
} 


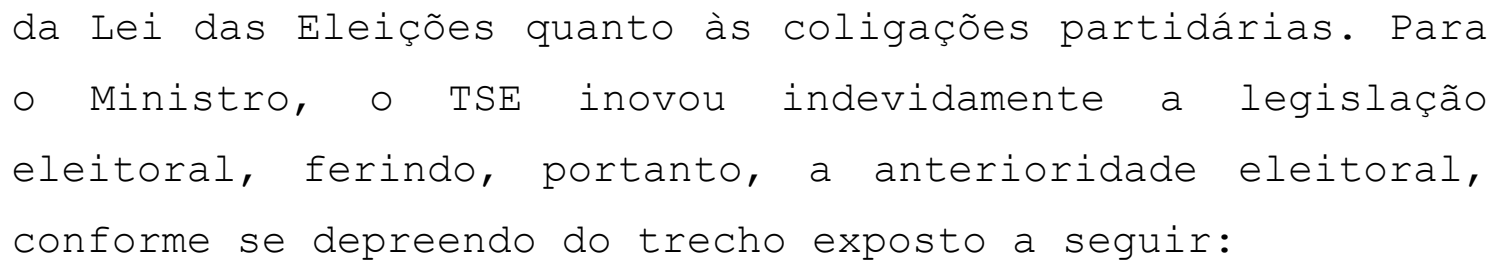

Então, cuida-se de saber se o art. 16, da Constituição - e, não é preciso lembrar, ele se refere à lei - aplica-se ou não, com mais razão -, a atos de menor hierarquia, desde que estes inovem no chamado - por mim, na introdução do meu voto - 'bloco da legislação eleitoral', em seus diversos níveis: o constitucional, o legal e até o regulamentar das instruções do TSE. Estas têm uma força normativa muito diversa da jurisprudência dos demais tribunais do País, precisamente por dispor o TSE desse poder muito mais como órgão de administração do processo eleitoral do que como órgão jurisdicional -, de dar feição normativa à sua inteligência da lei.

O ponto, então, a saber, é se houve alteração da regulamentação ou da interpretação - se quiserem - da mesma lei, de um processo eleitoral para outro. Estou, Sr. Presidente, que a resposta é afirmativa. A Lei $\mathbf{n}^{\mathbf{0}} \mathbf{9 . 5 0 4}$, de 1997 - há décadas se houve precedentes - é, até aqui, o ensaio mais bem sucedido do sonho de uma lei eleitoral relativamente permanente. $E$, sem alterações de profundidade, já regeu três pleitos eleitorais: as eleições gerais de 1998, a eleição municipal de 2000 e vai reger agora as eleições gerais de $\mathbf{2 0 0 2}{ }^{297 "}$. (grifos nossos)

O trecho acima grifado deixa nítida a
impressão emanada por Pertence. Para ele, o fato de a Lei
das Eleições já ter regido duas eleições diferentes sem
profundas alterações significa que a nova interpretação
sobre as coligações eleitorais do TSE alterou a
normatização sobre o tema.

Ao explicar seu posicionamento, Pertence faz referência à lógica da verticalização quanto à referência normativa sobre as circunscrições. Segue seu raciocínio ao ressaltar que a nova interpretação é incompatível com a exarada pelo TSE no mesmo tema em 1998

\footnotetext{
297 ADI n. 2.626/DF, Rel. Min. Sydney Sanches, Rel. p/ Acórdão Min. Ellen Gracie, j. 18.04.2002. ADI n. 2.628/DF, Rel. Min. Sydney Sanches, Rel. p/ Acórdão Min. Ellen Gracie, j. 18.04.2002. Voto do Min. Sepúlveda Pertence.
} 
(vide item 4.3 supra) ${ }^{298}$. Houve, na sua visão, alteração da norma eleitoral, fato que constitui flagrante desrespeito à anterioridade eleitoral, conforme trecho de seu voto ora explanado:

"Basta-me que a interpretação subjacente à Resolução, acima mencionada [Resolução n. 20.126/98 - Consulta n. 382], tomada para o pleito de 1988, seja diversa da que predominou, agora, para a eleição de 2002. Ela mostra, a meu ver, a existência de inovação no bloco da regulamentação de lei eleitoral. Ao inovar, violou-se o art. 16 da Constituição Federal, questão de mérito, mas puramente constitucional, cuja discussão, no entanto, dependeria do conhecimento da ação direta ${ }^{299, "}$

Por fim, Pertence defende o conhecimento da ação e seu consequente provimento diante do fato de que a questão em jogo tinha diversas nuances constitucionais, principalmente no que tange à violação ao princípio da anterioridade eleitoral. Para Pertence, a inconstitucionalidade formal do advento da verticalização graças à exacerbação, por parte do TSE, de sua competência normativa - foi tamanha ao ponto de ser impossível ter uma leitura apenas de caráter infraconstitucional da norma impugnada. Nesse sentido, litteris:

"Em síntese, a invocação do art. 16 é adequada e põe questão constitucional, quando se assenta que houve alteração na interpretação normativa da mesma norma, pelo TSE, em dois processos eleitorais subsequentes. E torna, então, grave a questão constitucional de indagar-se se essa inovação, que não pode ser assentada por lei, poderá ser feita em instrumento, como tantas

\footnotetext{
298 Mais uma vez, torna-se relevante separar o pensamento do Ministro Sepúlveda Pertence no tema: "Venceu a tese de que, simultâneas as eleições presidenciais e as que se travam na circunscrição estadual, dada a simultaneidade, a circunscrição nacional compreende a circunscrição estadual. Donde, havendo coligação 'a', 'b', 'c', 'd' para Presidente da República, há de haver simetria nas coligações que se formarem para as eleições majoritárias estaduais para o Governador de Estado e Senador. Essa formulação, elegantemente posta sobre o pálio na teoria dos conjuntos, seria a interpretação precedente, a leitura precedente do TSE da mesma lei? A meu ver, não. E me parece ela, claramente, incompatível senão com os termos, com a literalidade, com a lógica que presidiu a Resolução $n^{\circ} 20.126$, relatada, antes das eleições de 1998, pelo eminente Ministro Néri da Silveira".

299 ADI n. 2.626/DF, Rel. Min. Sydney Sanches, Rel. p/ Acórdão Min. Ellen Gracie, j. 18.04.2002. ADI n. 2.628/DF, Rel. Min. Sydney Sanches, Rel. p/ Acórdão Min. Ellen Gracie, j. 18.04.2002. Voto do Min. Sepúlveda Pertence.
} 
vezes se disse aqui, que é secundário mais do que o de outro. A interpretação da lei, no caso, está prenhe da solução de questões constitucionais, levando à divisão do TSE, de tal modo imbricadas no tema da validade da norma regulamentar questionada, que não é possível reduzir esse dispositivo impugnado ao resultado de uma leitura infraconstitucional da lei ordinária ${ }^{300,}$.

\begin{abstract}
O terceiro voto vencido foi proferido
pelo Ministro Marco Aurélio. Inicialmente, ele ressalta o fato de que em 1998, O TSE sequer cogitou sobre a possibilidade de verticalização das coligações partidárias ao julgar a Consulta n. 382. Assim, haveria possível contradição entre o decidido em 1998 e o advento da verticalização, em 2002 .
\end{abstract}

Segue seu parecer trazendo à baila o princípio da anterioridade eleitoral. Nesse sentido, aponta Marco Aurélio que se a Constituição prevê que a lei que altera dispositivo sobre processo eleitoral em período inferior a um ano da realização da eleição não gera eficácia neste pleito, um ato normativo infralegal (na hipótese, uma Resolução do TSE) não pode jamais ter o condão de ferir dispositivo constitucional, conforme manifestação exposta a seguir:

"Ora, se a Carta da República, mediante o preceito do artigo 16, impõe, quanto à lei em sentido formal e material, a anterioridade de um ano, o que se dirá relativamente a algo que tenha força de lei, como a medida provisória, e, quanto a um ato do próprio Tribunal Superior Eleitoral - cuja competência normativa está aquém até da outorgadas pelo artigo 114 da Constituição Federal à Justiça do Trabalho - que venha dispor, inovando - e não há a menor dúvida de que houve uma inovação, considerada a própria prática do Tribunal Superior Eleitoral nas eleições de 1998 - as balizas do pleito a sete meses deste ${ }^{301,}$.

\footnotetext{
${ }^{300}$ ADI n. 2.626/DF, Rel. Min. Sydney Sanches, Rel. p/ Acórdão Min. Ellen Gracie, j. 18.04.2002. ADI n. 2.628/DF, Rel. Min. Sydney Sanches, Rel.p/ Acórdão Min. Ellen Gracie, j. 18.04.2002. Voto do Min. Sepúlveda Pertence.

301 ADI n. 2.626/DF, Rel. Min. Sydney Sanches, Rel. p/ Acórdão Min. Ellen Gracie, j. 18.04.2002. ADI n. 2.628/DF, Rel. Min. Sydney Sanches, Rel. p/ Acórdão Min. Ellen Gracie, j. 18.04.2002. Voto do Min. Marco Aurélio.
} 
Enfatize-se que o Ministro insiste no argumento, a nosso ver acertado, de que O TSE inovou a legislação eleitoral ao prever a vigência da verticalização das coligações partidárias. Diante de fato de que quando provocado, em 1998, O TSE não fez qualquer referência à existência da verticalização no momento em que, pela primeira vez, em sede de Consulta, emanou sua interpretação sobre 0 art. $6^{\circ}$ da Lei das Eleições, não poderia o Tribunal Superior Eleitoral, menos de um ano antes da data de realização das eleições, inserir nas suas resoluções gerais nova norma sobre as coligações partidárias.

Marco Aurélio encerra sua manifestação sustentando, indiretamente, que o Judiciário também deve respeitar 0 art. 16 da Constituição, conferindo estabilidade à legislação eleitoral e evitando mudanças abruptas, quer na sua competência tradicional (a jurisdicional), quer na sua função sui generis, conforme aparte ora separado:

"Estamos diante de um desafio constitucional para se ter como a prevalecer a lei que a todos submete, a Constituição da República, evitando-se que o Judiciário, quer no campo administrativo, quer no jurisdicional, acabe sendo uma caixa de surpresas $^{302,}$.

O último voto favorável à viabilidade das ações diretas apresentadas foi exarado pelo Ministro Ilmar Galvão. Seu primeiro argumento consistiu na análise do dispositivo constitucional que obriga o partido político a ter caráter nacional. O $\$ 1^{\circ}$ do art. $7^{\circ}$ da Lei dos Partidos Políticos (Lei n. 9.096/1995) ${ }^{303}$ prevê que no momento de seu

\footnotetext{
302 ADI n. 2.626/DF, Rel. Min. Sydney Sanches, Rel. p/ Acórdão Min. Ellen Gracie, j. 18.04.2002. ADI n. 2.628/DF, Rel. Min. Sydney Sanches, Rel. p/ Acórdão Min. Ellen Gracie, j. 18.04.2002. Voto do Min. Marco Aurélio.

303 "Art. $7^{\circ}$ o partido político, após adquirir personalidade jurídica na forma da lei civil, registra seu estatuto no Tribunal Superior Eleitoral.
} 
registro no TSE, haverá a legenda de demonstrar o apoio de parte do eleitorado brasileiro em boa parte do território nacional.

O texto do $\$ 1^{\circ}$ é de clareza ímpar: o requisito de caráter nacional dos partidos é considerado cumprido quando, no registro no TSE, a sigla comprove ter apoio entre o eleitorado nacional, sendo esse suporte obrigatório em, ao menos, um terço dos Estados. Nesse tópico, Galvão menciona que essa exigência legal é a única concernente ao caráter nacional dos partidos, "não se podendo dela extrair qualquer comando relativo a coligações ${ }^{304 \prime \prime}$.

Ao tanger a anterioridade eleitoral, Ilmar Galvão aventou que a Resoluçãon. 20.993, ao prever a verticalização, "desenganadamente exorbitou de seus limites, inovando na ordem jurídica eleitoral". Além do art. 16 da Constituição, a decisão do TSE que resultou na existência do princípio da coerência das coligações partidárias também ofendeu a legalidade, uma vez que os partidos não estão obrigados por lei a se coligarem conforme a interpretação do TSE no ponto ${ }^{305}$.

$\$ 1^{\circ}$ Só é admitido o registro do estatuto de partido político que tenha caráter nacional, considerando-se como tal aquele que comprove o apoiamento de eleitores correspondente a, pelo menos, meio por cento dos votos dados na última eleição geral para a Câmara dos Deputados, não computados os votos em branco e os nulos, distribuídos por um terço, ou mais, dos Estados, com um mínimo de um décimo por cento do eleitorado que haja votado em cada um deles".

304 ADI n. 2.626/DF, Rel. Min. Sydney Sanches, Rel. p/ Acórdão Min. Ellen Gracie, j. 18.04.2002. ADI n. 2.628/DF, Rel. Min. Sydney Sanches, Rel. p/ Acórdão Min. Ellen Gracie, j. 18.04.2002. Voto do Min. Ilmar Galvão.

305 Nesse sentido, Ilmar Galvão atestou que "Se o Poder Legislativo não pode mudar a lei um ano antes da eleição, muito menos o Poder Judiciário poderá baixar normas, inovando, dentro do período de um ano. Não pode". 
Por último, Galvão demonstra que nas eleições de 1988 houve a eleição de um deputado federal filiado ao PSDB que, no seu estado, celebrou coligação com - PT (em 1998, O PSDB foi adversário do PT nas eleições presidenciais), fato que corroboraria com a tese de que a verticalização se tratou de uma inovação legislativa. Vigendo a coerência nas coligações partidárias, Ilmar Galvão entendeu que seria necessária, no registro da candidatura, a apresentação de uma certidão por parte do candidato demonstrando que seu partido respeita a verticalização. E destaca: "se a lei não fez isso [exigência de certidão comprovando o respeito à verticalização], não é possível que a Justiça Eleitoral o faça ${ }^{306 \prime \prime}$.

A análise feita nesse item demonstra que - STF, ao não conhecer das duas ações diretas ajuizadas, chancelou implicitamente a decisão exarada pelo TSE.

\subsection{Reação Legislativa: a Proposta de Emenda Constitucional n. 548/2002}

Após a decisão do TSE que instituiu a verticalização das coligações partidárias e o aval indireto do STF para a nova interpretação, o Congresso Nacional reagiu. Houve a apresentação de vários projetos de lei e de emenda constitucional com o mesmo objetivo: extirpar a nova interpretação do TSE sobre as coligações partidárias do ordenamento jurídico brasileiro.

\footnotetext{
306 ADI n. 2.626/DF, Rel. Min. Sydney Sanches, Rel. p/ Acórdão Min. Ellen Gracie, j. 18.04.2002. ADI n. 2.628/DF, Rel. Min. Sydney Sanches, Rel. p/ Acórdão Min. Ellen Gracie, j. 18.04.2002. Voto do Min. Ilmar Galvão.
} 
O primeiro Projeto de Lei apresentado, em 12 de março de 2002, foi o de n. 6.256/2002, de autoria do deputado federal Valdemar Costa Neto (PL/São Paulo). Seu objetivo era conferir "interpretação autêntica" ao art. $6^{\circ}$ da Lei das Eleições.

O PL n. 6.256 previa o acréscimo de dois parágrafos ao art. $6^{\circ}$ da Lei das eleições, com a seguinte redação:

“Art. $1^{\circ}$ Acrescente-se ao Art. $6^{\circ}$ da Lei no 9.504 de 1997 os seguintes parágrafos 1 e 2 :

'Art. $6^{\circ}$

$\S 1^{\circ}$ Considera-se que nas eleições presidenciais, a circunscrição seja o país; nas eleições federais, isto é, para governador, senador, deputados federais e deputados estaduais, os estados e o distrito federal; e nas municipais, isto é, para prefeitos e vereadores, o respectivo município.

$\S 2^{\circ}$ Considera-se que a coligação realizada em uma circunscrição seja, para todos os efeitos, independentemente das coligações realizadas em outras circunscrições, podendo livremente integrar a coligação em dada circunscrição partido distinto daqueles que integraram coligação em outra circunscrição'.

Art. $2^{\circ}$ Esta lei entra em vigor na data de sua publicação".

O deputado federal Costa Neto justifica seu projeto com base no fato de haver interpretações que "diferem substancialmente do espírito do legislador ao redigir a lei ${ }^{307 " .}$

A inclusão da interpretação autêntica na Lei das Eleições afastaria, no entendimento do deputado federal, dois obstáculos. O primeiro deles é, por óbvio, a interpretação exarada pelo TSE. O segundo é o mandamento constitucional do respeito ao princípio da anterioridade eleitoral (art. 16 da CRFB).

Para Valdemar Costa Neto,

307 Projeto de Lei n. 6.256, de 2002. In: Diário da Câmara dos Deputados, ano LVII, n. 032, Sexta-feira, 5 de abril de 2002, p. 13.562 . 
"uma lei que fixe a interpretação autêntica é, em tudo, contemporânea à lei original e, como se constata de sua própria natureza apenas interpretativa, não modifica o conteúdo da lei original; não fere, portanto, sob nenhum aspecto, o Art. 16 da Constituição Federal ${ }^{308, "}$.

O deputado ressalta na Justificação do Projeto de Lei que a vontade do legislador era de que cada eleição correspondesse a uma circunscrição. Assim, a Lei das Eleições só preveria o respeito à coligação majoritária quando da eleição proporcional dentro daquela circunscrição. Como não há na circunscrição nacional eleição proporcional, "entende-se não aplicável a simetria exigida pelo art. da Lei n 9.504/97". Por fim, o deputado ressalta que cabe ao Legislativo "por fim à celeuma criada a partir da recente decisão do TSE", uma vez que este julgamento "em última análise, alterou o processo eleitoral já em andamento, configurando incontestável afronta ao art. 16 da Constituição Federal ${ }^{309 \prime \prime}$.

Em 24 de abril de 2002, o Colégio de Líderes da Câmara apresenta requerimento de urgência ao projeto em voga ao Plenário. O Relator do projeto, deputado federal Bispo Rodrigues (PL/Rio de Janeiro), apresenta seu parecer somente em 21 de novembro de 2002, ou seja, após o fim das eleições daquele ano. Após intensa movimentação na Comissão de Constituição e Justiça e de Cidadania, somente em 14 de setembro o parecer é aprovado. Mesmo em regime de prioridade, o projeto continua aguardando andamento no Plenário desde 10 de dezembro de 2007 .

\footnotetext{
308 Projeto de Lei n. 6.256, de 2002. In: Diário da Câmara dos Deputados, ano LVII, n. 032, Sexta-feira, 5 de abril de 2002, p. 13.562 .

309 Projeto de Lei n. 6.256, de 2002. In: Diário da Câmara dos Deputados, ano LVII, n. 032, Sexta-feira, 5 de abril de 2002, p. $13.562-13.563$.
} 
Já o Senado teve como reação a formulação de proposta de reforma do texto constitucional. De autoria do senador Bernardo Cabral (PFL/Amazonas), a PEC n. 4/2002 tinha visava a garantir maior espaço à autonomia partidária na celebração de coligações, alterando a redação do $\$ 1^{\circ}$ do art. 17 da Constituição. A principal justificativa do projeto era a de reestabelecer a interpretação histórica da disposição constitucional que obriga os partidos políticos a terem caráter nacional. Segundo o senador Cabral, o caráter nacional opõe-se à estruturação meramente regional, como ocorria no Brasil até o advento da Revolução de 1930.

No dia 27 de fevereiro, o senador amazonense já havia colhido o número de assinaturas necessárias para protocolizar a proposta. No Senado, o projeto teve tramitação razoavelmente rápida. Sob a relatoria do senador José Fogaça (PMDB/Rio Grande do Sul), a Comissão de Constituição e Justiça a aprovou rapidamente em 3 de abril de $2002^{310}$.

No Plenário, a votação em primeiro turno ocorreu em 8 de maio de 2002, com 60 votos favoráveis, 4 contrários e 2 abstenções. Em 4 de junho de 2002, a PEC n. 4/2002 foi aprovada em segundo turno, com 57 votos a favor, cinco contra e uma abstenção. A PEC foi remetida à Câmara dos Deputados em 12 de junho de 2002 .

Recebida pela Comissão de Constituição e Justiça e de Cidadania em 2 de julho de 2002, somente em 13 de fevereiro de 2004 ganhou um relator (deputado federal José Ivo Sartori - PMDB/Rio Grande do Sul). Seu parecer foi favorável à PEC, que, na Câmara, ganhou o número 548/2002.

310 O senador gaúcho destacou em seu parecer que a verticalização geraria um fortalecimento exagerado das cúpulas partidárias, havendo possibilidade de intervenções indevidas nos diretórios estaduais. 
Em 18 de março de 2005, a PEC ganham novo relator (deputado Inaldo Leitão (PL/Paraíba). Seu parecer é igualmente positivo.

Em 11 de maio de 2005, o então presidente da Câmara, Severino Cavalcanti (PP/Pernambuco) resolve criar Comissão Especial para proferir parecer sobre o tema. A comissão teria trinta e um membros. A relatoria ficou sob a guarda do deputado federal Pauderney Avelino (PFL/Amazonas) .

Avelino, em seu parecer, deixou nítida a intenção do Congresso ao formular a PEC: dar dimensão constitucional à resposta do Legislativo. Como O TSE utilizou critérios constitucionais na construção da interpretação que resultou na verticalização, cabia ao Congresso contra-atacar da mesma forma. Segundo Avelino,

"promover alteração diretamente na Carta Magna é a única forma de garantir a liberdade de os partidos definirem suas coligações, impedindo que interpretações supervenientes alterem o escopo buscado pelo legislador ${ }^{311 "}$.

Indiretamente, a Comissão Especial alega que com a aprovação da PEC, haveria homenagem ao princípio da segurança jurídica, conforme se depreende do trecho a seguir:

"É fundamental dirimir as controvérsias oriundas das polêmicas posições jurisprudenciais das mais altas Cores pátrias, estabelecendo uma norma que dê segurança aos agentes políticos sobre quais são as regras em vigor, impedindo mudanças de última hora, que tumultuem o processo eleitoral. E a melhor forma para isso, neste momento, é aprovar a Proposta de Emenda à Constituição oriunda do Senado Federal ${ }^{312 \text { ". }}$

\footnotetext{
311 Parecer da Comissão Especial destinada a proferir parecer sobre a Proposta de Emenda à Constituição $\mathrm{n}^{\circ}$ 548-A, de 2002 .

312 Parecer da Comissão Especial destinada a proferir parecer sobre a Proposta de Emenda à Constituição n 548-A, de 2002 .
} 
Por fim, o parecer ressalta que a PEC em questão traria de volta a vigência interpretativa histórica da regra constitucional que obriga os partidos políticos a terem caráter nacional, ou seja, que as agremiações partidárias devem ter expressão nacional, "para que sejam evitadas agremiações de natureza estritamente regional, típicas da chamada República Velha". Destaca o parecer que partidos são "estruturas perenes", enquanto as coligações são "alianças temporárias (...), sem qualquer estrutura permanente $e^{313 \prime \prime}$.

A discussão em Plenário foi iniciada somente em 16 de novembro de 2005. A PEC n. 548/2002 foi aprovada em primeiro turno na Câmara dos Deputados somente em 25 de janeiro de $2006^{314}$. 343 deputados votaram a favor da PEC. 143 votaram negativamente e houve uma abstenção. Em 8 de fevereiro de 2006, em segundo turno, a Câmara aprovou a PEC: 329 deputados votaram a favor e 143 foram contrários. A sessão conjunta para promulgação ocorreu em 8 de março de 2006, ou seja, poucos dias após a confirmação do TSE de que a verticalização vigeria nas eleições de outubro de 2006 .

Foi promulgada, afinal a Emenda Constitucional n. 52, emenda que será objeto de análise no item 4.6. A lentidão da Câmara na discussão e aprovação da PEC, com sua promulgação poucos dias depois da ratificação da vigência da verticalização pelo TSE (vide item 4.10) trará ao Supremo Tribunal Federal novamente a discussão sobre a verticalização.

\footnotetext{
313 Parecer da Comissão Especial destinada a proferir parecer sobre a Proposta de Emenda à Constituição n 548-A, de 2002.

314 Somente os deputados do PT e do PP tiveram como orientação da liderança o voto negativo à PEC. PSDB e PSOL liberaram seus filiados. Já PMDB, PFL, PTB, PL, PSB, PDT, PPS, PC do B, PV, PSC, PRONA, PMR e PTC orientaram suas respectivas bancadas pelo voto favorável.
} 


\subsection{Consultas formuladas ao Tribunal Superior Eleitoral entre 2003 e 2005}

O Tribunal Superior Eleitoral foi
provocado por duas vezes a se manifestar sobre a
verticalização das coligações partidárias entre 2003 e
2005 .

A primeira delas, protocolizada pelo deputado federal Jorge Alberto (PMDB/Sergipe), tinha como objetivo saber se a verticalização teria eficácia ou não nas eleições municipais de $2004^{315}$. Eis o teor da consulta, in verbis:

“(...) consulto Vossa Excelência sobre se há possibilidade de aplicação do princípio da verticalização nos pleitos municipais do próximo ano. Caso contrário, se será permitido coligações partidárias diferenciadas nos municípios do mesmo Estado Federativo".

O Ministro Relator, Fernando Neves, inicia seu voto manifestando sua preferência pela utilização dos termos "princípio da coerência na formação de coligações" a utilizar da cunhagem popular "verticalização" quando tratar do tema, já que o TSE "não obrigou repetição da mesma coligação nas diversas esferas dos cargos em disputa", mas sim "esclareceu sobre a impossibilidade de partidos adversários na circunscrição nacional, mais ampla, serem aliados nas circunscrições estaduais, incluídas naquela circunscrição ${ }^{316 " . ~}$

Assim, para o Relator, nas eleições municipais de 2004 não haveria a vigência da verticalização, uma vez que o eleitor só vota em cargos na

\footnotetext{
${ }^{315}$ Cta. n. 901/DF, Rel. Min. Fernando Neves, Resolução n. 21.474, de 26 de agosto de 2003.

${ }^{316}$ Cta. n. 901/DF, Rel. Min. Fernando Neves, Resolução n. 21.474, de 26 de agosto de 2003.
} 
mesma circunscrição, o Município. A Consulta, portanto, foi respondida negativamente para o primeiro questionamento.

Já o segundo ponto foi respondido positivamente pelo TSE. Diante de 0 art. $6^{\circ}$ da Lei das Eleições determinar que os partidos políticos podem, dentro de uma mesma circunscrição, celebrar coligações para as duas eleições (majoritária e proporcional), havendo vedação, conforme interpretação exarada na consulta $n$. 382/DF (Resolução n. 20.126/1998 - vide item 4.2 .2 supra), a inserção de partido que não faz parte da coligação majoritária em eventual coligação proporcional, não há qualquer proibição à celebração de coligações diferenciadas em municípios que fazem parte de um mesmo Estado-membro.

Nesta Consulta, a decisão foi unânime. Votaram com o Relator os seguintes Ministros: Sepúlveda Pertence, Ellen Gracie, Carlos Velloso, Barros Monteiro, Francisco Peçanha Martins e Luiz Carlos Madeira.

Nossa crítica, nesse ínterim, permanece. Nossa opinião, como já demonstrado no item 4.3, é de que não há argumento, legal, constitucional ou teórico, de que algum dia deveria ter vigido a verticalização das coligações partidárias. Ainda que se leve em conta que o princípio da coerência nas coligações vigeu nas eleições gerais de 2002 e 2006, O TSE decidiu incoerentemente no nosso modesto ver, que para as eleições municipais de 2004 não seria aplicado esse princípio.

Não se utiliza nas eleições municipais, obviamente, a teoria dos conjuntos circunscricionais. No entanto, diante da interpretação exarada pelo TSE quando do advento da verticalização das coligações partidárias no que 
tange à exigência constitucional de caráter nacional dos partidos, deveria ser lógico o fato de que nas 5.564 (cinco mil, quinhentas e sessenta e quatrol eleições municipais realizadas a cada quatro anos no Brasil devesse prevalecer também o princípio da coerência partidária.

Para O TSE, este princípio só deveria viger, paradoxalmente, nas eleições gerais (estaduais, distrital e nacional). Dois anos depois, no pleito municipal, o partido não precisaria demonstrar coerência, sendo liberado a aliar-se em qualquer município com seus adversários políticos no âmbito federal ou mesmo no âmbito estadual.

Nesta consulta, mesmo que indiretamente, na verdade, tacitamente, levou-se em conta a realidade brasileira no sentido de que partidos rivais no âmbito federal podem ser aliados em alguns Estados-membros ou até em vários Municípios e não em outros.

Também em 2003 foi apresentada nova Consulta ao TSE sobre a verticalização ${ }^{317}$. O deputado federal Murilo Zauith (PFL/Mato Grosso do Sul) faz singelo questionamento: "Como poderão ser feitas as clogações nas eleições proporcionais de 2004 para as Câmaras de Vereadores?". O Ministro Relator, Carlos Velloso, somente informa que a resposta a esta pergunta já havia sido exarada na Consulta n. 901/DF, consignando que "nas eleições municipais serão permitidas coligações diferenciadas em municípios diversos no mesmo estado ou

\footnotetext{
${ }^{317}$ Cta. n. 930/DF, Rel. Min. Carlos Velloso, Resoluçãon. 21.500, de 16
} de setembro de 2003. 
não, não incidindo o princípio da coerência na formação de coligação ${ }^{318 " \prime}$.

Após a eleição municipal de 2004, foi
apresentada Petição ao TSE tratando novamente da
verticalização 319 . O deputado federal João Caldas
(PL/Alagoas) requereu o seguinte:

"Com fundamento no Projeto de Lei no 6.256-A/2002, que dispõe sobre a interpretação autêntica do artigo $6^{\circ}$ da Lei $n^{\circ}$ 9.504/1997, e que foi aprovado no dia 10 de novembro de 2004 pela Comissão de Constituição e Justiça e de Cidadania (CCJC) da Câmara dos Deputados, requeiro a esta Corte Superior que seja declarado insubsistente o 'princípio da verticalização' (ou 'princípio da coerência na formação das coligações eleitorais') nas eleições majoritárias do ano de 2006”.

Em singelo voto, o Ministro Relator respondeu: "Senhor Presidente, a existência de simples projeto de lei não é motivo para que a corte altere a orientação estabelecida em Resolução. Indefiro".

\subsection{Resolução n. 22.161 do TSE (Consulta n. 1.185): a confirmação da Verticalização para as eleições de 2006}

A primeira Consulta tratando da verticalização analisada pelo TSE em 2006 foi apresentada por Ronaldo Nóbrega Medeiros, membro da Comissão Executiva Nacional do PSL - Partido Social Liberal. A questão apresentada tinha como claro objetivo, resumidamente, saber se $O$ TSE considerava ainda vigente a verticalização das coligações partidárias, como pode se depreender do questionamento apresentado, in verbis:

\footnotetext{
${ }^{318}$ Cta. n. 930/DF, Rel. Min. Carlos Velloso, Resoluçãon. 21.500, de 16 de setembro de 2003. Votação unânime. Votaram com o Relator os Ministros Sepúlveda Pertence, Ellen Gracie, Barros Monteiro, Francisco Peçanha Martins, Fernando Neves e Luiz Carlos Madeira.

319 Pet. n. 1.591/DF, Rel. Min. Luiz Carlos Madeira, Resolução n. 21.986, de 15 de fevereiro de 2005 .
} 
"Pode um determinado partido político, via Resolução do Órgão Nacional, publicada no Diário Oficial da União, até cento e oitenta dias antes das eleições, estabelecer normas que autorizem coligações híbridas que não respeitem o paradigma da coligação nacional, ou seja, possam livremente estabelecer coligações partidárias nas eleições estaduais, no entendimento do art. $7^{\circ}, \S 1^{\circ}$, da Lei $n^{\circ} 9.504$ de 30 de setembro de 1997, nas formações das coligações? ${ }^{320}$

O intuito do PSL era evidente. A hipótese trazida no questionamento era absolutamente contrária ao espírito da verticalização das coligações partidárias. Ao perguntar ao TSE se era possível um partido fixar diretrizes que autorizassem "coligações híbridas que não respeitem o paradigma da coligação nacional", fica muito claro que a intenção do PSL era de, no mínimo, saber se o TSE, em nova composição, entendia ainda vigente o princípio da coerência das coligações partidárias.

O Ministro Relator, Marco Aurélio, inicia seu voto com uma observação bastante peculiar. Sua interpretação do art. $6^{\circ}$ da Lei das Eleições levava em conta a autonomia dos partidos políticos prevista no art. 17 da Constituição. Vociferou o Min. Marco Aurélio a mesma consideração defendida neste trabalho e reconhecida na oportunidade em que a Consulta n. 382 (Resolução n. 20.126/1998) foi respondida: dentro da mesma circunscrição, celebrada uma coligação para a eleição majoritária, partidos adversários nesta eleição não podem formar coligações nas eleições proporcionais. Ademais, nestas, não há a obrigatoriedade de formar a mesma coligação. Nas palavras do Ministro Relator, ipsis litteris:

"Equivale dizer que, formalizadas coligações para as eleições majoritária e proporcional, a elusiva a esta última pode contar com um número menor de partidos, desde que integrados à coligação referente à eleição majoritária. Mais do que isso, a pedra de toque das coligações, considerada a abrangência, está na

\footnotetext{
${ }^{320}$ Cta. n. 1.185/DF, Rel. Min. Marco Aurélio, Rel. p/ Res. Min. Caputo Bastos, Resolução n. 22.161, de 3 de março de 2006.
} 
previsão de observância à circunscrição. A tanto equivale a norma de os partidos políticos, levando em conta a autonomia constitucional que lhes é própria e já referida, podem fazer coligações 'dentro da mesma circunscrição',321".

Marco Aurélio continua seu voto declarando sua opinião contrária à teoria dos conjuntos circunscricionais. Para o Ministro do STF, circunscrição "decorre da área coberta pela eleição". Ademais, como já destacado, a vigência da verticalização ignora sobremaneira características históricas, geográficas e políticas brasileiras. Diante da extensão territorial brasileira, combinada com a adoção do regime federativo em 1889, a vigência da verticalização acabou por ignorar as peculiaridades políticas estaduais ${ }^{322}$.

Continua o Min. Marco Aurélio com sua dura crítica ao princípio da verticalização. Primeiramente, questiona seus pares: "A que serviço está a verticalização no que centraliza a opção de escolha com quem coligar a partir da candidatura à Presidência da República? ${ }^{223}$ ". O Ministro Relator, em acordo com $\circ$ aqui defendido e analisado, chega a asseverar que a verticalização vai contra a "ordem natural das coisas". Seu "caráter moralizador", segundo o Min. Marco Aurélio, é uma "ingenuidade" ${ }^{324}$.

${ }^{321}$ Cta. n. 1.185/DF, Rel. Min. Marco Aurélio, Rel. p/ Res. Min. Caputo Bastos, Resolução n. 22.161, de 3 de março de 2006.

322 O Ministro Marco Aurélio, neste tópico, ressaltou que "a verticalização é algo que, decorrente de certa fase, de certa disputa - e não sei se aqueles que a aplaudiram ainda hoje o fazem -, bate de frente com as realidades nacionais, engessando a política e discrepando da liberdade própria a um Estado Democrático. Sábio foi o Legislador ao delimitar a coligação - e digo coligações - considerada a circunscrição, e aí tem-se, no campo das ideias, no campo do processo eleitoral - repita-se - as circunscrições municipal, estadual e nacional".

${ }^{323}$ Cta. n. 1.185/DF, Rel. Min. Marco Aurélio, Rel. p/ Res. Min. Caputo Bastos, Resolução n. 22.161, de 3 de março de 2006.

${ }^{324}$ Neste tópico, o Ministro Marco Aurélio traz uma indagação: "Será que foram colhidos frutos da novidade interpretativa, ocorrida em 2002, 
A crítica do Relator tem mais dois assentamentos. O primeiro deles diz respeito ao caráter autoritário da verticalização. Fazendo remissão a uma crítica do Ministro aposentado Paulo Brossard ao princípio da coerência das coligações partidárias, Marco Aurélio reitera que critérios como o da verticalização foram adotados "em certa faze do regime de exceção, quando notória a mitigação da vida democrática ${ }^{325 " . ~}$

O segundo ponto alvo da análise crítica do Ministro Marco Aurélio resume-se ao fato de o Supremo Tribunal Federal não ter se pronunciado sobre a questão, ao não conhecer das ações diretas de inconstitucionalidade $n$. 2.626 e 2.628 (vide item 4.5). Por fim, repete o fato de que a verticalização impede que os partidos políticos "levem em conta os interesses setorizados dos partidos, os interesses regionais no que se apresentam distintos de Estado para Estado ${ }^{326 \prime \prime}$.

O Min. Caputo Bastos inaugura a divergência ressaltando que vota contrariamente ao Relator em homenagem ao princípio da segurança jurídica. Aponta Caputo Bastos que até aquele momento não houve nenhum fato superveniente de qualquer natureza a ponto de justificar a mudança de interpretação por parte do TSE. Neste ínterim, ressalta o Ministro a omissão do Legislativo, in verbis:

"O Congresso - já tive oportunidade de dizer isso publicamente - teve tempo para aperfeiçoar a norma ou retornar ao sistema de partidos regionais, se assim o entendesse, o que talvez

\footnotetext{
quando vencidos os Ministros Sepúlveda Pertence e Sálvio de Figueiredo?" .

325 Vide subitem 4.2, que trata da evolução histórica do regime normativo das coligações partidárias no Brasil.

${ }^{326}$ Cta. n. 1.185/DF, Rel. Min. Marco Aurélio, Rel. p/ Res. Min. Caputo Bastos, Resolução n. 22.161, de 3 de março de 2006.
} 
pudesse atender mais convenientemente às mencionadas peculiaridades ou realidades de cada região do País.

Não é o caso.

Diante da omissão legislativa, voluntária ou involuntária, o fato é que não houve mudança no ordenamento jurídico ${ }^{327, "}$

A divergência tem um segundo ponto: a prevalência do dispositivo constitucional que trata do caráter nacional dos partidos políticos. Para o Ministro Caputo Bastos, no conflito entre o caráter nacional e a autonomia partidária, aquele deve ser observado obrigatoriamente, por força do caput do art. 17 da Constituição.

Por fim, o Ministro Caputo Bastos relembra o princípio constitucional da anterioridade eleitoral (art. 16 da CRFB). Para ele, podem ser excluídas da proibição constitucional regras "que não causem impacto significativo nas eleições", desde que "se entenda que venham em benefício da lisura e da normalidade das próprias eleições ${ }^{328 \prime \prime}$.

No que tange à celebração das coligações, Caputo Bastos entendeu que apesar de a deliberação oficial partidária sobre a formação das alianças eleitorais acontecer somente entre 10 e 30 de junho (art. 8०, LE), a impossibilidade dos candidatos em mudar de partidos um ano antes das eleições (art. 18, LPP) "impede que a eventual mudança - legislativa ou interpretativa - produza efeitos ou tenha eficácia retrooperante, ao arrepio de situações consolidadas pelo tempo".

${ }^{327}$ Cta. n. 1.185/DF, Rel. Min. Marco Aurélio, Rel. p/ Res. Min. Caputo Bastos, Resolução n. 22.161, de 3 de março de 2006. Voto do Min. Caputo Bastos.

${ }^{328}$ Cta. n. 1.185/DF, Rel. Min. Marco Aurélio, Rel. p/ Res. Min. Caputo Bastos, Resolução n. 22.161, de 3 de março de 2006. Voto do Min. Caputo Bastos. 
A visão do Ministro Caputo Bastos que manteve a verticalização nas eleições de 2006, portanto, teve como base a segurança jurídica. Paradoxalmente, é forçoso relembrar que a verticalização foi instituída ao arrepio do princípio da anterioridade eleitoral previsto no art. 16 da Constituição. O TSE, na ocasião, ou seja, em fevereiro de 2002, não considerou que as convenções partidárias ocorreriam poucos meses depois, conforme prevê o art. $8^{\circ}$ da Lei das Eleições. Também não considerou que parte do processo eleitoral já havia iniciado com a expiração do prazo final para que os candidatos se filiassem a algum partido, como bem ressaltou o Ministro Caputo Bastos.

Ademais, como já analisado no subitem 4.5.1.1, O TSE, na prática, mudou completamente a visão histórica e até então vigente do real significado do dispositivo constitucional que obriga os partidos políticos a comprovarem seu caráter nacional. O voto do Ministro Caputo Bastos, no entanto, prevaleceu por maioria ${ }^{329}$.

$\mathrm{Na}$ mesma consulta, O PSL apresentou pedido de reconsideração. A agremiação defendeu que: (i) o TSE, no momento em que exarou sua interpretação sobre o art. $6^{\circ}$ da Lei das Eleições, na verdade "invadiu competência reservada à lei"; (ii) O TSE, ao estabelecer a verticalização, não retirou do ordenamento jurídico o alcance do $\$ 1^{\circ}$ do art. $7^{\circ}$ da Lei n. 9.504/97330.

\footnotetext{
329 Votaram com a divergência os seguintes Ministros: Gilmar Mendes, Cezar Peluso, Humberto Gomes de Barros e Gerardo Grossi. O Ministro Cesar Asfor Rocha acompanhou o voto do Min. Marco Aurélio.

330 "Art. $7^{\circ}$ As normas para a escolha e substituição dos candidatos e para a formação de coligações serão estabelecidas no estatuto do partido, observadas as disposições desta Lei.

$\$ 1^{\circ}$ Em caso de omissão do estatuto, caberá ao órgão de direção nacional do partido estabelecer as normas a que se refere este artigo,
} 
O Ministro Relator, Caputo Bastos, ressalta que as regras sobre a verticalização estão vigendo desde 2002, não havendo qualquer ofensa ao $\$ 1^{\circ}$ do art. $7^{\circ}$ da Lei das Eleições. O pedido de reconsideração foi indeferido por unanimidade ${ }^{331}$.

\subsection{Ação Direta de Inconstitucionalidade n. 3.685}

Assim que confirmada a vigência da verticalização nas eleições de 2006 por meio da Resolução n. 22.161 (Consulta n. 1.185, vide item 4.8), houve a promulgação da Emenda Constitucional n. 52, de 8 de março de $2006^{332}$.

Poucos dias depois, o Conselho Federal da Ordem dos Advogados do Brasil, no exercício de sua prerrogativa constitucional (art. 103, VII, CRFB), ajuizou ação direta visando à declaração de inconstitucionalidade do art. $2^{\circ}$ da EC n. 52/2006 $6^{333}$.

A ação direta de inconstitucionalidade foi julgada pelo Pleno do STF em 22 de março de 2006 e, por maioria, declarou a inconstitucionalidade do referido artigo, sendo a ação julgada, portanto, procedente ${ }^{334}$. Assim, a verticalização vigeria nas eleições de 2006 . A Emenda n. 52, que extirpava o princípio da coerência das

publicando-as no Diário oficial da União até cento e oitenta dias antes das eleições".

${ }^{331}$ Cta. n. 1.185/DF, Rel. Min. Caputo Bastos, Resolução n. 22.203, de 16 de maio de 2006.

${ }^{332}$ A tramitação da proposta no Congresso Nacional foi analisada no item 4.6 supra.

333 "Art. $2^{\circ}$ Esta Emenda Constitucional entra em vigor na data de sua publicação, aplicando-se às eleições que ocorrerão no ano de 2002".

${ }^{334} \mathrm{ADI}$ n. 3.685/DF, Rel. Min. Ellen Gracie, j. 22.03.2006. 
coligações partidárias do ordenamento jurídico, porém, teria eficácia a partir de março de 2007.

Neste item, trataremos da argumentação dispendida pelos Ministros do Supremo Tribunal Federal na oportunidade. Faremos também uma análise crítica dessa argumentação, diante de todos os tópicos já expostos sobre - tema neste trabalho. Para tanto, este item será dividido em dois subitens. O primeiro deles tratará da argumentação vencedora, que teve base, principalmente, na vigência do princípio da anterioridade eleitoral insculpido no art. 16 da Constituição. Já o segundo subitem trará a argumentação contida nos votos vencidos, qual seja, contrária à vigência da verticalização das coligações partidárias já nas eleições de 2006.

\subsubsection{Princípio da Anterioridade Eleitoral}

A petição inicial da ADI n. 3.685 ajuizada pelo Conselho Federal da OAB tinha como premissa inicial o fato de a eficácia imediata da Emenda Constitucional n. 52, de 8 de março de 2006, ser inconstitucional, diante do princípio constitucional da anterioridade eleitoral, previsto no art. 16 da Constituição ${ }^{335}$.

Esse princípio já estava previsto no texto original da Constituição de $1988^{336}$. No entanto, a Emenda Constitucional n. 4, de 1993, alterou a redação, que passou a ser esta: "A lei que alterar o processo eleitoral

\footnotetext{
335 "Art. 16. A lei que alterar o processo eleitoral entrará em vigor na data de sua publicação, não se aplicando à eleição que ocorra até um ano da data de sua vigência".

336 O texto original do art. 16 era o seguinte: "A lei que alterar o processo eleitoral só entrará em vigor um ano após sua promulgação".
} 
entrará em vigor na data de sua publicação, não se aplicando à eleição que ocorra até um ano da data de sua vigência". A alteração foi bastante saudada, uma vez que deixou mais claro o fato de que pode haver alteração no processo eleitoral no período anterior a um ano da realização das eleições. Havendo essa alteração, a norma já vige, mas sua eficácia iniciará após transcorrido um ano de sua publicação.

Para O Conselho Federal da OAB, O termo "lei", previsto no texto do art. 16 também prevê as emendas constitucionais. Ademais, a Emenda Constitucional em questão também teria ferdou, reflexamente, os princípios da segurança jurídica (art. 5\%, caput, CRFB) e do Estado Democrático de Direito (art. $1^{\circ}$, caput, CRFB) e atingido, por consequência, cláusulas pétreas.

O Congresso Nacional, oficiado para manifestar-se, defendeu a constitucionalidade do art. $2^{\circ}$ da EC n. 52/2006. Asseverou, resumidamente, que o art. 16 dirige-se ao legislador ordinário, e não ao constituinte reformador. A emenda em questão, portanto, não esbarraria no texto do art. 16 da Constituição.

A Advocacia Geral da União, da mesma forma, manifestou-se pela improcedência da ação direta. Primeiramente, a AGU entendeu que a Emenda em análise tratava de norma de direito partidário, não se cogitando de ter havido alteração das regras do processo eleitoral. Ademais, a AGU infere que se foi possível, em março de 2002, O TSE estabelecer nova interpretação sobre as regras que tratavam das coligações partidárias para as eleições de outubro daquele ano, não havendo qualquer ofensa à segurança jurídica, haveria maior legitimação do Congresso 
Nacional em tratar do tema por meio de emenda constitucional.

A Procuradoria-Geral da República, diferentemente, manifestou-se pela procedência do pedido feito pelo Conselho Federal da OAB. Aduz a PGR que a Emenda não observou o art. 16 da Constituição e, por consequência, desrespeitou também 0 art. $60, \$ 4^{\circ}$, II, da Constituição, que protege o princípio democrático por meio da imutabilidade.

Após discussão de ordem a respeito da possibilidade de a Assembleia Legislativa do Estado do Rio de Janeiro ingressar na ADI sob análise como amicus curiae, a Relatora, Ministra Ellen Gracie, inicia seu voto destacando que o tema tratado na Emenda é eminentemente eleitoral. O próprio texto alterado deixa nítida essa noção, ao se referir à liberdade dos partidos políticos ao adotar critérios de escolha para o "regime de suas coligações eleitorais".

Sem dúvida, é forçoso reconhecer que a argumentação da AGU no tema é frágil. Primeiramente, antes da constitucionalização de regras sobre coligações partidárias advinda com a EC n. 52, a Lei das Eleições, em seu art. $6^{\circ}$, era a única norma ordinária que tratava sobre - tema. Trata-se, sem dúvida, de assunto afeito ao direito partidário, como afirmado pela AGU. Mas não há como reconhecer que regras que tratam de coligações eleitorais alteram também o processo eleitoral ${ }^{337}$.

\footnotetext{
337 No mesmo sentido defendido neste trabalho, a Ministra Ellen Gracie destacou, em seu voto, que "a coligação partidária nada mais é que um dos instrumentos utilizados no processo eleitoral para a composição de alianças com objetivo de participação nas eleições em condições de maior competitividade".
} 
Ademais, Gilmar Mendes e Paulo Gustavo Gonet Branco ressaltam que a expressão "processo eleitoral" contida no art. 16 deve ser interpretada de forma ampla. o processo eleitoral, segundo os autores, versa sobre uma gama complexa de atos que têm como principal objetivo o recebimento e a transmissão da vontade do povo. Esses atos podem ser divididos em três fases: (i) pré-eleitoral; (ii) eleitoral propriamente dita; e (iii) pós-eleitoral. A primeira fase inicia-se na escolha e na apresentação das candidaturas até o final da transmissão da propaganda eleitoral no rádio e na televisão. A segunda fase se dá com a votação (início, realização e encerramento). Já a terceira fase vai da apuração dos votos até a diplomação dos candidatos ${ }^{338}$.

\section{Nesse sentido, a definição trazida pelo Ministro Joaquim Barbosa sobre alteração no processo eleitoral prevista no art. 16 da Constituição é categórica para o bom entendimento sobre o tema:}

"Toda norma com aptidão, ainda que em bases minimalistas, de interferir no exercício da soberania popular, expressa pelo sufrágio universal e voto secreto, seja para impor novos condicionamentos, seja para suprimir os que já vinham sendo tidos como parte integrante do acervo normativo destinado a reger as disputas eleitorais, cai no campo de incidência do art. 16, isto é, altera o processo eleitoral ${ }^{339,}$.

A Ministra Ellen Gracie afirma, em seguida, que não houve intenção do constituinte reformador em fazer com que a EC n. 52/2006 retroagisse para as eleições gerais de 2002. Inicialmente, com acerto, Gracie aponta que se a norma tivesse este objetivo, a conjugação

\footnotetext{
338 Cf. MENDES, Gilmar; BRANCO, Paulo Gustavo Gonet. Curso de direito constitucional. $8^{a}$ ed. rev. e atual., São Paulo: Saraiva, 2013, p. 767 .

${ }^{339}$ ADI n. 3.685/DF, Rel. Min. Ellen Gracie, j. 22.03.2006, Voto do Min. Joaquim Barbosa.
} 
verbal do termo "ocorrer" estaria no pretérito, e não no futuro do presente.

\author{
Ademais, neste tópico, a Relatora \\ ressaltou que não houve intenção do Congresso Nacional em \\ driblar a anterioridade eleitoral determinando a vigência \\ nas eleições de 2002. Para Gracie, há este "erro" no texto \\ da EC n. 52 em virtude das "peculiaridades e dificuldades \\ ínsitas ao processo legislativo brasileiro", conforme \\ trecho a seguir:
}

\begin{abstract}
"Também não me convence o argumento de que tal referência às eleições já consumadas em 2002 serviria para contornar a imposição presente no art. 16 da Constituição Federal, entendendo-se, assim, que, se a nova disposição sobre as coligações já tivesse valido, ainda que de forma fictícia, para o pleito passado, não caberia mais avaliar a ocorrência do decurso de um ano entre a data da vigência da recente alteração normativa e as próximas eleições. Entendo que a atecnia havida, representada pelo acréscimo, ao texto constitucional, de norma que prevê sua futura aplicação a evento já pertencente ao passado há quase 4 anos, teve como principal razão a complexidade, as peculiaridades e as dificuldades ínsitas ao processo legislativo brasileiro, fator somado, ainda, a circunstâncias políticas atuais que reativaram a pretensão de uma célere promulgação de Projeto de Emenda Constitucional que possuía, em sua tramitação final, a mesma redação de substitutivo integrante de relatório aprovado em 03.04.02, na Comissão de Constituição, Justiça e Cidadania do Senado Federal (Parecer 244, de 2002, relator Sen. José Fogaça, DSF 12.02.02) $)^{340,}$.
\end{abstract}

A análise do trâmite da PEC que resultou na EC n. 52/2006 (vide item 4.6) é suficiente para concordarmos com a análise proferida pela Ministra Gracie no assunto. Após rápida aprovação da PEC n. 4/2002 no Senado Federal, a Câmara dos Deputados levou quase quatro anos para aprovar a mudança no texto constitucional. Se a Câmara ou mesmo a Comissão Especial instituída pelo seu então presidente Severino Cavalcanti alterasse a proposta aprovada pelo senado para retirar a referência à vigência do texto já nas eleições de 2002, haveria a obrigatoriedade

${ }^{340} \mathrm{ADI}$ n. 3.685/DF, Rel. Min. Ellen Gracie, j. 22.03.2006. 
de um reexame pelo Senado, o que procrastinaria a tramitação da proposta ${ }^{341342}$.

Assim, a Ministra Gracie chega ao ponto nevrálgico da discussão: a EC n. 52/2006 desrespeitou ou não a anterioridade eleitoral? Para a Relatora, houve clara violação ao art. 16 da Constituição.

Ellen Gracie destaca, inicialmente, que a anterioridade eleitoral é instrumento fundamental para a legitimidade do Estado Democrático de Direito.

O constituinte originário o previu para prevenir o sistema político-eleitoral brasileiros de alterações casuísticas como as verificadas durante o Regime Militar de 1964 (vide itens 3.4.2, 4.3 e 4.4 para o exame da evolução histórica da legislação eleitoral brasileira) . A manipulação dos pleitos por meio da legislação eleitoral é característica histórica inerente ao Brasil. A anterioridade eleitoral, portanto, veio no bojo de garantir

\footnotetext{
341 O Ministro Ricardo Lewandowski entendeu de modo contrário: para ele, foi proposital a previsão de vigência da Emenda nas eleições de 2002 mesmo sendo o texto somente promulgado em 2006, conforme se depreende do trecho a seguir: "Ora, quando de fez com que a Emenda 52 retroagisse os seus efeitos às eleições de 2002 - de resto já travadas, de longa data -, pretendeu-se, na verdade, contornar o princípio da anualidade, contemplado no artigo 16 da constituição, de maneira a que o fim da denominada 'verticalização' sobre a qual não se faz qualquer juízo de valor -, por força da nova redação dada ao parágrafo primeiro do art. 17 da Carta Magna, tivesse vigência já no próximo pleito eleitoral de 2006 (...) Em outras palavras, repita-se, buscou-se, no caso, como se viu, atalhar o princípio da anualidade, dando efeito retroativo à Emenda 52, promulgada em plena vigência do moralizador artigo 16 da Carta Magna". ADI n. 3.685/DF, Rel. Min. Ellen Gracie, j. 22.03.2006, Voto do Min. Ricardo Lewandowski.

342 Em rápido aparte, o Ministro Nelson Jobim enfatiza sua opinião nesse ínterim. Para ele, o fato de a PEC que resultou na EC n. 52/2006 ter sido votada pelo senado em 2002 demonstra que a intenção do Congresso Nacional era "contornar a Resolução votada pelo TSE". Jobim também ressalta que o PDT, agremiação que apresentou a consulta que redundou na verticalização em 2002, ser um dos partidos que na oportunidade defendem o fim da vigência do princípio da coerência das coligações partidárias.
} 
maior segurança jurídica, confiabilidade e legitimidade às eleições brasileiras.

Nesse contexto, a Relatora faz questão de destacar que qualquer espécie normativa pode ter o condão de ferir a anterioridade eleitoral. Assim, uma alteração no Código Eleitoral por meio de lei complementar, uma mudança na Lei das Eleições ou na Lei dos Partidos Políticos, normas de caráter ordinário ou mesmo uma emenda constitucional tratando de tema afeito ao processo eleitoral podem, igualmente, ferir a anterioridade eleitoral. A Ministra Ellen Gracie deixa patente sua opinião sobre o tópico no trecho destacado adiante:

"Ora, se as emendas constitucionais, conforme expressamente previsto na Constituição, são produtos gerados na existência de um processo legislativo, também elas podem, com muito mais gravidade, servir como instrumento de abusos e casuísmos capazes de desestabilizar a normalidade ou a própria legitimidade do processo eleitoral. É forçoso concluir, que em termos de impacto no contexto dinâmico de uma eleição que se aproxima, tanto faz que a alteração se dê por emenda, lei complementar ou lei ordinária, pois a equação das forças políticas que desaguariam, sob a vigência de certas normas, na vitória desta ou daquela possível candidatura poderá sofrer, por fator alheio à vontade popular, completa reformulação ${ }^{343 "}$.

A anterioridade eleitoral é, indubitavelmente, princípio constitucional dirigido ao legislador. A Constituição, a critério do constituinte originário, estabelece limite temporal para a plena eficácia das regras que tratam do processo eleitoral. Dessa forma, a norma que alterar aspecto do processo eleitoral só terá eficácia um ano após o início de sua vigência. Se houver eleição nesse período, prevalece a norma anterior, em respeito à confiança nas regras do jogo eleitoral em andamento.

${ }^{343} \mathrm{ADI}$ n. 3.685/DF, Rel. Min. Ellen Gracie, j. 22.03.2006. 
Assim sendo, a Ministra Ellen Gracie votou pela procedência do pedido do Conselho Federal da OAB, a reconhecer que a expressão "aplicando-se às eleições que ocorrerão no ano de 2002", prevista no texto do art. $2^{\circ}$ da EC n. 52/2006, violava o art. 60, $\$ 4^{\circ}$, IV e o art. 50, caput, LIV e $\$ 2{ }^{\circ}$, ambos da Constituição. Gracie, no que toca à parte remanescente da Emenda, deu interpretação conforme à Constituição, determinando que a eficácia dela só ocorreria após um ano da data de sua vigência.

O Ministro Eros Grau votou com a Relatora, apesar de não reconhecer a anterioridade eleitoral como cláusula pétrea. Neste ponto, Grau restou vencido. A maioria do Pleno entendeu que o art. 16 da Constituição é espécie de cláusula pétrea implícita. Não há a possibilidade, portanto, de o Congresso Nacional aprovar e promulgar emenda constitucional tendente a abolir, direta ou indiretamente, o princípio da anterioridade eleitoral. o STF identificou, no caso em voga, que a EC n. 52/2006 estava abolindo indiretamente o art. 16 da Constituição no que tange às coligações partidárias nas eleições de outubro de 2006 .

A intenção do art. 16 da Constituição de evitar que o legislador (ordinário ou mesmo constituinte derivado reformador) proceda a alterações nas normas eleitorais de forma casuística foi amplamente destacada nos votos dos Ministros do Supremo Tribunal Federal. O Ministro Carlos Ayres Britto destaca outra qualidade do princípio da anterioridade eleitoral: além de prevenir o casuismo, há também a intenção de "estabilizar pelo período mínimo de um ano a legislação de índole processual-eleitoral ${ }^{344 " .}$

\footnotetext{
344 ADI n. 3.685/DF, Rel. Min. Ellen Gracie, j. 22.03.2006. Voto do Ministro Ayres Britto.
} 
Ayres Britto adentra a discussão sobre as possíveis vantagens trazidas pelo advento da verticalização das coligações partidárias, somada ao princípio da anterioridade. Destacou o Ministro que a vigência do art. 16 permite que os partidos políticos tenham um bom período para "costurar alianças de bem maior densidade doutrinária" e "tecer coligações que façam o programático preponderar sobre o meramente pragmático ${ }^{345 "}$.

Já Gilmar Mendes e Celso de Mello destacaram o fato de uma emenda constitucional não ser instrumento legislativo para mudar o espírito da Constituição. Nesse sentido, defendem que o art. 16 tratase de cláusula pétrea implícita, sob a argumentação a ser exposta a seguir.

O Ministro Gilmar Mendes, em seu voto, ressalta que a existência de uma emenda constitucional que altere sua continuidade e sua identidade não pode subsistir. No caso em questão, o art. 16 traz princípio dirigido sim ao legislador, mas também para proteger os cidadãos-candidatos. Na hipótese de se permitir que alterações constitucionais possam ser feitas a qualquer momento do processo eleitoral, os partidos, os candidatos e os próprios eleitores poderiam ser atingidos.

Exemplificamos: a Constituição prevê as datas em que as eleições presidenciais ocorreram, em primeiro e segundo turno, caso este seja necessário. Se fosse possível afastar a incidência do art. 16 por meio de emendas constitucionais, seria forçoso reconhecer que as

\footnotetext{
345 ADI n. 3.685/DF, Rel. Min. Ellen Gracie, j. 22.03.2006. Voto do Ministro Ayres Britto.
} 
datas das eleições presidenciais poderiam ser alteradas poucos dias antes delas ocorrerem. Este fato, indubitavelmente, atingiria não só a legitimidade e a confiabilidade das eleições, mas também a segurança jurídica de todos os atores do processo eleitoral brasileiro.

A anterioridade eleitoral, portanto, trata-se de princípio fundamental para a vigência do Estado Democrático de Direito. Sua revogação, mesmo que reflexa e pontual, como poderia ter ocorrido se a EC n. 52/2006 tivesse eficácia nas eleições de outubro de 2006, pode proporcionar interpretações que, na prática, destruam o sistema político brasileiro desenhado em 1988. Uma Constituição que preveja em seu corpo cláusulas de imutabilidade já determina, explícita ou implicitamente, quais são os seus princípios fundamentais. Gilmar Mendes explicou essa questão em seu voto da seguinte forma, ipsis litteris:

"Otto-Brun Bryde destaca que as ideias de limites materiais de revisão e de cláusulas pétreas expressamente consagradas na Constituição podem estar muito próximas. Se o constituinte considerou determinados elementos de sua obra tão fundamentais que os gravou com cláusulas de imutabilidade, é legítimo supor que nelas foram contemplados os princípios fundamentais ${ }^{346 "}$.

Ao tratar da Emenda em questão, Gilmar Mendes deixa nítido que a EC n. 52/2006 poderia ter ferido o princípio democrático, in verbis:

"Portanto, é preciso analisar em que medida a EC $\mathrm{n}^{\circ}$ 52/2006, ao afastar a aplicação da regra da anualidade do art. 16, restringiu ou anulou o pleno exercício da cidadania política por parte de seus titulares: partidos políticos; cidadãos-candidatos; e cidadãos-eleitores ${ }^{347,}$.

\footnotetext{
346 ADI n. 3.685/DF, Rel. Min. Ellen Gracie, j. 22.03.2006. Voto do Ministro Gilmar Mendes.

347 ADI n. 3.685/DF, Rel. Min. Ellen Gracie, j. 22.03.2006. Voto do Ministro Gilmar Mendes.
} 
Sua resposta é positiva. Mendes acredita que a vigência da EC n. 52 já nas eleições de 2006 feriria a autonomia partidária, uma vez que a igualdade entre as agremiações seria afetada. O Ministro enfatiza que a movimentação em torno do processo eleitoral inicia-se um ano antes do dia de votação. Desde então, são traçadas as estratégias partidárias e individuais de cada postulante. Um ano antes da eleição, o candidato deve definir seu domicílio eleitoral e sua filiação partidária. Mudando-se as regras para as coligações partidárias pouco mais de seis meses antes das eleições de outubro de 2006, haveria afetação imediata às possibilidades de desincompatibilização, às convenções partidárias a serem realizadas em junho e ao período de registro de candidatura ${ }^{348}$.

Na mesma toada, Celso de Mello também destacou que a revisão constitucional serve para alterar o texto da constituição, "mas não para mudar de Constituição ${ }^{349} "$. O constituinte reformador está sempre subordinado ao constituinte originário. Resume-se seu pensamento trazendo à baila o seguinte trecho de seu voto:

"Em uma palavra: o Congresso Nacional não tem poder, nem autoridade, para, a pretexto de reformar o texto constitucional, destruir a própria Constituição, mediante desrespeito frontal àquele conjunto de valores que informa e dão substância à declaração de direitos, dentre os quais avulta, em função de seu sentido histórico, político e social, a necessária observância, pelo Estado, da garantia básica da anterioridade eleitoral ${ }^{350},$.

\footnotetext{
348 Cf. ADI n. 3.685/DF, Rel. Min. Ellen Gracie, j. 22.03.2006. Voto do Ministro Gilmar Mendes. No mesmo sentido, o voto do Min. Nelson Jobim: "As decisões políticas sobre como jogar o jogo começaram a se traçar em outubro do ano passado, no final de setembro ou no início de outubro".

349 ADI n. 3.685/DF, Rel. Min. Ellen Gracie, j. 22.03.2006. Voto do Ministro Celso de Mello.

${ }^{350}$ ADI n. 3.685/DF, Rel. Min. Ellen Gracie, j. 22.03.2006. Voto do Ministro Celso de Mello.
} 
o último a votar favoravelmente à procedência da ação foi o Ministro Nelson Jobim. Ele destacou em seu voto, primeiramente, que o advento da verticalização, em fevereiro de 2002, não trouxe alteração à lei. Tratou-se, simplesmente, de nova interpretação ao art. $6^{\circ}$ da Lei das Eleições, sendo a Resolução n. 21.002, resultado da Consulta n. 715 um mero prosseguimento do decidido na Consulta n. 382. Para tanto, defende de maneira categórica a atuação do STF já estudada nesse trabalho quando do julgamento das ações diretas de inconstitucionalidade n. 2.626 e 2.628, in verbis:

"O fato é que teríamos aqui a possibilidade de afirmarmos claramente que interpretação do Tribunal Superior Eleitoral não é criação de nova lei, mas, sim, a vigência da lei e a leitura da lei legitimamente considerada. E este Tribunal também fez isso quando não conheceu da Ação Direta de Inconstitucionalidade $n^{\circ}$ 2.626, ao dizer que se tratava de matéria de interpretação constitucional ${ }^{351 \%}$.

Analisada toda a argumentação trazida nos votos vencedores, passamos para o estudo da argumentação vencida, ou seja, contrária à vigência da verticalização nas eleições de 2006 e, portanto, favorável a eficácia da EC n. 52 no pleito de outubro de 2006.

\subsubsection{Argumentação contrária à Verticalização}

A arguição constante dos votos vencidos teve como base principal sustentar que a Emenda Constitucional n. 52/2006 não feriu a segurança jurídica eleitoral prevista no art. 16 da Constituição.

Este foi o tom do voto do Min. Sepúlveda Pertence, que relembrou ser contrário à verticalização desde seu advento, no TSE, em fevereiro de 2002. Sua

351 ADI n. 3.685/DF, Rel. Min. Ellen Gracie, j. 22.03.2006. Voto do Ministro Celso de Mello. 
argumentação tocou bastante nos assuntos aqui já estudados no item 4.3.2 - "Argumentos contra a Verticalização" - ao qual fazemos remissão.

Sepúlveda Pertence reconhece que o objeto da emenda trata de processo eleitoral. No entanto, quanto ao possível desrespeito da EC $\mathrm{n}$. 52 à anterioridade eleitoral, Pertence foi categórico. Primeiro, descartou classificar o texto do art. 16 como cláusula pétrea. Assim, poderia a anterioridade eleitoral sofrer temperamentos. O Ministro explica que a segurança jurídica tem a ver com a disposição constitucional que imutabiliza parte de seu próprio texto, mas destaca que o principal aspecto que garante a força do princípio da segurança jurídica é a própria rigidez da Constituição. Para ele, o processo legislativo dificultoso de alteração do texto constitucional é o fato que garante a segurança jurídica da Constituição como um todo, e não a existência de cláusulas pétreas ${ }^{352}$.

Dessa forma, Pertence afirma que não houve qualquer mudança no processo eleitoral com a promulgação da Emenda Constitucional n. 52/2006. O ardoroso adversário da verticalização registra que, na verdade, a emenda em questão apenas deu status constitucional ao art. $6^{\circ}$ da Lei das Eleições. Ao defender esta visão, ainda ironizou:

"A meu ver, constitucionalizou o art. $6^{\circ}$ da Lei $\mathrm{n}^{\circ} 9.504$ (...) apenas se elevou à emenda constitucional o art. $6^{\circ}$ da Lei $\mathrm{n}^{\circ}$ 9.504. Se o ousassem por lei ordinária, provavelmente, alguém sugeriria a prisão preventiva dos congressistas ${ }^{353}$ ”.

${ }^{352} \mathrm{Cf}$. AdI n. 3.685/DF, Rel. Min. Ellen Gracie, j. 22.03.2006. Voto do Ministro Sepúlveda Pertence.

353 ADI n. 3.685/DF, Rel. Min. Ellen Gracie, j. 22.03.2006. Voto do Ministro Sepúlveda Pertence. 
O outro voto contrário foi exarado pelo Ministro Marco Aurélio Mello. Seu voto foi no mesmo sentido tratado pelo Min. Pertence: não houve infringência à anterioridade eleitoral porque não houve alteração do processo eleitoral; a EC n. 52/2006 apenas constitucionalizou o dispositivo ordinário que tratava das coligações partidárias, conferindo "um peso maior ao trato da matéria".

Marco Aurélio ventilou o fato de que o advento da verticalização, em fevereiro de 2002, teria ferido a anterioridade eleitoral. Enfatiza o Ministro, nesse assunto, após fazer longo histórico dos dispositivos legais que trataram das coligações eleitorais, que o TSE, em 1998, em sede da Consulta n. 382 (vide item 4.2.2), já teria interpretado $\circ$ art. $6^{\circ}$ da Lei n. 9.504/1997 sem sequer mencionar a possibilidade da verticalização das coligações partidárias ${ }^{354}$.

O Ministro insiste no fato que a Lei das Eleições menciona a existência de ao menos duas circunscrições nas eleições gerais (nacional e estaduais), não havendo possibilidade de interpretação quanto à primeira englobar as demais. Descarta Marco Aurélio, portanto, a teoria dos conjuntos circunscricionais (vide subitem 4.3.1.3). Seu voto persevera no fato de a verticalização não considerar o princípio federativo nas eleições, dizendo que a obrigação de os partidos manterem

\footnotetext{
354 Nesse sentido, vale trazer o trecho em que o Min. Marco Aurélio ressalta o julgamento da Consulta n. 382 para o caso em vertente: "Senhor Presidente, a prática, em 1998 - não vamos falar de 1996, porque tivemos eleições proporcionais, regidas por uma lei anterior -, qual foi? Entendeu-se que decorreria da Lei $n^{\circ}$ 9.504, de 1997, a denominada verticalização? A resposta é negativa. Concluiu-se que haveria a liberdade tal como consagrada - liberdade em seu sentido maior, não apenas de ir e vir - no artigo $6^{\circ}$ da Lei n ${ }^{\circ} 9.504 / 97$, segundo nossa tradição, após a Carta de 1988".
} 
coerência nas alianças eleitorais equivale a "colocá-los numa camisa-de-força", sem o sopesamento de que

"as forças políticas, neste Brasil continental, consideradas as unidades da Federação, são forças políticas distintas. A realidade encontrada no Acre não é a realidade de São Paulo, de Pernambuco, do Rio de Janeiro ${ }^{355,}$.

Em sua contínua crítica à decisão do TSE de fevereiro de 2002 na qual originou-se a verticalização, Marco Aurélio chega no nó górdio da questão, in verbis:

"De duas, uma: ou estivemos a responder a uma consulta, ou estivemos, naquela assentada, a legislar ${ }^{356 "}$.

Marco Aurélio foi o único magistrado que trouxe este argumento na oportunidade ora em comento. E essa questão continua fundamental: se O TSE, ao tratar o art. $6^{\circ}$ da Lei das Eleições em sede de Consulta ultrapassou os limites constitucionais $e$, na sua atividade interpretativa, criou nova legislação na prática, o atentado à anterioridade eleitoral não ocorreu somente com a promulgação da Emenda Constitucional n. 52/2006, mas também com o advento da verticalização em fevereiro de 2002 .

Nesse ponto, iniciou-se um interessante debate entre os Ministros Marco Aurélio e Gilmar Mendes. Este enfatizou que 0 art. 16 traz limite ao legislador ordinário, constituinte e também ao "intérprete/juiz". Destaca Mendes, porém, que essa questão foi debatida "na assentada desse julgamento do TSE". Mendes, na verdade, refere-se ao julgamento da consulta n. 1.185, que resultou na Resolução que confirmou a vigência da verticalização para as eleições de 2006. Nesse julgamento, o TSE manteve vigente o princípio da coerência nas coligações partidárias

\footnotetext{
355 ADI n. 3.685/DF, Rel. Min. Ellen Gracie, j. 22.03.2006. Voto do Ministro Marco Aurélio.

356 ADI n. 3.685/DF, Rel. Min. Ellen Gracie, j. 22.03.2006. Voto do Ministro Marco Aurélio.
} 
diante do fato que ela vigeu em 2002 e não ter havido nenhuma alteração legislativa no artigo $6^{\circ}$ da Lei $n$. $9.504 / 1997^{357}$.

Marco Aurélio rebate Mendes ao assegurar que a emenda constitucional em questão não alterou nenhuma regra do processo eleitoral, pois, na verdade, apenas deu força constitucional à matéria, conforme se depreende do trecho a seguir:

"a Emenda Constitucional em jogo nada modificou no cenário jurídico. Perdoem-me, modificou, sim. Veio a dar envergadura constitucional a uma matéria já constante da Lei $\mathrm{n}^{\circ}$ 9.504/97. Mais do que isso, veio a cassar - não sei, penso que a cassar com dois esses - a interpretação do Tribunal Superior Eleitoral, tendo em conta o artigo $6^{\circ}$ da Lei $n^{\circ} 9.504^{358,}$.

Por fim, Marco Aurélio traz à baila sua última justificação para a improcedência da ação direta ajuizada pelo Conselho Federal da OAB: deve-se sempre conferir, numa análise de dispositivo constitucional, maior força à interpretação que "consagre a liberdade em seu sentido maior". Nesse sentido, crê o Ministro que a autonomia partidária deve ser ampla, mesmo se comparada com - dispositivo também existente na Constituição que determina que as agremiações partidárias devam ter caráter nacional.

Ao julgar procedente a ação direta, o STF manteve a vigência da verticalização das coligações partidárias para as eleições de 2006. Reconheceu o Supremo que a Emenda enterraria a verticalização para as eleições gerais seguintes (2010). Esse julgamento foi importante por dois fatos. O primeiro deles é que a decisão na ADI $n$. 3.685 tornou-se um leading case na jurisprudência do STF:

\footnotetext{
${ }^{357}$ Para maiores informações, vide item 4.8 supra.

358 ADI n. 3.685/DF, Rel. Min. Ellen Gracie, j. 22.03.2006. Voto do Ministro Marco Aurélio.
} 
foi o primeiro caso em que o Supremo reconheceu que mesmo uma emenda constitucional pode violar o princípio da anterioridade eleitoral.

O segundo fato importante, no contexto deste trabalho, é que pela segunda oportunidade, o STF não se manifestou definitivamente sobre a verticalização em si, tampouco sobre se a decisão do TSE proferida em fevereiro de 2002 respeitou os ditames constitucionais. Nunca saberemos qual seria a decisão do STF, ao menos quanto à verticalização, no que toca à possível exacerbação da função normativa/regulamentar do TSE.

A premissa desse julgamento, apesar de implícita, foi a decisão inicial do TSE em 2002. Para os Ministros que entenderam que a Emenda Constitucional $n$. 52/2006 feriu a anterioridade eleitoral, há, apenas implicitamente, a impressão de que eles concordaram com a decisão do TSE que criou a verticalização. Já os dois Ministros que votaram pela improcedência do pedido do Conselho Federal da OAB já haviam deixado nítida suas opiniões contrárias à verticalização, tanto material como formalmente.

Os Ministros Sepúlveda Pertence e Marco Aurélio, sempre que tiveram oportunidade, rechaçaram a verticalização. Materialmente, ao alegarem que a interpretação da maioria dos Ministros do TSE do art. $6^{\circ}$ da Lei das Eleições foi equivocada. Formalmente, porque defenderam em seus votos que O TSE exacerbou suas competências ao criar nova regra no âmbito das coligações partidárias. 
Quanto aos outros Ministros, não há como responder esse questionamento. Com a exceção de Ellen Gracie e Nelson Jobim, que votaram a favor do advento da verticalização em fevereiro de 2002, podemos somente perceber que outros Ministros trataram da verticalização no sentido material dela. Gilmar Mendes e Cezar Peluso, como Ministros do TSE, confirmaram a vigência dela em 2006 no julgamento da Consulta n. 1.185. No que tange à possibilidade de ultrapassagem dos limites da função regulamentar/normativa pelo TSE, porém, na seara da verticalização, não será possível saber qual seria a decisão do STF .

Finalmente, devemos ressaltar que no julgamento da ADI n. 3.685, é bastante difícil classificar essa decisão como ativista ou não. Nessa análise, temos que ter duas premissas. A premissa que nós defendemos é a de que houve exacerbação por parte do TSE quando da origem da verticalização. Assim, temos que o STF, mais uma vez, chancelou o comportamento ativista do TSE.

A visão defendida nesse trabalho é a de que o TSE ultrapassou sua função normativa/regulamentar e, na ocasião, criou nova lei ao tratar das coligações partidárias. Nesse sentido, a visão do STF de que a Emenda Constitucional n. 52/2006 feriu a anterioridade eleitoral não procede, pois a própria decisão que criou a verticalização teria desrespeitado o comando do art. 16 da CRFB. Gilmar Mendes e Paulo Gustavo Gonet Branco corroboram com nossa opinião, ao afirmarem que a anterioridade eleitoral também deve ser dirigida ao Judiciário, in verbis:

"Embora dirigida diretamente ao legislador, essa norma parece conter âmbito de proteção mais amplo, com o escopo de 
evitar que o processo eleitoral seja afetado por decisões casuísticas de todos os atores do processo, inclusive do Poder Judiciário ${ }^{359 "}$.

A alteração da norma ocorreu em 2002 por força da decisão do TSE, que, na oportunidade, imprimiu verdadeira revolução nas regras então vigentes sobre as coligações partidárias. A Emenda Constitucional n. 52/2006 tem o mesmo espírito da interpretação original do art. $6^{\circ}$ da Lei das Eleições, interpretação esta trazida à baila pelo TSE em 1998 no julgamento da Consulta n. 382. Referida emenda, portanto, apenas teria conferido status constitucional ao art. $6^{\circ}$ da Lei das Eleições, fato que não incidiria em desrespeito à anterioridade eleitoral.

Se tivermos, porém, como premissa que a decisão que originou a verticalização foi correta do ponto de vista formal, a decisão ora em análise é tecnicamente perfeita. Entendemos, da mesma forma explanada no subitem 4.9.1, que emenda constitucional se submete ao princípio da anterioridade eleitoral. Sendo a decisão de fevereiro de 2002 apenas demonstração de nova interpretação do TSE sobre - tema, e não nova norma, a alteração que infringe o art. 16 da Constituição se deu com o advento da Emenda Constitucional n. 52/2006.

\subsection{Consultas formuladas ao Tribunal Superior Eleitoral no ano de 2006}

Após o julgamento da Ação Direta de Inconstitucionalidade $\mathrm{n}$. 3.685 manter a vigência da verticalização das coligações partidárias para o pleito de 2006, já que o advento da Emenda Constitucional n. 52, de 8

\footnotetext{
359 MENDES, Gilmar; BRANCO, Paulo Gustavo Gonet. Curso de direito constitucional. $8^{a}$ ed. rev. e atual., São Paulo: Saraiva, 2013, p. 763 .
} 
de março de 2006, infringiu o princípio da anterioridade eleitoral previsto no art. 16 da Constituição, novas consultas foram apresentadas no TSE para dirimir dúvidas surgidas.

Neste item, demonstraremos que o próprio TSE titubeou na interpretação quanto à demarcação dos limites da verticalização. Primeiramente, o TSE decidiu endurecer a verticalização, poucos dias antes do início das convenções partidárias para as eleições de outubro de 2006. Poucos dias depois, porém, após intensa pressão política, o TSE retrocedeu, mantendo a delimitação interpretativa nos moldes firmados em 2002 .

Assim sendo, este item será dividido em duas partes. A primeira tratará da decisão do TSE em endurecer as regras da verticalização, mudando sobremaneira a interpretação emitida pelo TSE nas Resoluções n. 21.045, $21.046,21.047,21.048$ e 21.049 (vide item 4.4.1 supra). Nelas, O TSE determinou que não havia a obrigação do partido obedecer ao princípio da coerência nas coligações quando não participasse da eleição presidencial.

A segunda parte demonstrará o recuo dado pelo TSE após o endurecimento das regras da verticalização. Decidiu-se, afinal, manter a interpretação exarada em 2002.

\subsection{1. "Enrijecimento" da Verticalização: a Resolução n. 22.242 do TSE}

Confirmada a vigência da verticalização nas eleições de 2006 pelo STF (vide item 4.9 supra), o 
Diretório Nacional do PL - Partido Liberal apresentou a seguinte consulta ${ }^{360}$, in verbis:

"Tendo em vista o entendimento deste Egrégio Tribunal no sentido da manutenção do instituto da 'verticalização', questionase:

Considerando que um determinado partido ' $A$ ' coligue-se com o partido ' $\mathrm{B}$ ', em plano nacional, pergunta-se: em um cenário estadual, levando-se em conta que o partido ' $\mathrm{A}$ ' tenha candidato próprio ao governo do Estado e o partido ' $\mathrm{B}$ ' não possuir candidato próprio neste estado, poderá o partido 'B' celebrar coligações com um partido ' $\mathrm{C}$ ' que não compôs a coligação em nível nacional e nem se coligou com qualquer outro partido em esfera nacional?"

O Ministro Relator, Cesar Asfor Rocha, destaca inicialmente que restou vencido quando da Consulta que confirmou a incidência da verticalização nas eleições de 2006 (vide item 4.8 supra). No mérito, segue seu raciocínio afirmando a jurisprudência do TSE, qual seja, de que um partido que não participa da eleição presidencial (com candidato próprio ou mesmo coligado) tem a liberdade de aliar-se nos Estados-membros e no Distrito Federal com quaisquer outros partidos políticos, participantes ou não da eleição para Presidente da República. A resposta, portanto, foi positiva.

Inicia-se um diálogo ao final do voto do Ministro Relator. O Ministro Marco Aurélio inicia a divergência, apontando que a total liberdade aos partidos que não participam da eleição presidencial faz a verticalização ficar "furada", uma vez que "neste caso, esvazia-se totalmente a verticalização". O Ministro Marco Aurélio sentencia: "Será o faz-de-conta"361".

O Relator, Min. Cesar Asfor Rocha,
ressalta que os "jornais" noticiam que há "um grande

${ }^{360}$ Cta. n. 1.225/DF, Rel. Min. Cesar Asfor Rocha, Rel. p/ Res. Min. Marco Aurélio, Resolução n. 22.242, de 6 de junho de 2006.

${ }^{361} \mathrm{Cta}$. n. 1.225/DF, Rel. Min. Cesar Asfor Rocha, Rel. p/ Res. Min. Marco Aurélio, Resolução n. 22.242, de 6 de junho de 2006. 
partido que está sendo muito procurado pelos principais candidatos", mas "consta que ele não quer se coligar, nacionalmente, para ficar livre e se coligar com quem quiser ${ }^{362 "}$.

Marco Aurélio chega a classificar a possibilidade de um partido que não faz parte da eleição presidencial se coligar com uma agremiação que fez parte da corrida ao Planalto (coligado ou com candidato próprio) de "concubinato". Continua seu raciocínio, ao dizer que o voto do Relator "esvazia totalmente $\circ$ que decidido pelo Supremo". Por fim, o Ministro do Supremo, exercendo a Presidência do TSE naquele momento, ressalta que votou pelo provimento da ADI n. 3.685 no Supremo, pois a "Emenda, sob minha óptica, teria dado envergadura maior ao trato da matéria tal como contida na Lei n $9.504 / 97$ e teria cassado simplesmente uma interpretação deste Tribunal 363". Assim, o Ministro Marco Aurélio respondeu à consulta negativamente.

Para esclarecimentos, o Min. Ayres Britto questiona se ainda haveria a possibilidade de "aliados no plano nacional" serem "adversários no plano estadual". Marco Aurélio responde que o intuito da verticalização é afastar a "promiscuidade eleitoral". Assim, acompanharam a divergência iniciada pelo Ministro Marco Aurélio os seguintes julgadores: Cezar Peluso, Ayres Britto, José Delgado, Caputo Bastos e Gerardo Grossi. O Relator Cesar Asfor Rocha restou vencido. A ementa da decisão foi redigida da seguinte forma:

\footnotetext{
362 O Ministro Cesar Asfor Rocha refere-se, muito provavelmente, ao PMDB. Mesmo sendo o maior partido do Brasil na época (segunda maior bancada na Câmara dos Deputados, maior bancada no Senado, maior número de prefeitos e governadores), o partido resolveu não participar da eleição presidencial em 2006.

${ }^{363}$ Cta. n. 1.225/DF, Rel. Min. Cesar Asfor Rocha, Rel.p/ Res. Min. Marco Aurélio, Resoluçãon. 22.242, de 6 de junho de 2006 .
} 
"Verticalização - A verticalização é conducente à observância, na base, da coligação feita a nível nacional".

Esta decisão endureceu a interpretação do princípio da coerência das coligações partidárias. A partir de então, os partidos que participassem da eleição presidencial não poderiam ser adversários em nenhuma eleição estadual ou distrital. Ademais, o partido que decidisse não participar da eleição presidencial também não poderia formar coligação nos Estados-membros ou no Distrito Federal com nenhum partido participante da eleição nacional.

Nosso entendimento e de que a segunda parte da decisão está correta, conforme já apontado no item 4.4.1 supra. Não havia sentido em não exigir qualquer coerência dos partidos que não participassem da eleição presidencial.

O TSE, na Consulta n. 715/DF, decidiu interpretar o art. $6^{\circ}$ da Lei das Eleições no sentido de que - caráter nacional dos partidos (art. 17, inciso I, CRFB) significava que nas eleições gerais, os partidos participantes de coligação no pleito presidencial não poderia coligar-se nos Estados e no Distrito Federal com nenhum adversário seu na eleição nacional. A coerência, portanto, seria exigida entre a eleição nacional e as eleições estaduais.

Assim, no nosso entender, vigendo a verticalização, os partidos não poderiam coligar-se com quaisquer partidos que não estivessem dentro de sua aliança nacional, mesmo com uma agremiação que não participasse da eleição presidencial, sob pena de a verticalização realmente ficar "furada". No entanto, sob a égide do 
princípio da coerência das coligações, não vemos qualquer objeção legal ou constitucional para que partidos coligados nas eleições presidenciais possam apresentar candidaturas isoladas nos Estados-membros ou no Distrito Federal. Veremos, no subitem seguinte, que a eficácia desta decisão surpreendente durou muito pouco.

\subsubsection{Novo "afrouxamento" da Verticalização: as Resoluções $\mathrm{n}$. 22.244 e 22.248 do TSE}

Apenas dois dias depois da decisão na Consulta n. 1.225/DF, que resultou na Resoluçãon. 22.242, - TSE se debruçou novamente sobre a mesma consulta.

O consulente, Partido Liberal, apresentou pedido de reconsideração, com as seguintes ressalvas: (i) sua intenção ao apresentar a consulta era o de "confirmar que as regras aprovadas por este Tribunal nas eleições de 2002 continuavam a vigorar nas eleições de 2006"; (ii) a Resolução n. 22.242 contrariaria "entendimentos desta mesma Corte, além de contrariar também a legislação eleitoral vigente ${ }^{364 \prime \prime}$.

O Min. Marco Aurélio, novo relator, inicia seu voto destacando novamente sua opinião de que admitir numa coligação estadual partido que não participou da eleição estadual tornaria a verticalização "furada", implicando em "verdadeiro concubinato". Ressalta Marco Aurélio que ao reexaminar a decisão do STF na ADI n. 3685, houve o afastamento da Emenda Constitucional n. 52 pela "premissa de que a emenda alterava a regência da matéria para se ter liberdade maior dos partidos políticos quanto

\footnotetext{
${ }^{364}$ Cta. n. 1.225/DF, Rel. Min. Marco Aurélio, Resoluçãon. 22.244, de 8
} de junho de 2006 . 
às coligações" em desrespeito à anterioridade eleitoral (art. 16, CREB).

Sustenta o Presidente do TSE que a Emenda, na verdade, cassou a interpretação da Corte Eleitoral decorrente, principalmente, da Consulta n. 766, decorrendo na potencialização, "a não mais poder", da autonomia partidária. Quedou-se vencido, ressalta.

Reconhece, no entanto, que voto proferido pelo Ministro Asfor Rocha dois dias antes estava correto. Pondera, inicialmente, que por se tratar de processo administrativo, é possível revisar o decidido a qualquer momento. Assim, conclui que "se o partido não lançou candidato à eleição presidencial, viável na base é a coligação com aquele que apresentou, a tal nível, candidato ${ }^{365 \prime \prime}$.

- Ministro Cezar Peluso adianta-se pelo não convencimento com o novo entendimento exarado por Marco Aurélio, pois entende que "a resposta da Corte na assentada passada é absolutamente sustentável". Ressalta, porém, que reconsidera seu voto por aplicar o princípio da segurança jurídica, uma vez que a Resolução n. 22.242 transformou-se em

"um fator de insegurança, muito bem demonstrado pelo vivíssimo alvoroço que causou no ambiente político, em ofensa direta ao art. 16 da Constituição da República”. (grifos nossos).

o Min. Ayres Britto inicia seu voto defendendo a decisão anterior: "Ortodoxa, pura, depurada, consistente nos seus elementos intrínsecos, lógicos. Vamos

\footnotetext{
${ }^{365}$ Cta. n. 1.225/DF, Rel. Min. Marco Aurélio, Resoluçãon. 22.244, de 8
} de junho de 2006 . 
dizer em linguagem mais coloquial: uma verticalização pra valer"

Ao reconhecer que as decisões exaradas pelo TSE em 2002 tiveram caráter interpretativo, e não normativo (vide item 4.5 .1 supra) ${ }^{366}$, Ayres Britto conclui que a decisão que resultou na Resolução n. 22.242 "é francamente aplicável à eleição atual", pois "se as resoluções todas tiveram caráter interpretativo, a mais recente prevalece sobre as mais antigas".

Reconhecendo que a Resolução n. 22.242 robustecia o princípio da verticalização, mas, ao mesmo tempo, ressaltando que este princípio só vigeria na eleição de outubro de 2006, uma vez que a partir deste momento a EC n. 52/2006 teria eficácia, o Ministro Ayres Britto faz interessante indagação, ipsis litteris:

"Seria mais coerente com o ordenamento jurídico fortalecer esse instituto agonizante, com o risco de instabilizar as regras do jogo eleitoral, ou, em homenagem ao princípio da segurança jurídica, optar pela continuidade do vigor das resoluções que presidiram as eleições de 2002 e, até terça-feira última, estavam na plenitude de sua eficácia? ${ }^{367 "}$

Segue seu pensamento para, na mesma toada do Min. Cezar Peluso, confirmar seu entendimento verberado na Resolução n. 22.242, porém deferir o pedido de reconsideração do $\mathrm{PL}$ a a plicar o princípio da segurança

\footnotetext{
366 "Segundo marco teórico: as decisões de 2002 não tiveram caráter normativo - e V. Exa. traz à baila, procedentemente, decisão do Supremo Tribunal Federal nesse sentido -, elas tiveram caráter interpretativo. Na verdade, desataram do sistema jurídico, da Constituição e, mais de perto, do art. $6^{\circ}$ da Lei $n^{\circ} 9.504 / 97$, comandos que já estavam no Ordenamento. Assim, tiveram natureza interpretativa, não normativa, e puderam construir interpretativamente o princípio da verticalização, já atribuído no Ordenamento". Cta. n. 1.225/DF, Rel. Min. Marco Aurélio, Resoluçãon. 22.244, de 8 de junho de 2006, voto do Min. Ayres Britto.

${ }^{367}$ Cta. n. 1.225/DF, Rel. Min. Marco Aurélio, Resoluçãon. 22.244, de 8 de junho de 2006, voto do Min. Ayres Britto.
} 
jurídica, com base no princípio constitucional da anterioridade eleitoral (art. 16 da CRFB), in verbis:

"No plano da validade, que é um dos atributos da norma jurídica, eu não teria dúvida em dizer que foi a melhor decisão. No plano da eficácia, porém, a imediata aplicabilidade da resolução parece contrariar o espírito do art. 16, que nada mais significa senão consagrar um valor jurídico. Há um bem jurídico fundamental veiculado pelo art. 16: a fixidez legislativa. Ou seja, eleição é um processo de renovação dos quadros dirigentes do país que corresponde a uma excitação cívica saudabilíssima, necessária, e envolve três protagonistas centrais que precisam conhecer por antecipação as regras do jogo: os partidos políticos - isoladamente ou coligados -, os candidatos e os eleitores.

Assim, o art. 16 da Constituição cumpre a função de conferir segurança ao jogo eleitoral, assumindo a compostura de devido processo legal $^{368 \%}$.

No mesmo sentido, votaram os Ministros

Cesar Asfor Rocha, José Delgado - que destacou o "engrandecimento" do TSE na aplicação do princípio da segurança jurídica -, Gerardo Grossi e Marcelo Ribeiro.

Este último não participou da decisão que resultou na Resolução n. 22.242, mas manifesta-se a favor de seu teor. Entretanto, neste momento, também aplica o princípio da segurança jurídica ao caso. Por fim, esclarece - Min. Ayres Britto que esta decisão também atende ao princípio da proporcionalidade em sentido estrito, ao afirmar que, no caso, "o que se ganharia com o fortalecimento da verticalização se perderia com mais compleição, com mais envergadura, no plano do princípio da segurança jurídica ${ }^{369 " \text {. }}$

Em nosso modesto ver, o fato de o TSE ter alternado tantas vezes, somente em 2006, de opinião demonstra não só a polêmica que o assunto gerou, mas também a fragilidade dos argumentos pró-verticalização. Como já

\footnotetext{
${ }^{368}$ Cta. n. 1.225/DF, Rel. Min. Marco Aurélio, Resolução n. 22.244, de 8 de junho de 2006, voto do Min. Ayres Britto.

${ }^{369}$ Cta. n. 1.225/DF, Rel. Min. Marco Aurélio, Resolução n. 22.244, de 8 de junho de 2006, voto do Min. Ayres Britto.
} 
demonstrado nos itens anteriores deste capítulo, o advento da verticalização não só se tratou de uma decisão ativista, mas também de uma decisão em que a argumentação vencedora é bastante frágil. Entendemos, portanto, que a confusão gerada pelo TSE em junho de 2006 somente demonstra quão falha foi sua decisão original no tema.

Na mesma data, O TSE tratou de outra consulta, apresentada pelo deputado federal Eduardo Cunha (PMDB/Rio de Janeiro), com o seguinte conteúdo:

"Partidos políticos integrantes de uma coligação nacional podem isoladamente nos estados lançarem candidatos à governador e/ou senador ou são obrigados a terem um único candidato a governador e/ou senador? $?^{370}$,

O Ministro Relator, Ayres Britto, ressaltou que o questionamento já havia sido apreciado por ocasião da Consulta n. 760 (Resolução n. 21.047), e respondeu positivamente, sendo seguido por todos os outros magistrado, "no sentido de que o partido coligado em nível nacional pode concorrer isoladamente nos estados para os cargos de governador e senador ${ }^{371 "}$.

\subsection{Resolução n. 23.200 do TSE (Consulta n. 1.735): o reconhecimento do fim da Verticalização}

Aprovada a Emenda Constitucional n. 52 e passada a eleição de 2006, o presidente nacional do PSL (Partido Social Liberal) apresentou a última consulta acerca da possível vigência da verticalização das

\footnotetext{
${ }^{370}$ Cta. n. 1.304/DF, Rel. Min. Ayres Britto, Resolução n. 22.248, de 8 de junho de 2006 .

${ }^{371}$ Cta. n. 1.304/DF, Rel. Min. Ayres Britto, Resoluçãon. 22.248, de 8 de junho de 2006 .
} 
coligações partidárias ${ }^{372}$. A consulta consistiu no seguinte questionamento:

"Poderá haver a regra da verticalização partidária para o pleito eleitoral de 2010, através de resolução a ser expedida por esta E. Corte Eleitoral, ou será respeitada a regra de total liberalidade para os partidos políticos adotarem o regime de coligações sem vinculação entre as candidaturas em âmbito nacional, estadual, distrital e municipal, como determina o $\S 1^{\circ}$ do artigo 17 da Constituição Federal de 1988?".

O Ministro Relator, Félix Fischer, confirmou brevemente a interpretação dada pelo Supremo Tribunal Federal quando do julgamento da ADI n. 3.685, qual seja: a obrigatoriedade de obediência ao princípio da coerência nas coligações, vigente nas eleições de 2002 e 2006, estava extirpado do ordenamento jurídico nacional com - advento da Emenda Constitucional n. 52/2006.

A verticalização, conforme decisão do STF na ADI supra citada, só foi aplicada nas eleições de 2006 , como já analisado no item 4.9 supra, em respeito ao princípio da anterioridade eleitoral insculpido no art. 16 da Constituição. Assim, o Ministro Fischer respondeu a consulta ao dizer que a redação do $\$ 1^{\circ}$ do art. 17 da CRFB, disposição alterada pela EC n. 52/2006, "incidirá sobre as eleições de 2010".

O TSE, por unanimidade, concordou com 0 Ministro Relator ${ }^{373}$. Atestou-se, definitivamente, o fim da verticalização das coligações partidárias no sistema político-eleitoral brasileiro.

${ }^{372}$ Cta. n. 1.735/DF, Rel. Min. Félix Fischer, Resolução n. 23.200, de 17 de dezembro de 2009.

373 Votaram com o Relator os seguintes Ministros: Ayres Britto, Cármen Lúcia, Ricardo Lewandowski, Fernando Gonçalves, Marcelo Ribeiro e Arnaldo Versiani. 


\subsection{Análise das decisões sobre a verticalização das coligações partidárias sob a ótica do fenômeno do ativismo judicial}

Após todos os argumentos utilizados pelos Ministros do TSE e do STF virem à tona no caso da verticalização, fica a pergunta: houve ativismo judicial ou não por parte dos referidos tribunais? A nossa resposta é positiva. Primeiramente, demonstraremos que as outras decisões estudadas nesta tese têm caráter ativista. Após, passaremos para uma análise conclusiva sobre a argumentação trazida pelos Ministros quando do julgamento da verticalização, bem como se nestas decisões a atividade do TSE e do STF devem ser consideradas ativistas.

No que tange à atividade ativista, podemos concluir que O TSE e O STF, na seara políticoeleitoral, têm trazido à tona vários exemplos de exercício de ativismo judicial.

Primeiramente, no caso da proporcionalidade do número de cadeiras nas Câmaras Municipais, O STF ignorou a possibilidade de o Congresso tratar do assunto ou até das próprias Câmaras Municipais legislarem sobre o tema. O Supremo preferiu delegar ao TSE a competência de garantir a eficácia de sua decisão. Neste caso, chama muito a atenção o fato de a decisão do STF ter sido proferida em sede de recurso extraordinário, decisão da qual se gera efeitos inter partes. Ao decidir o "caso Mira Estrela", O STF alterou a jurisprudência consolidada vigente, ignorou a possibilidade de o Congresso ou das Câmaras Municipais legislarem sobre o assunto e delegou competência ao TSE para normatizar $\bigcirc$ assunto e, assim, garantir a eficácia de sua decisão para todos os Municípios brasileiros. Depreende-se que várias das dimensões trazidas 
no ensinamento de Bradley Canon foram ultrapassadas somente neste caso concreto (vide item 2.2 supra).

No caso da fidelidade partidária, não houve diferença. Após a decisão do TSE em sede de consulta mudando a jurisprudência consolidada sobre o tema, o STF foi provocado a se manifestar por meio de três casos concretos diferentes. Ao decidir manter a nova interpretação exarada pela corte Eleitoral, e novamente em sede de lide que geraria, em tese, apenas efeitos inter partes, o Supremo novamente deixou de lado o órgão constitucionalmente competente para legislar sobre o assunto (Congresso Nacional, conforme arts. 22, I, c/c art. 48, caput, ambos da CRFB). Delegou, como na discussão sobre a proporcionalidade do número de cadeiras nas Câmaras Municipais, ao TSE a competência de normatizar o assunto, inclusive no que tange ao procedimento processual para a prestação da tutela jurisdicional envolvendo o mandato eletivo do político infiel. Provocado em sede de ação direta, O STF mencionou que esse mecanismo ativista tratava-se de medida excepcional, sendo eficaz somente até o Congresso legislar sobre o assunto. Mais uma vez, podemos perceber que a lição de Canon é bastante útil para determinarmos que a atividade do TSE e do STF em relação à fidelidade partidária foi ativista.

A questão da certidão da quitação eleitoral é mais um exemplo da atividade ativista da Justiça Eleitoral. O TSE mudou sua interpretação diversas vezes sobre o tema, pondo em risco o princípio da segurança jurídica nas eleições brasileiras. Essa indecisão poderia causar efeitos graves, uma vez que dependendo da orientação do TSE que estivesse vigendo sobre o tema, inúmeros candidatos perderiam essa condição e, na prática, não 
poderiam concorrer, alterando-se profundamente o quadro eleitoral. Foi somente com a alteração da Lei das Eleições no tema por parte do Congresso Nacional que a questão, após muita polêmica e "idas e vindas" dentro do Congresso, foi pacificada.

Por fim, cabe a nós, nesse momento, demonstrar o escopo desse trabalho: as decisões exaradas pelo TSE e pelo STF, no bojo da verticalização das coligações partidárias, também podem ser classificadas como ativistas.

A decisão que originou a verticalização das coligações partidárias (Resolução n. 21.002/2002) adveio do exercício da função consultiva do TSE prevista no art. 23 do Código Eleitoral. Diante do fato de que a posição doutrinária dominante é de que decisões do TSE em caráter consultivo não possuem caráter vinculante (vide item 3.3 supra) ${ }^{374375}$, a Corte Eleitoral incluiu sua nova interpretação sobre as coligações partidárias em Resolução que tratava das normas gerais para as eleições de 2002, esta sim com força normativa (Resolução n. 20.993/2002).

\footnotetext{
${ }^{374}$ Nesse sentido, podemos citar Suzana de Camargo Gomes ("A competência da Justiça Eleitoral". In: Revista Brasileira de Direito Constitucional, n. 3, jan./jun. 2004, p. 717), que ressalta o "caráter pedagógico" da decisão proferida em sede de consulta. Corroboram com a ausência de força normativa às decisões em sede de consulta Manoel Carlos de Almeida Neto (In: O poder normativo da Justiça Eleitoral, p. 224) e Eduardo Silva da Silva (In: "Jurisdição e positivismo jurídico: breves reflexões sobre o procedimento de consulta na Justiça Eleitoral", p. 437).

${ }^{375}$ A jurisprudência do STF é uníssona nesse sentido, qual seja, de não conferir caráter normativo/vinculante às decisões do TSE em sede de Consulta. Podemos citar como exemplo a ADI n. 1.805-MC/DF, cujo pedido cautelar foi julgado em 26.03.1998. No julgamento, ficou consignado pelo Ministro Néri da Silveira que "resposta a consulta não obriga quer o consulente, quer terceiros, nem dela coisa julgada resulta, força é entender não caracterizar-se dita Resolução como ato normativo".
} 
Esse movimento já demonstra a impetuosidade do TSE na questão. Poucos dias após de exarar decisão sem força vinculante no tema, ou seja, os partidos políticos não incidiriam em ato ilícito caso celebrassem coligações contrárias ao princípio da coerência, o TSE, sem oitiva dos interessados, conforme determina o art. 105 da Lei das Eleições, incluiu a verticalização das coligações em Resolução com força normativa.

Ademais, materialmente, a decisão que originou a verticalização das coligações partidárias também foi resultado de uma atividade ativista da Justiça Eleitoral. O princípio da anterioridade eleitoral determina que se houver alteração em lei que trata de questões concernentes ao processo eleitoral num período inferior a um ano da data da eleição, a aplicação dessa alteração só gerará efeitos para a eleição seguinte. No momento em que o TSE incluiu em Resolução de caráter normativo sua nova interpretação, incidiu em alteração do processo eleitoral. Destaque-se: tal fato ocorreu em fevereiro de 2002, ou seja, menos de um ano antes da eleição de outubro daquele ano. Não há dúvidas de que houve alteração normativa no que tange à verticalização. Na eleição de 1998, não houve a vigência do princípio da coerência das coligações partidárias. Em 2002, por meio de Resolução de caráter normativo, foi incluída essa exigência.

Na mesma toada, O TSE utilizou-se, para justificar sua nova interpretação, de dois argumentos, a nosso ver, frágeis: o caráter nacional dos partidos políticos e a teoria dos conjuntos circunscricionais combinada com o conceito de "parâmetro inafastável". A primeira referência, como analisado anteriormente, se refere à impossibilidade constitucional de ser registrado 
partido político de caráter regional ou local. Ademais, a Lei dos Partidos Políticos prevê os requisitos para o atendimento do dispositivo constitucional de caráter nacional dos partidos em somente um momento: o registro no TSE.

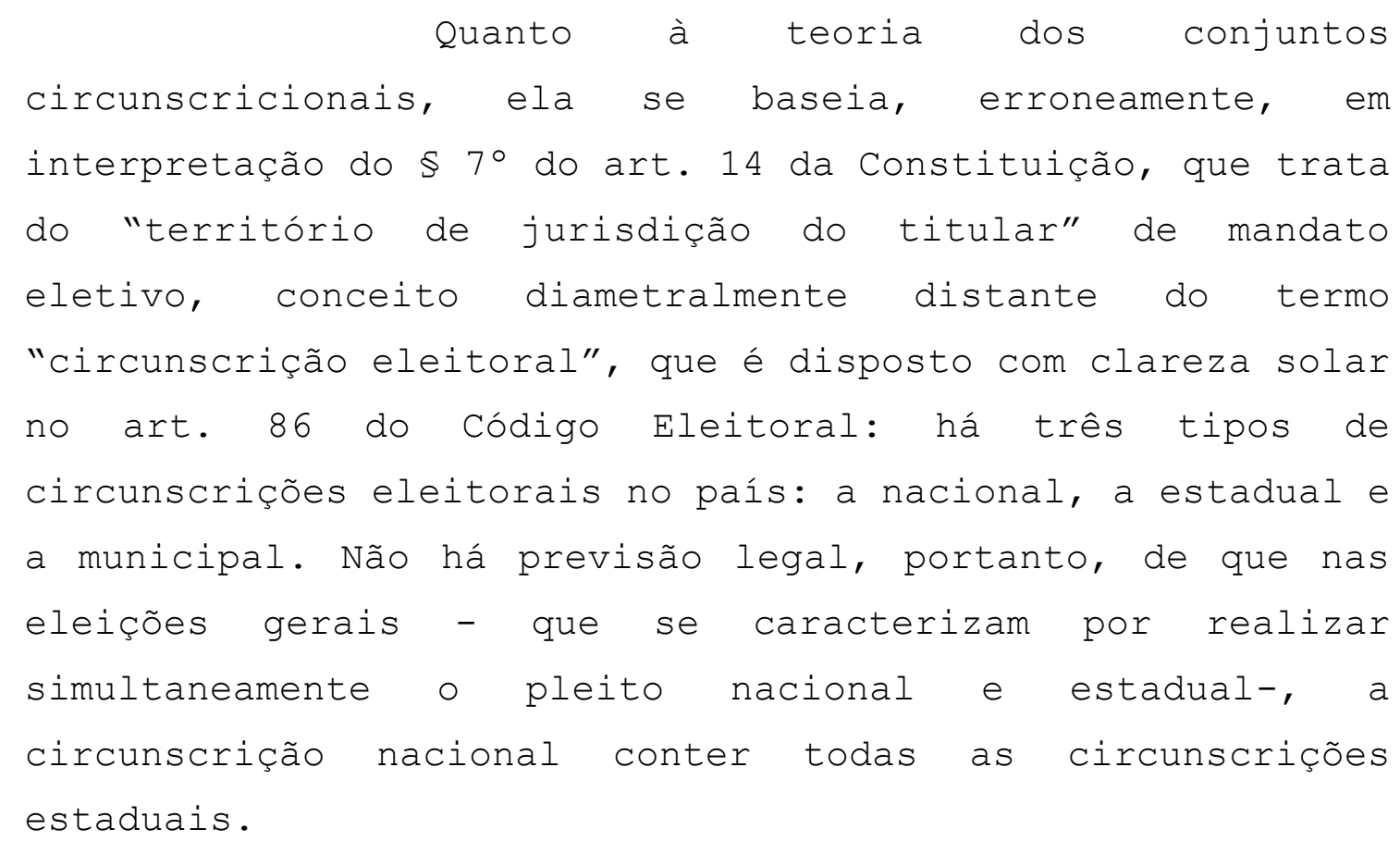

A decisão que originou a verticalização também feriu o princípio constitucional da autonomia partidária. A Lei dos Partidos Políticos também a prevê e, no que tange às coligações, é nítida ao determinar que decisão de diretório hierarquicamente superior que imponha diretrizes para a formação das alianças eleitorais nas demais circunscrições tem o condão de anular determinação de diretórios inferiores na hipótese de desrespeito a essas diretrizes. Desse modo, percebe-se que a LPP previa a possibilidade de coligações não verticalizadas, sendo assunto interna corporis dos partidos políticos a exigência de verticalização ou não. Se a lei prevê que a coerência das coligações é tópico a ser tratado internamente pelo 
partido, dentro de sua autonomia constitucional, como pode o TSE interpretar que a lei prevê a verticalização?

A lição de Bradley Canon é útil para demonstrar que a verticalização foi mais um exemplo de julgamento de caráter ativista no Brasil. A decisão que originou a verticalização, como vimos anteriormente, mudou - entendimento judicial sobre o tema. O julgamento da Consulta n. 382, ao interpretar $\circ$ art. $6^{\circ}$ da Lei das Eleições, sequer cogitou a hipótese de existir verticalização. Canon ensina que o fenômeno do ativismo pode ser encontrado no grau em que o Tribunal altera decisões e doutrinas pretéritas.

Ao alterar o nítido espírito da Lei das Eleições no seu art. $6^{\circ}$, espírito esse reconhecido pelo conceito de "parâmetro inafastável" concebido pelo Ministro Néri da Silveira quando Relator da Cta. n. 382, qual seja, de que há verticalização das coligações somente dentro da mesma circunscrição, houve a hipótese prevista na terceira dimensão do pensamento de Canon (fidelidade interpretativa): a interpretação nova que originou a verticalização é contrária a claras intenções dos elaboradores do texto normativo.

O primeiro julgamento do STF sobre o tema também tem caráter ativista. Ao afastar o julgamento do mérito das duas ações diretas de inconstitucionalidade ajuizadas, o supremo incidiu em atividade ativista, pois avalizou a decisão ativista do TSE. Ademais, esta decisão ignorou o fato de o ato normativo impugnado ser $0 \$ 1^{\circ}$ do at. $4^{\circ}$ da Resolução n. 20.993/2002, ou seja, ato de caráter normativo, e não a Resolução n. 21.002/2002 que originou a verticalização, essa sim de caráter infralegal e, por 
conseguinte, inviável sofrer controle de constitucionalidade.

Após a confirmação pelo TSE da vigência da verticalização nas eleições de 2006, o Congresso Nacional promulgou emenda constitucional tratando do tema. Provocado novamente por meio do sistema de controle de constitucionalidade concentrado, O STF manifestou-se pela continuidade da verticalização nas eleições de 2006 . Essa decisão pode ser considerada ativista por se tratar da sexta hipótese trazida por Bradley Canon (existência de formuladores alternativos de política pública), qual seja: ao afastar a eficácia da EC n. 52/2006, O STF desprezou as considerações de outro agente constitucional sobre a questão.

Pode-se até alegar que o TSE, no momento que originou a interpretação pela vigência da verticalização, estava no exercício de suas funções atípicas (consultiva e, no segundo momento, normativa), e não no cumprimento de sua competência jurisdicional. A tese aqui defendida é a de que estas competências, na prática, acabam se confundindo.

Primeiramente, devemos reconhecer que os membros do TSE são, exercendo quaisquer das funções constitucionais ou legais previstas para a máxima corte eleitoral do país, efetivamente magistrados, com todos direitos e prerrogativas decorrentes do exercício dessa função.

Ademais, o instituto da Consulta na Justiça Eleitoral, na verdade, tem sofrido um processo de desnaturação. De mero instrumento administrativo de caráter 
pedagógico com o objetivo de resolver questões abstratas, a consulta passou a ser, com o decorrer dos anos, o instrumento utilizado pelos partidos políticos para tentar impor seus interesses particulares. Eduardo Silva da Silva corrobora com essa opinião, ao afirmar que

"é inverossímil que os partidos políticos e as autoridades públicas, em pleno ano eleitoral, premidas por uma série de ocupações e pressões, possam divagar e pleitear, junto à Justiça Eleitoral, pronunciamentos que não lhe sejam imediatamente necessários. O fato de não se denominar especificamente os interessados (ou os interesses), não torna, em absoluto, a consulta em abstrato, mas apenas lhe empresta um ar de abstração".

E completa o raciocínio, destacando a

dificuldade do TSE ao tratar de questões supostamente em abstrato, in verbis:

"Desde já, é necessário ressaltar que esta aludida abstração torna ainda mais árdua a tarefa do tribunal que irá se pronunciar sobre o caso em exame. Acostumado a referenciar-se no concreto, manifestar-se-á vinculando-se, ao menos formalmente, a uma questão que não lhe foi apresentada na sua forma integral ${ }^{376, "}$.

O abuso do TSE no exercício das suas atividades normativa e consultiva, da mesma forma, pode ser adaptado ao ensinamento de Elival da Silva Ramos. O autor defende que no momento em que o Poder Judiciário, no exercício de sua função jurisdicional, em desrespeito ao princípio constitucional da separação dos Poderes, há atividade ativista.

Sendo a Justiça Eleitoral um ramo do
Poder Judiciário contemplado com funções sui generis,
entendemos que a lição de Elival Ramos no sentido de que no
momento em que o TSE resolve "litígios de feições
subjetivas (conflitos de interesse) e controvérsias

376 SILVA, Eduardo Silva da. "Jurisdição e positivismo jurídico: breves reflexões sobre o procedimento de consulta na Justiça Eleitoral". In: Revista Forense, v. 350, abr./mai./jun. 2000, p. 437. 
jurídicas de natureza objetiva (conflitos normativos) 377 ", mesmo no exercício de suas competências atípicas, há a atividade ativista.

Desse modo, no momento em que o TSE incluiu, após julgar a Cta. n. 715 e interpretar o art. $6^{\circ}$ da Lei n. 9.504/97, a nova interpretação que gerou a verticalização das coligações partidárias em Resolução de caráter normativo, indubitavelmente ultrapassou sua competência constitucional, desrespeitando a separação de Poderes (tratava-se, no caso, de competência do Congresso Nacional legislar sobre o assunto) e criando nova norma ignorando, por conseguinte, a interpretação doutrinária mais balizada no tema e também sua própria jurisprudência

377 RAMOS, Elival da Silva. Ativismo judicial: parâmetros dogmáticos. São Paulo: Saraiva, 2010, p. 129. 


\section{Considerações finais}

Esta tese consistiu, fundamentalmente, na narração de um fato histórico para o direito constitucional brasileiro. Uma história de ativismo judicial na Justiça Eleitoral. Não há consenso acerca do que seja ativismo, tampouco sobre seu valor para a sociedade. Este trabalho, no entanto, já tem seu valor por ser o primeiro trabalho a esmiuçar todos os argumentos - e expor as contradiçõespresentes em diversas decisões emanadas pelos mais diversos magistrados no tema da verticalização das coligações partidárias.

Esta tese foi além: mesmo havendo dificuldade de conceituação do fenômeno, identificamos que, no caso concreto do advento do princípio da coerência das coligações partidárias, houve atividade ativista por parte do Judiciário. Ao utilizar o ponto mais comum na doutrina no momento de definir o fenômeno do ativismo - a extrapolação de competência por parte do Judiciário -, a tese tem um ponto adicional, ao demonstrar como esse fenômeno ocorre.

Interessante notar que essa definição básica é utilizada tanto pelos doutrinadores que dão conotação negativa ao fenômeno como àqueles pensadores que o defendem. Para estes, o ativismo é, por ora, positivo, e consiste em uma opção sobre a interpretação; é uma postura do magistrado que expande a aplicação da norma especialmente da Constituição - em nome de valores e princípios presentes no ordenamento jurídico brasileiro.

O trabalho distinguiu ativismo de judicialização. Acompanhando, por exemplo, Luís Roberto 
Barroso, a tese considera a judicialização como fenômeno distinto do ativismo. É a expansão de temas passíveis de serem apreciados judicialmente. A origem da judicialização não é a postura do magistrado - como no caso do ativismo mas a vontade do constituinte originário. Esse fenômeno ocorre em quase todo o mundo e tem diversas causas, dentre elas o Estado de Bem-Estar Social e a inflação normativa dele decorrente.

A judicialização da política é, então, decorrência da própria expansão da atividade estatal. No Brasil, outras coisas podem ser apontadas, como a redemocratização (pós-1988), a Constituição altamente abrangente e o controle de constitucionalidade, que permite submeter a grande quantidade de leis produzidas nesse cenário de inflação normativa à apreciação do judiciário. A judicialização intensifica o ativismo judicial, mas não é sua única causa.

Demonstrar que os tribunais, em um caso concreto, extrapolaram suas competências é tarefa trabalhosa. A tese precisou explorar toda a argumentação construída pelos magistrados e compará-la a outra possível, esta sim, contida. Há, portanto, na obra, uma relação imbricada entre o estudo empírico e o dogmático. O segundo acompanha o primeiro, expondo como a interpretação da justiça eleitoral ultrapassou - ou não chegou a ultrapassar - os limites legais. Para evidenciar os momentos ativistas, a tese precisou, então, posicionar-se quanto ao estudo dogmático sobre a competência regulamentar na justiça eleitoral e sobre o tema das decisões analisadas: a "verticalização" das coligações partidárias. 
Esse método de avaliação das decisões expõe premissas do trabalho. Trata-se de estudo juspositivista, embora empírico. Considera que a interpretação e aplicação da lei são operações mentais próximas, mas que não há uma única interpretação correta ou mais correta. Um mesmo texto normativo permite várias interpretações, dentro da "moldura" do texto. É a decisão que fixa a interpretação dentro da moldura.

Os magistrados algumas vezes, tomam decisões selecionando interpretações que extrapolam essa moldura. Isso é o ativismo judicial em sua forma mais simples. Naturalmente, há discussões sobre o que seja essa moldura. A hermenêutica jurídica - sobretudo a constitucional - tem desenvolvido estudos sobre como a interpretação da norma deve ser feita. Métodos - como o sopesamento de princípios (Alexy) - e orientações gerais como a integridade do direito (Dworkin) não faltam. Essa discussão não caberia, contudo, na tese. Como estudo de caso, precisou-se tomar uma posição sobre o ativismo e a juspositiva dogmática (Elival da Silva Ramos) permitia expor como, no mínimo, a postura dos magistrados não é de contida.

O ativismo judicial na Justiça Eleitoral não é exclusividade do caso da verticalização. Ocorre já há muito tempo. O trabalho explica esses outros momentos exacerbados dos magistrados. Talvez até mais ativistas do que a verticalização, os casos da fidelidade partidária, do número de vereadores nas câmaras municipais e da quitação eleitoral inovaram o ordenamento. A verticalização está inserida, então, em quadro maior da postura do Judiciário frente ao processo eleitoral. 
Toda celeuma sobre a verticalização durou anos. Essa é a história contada na tese. Desde 2002 até 2006 o tema passou pelo Judiciário, pelo Legislativo e de volta ao Judiciário. Os magistrados preferem chamá-la de "princípio da coerência nas coligações partidárias". Existia, já em 2002, norma prevendo a coerência - entre eleições majoritárias e proporcionais de uma mesma circunscrição - o que, de início, foi interpretada como rígida. A interpretação evoluiu para uma versão diferente, que permitia combinações nas eleições estaduais, embora ainda orientasse-as pelas nacionais, com exceção dos partidos "solteiros" ou que não participavam da eleição nacional.

o advento da verticalização veio com a interpretação pouco usual de "circunscrição". A simultaneidade das eleições nacionais e estaduais causou uma ilusão nos magistrados: a de que haveria qualquer relação de pertinência entre as circunscrições nacional e estaduais. A circunscrição está ligada a um pleito e não a vários. Em eleições nacionais, há uma circunscrição nacional. Em eleições estaduais, várias (27). Elas existiriam mesmo que os pleitos não fossem simultâneos, como hoje acontece no Brasil. Os magistrados, contudo, criaram uma relação de pertinência: as estaduais estão contidas na nacional. Esse seria o principal motivo para haver a verticalização.

Há vários pontos no mínimo curiosos na interpretação da justiça eleitoral. Curiosamente, a verticalização sempre veio de cima para baixo, nunca de baixo para cima. Curiosamente, também, o mesmo raciocínio não foi usado nas eleições municipais. Essas decisões, ao 
se utilizarem de interpretações expansivas, agiram de modo ativista.

O fato de o ativismo ocorrer na Justiça Eleitoral não é surpresa. A Justiça Eleitoral representa, na doutrina da separação dos Poderes, uma singularidade. O Judiciário exerce competência regulamentar. Não é quando a Justiça Eleitoral exerce essa função - atípica - que o ativismo ocorre. Entendemos que o ativismo é próprio da atividade jurisdicional e não do Poder Judiciário. Editar resoluções que exacerbam a competência seria ultrapassar outro limite, que não o da interpretação. Isso não quer dizer que não tenha havido ativismo.

O ativismo está, justamente, em confundir essas duas competências. Quando O TSE responde uma consulta com um regulamento, está sendo ativista. Quando a interpretação do TSE expande a norma para alterar seu sentido, está sendo ativista. Quando O STF avaliza essas decisões, dá apoio a uma postura ativista do Judiciário. Não é demais dizer que o próprio Barroso considerou a decisão da ADI sobre a verticalização um caso de ativismo.

Por causa da singularidade da Justiça Eleitoral, a contextualização do ativismo em meio aos outros poderes é importante. Tanto Beçak como Barroso e Hirschl insistem que o fenômeno do ativismo deva ser contextualizado com relação aos outros poderes, sua inércia e sua anuência com relação à postura do judiciário. O TSE age quase naturalmente ao confundir as duas competências (regulamentar e jurisdicional) e ser ativista.

A principal questão está na organização dos Poderes (judicialização da política) e na postura dos 
demais Poderes ao não atuarem no tema ou, quando atuam, estão apenas reagindo a algum resultado inconveniente. Essa postura é bastante confortável para eles.

Em inglês existe um ditado "you don't ask turkeys to vote for Christmas". No Brasil, os perus estão muito confortáveis; não é má ideia não ter que decidir sobre o Natal. Quando não gostam, tentam reagir, mas aí pode ser tarde demais.

Por fim, a tese abre-se para potenciais novas pesquisas. Independentemente de adotar-se a definição juspositiva dogmática de ativismo, o caso é, indubitavelmente, pouco contido. A descrição dos argumentos e da evolução dos votos de cada participante do processo decisório permite pesquisas posteriores sobre a interpretação e a argumentação jurídicas. Já a contextualização política permite que o trabalho se expanda para a compreensão da formação do sistema partidário atual. No campo empírico, um próximo passo seria averiguar quais as consequências da atuação do TSE e do STF nas eleições de 2006. Por fim, a dogmática eleitoral pode desenvolver o estudo para formular interpretações das normas atualmente vigentes. 


\section{BIBLIOGRAFIA}

AFONSO DA SILVA, José. Curso de direito constitucional positivo. São Paulo, Malheiros, $33^{a}$ ed. rev. e atual., 2010 .

- Comentário contextual à Constituição. $3^{a}$ ed. São Paulo, Malheiros, 2007.

AFONSO DA SILVA, Luís Virgílio. Sistemas eleitorais: tipos, efeitos jurídicos-políticos e aplicação ao caso brasileiro. São Paulo, Malheiros, 1999.

AGRA, Walber de Moura; CAVALCANTI, Francisco Queiroz. Comentários à nova lei eleitoral: lei n. 12.034, de 29 de setembro de 2009. Rio de Janeiro, Forense, 2009.

AlbUQUeRQue, Afonso de; DIAS, Marcia Ribeiro. "Propaganda política e a construção da imagem partidária no Brasil: considerações preliminares". In: Encontro Anual da Associação Nacional dos Curso de Pós-Graduação em Ciências Sociais (ANPOCS), 26², Caxambu: Anpocs, 2002 (mimeo).

ALMEIDA NETO, Manoel Carlos de. O poder normativo da Justiça Eleitoral. Tese de Doutorado defendida na Faculdade de Direito da Universidade de São Paulo, 2013 .

ARANTES, Rogério Bastos. Judiciário \& politica no Brasil. São Paulo: Idesp: Editora Sumaré, 1997.

BARROSO, Luís Roberto. "Vinte anos da Constituição de 1988: a reconstrução democrática do Brasil". In: Revista de Informação Legislativa, ano 45, n. 179, jul./set. 2008, p. 25-37. 
BARROSO, Luís Roberto. "Judicialização, ativismo judicial e legitimidade democrática". In: Cadernos [SYN] THESIS, v. 5, n. 1, 2012, p. 23-32.

BARROSO, Tiago Aguiar Abreu Portela. "Quitação eleitoral e prestação de contas de campanha: a polêmica interpretação do $\$ 7^{\circ}$, art. 11, da Lei n 9.504/1997". In: Themis - Revista da Escola Superior da Magistratura do Estado do Ceará, v. 8, n. 2, ago/dez 2010, p. 185-194.

BEÇAK, Rubens. Sucessão presidencial de 1955: aspectos políticos e jurídicos. São Paulo: Editora Juarez de Oliveira, 2003.

BEÇAK, Rubens. "A separação dos poderes, o tribunal constitucional e a 'Judicialização da Política'". In: Revista da Faculdade de Direito da Universidade de São Paulo, v. 103, jan./dez. 2008, p. 325-336.

BERNARDI, Renato. "Número de vereadores: Resolução TSE $\mathrm{n}^{\circ}$. 21.702/04 x Leis Orgânicas municipais". In: Boletim de Doutrina ADCOAS, v. 7, n. 18, jul. 2004, p. $285-6$.

BICCA, Carolina Scherer. "Desmistificando o ativismo judicial". In: Direito Público (DPU), n. 46, jul./ago. 2012 , p. 213-226.

BISPO SOBRINHO, José. Comentários à lei orgânica dos partidos políticos. Brasília: Brasília Juridica, 1996.

BRAGA, Cláudio Mendonça. O caráter nacional dos partidos políticos na federação brasileira. Dissertação de Mestrado defendida na Faculdade de Direito da Universidade de São Paulo, 2009. 
CAGGIANO, Monica Herman Salem. Coligações partidfárias: verticalizar ou não-verticalizar?. In: Revista da Faculdade de Direito da Universidade de São Paulo, v . 100,2005, pp. 201- 207 .

CAgGiAno, Monica Herman Salem. "A fenomenologia dos trânsfugas no cenário político-eleitoral brasileiro". In: CAGGIANO, Monica Herman Salem; LEMBO, Cláudio (coord.). O voto nas Américas. Barueri: Manole, 2008, p. 219-253.

CAMPELLO DE SOUZA, Maria do Carmo. Estado e partidos políticos no Brasil (1930 a 1964), $3^{a}$ ed., São Paulo, Alfa-Omega, 1990.

CAMPILONGo, Celso Fernandes. Política, sistema jurídico e decisão judicial. São Paulo: Max Limonad, 2002.

CAMPOS, Sérgio Pompeu de Freitas. Separação dos poderes na jurisprudência do Supremo Tribunal Federal. Porto Alegre: Sergio Antonio Fabris Ed., 2007.

CÂNDIDO, Joel José. Direito eleitoral brasileiro. Bauru, Edipro, $13^{a}$ ed. rev., atual. e ampl., 2008.

CANON, Bradley C. "Defining dimensions of judicial activism". In: Judicature, v. 66, n. 6, dec./jan. 1983, p. 236-247.

CARVALHO, Valter Rodrigues de. Partidos e eleições no Brasil: razões e efeitos da "verticalização" das coligações eleitorais instituído pelo Tribunal Superior Eleitoral. São Paulo, Blucher Acadêmico, 2009 .

CASTRO, José Nilo de; MAYRINK, Cristina Padovani; PRATES, Laura Spyer. "Regulamentação - número de 
vereadores - Lei Orgânica Municipal - possibilidade até realização das convenções partidárias. In: Revista Brasileira de Direito Municipal, ano 10, n. 31, jan./mar. 2009 .

CERQUEIRA, Thales Tácito; CERQUEIRA, Camila Albuquerque. Reformas eleitorais comentadas - Lei n. 12.034/2009 (minirreforma política e eleitoral) e LC n. 135/2010 (ficha limpa). São Paulo: Saraiva, 2010.

CERQUeIRA, Thales Tácito Pontes Luz de Pádua; CERQUeIRA, Camila Medeiros de Albuquerque Pontes Luz de Pádua. Fidelidade partidária \& perda de mandato no Brasil: temas complexos. São Paulo: Premier Máxima, 2008.

CERQUEIRA, Thales Tácito Pontes Luz de Pádua; CERQUEIRA, Camila Medeiros de Albuquerque Pontes Luz de Pádua. "Fidelidade partidária: a insegurança jurídica". In: Revista Jurídica Consulex, ano XI, n. 268, 15.03.2008, p. $30-37$.

CLÈVE, Clemerson Merlin. Fidelidade partidária: estudo de caso. Curitiba: Juruá, 1. ed., 8. tir. 2008.

CONEGLIAN, Olivar. Lei das eleições comentada. Curitiba: Juruá, 2009 , p. 43.

CONTINENTINO, Marcelo Casseb. "Ativismo judicial: considerações críticas em torno do conceito no contexto brasileiro". In: Interesse Público, v. 14, n. 72, mar./abr. 2012, p. 123-55.

CostA, Adriano Soares da. Instituições de direito eleitoral. Belo Horizonte, Del Rey, $6^{a}$ ed., rev., ampl. e atual., 2006. 
CostA, Emília Viotti da. O Supremo Tribunal Federal e a construção da cidadania. São Paulo: Editora UNESP, $2^{a}$ ed. , 2006 .

Couto, Cláudio Gonçalves. As eleições de 2010 e o sistema de partidos no Brasil. In: Interesse Nacional, ano 3, n. 12, jan./mar. 2011, p. 43-51.

CROSS, Frank B.; LINDQUIST, Stefanie A. "Scientific study of judicial activism". In: The Minnesota Law Review, v. 91, 2006.

DELGADO, José Augusto. "A contribuição da Justiça Eleitoral para o aperfeiçoamento da democracia". In: Revista dos Tribunais, n. 718, ago./1995, p. 317-326.

DENARDI JÚNIOR, Adriano. "Prestação de contas de campanha, quitação eleitoral e inelegibilidade". In: Revista de doutrina e jurisprudência - Tribunal Regional Eleitoral de Minas Gerais, n. 18, 2008, p. 917 .

DINIZ, Simone. "As migrações partidárias e o calendário eleitoral". In: Revista de Sociologia e Política, n. 15, nov. 2000, p. 31-47.

FAUSTO, Boris. História do Brasil. São Paulo: Editora da Universidade de São Paulo, 10 ed., 2002.

FIGUEIREDO, Argelina; LIMONGI, Fernando. Executivo e legislativo na nova ordem constitucional. Rio de Janeiro: Editora FGV, 2 ed., 2001.

GERÔNIMO, Gislene Donizetti. "Fidelidade partidária". In: CAGGIANO, Monica Herman Salem; LEMBO, Cláudio (coord.). O voto nas Américas. Barueri: Manole, 2008, p. 107-132. 
GOMES, Marcelo Bolshaw. "A imagem pública de Lula e eleições presidenciais brasileiras (1989/2002). In: I Congresso da COMPOL (Associação Brasileira de Pesquisadores de Comunicação e Política). Salvador: UFBA, 2006.

GOMES, Suzana de Camargo. A Justiça Eleitoral e sua competência. São Paulo: Editora Revista dos Tribunais, 1998 .

GOMES, Suzana de Carvalho. "A competência da Justiça Eleitoral". In: Revista Brasileira de Direito Constitucional, n. 3, jan./jun. 2004, p. 715-721.

GONÇALVES, Luiz Carlos dos Santos. "Sugestões para a reforma do direito eleitoral", In: Revista do Advogado, ano XXX, n. 109, agosto de 2010, p. 61-66.

GREEN, Craig. "An intellectual history of judicial activism". In: Emory Law Journal, n. 01, v. 58, 2009, 1196-1263.

GUERZONI FILHO, Gilberto. "A Justiça eleitoral no Brasil: a desconfiança como elemento fundamental de nosso sistema eleitoral". In: Revista de Informação Legislativa, ano 41, n. 161, jan./mar. 2004, p. 39-45.

GUZMÁN MENDOZA, Carlos Enrique; OLIVEIRA, Ermício Sena de. "Brasil". In: ALCÁNTARA, Manuel; FREIDENBERG, Flavia (coords.). Partidos políticos de América Latina: Cono Sur. México: FCE/IFE, 2003, p. 117-329.

HIRSCHL, Ran. Towards juristocracy: the oriigins and consequences of the neoconstitutionalism. Cambridge, Harvard University Press, 2004. 
JARDIM, Torquato. Direito eleitoral positivo. Brasília: Brasília Jurídica, 2. ed., 1998.

KMIEC, Keenan D. "The origin and current meaning of 'judicial activism"".In: California Law Review, v. 92, 2004 .

KINZO, Maria D’Alva Gil. Radiografia do quadro partidário brasileiro. Rio de Janeiro, Fundação Konrad Adenauer, 1993.

KRAUSE, Silvana; SCHMITT, Rogério (orgs.). Partidos e coligações eleitorais no Brasil. Rio de Janeiro, Fundação Konrad Adenauer; São Paulo, Editora da Unesp, 2005 .

KRAUSE, Silvana; DANTAS, Humberto; MIGUEL, Luis Felipe. Coligações partidárias na nova democracia brasileira: perfis e tendências. Rio de Janeiro, Fundação Konrad Adenauer; São Paulo, Editora da Unesp, 2010.

LEAL, Roger Stiefelmann. O efeito vinculante na jurisdição constitucional. São Paulo: Saraiva, 2006.

LEMBO, Cláudio. "Cronologia básica do direito eleitoral brasileiro". In: CAGGIANO, Monica Herman Salem; LEMBO, Cláudio (coords.). O voto nas Américas. Barueri: Manole, 2008, p. 73-106.

LEWANDOWSKI, Ricardo. "Fidelidade partidária". In: Revista do Advogado, ano Xxx, n. 109, agosto de 2010, p. $7-10$.

LINS, Eloy d'Almeida. "Fontes materiais e formais do direito: organização e funcionamento da Justiça Eleitoral; e cláusula de barreira legal". In: Revista 
ESMAFE - Escola de Magistratura Federal da $5^{a}$ Região, n. 11,2006, p. 77-97.

LÓSSIO, Luciana. "Infidelidade partidária para os cargos majoritários - análise de um caso concreto". In: Revista Brasileira de Direito Eleitoral, ano 2, n. 3, jul. 2010 .

LUCON, Paulo Henrique dos Santos; VIGLIAR, José Marcelo Menezes. Código eleitoral interpretado: normas eleitorais complementares. São Paulo, Atlas, $2^{a}$ ed., 2011.

MAINWARING, Scott P. Sistemas partidários em novas democracias: o caso do Brasil. Trad. port. Vera Pereira. Porto Alegre, Mercado Aberto; Rio de Janeiro, FGV， 2001 .

MAINWARING, Scott P.; SCULLY, Timothy R. (eds.) Building democratic institutions: party systems in Latin America. Stanford, Stanford University Press, 1995.

MELLO FILHO, José Celso de. "O Supremo Tribunal Federal na Constituição de 1988: espaço de construção de uma jurisprudência de liberdades". In: BRASIL. Supremo Tribunal Federal (STF). A Constituição de 1988 na visão dos Ministros do Supremo Tribunal Federal. Brasília: Secretaria de Documentação/STF, 2013, p. 1760 .

MELO, Carlos Ranulfo. "Nem tanto ao mar, nem tanto a terra: elementos para uma análise do sistema partidário brasileiro". In: MELO Carlos Ranulfo; SÁEZ, Manuel Alcántara (orgs.). A democracia brasileira: balanços e perspectivas para o século 21. Belo Horizonte, Editora UEMG, 2007, p. 267-302. 
MELO, Carlos Ranulfo. "Migração partidária na Câmara dos Deputados: causas, consequências e possíveis soluções". In: BENEVIDES, Maria Victoria; VANNUCHI, Paulo; KERCHE, Fábio (orgs.). Reforma política e cidadania. São Paulo: Fundação Perseu Abramo. 2003, p. $321-343$.

MELO, Carlos Ranulfo. Retirando as cadeiras do lugar: migração partidária na Câmara dos Deputados (19852002). Belo Horizonte: Editora da UFMG, 2002.

MELO FRANCO, Afonso Arinos de. História e teoria dos partidos políticos no Brasil. $3^{a}$ ed., São Paulo, AlfaOmega, 1974.

MENDES, Gilmar; BRANCO, Paulo Gustavo Gonet. Curso de direito constitucional. São Paulo, Saraiva, $8^{a}$ ed. rev. e atual, 2013.

MENDES, Gilmar. "A atividade normativa da Justiça Eleitoral no Brasil". In: CostA, Marcio A. Mendes. Direito e democracia: debates sobre reforma política e eleições. Rio de Janeiro: EJE/TRE-RJ, 2008, p. 51-56.

MEZZAROBA, Orides. Partidos políticos: princípios e garantias constitucionais. Lei 9.096/95. Anotações jurisprudenciais. Curitiba: Juruá, 2008.

MIGUEL, Luis Felipe. "Discursos cruzados: telenotícias, HPEG e a construção da agenda eleitoral". In: Sociologias, ano 6, n. 11, jan./jun. 2004, p. 238-245.

NICOLAU, Jairo Marconi. Sistemas eleitorais: uma introdução. $4^{\text {a }}$ ed., Rio de Janeiro, FGV, 2002.

NICOLAU, Jairo Marconi. Notas sobre as eleições de 2002 e 0 sistema partidário brasileiro. In: Wilhelm 
Hofmeister. Cadernos Adenauer: Eleições e partidos. Ano IV, n. 01, 2003.

OLIVEIRA, Fabiana Luci de. Justiça, profissionalismo e política: o STF e o controle de constitucionalidade das leis no Brasil. Rio de Janeiro: Editora FGV, 2011.

PAGANELLI, Celso Jefferson Messias; IGNÁCIO JUNIOR, José Antonio Gomes. "Ativismo judicial nas resoluções da Justiça Eleitoral - duvidosa compatibilidade do artigo 23, IX e XVIII do Código Eleitoral com a Constituição Federal". In: Anais do XX Congresso Nacional do CONPEDI realizado em Vitória/ES. Florianópolis: Fundação Boiteux, 2012, p. 4153-4178.

PEDRA, Adriano Sant'Ana. "A construção judicial da fidelidade partidária no Brasil". Revista Brasileira de Estudos Constitucionais - RBEC, ano 2, n. 6, abr. 2008 .

PELICIOLI, Angela Cristina. "O Supremo Tribunal Federal como legislador positivo: o caso da fidelidade partidária". In: Boletim de Direito Administrativo, ano XXIV, n. 11, nov. 2008, p. 1259-1275.

PEREIRA, Rodolfo Viana. "Contencioso eleitoral: polissemia conceitual, sistemas comparados e posição brasileira". In: Anais do XX Congresso Nacional do CONPEDI realizado em VitórialES. Florianópolis: Fundação Boiteux, 2012, p. 4207-4235.

PIMENTA JÚNIOR, Luciano Caleiro. Desaprovação de contas de campanha e a 'perda' do cargo eletivo. In: Revista de doutrina e jurisprudência - Tribunal Regional Eleitoral de Minas Gerais, n. 20, 2010, p. 57-62. 
PIZzolAtTI, Rômulo. "A natureza das atividades da Justiça Eleitoral". In: Resenha Eleitoral - nova série - TRE/SC, v.4, n.1, jan./jun. 1997, p. 25-34.

PONTE, Antonio Carlos da. Crimes eleitorais. São Paulo: Saraiva, 2008 .

RAMOS, Elival da Silva. Ativismo judicial: parâmetros dogmáticos. São Paulo, Saraiva, 2010.

REIS, Daniel Gustavo Falcão Pimentel dos. Verticalização das coligações partidárias: melhor caminho para a coerência político-eleitoral? Disponível em: http://www.sbdp.org.br/artigos_ver.php?idConteudo=42 . Acesso em 11. 10. 2010.

REIS, Daniel Gustavo Falcão Pimentel dos; MACEDO, Rafael Rocha de. "Os partidos políticos e as campanhas eleitorais brasileiras: sistema normativo, propostas de reforma legislativa e as recentes decisões do Supremo Tribunal Federal". In: CAGGIANO, Monica Herman Salem (org.), Comportamento eleitoral, Barueri, Manole, 2010, p. 161-190.

REIS, Daniel Gustavo Falcão Pimentel dos. Financiamento da política no Brasil. Dissertação de Mestrado defendida na Faculdade de Direito da Universidade de São Paulo, 2010.

RIBEIRO, Renato Ventura. Lei eleitoral comentada. São Paulo: Quartier Latin, 2006.

RODRIGUES, Fernando. Políticos do Brasil. São Paulo, Publifolha, 2006.

RONDELLI, Elizabeth; WEBER, Maria Helena. "Ensaio das eliminatórias: os media e o campeonato eleitoral", In: 
Comunicação \& Política, n. 1, ago./nov. 1994, p. 4152 .

ROLLO, Alberto (org.). Eleições no direito brasileiro: atualizado com a Lei no 12.034/09. São Paulo, Atlas, 2010 .

ROSAS, Roberto. "O sucesso da Justiça Eleitoral", In: Revista do Instituto dos Advogados de São Paulo, n. 2, p. 137-142.

SADEK, Maria Tereza. A Justiça Eleitoral e a consolidação da democracia no Brasil. São Paulo: Fundação Konrad Adenauer, 1995.

SCHMITT, Rogério. Partidos políticos no Brasil (19452000). Rio de Janeiro: Jorge Zahar Ed., 2000.

SCHNAID NETO, David. "A consequência da alteração do conceito de quitação eleitoral para candidatos com contas de campanha desaprovadas". In: Paraná Eleitoral, n. 73, 2010, p. 95-105.

SILVA, Eduardo Silva da. "Jurisdição e positivismo jurídico: breves reflexões sobre o procedimento de consulta na Justiça Eleitoral". In: Revista Forense, v. 350, abr./mai./jun. 2000, p. 429-440.

Veluoso, Carlos Mário da Silva; AGRA, Walber de Moura. Elementos de direito eleitoral. São Paulo: Saraiva, 2009 .

VIEIRA, Oscar Vilhena. Supremo Tribunal Federal: jurisprudência política. $2^{a}$ ed., São Paulo, Malheiros, 2002 .

VIEIRA, Tarcisio. "Experiencias nacionales representativas: Brasil". In: ZOVATTO, Daniel et.all 
(coord.). Dinero y contienda político-electoral: reto de la democracia. México: Fondo de Cultura Económica, 2003, p. 425-434. 